
EDUARDO M ODENESE FILHO

\section{ENTRE UNHAS E CURVAS:}

A TEORIA E A PRÁTICA NA OBRA DE ZENON LOTUFO

DISSERTAÇÃO DE MESTRADO APRESENTADA À

FACULDADE DE ARQUITETURA E URBANISM O DA

UNIVERSIDADE DE SÃO PAULO, PARA OBTENÇÃO

DO TÍTULO DE M ESTRE EM ARQUITETURA E URBANISM O

ÁREA DE CONCENTRAÇÃO: PROJETO DE ARQUITETURA

ORIENTADOR: LÚCIO GOM ES M ACHADO

SÃO PAULO, 2008 
AUTORIZO A REPRODUÇÃO E DIVULGAÇÃO TOTAL OU PARCIAL DESTE TRABALHO, POR QUALQUER M EIO CONVENCIONAL OU ELETRÔNICO, PARA FINS DE ESTUDO E PESQUISA, DESDE QUE CITADA A FONTE.

E-MAIL: modenesefilho@uol.com.br

Modenese Filho, Eduardo
M 689e $\quad$ Entre linhas e curvas: a teoria e a prática na obra de Zenon
Lotufo / Eduardo M odenese Filho. -São Paulo, 2008.
199 p : il.
Dissertação (M estrado - Área de Concentração: Projeto de
Arquitetura) - FAUUSP.
Orientador: Lúcio Gomes M achado
1. Arquitetura moderna - Brasil 2. Arquitetura - Teoria 3. Lotufo,
Zenon I.Título
CDU 72.036(81)


À meus pais, que me ensinaram a traçar retas e curvas. 
Agradeço ao meu orientador Lúcio Gomes M achado, por indicar alguns caminhos.

Aos professores que participaram da minha banca de qualificação: Fernanda Fernandes e Miguel A. Buzzar, pelos comentários construtivos.

E também, aos professores Luis Antonio Jorge, Hugo Segawa, Carlos Lemos, Jon Maitejean, Walter Maffei, Eugênio H. Monteferrante pelas entrevistas e palavras de apoio.

À família de Zenon Lotufo, em especial Dona Coraly, Vitor, Cristina e Tomaz, pela credibilidade depositada. Aos meus familiares e amigos, pela confiança e incentivo. À Prefeitura M unicipal de Botucatu, pela documentação fornecida. Às funcionárias da Biblioteca da FAUUSP e EPUSP, pela atenção dispensada.

À Flávia Carmoni, pelo carinho e presença. 
O foco deste trabalho é a relação entre teoria e prática na trajetória profissional do arquiteto paulista Zenon Lotufo (1911-1985) destacando fatos marcantes que pontuaram um quadro evolutivo pessoal inserido em determinado contexto histórico. Período este onde a arquitetura moderna brasileira despontou e se consolidou. Fatos como sua formação acadêmica no curso de Engenheiro-Arquiteto na Escola Politécnica de São Paulo (33-36) e a influência didática de Luis Anhaia Mello dão origem a esse itinerário. Os contatos com a chamada "escola carioca" através de trabalhos realizados com Abelardo de Souza e Hélio Duarte (46-48) e com Oscar Niemeyer no projeto para o Parque do Ibirapuera (51-54) complementam seu repertório moderno. Por sua vez, sua experiência como professor da então recém fundada Faculdade de Arquitetura e Urbanismo (48) culmina com o polêmico Concurso de Cátedra (57). E finalmente, este percurso se encerra numa fase de produção madura (5877), apoiada nas características do chamado "brutalismo paulista". 
The focus of this work is the relationship between theory and practice in the professional career of the architect Zenon Lotufo (1911-1985) pointing out remarkable facts that determined a personal evolving picture in a certain historical context. A period when the Brazilian modern architecture began to appear and consolidated. Facts as his academic formation in the Engineer-Architect course at the Escola Politécnica de São Paulo (33-36) and the influence of Professor Luis Anhaia M ello give origin to this itinerary. The contacts with Abelardo de Souza and Hélio Duarte (46-48) and with Oscar Niemeyer in the project of the Ibirapuera Park (51-54) complement his modern repertory. His experience as a professor at the new founded Faculty of Archictecture and Urbanism (48) culminates with the polemic Chair Exam (57). And finally this route closes down in a mature production phase (58-77), based on the characteristics of the so called "paulista brutalism". 


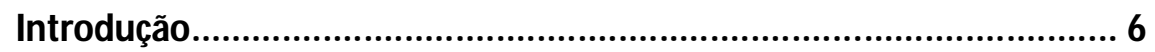

Capítulo 1 - Anos de formação (31-46) ......................................19

Capítulo 2 - Afirmação moderna e escola carioca (46-58) .................. 61

Capítulo 3 - Brutalismo e maturidade (58-85) ............................... 126

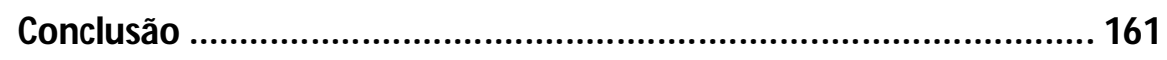

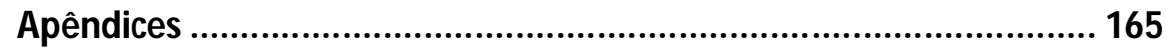

Bibliografia ............................................................................ 193 
"Caminante no hay camino, se hace camino al andar...". ${ }^{1}$

Esta dissertação de mestrado trata da revisão crítica da obra do engenheiro-arquiteto paulista Zenon Lotufo (1911-1985) sob o ponto de vista da interlocução entre teoria e prática em sua atividade profissional, dentro de um quadro de questões pertinentes à sua época e à disciplina arquitetônica.

Isto é, versa e refletem sobre os aspectos da relação entre sua formação acadêmica, bem como sua experiência didática como professor, e o exercício do projeto arquitetônico dentro de um contexto histórico e cultural.

Assim, o objetivo principal deste trabalho não foi analisar os projetos encontrados do arquiteto Zenon Lotufo, mas sim introduzí-los dentro de um panorama (contexto espaço-temporal) em que ocorreram. E também no que diz respeito às questões específicas do conjunto de idéias e

\footnotetext{
${ }^{1}$ Trecho extraído do poema Cantares de Antonio M achado (1875-1939), poeta espanhol.
} 
conceitos defendidos pelo arquiteto e suas aplicações, entendendo-os como se apresentaram nas diferentes fases de sua atuação.

Para isto, adotamos alguns períodos temáticos capazes de identificar algumas relações dentro da sua trajetória (que serão justificados a partir do capítulo 1) que basicamente foram subdivididos em: Anos de formação (31-46), Escola carioca e afirmação moderna (46-58) e Brutalismo e maturidade (58-85).

Buscamos ainda em primeiro plano, trazer à tona o reconhecimento acadêmico da produção de um importante nome da arquitetura moderna brasileira que juntamente com Osvaldo Bratke, Vilanova Artigas, Rino Levi e Oscar Niemeyer, entre outros, difundiram os novos padrões estéticos em meados dos anos 30 e 40. E que, no entanto, apesar de ter realizado inúmeros trabalhos e ter tido uma dedicação didática intensa, a comunidade e a historiografia arquitetônica brasileira deram pouco valor à sua contribuição profissional.

Em resumo, buscamos resgatar o legado de idéias e projetos deixados por Zenon, entendidos também como sentido de uma trajetória pessoal, fruto de escolhas e acasos que ora marcam seqüências, a "linha reta" do engenheiro (construtor), e também as mudanças, a "linha curva" do arquiteto (artista) na vida do paulista, visando reconstituir suas origens e permanência nos dias atuais.
Suas principais reflexões sobre a disciplina arquitetônica, bem como sua produção, são o resultado dessa trajetória particular marcada por personalidades e contatos, encontros e obstáculos, desvios e concordâncias, mas em que sempre preponderaram simplicidade, equilíbrio e caráter profissional, como veremos.

\section{Entre linhas e curvas}

A escolha do título deste trabalho deriva das influências que cercaram a carreira profissional de Zenon Lotufo, onde procuramos imaginar que as linhas retas seriam a racionalidade técnica e construtiva, herdadas da Escola Politécnica de São Paulo, que teriam originado o termo "escola paulista", e as linhas curvas simbolizariam a plástica formal e livre da "escola carioca", herdadas principalmente pelo contato com Oscar Niemeyer e Abelardo de Souza, entre outros, com quem Zenon trabalhou. Zenon Lotufo também foi grande admirador das idéias e do trabalho de Le Corbusier, fato comprovado em seus textos, e também, pela influência de Oscar Niemeyer, na rica experiência do projeto para o parque Ibirapuera. De tal modo que podemos observar em algumas obras que Zenon Lotufo procurou conciliar o uso de linhas retas (marca da racionalidade corbusiana) com linhas curvas (herança do contato com a escola carioca) em suas composições volumétricas. 
Le Corbusier dizia que a linha reta é a linha da vida na cidade moderna, uma resposta precisa a uma demanda, um ato voluntário e consciente, é a linha do homem; em contraposição, o caminho em curvas seria arbitrário, fruto do acaso e do descuido instintivo, para ele, a linha do asno. Em função da economia, uma obra moderna exigiria o emprego da reta; para Corbusier, a reta era a grande aquisição da arquitetura moderna.

Por sua vez, Oscar Niemeyer diz que: "Não é o ângulo reto que me atrai, nem a linha reta, dura, inflexível, criada pelo homem. 0 que me atrai é a curva livre e sensual, a curva que encontro nas montanhas do meu país, no curso sinuoso dos seus rios, nas ondas do mar, no corpo da mulher preferida. De curvas é feito todo o universo, o universo curvo de Einstein." ${ }^{2}$

\section{A questão da crítica}

A noção de revisão crítica refere-se à capacidade de se perceber e julgar determinado assunto ou tema, de posse dos conhecimentos necessários. Trata-se de certa maneira de pensar e agir na relação com o que existe, 0 que se sabe e o que se faz numa determinada cultura e sociedade, constituindo-se, portanto, um instrumento para se alcançar uma verdade ou uma virtude.

\footnotetext{
${ }^{2}$ Underwood, David. “Oscar Niemeyer e o modernismo de formas livres no Brasil”. Cosac \& Naify, São Paulo, 2002, p. 142.
}

Assim, criticar é fazer juízo através do ato psicológico de se contrapor, baseando-se num conhecimento prévio, tornando-se trabalho intelectual que visa explicitar um pensamento e encontrar novos consentimentos.

“Para se criticar algo, é necessário conhecer a matéria em análise, fazendo-se juízo acerca de seu valor enquanto objeto intelectual, sem pré-conceitos ou pré-juízos, questionando o que são as coisas, os fatos e as idéias. Trata-se de uma atitude fundamental no processo de constituição do pensamento humano, pois nos permite distinguir o verdadeiro do falso, o real do imaginário e 0 certo do verossímil." 3

No entanto, procuramos ao longo deste trabalho justapor as principais realizações do arquiteto Zenon Lotufo seja teórico ou práticas, de modo a construir um quadro comparativo-cronológico que possibilite um aprofundamento crítico de sua obra.

${ }^{3}$ FOUCALT, M ichel. O que é a crítica? (Qu'est-ce que la critique?)Bulletin de la Société française de philosophie, Vol. 82, no 2, pp. 35 - 63, avr/juin 1990 (Conferência proferida em 27 de maio de 1978). Tradução de Gabriela Lafetá Borges e revisão de Wanderson Flor do Nascimento.

বhttp://www.unb.br/fe/tef/filoesco/foucault/critique.html> 


\section{Sobre as noções de teoria e prática}

Investigar a correspondência e coerência entre as idéias (valores) e realizações (ações) do arquiteto Zenon Lotufo remete-nos também a uma pequena especulação sobre as noções de teoria e prática.

Entendemos neste trabalho, teoria como sistema organizado de idéias e conceitos que procuram explicar fenômenos podendo ser provados por meio de experiências reprodutíveis, ou seja, práticas. A teoria justifica o fato, mas não é o fato em si, é sim construída a partir da ocorrência deste fato.

Quanto à prática, como dissemos, é a justificativa real e concreta para a teoria. Assim, a teoria só é considerada como tal se foi comprovada pela prática. Ou seja, não existe teoria sem prática.

Em outras palavras, podemos também dizer que a teoria trata da reflexão (pensar) a partir da ação (agir). Conseqüentemente, a prática corresponde ao agir, a partir do pensar.

Em se tratando da disciplina arquitetônica podemos imaginar a partir disso algumas questões no sentido de explorar a relação entre teoria e prática na trajetória profissional de Zenon Lotufo. Por exemplo, qual a proximidade entre os valores teóricos da arquitetura e os procedimentos reais que produzem sua obra? Sua prática arquitetônica é determinada pelos valores teóricos ou acadêmicos, ou pelas regras do cliente e do mercado? Qual o espaço para experimentação original e legítima do arquiteto? E da cópia e imitação?

Talvez estes domínios estejam todos interligados em um emaranhado difuso e seja difícil de medir com precisão o quanto um acaba determinando e interferindo no outro. No entanto, procuramos abordálos de modo integrado como partes constituintes de um todo maior: 0 percurso profissional de Zenon Lotufo.

O intuito de polarizar os conceitos "teoria" e "prática" dentro de uma visão crítica da trajetória do arquiteto visa relacionar ambos, de modo que a teoria torna-se a reflexão que se faz sobre a ação (prática) do projeto de arquitetura, e vice-versa, num processo que se retroalimenta continuamente.

\section{Revisão permanente}

Sabemos que os protagonistas do movimento moderno na arquitetura brasileira costumam concentrar-se usualmente em torno de nomes como Lúcio Costa, Oscar Niemeyer, Vilanova Artigas, Lina Bo Bardi e mais alguns outros poucos.

No entanto, é fundamental revermos o peso e a contribuição de cada um deles para a historiografia periodicamente, de modo a trazer à tona certos vazios deixados para trás, ou ainda se preferirmos, personagens esquecidos ao longo destes percursos. 
Sem dúvida, o engenheiro-arquiteto Zenon Lotufo se encaixaria num desses casos, onde os registros historiográficos acabaram passando sem reconhecer seu devido valor e relevância para a cultura arquitetônica paulista ou se preferirmos até, nacional.

\section{Proximidade do objeto}

A escolha do tema se deu num inesperado (e feliz) encontro com o nome de Zenon Lotufo no livro Arquitetos da Poli, de Silvia Ficher, onde a autora registrou (em forma de fichários) os formados pelo curso de EngenheiroArquiteto da Escola Politécnica de São Paulo.

Uma vez também que este pesquisador é da mesma cidade de Zenon Lotufo, o município paulista Botucatu, que aparecia como local de nascimento e também falecimento na ficha do livro. M eu espanto e orgulho foram confirmar que um importante arquiteto moderno pertenceu a minha terra natal e que havia participado decisivamente em alguns dos principais episódios da arquitetura paulista do século XX.

A facilidade e proximidade de contato com a família Lotufo (que mantêm ainda hoje propriedade nos limites da área rural e urbana e onde vivem ainda hoje Dona Coraly, esposa de Zenon, aos 88 anos de idade) possibilitou 0 acesso às informações e documentos, como fotos, escritos, publicações de época, além de uma série de depoimentos, que foram determinantes para o desenvolvimento deste trabalho.
Apesar desta proximidade, houve grande dificuldade em encontrar os arquivos originais do arquiteto como desenhos, plantas, mapas, croquis, uma vez que, segundo Coraly, Zenon não tinha o hábito de preservá-los.

“Ele jogava tudo fora, como quem diz: isto daqui é passado, não tem importância, vamos em frente". ${ }^{4}$

Mesmo assim, localizamos uma quantidade considerável de projetos (mais de sessenta) publicados principalmente nas revistas Acrópole, Módulo e Habitat. Outro fato que chamou nossa atenção foi a diversidade de programas enfrentados pelo arquiteto, indo desde residências a plano diretores, passando por igrejas, edifícios escolares, administrativos, institucionais, clubes recreativos, entre outros.

E também destacamos que a maior parte dos projetos foi realizada para 0 cliente público como prefeituras municipais, órgãos federais e estaduais, além de vários concursos nacionais que Zenon venceu fato que também traduz o significado e a relevância de sua obra.

\section{A trajetória de um arquiteto e a construção de sua história}

Importante lembrar que a história não se faz sem historiador, e conseqüentemente, é ele quem preenche as lacunas e os vazios entre os documentos. Portanto, as interpretações encontradas ao longo deste

\footnotetext{
${ }^{4}$ Depoimento de Coraly Lotufo em Botucatu, 25 de setembro de 2006.
} 
trabalho (falhas ou incompletas, e mesmo superficiais) fazem parte de uma visão pessoal de conjunto cuja responsabilidade pertence a nós.

Sigfried Giedion em Espaço, Tempo e Arquitetura afirma que o historiador deve manter uma proximidade íntima com as questões de sua época, somente assim, seria capaz de encontrar heranças esquecidas do passado.

"A história não é um simples repositório de fatos imutáveis, mas um processo, um conjunto de posturas e interpretações vivas e mutáveis. Voltar-se para uma época passada não significa apenas examiná-la e encontrar um padrão para todos que a visitam. 0 olhar retrospectivo transforma seu objeto. Referências absolutas não existem para 0 historiador. A história não pode ser tocada sem que seja modificada" ${ }^{5}$

No conhecido texto Sobre o conceito de história ${ }^{6}$ de Walter Benjamin, 0 autor afirmou que "articular historicamente o passado, não significa conhecê-lo como ele foi. Significa apropriar-se de uma reminiscência tal como ela relampeja no momento de perigo. Este perigo ameaça tanto a tradição como os que a recebem".

Segundo Benjamin, em cada época, é preciso arrancar a tradição do conformismo que quer apoderar-se dela. Apenas quem tem o dom para

\footnotetext{
${ }^{5}$ Giedion, S. Espaço, tempo e arquitetura. (original - 1941) M artins Fontes, São Paulo, 2004, pgs. 32-33.

${ }^{6}$ Walter Benjamin -- Obras escolhidas. Vol. 1. Magia e técnica, arte e política. Ensaios sobre literatura e história da cultura. Prefácio de Jeanne Marie Gagnebin. São Paulo: Brasiliense, 1987, p. 222-232.
}

despertar os lampejos de esperança do passado é a figura do historiador, convencido de que também os mortos não estarão em segurança se 0 conformismo vencer.

Porém, repetidamente, o historiador acaba estabelecendo uma relação de empatia com os vencedores. E por sua vez, a empatia com os vencedores beneficia sempre os dominadores, que são herdeiros dos que venceram antes.

Portanto, para Benjamin, a tarefa do historiador deve traduzir-se em luta contra as convenções, na busca de outra leitura do passado que contemple a procura pelos não-ditos e excluídos. Trata-se de um ataque frontal às concepções lineares e conformistas da história, dessa noção positivista do progresso e da historiografia dos acontecimentos.

Benjamin acreditava que o historiador é capaz de identificar no passado os germes de outra história, capaz de levar em consideração os sofrimentos acumulados e dar nova face às esperanças frustradas. Assim, deve-se construir uma experiência com o passado e não fixá-lo como um conhecimento objetivo. Eis a arte da narração.

Para o filosófo, a história não seria algo estático, mas sim dinâmico, onde era preciso revê-la e reavaliá-la para não deixá-la nas mãos do conformismo. Desta forma, nos parece mais uma vez justificado aqui a pesquisa em torno da trajetória profissional de Zenon Lotufo. 


\section{Arquitetura moderna}

Outra questão importante é a construção de uma nova história que permita identificar a riqueza, complexidade, limites e contradições da arquitetura moderna, uma vez que esta tornou-se (segundo alguns autores e teóricos) uma das principais vilãs, responsável pela decadência da cidade contemporânea.

Se há algum sentido em pensar atualmente na permanência do movimento moderno hoje, este estaria numa visão e atitude frente ao mundo (como por exemplo, Le Corbusier que buscava desenvolver uma arquitetura do seu tempo, capaz de possibilitar um retorno à natureza e ao mesmo tempo, emocionar as futuras gerações), e não apenas à reprodução de um repertório formal.

Por sua vez, Hélio Piñon discute em seu livro Teoria do Projeto ${ }^{7}$ que 0 modo de conceber (projetar) dos modernos era distinto do classicismo acadêmico no sentido do enfoque aos problemas construtivos, ou seja, muito mais apoiado no aspecto científico do que no mimético ou tipológico. Assim, o arquiteto registrava o progresso e a arquitetura era testemunho físico da história.

Para Piñon, não se pode apenas reduzir o modernismo em arquitetura a um conjunto de características formais e plásticas ou preceitos morais e ideológicos. Deve-se reconhecê-lo principalmente como modo de

${ }_{7}^{7}$ Piñon, Hélio. Teoria do projeto. Livraria do Arquiteto, Porto Alegre, 2006. enfrentar e resolver o problema de sua construção enquanto síntese entre função, ordem, clareza e economia. Isto parece-nos a grande herança moderna, corretamente aplicada e deixada por arquitetos como Zenon Lotufo, e talvez ainda hoje, o modo mais eficaz de se enfrentar o projeto arquitetônico.

\section{Estrutura e conteúdo dos capítulos}

0 trabalho teve como propósito organizar os principais projetos realizados pelo engenheiro-arquiteto Zenon Lotufo, de modo a sistematizá-los em três fases de características distintas: Fase 1 - Anos de formação (31-46), Fase 2 - Escola carioca e afirmação moderna (46-57) e Fase 3 - Maturidade e brutalismo (58-85).

A primeira fase que convencionamos de "Anos de formação" de 1931 a 1946, esteve marcada principalmente por: sua formação universitária no curso de engenheiro-arquiteto na Escola Politécnica da Universidade de São Paulo (33-36) envolvendo o contato com excelentes professores como Luis Ignácio de Anhaia M ello, sendo seu assistente por duas ocasiões (38 e 47); os primeiros trabalhos com o colega Afonso lervolino como o Paço M unicipal de Taquaritinga (37) e o M ercado M unicipal de Sorocaba (37-38); a experiência na administração pública de Santos como Diretor da secretaria de Obras (39-45) e finalmente, prefeito da Estância de Campos do J ordão em 46. 
Quanto às características formais e técnicas arquitetônicas, predominaram neste período o início das composições mais limpas, com controle dos ornamentos nas fachadas, volumes mais puros e uso ainda tímido do concreto armado nas estruturas.

A segunda fase, "Escola carioca e afirmação moderna" de 1946 a 1957, ficou definida basicamente pela parceria com Abelardo de Souza e Hélio Duarte (46-49), representantes diretos da Escola Nacional de Belas Artes do Rio de Janeiro, ambos formados na época da reforma curricular de Lúcio Costa; experiência com Oscar Niemeyer na realização dos pavilhões de exposição do Parque do Ibirapuera por ocasião do IV Centenário da cidade de São Paulo (51-55); e pelo ensino didático como professor catedrático do curso Composição de Arquitetura, na Faculdade de Arquitetura e Urbanismo (FAUUSP), recém inaugurada, passagem conturbada (49-57) que terminou de modo desastroso com a reprovação no polêmico Concurso de Cátedra.

Nesta ocasião, escreveu o ensaio "O espaço psicológico na Arquitetura", premiado pelo Conselho Regional de Engenharia e Arquitetura, onde descreve a importância dos aspectos psicológicos na organização do espaço arquitetônico.

A arquitetura praticada nesta fase apropriou-se da linguagem mais livre e sensual da escola carioca, com o predomínio de linhas mais curvas,

abóbadas e marquises de concreto armado, uso dos pilotis, continuidade espacial garantida pela transparência dos grandes panos de vidro, modulação racional das estruturas e dos vãos, entre outros elementos que fortaleceram a afirmação da arquitetura moderna brasileira.

É a fase de maior volume de trabalho para Zenon Lotufo, com mais de 40 projetos publicados em periódicos incluindo internacionais como a revista americana Archicteture Review.

Sua última fase, "Maturidade e brutalismo" de 1958 a 1985, marcou-se pela parceria com Ubirajara Ribeiro (58-65), e em seguida com seu filho Vitor Amaral Lotufo (67-73), tendo vencido vários concursos nacionais importantes e realizado grandes projetos institucionais e públicos, como mostraremos a diante.

Entre as características que definiam as concepções formais e arquitetônicas estavam: o uso do concerto armado aparente, soluções volumétricas mais simples, esquema estrutural legível nas elevações, ausência de acabamentos e revestimentos mostrando 0 aspecto autêntico dos materiais de construção.

Em termos didáticos, Zenon ausentou-se da academia por quase 10 anos em virtude da frustração com a FAUUSP, pela anulação do Concurso de Cátedra em 1957, retornando à Escola Politécnica apenas em 66.

Nesta ocasião, apresentou o ensaio "Arte ou artifício" onde descreve sucintamente a relação entre forma e estrutura ao longo da história da arquitetura ocidental, desde a Grécia Antiga até o movimento moderno. 
Em 80, aposentou-se como auxiliar de ensino na FAUUSP, retornando à sua cidade natal Botucatu, onde comprou um sítio para passar os últimos anos ao lado de sua família.

\section{Breve biografia}

Zenon Lotufo nasceu na cidade de Botucatu, interior do Estado de São Paulo, em 27 de dezembro de 1911. Filho de imigrantes italianos, sua educação foi marcada pela religião presbiteriana, mas sempre esteve vinculada a ensinamentos artísticos e culturais (música, línguas, literatura).

Seu pai, Reverendo Francisco Lotufo (1865-1946), era pastor protestante que havia realizado seus estudos preparatórios no instituto M ackenzie na cidade de São Paulo, tendo sido ordenado em 1896. Veio trabalhar no município de Botucatu, onde foi licenciado e exerceu todo seu ministério. Dessa maneira, a religião foi fator determinante na educação de Zenon tanto que definiu importantes aspectos de sua personalidade como introspecção, humildade, caráter e honestidade.

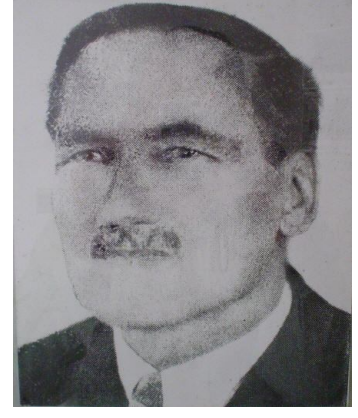

Fig. 1: Francisco Lotufo (Fonte: www.mackenzie.br)

No início dos anos 30, Zenon foi admitido na Escola Politécnica do Rio de Janeiro (1931), mas transferiu-se para o curso de Engenheiro Civil da Politécnica de São Paulo em 1933, passando no ano seguinte para o curso de Engenheiro-Arquiteto, o qual conclui em $1936 .{ }^{8}$

Sua formação acadêmica foi um tanto peculiar, considerando que foi 0 único aluno da sua turma. Naquela época, o curso de EngenheiroArquiteto na Escola Politécnica da Universidade de São Paulo era bastante exíguo (com poucos alunos) e distinguia-se basicamente pelas aulas de Composição de Arquitetura, ministradas por Luis Ignácio de Anhaia M ello. Anhaia M ello nasceu em São Paulo em 1891. Entrou para o primeiro ano do curso geral da Politécnica em 1909 e diplomou-se como Engenheiro-

\footnotetext{
${ }^{8}$ FICHER, Sylvia. Os arquitetos da Poli: Ensino e Profissão em São Paulo. São Paulo, EDUSP, 2005.
} 
Arquiteto em 1913. Recém-formado, entrou para o escritório de Ramos de Azevedo, mas dedicou-se pouco à arquitetura.

Sua principal atuação foi à docência. Efetivado em 1926, como catedrático da nova cadeira 'Estética. Composição Geral e Urbanismo I e ll', Anhaia

Mello deu início ao ensino da disciplina que se tornaria sua especialidade: o Urbanismo.

Criticava a formação excessivamente racional dos engenheiros, por não acreditar que o progresso técnico fosse incompatível com a beleza.

Segundo depoimento de seus alunos e discípulos, entre eles, Vilanova Artigas e Osvaldo Correa Gonçalves, Anhaia M ello foi o professor de maior influência do curso de Engenheiro-Arquiteto nas décadas de $30 \mathrm{e}$ 40. Era um homem de grande cultura e um grande teórico, não se preocupando muito com a prática de projetos. Suas aulas eram verdadeiras conferências sobre arte e vida que entusiasmavam os estudantes. Com Zenon, não foi diferente.

Seu trabalho de conclusão de curso já denunciava uma influência dos preceitos modernos (geometria regular e limpa, livre de ornamentos), mostrando o momento de transição pelo qual a arquitetura brasileira passava, e sua sintonia com estes acontecimentos (como veremos adiante).

M uito importante lembrar que a formação acadêmica de Zenon Lotufo orientou-se pelos ensinamentos tradicionais e clássicos da École de
Beaux-arts francesa, a qual influenciou praticamente todas as primeiras escolas de arquitetura do Brasil, em conformidade com o que ocorria em todos os países marcados pela cultura européia.

A primeira parceria profissional foi realizada com o também colega engenheiro-arquiteto Afonso lervolino, vencendo alguns concursos públicos: o Paço M unicipal de Taquaritinga e o M ercado Municipal de Sorocaba (apenas este último construído) ambos projetados em 36. Paralelamente, iniciou sua carreira pública na Diretoria de Obras da Secretaria de Viação e Obras da Prefeitura de São Paulo (1937-1938). Transferiu-se para a Secretaria de Obras de Santos, na qual atuou como Chefe da Divisão (1939-1945) e, finalmente, entre 46 e 47, exercendo o cargo de Prefeito da Estância de Campos do J ordão, por nomeação e para a qual elaborou o Plano Diretor.

Em Santos, desenvolveu importantes trabalhos como o Código de Obras e os projetos para a Orla M arítima e seus Postos de Salvamento (43-44), o Aquário e Orquidário Municipal (43-46), além de algumas residências e edifícios de apartamentos.

Em meados de 46, Zenon Lotufo retornava a São Paulo onde desenvolveu parceria com os arquitetos cariocas: Hélio Queiroz Duarte e Abelardo Riedy de Souza.

Abelardo Riedy de Souza, nascido em 1908, formou-se arquiteto pela Escola Nacional de Belas Artes no Rio de Janeiro em 1932, pertencente, 
portanto à geração de arquitetos que mudou os rumos da arquitetura brasileira.

Os anos de sua formação foram turbulentos, pois nessa época a ENBA passou por processo intenso de reforma introduzido por Lúcio Costa.

"Víamos através das poucas revistas que nossos colegas Carlos Leão, Luiz Nunes e Affonso Reidy traziam que existia um franco-suíço chamado Charles Edouard J eanneret, mais conhecido como Le Corbusier, que abria os olhos do mundo para uma nova maneira de viver". ${ }^{9}$

A influência da escola carioca começava a aparecer na presença de linhas sinuosas e maior leveza plástica que se somam ao racionalismo estrutural do engenheiro politécnico.

0 grupo realiza inúmeros projetos importantes, como o projeto para 0 concurso para a nova sede do Instituto de Arquitetos do Brasil,

Departamento de São Paulo, o qual vencem juntamente com mais duas equipes formadas por Rino Levi e Roberto Cerqueira Cezar, e M iguel Forte, Jacob Ruchti e Galiano Cimpaglia. Este concurso foi julgado por um júri composto por Oscar Niemeyer, Gregori Warchavchik, Hélio Uchoa, Firmino Saldanha e Fernando Britto que concluiu pelo empate entre as três equipes paulistas.

\footnotetext{
${ }^{9}$ SOUZA, A. R. de. Arquitetura no Brasil: Depoimentos. Diadorim/EDUSP, São Paulo, 1978.
}

Outras parcerias com arquitetos paulistas ainda marcaram sua obra no final da década de 1940: com Gregori Warchavichk, a sede do Clube Atlético Paulistano em São Paulo (1949); e com Plínio Croce, a sede da Faculdade de Engenharia Industrial da PUC-SP em São Bernardo do Campo (1949).

Nos anos 50, a arquitetura moderna brasileira já havia assumido uma posição de reconhecimento tanto no exterior como aqui mesmo. Oscar Niemeyer assumia o posto de maior arquiteto brasileiro tendo realizado importantes obras, a partir do projeto do M inistério da Educação e Saúde, em equipe com Lúcio Costa.

A grande admiração por Le Corbusier ficou registrada em um artigo publicado na revista Acrópole em abril de 1949, chamado "A influência dos mestres" onde Zenon afirma que 0 arquiteto francês "provocou uma verdadeira revolução em nosso meio arquitetônico".

Em 51, Zenon integrou a equipe de Oscar Niemeyer no projeto dos pavilhões de exposição do IV Centenário de São Paulo no Parque Ibirapuera.

De 49 a 57, foi professor contratado como catedrático na cadeira n. 16 "Composição de Arquitetura" do primeiro ano do curso da Faculdade de Arquitetura e Urbanismo da Universidade de São Paulo, fato que terminou de forma polêmica em virtude da conclusão negativa do 
Concurso de Cátedra que afastou Zenon das atividades acadêmicas por quase 10 anos.

Neste Concurso, defendeu a tese "O espaço psicológico na Arquitetura", texto posteriormente premiado pelo Conselho Regional de Engenharia, onde discute a importância da sensação psicológica que o espaço arquitetônico tem de oferecer.

De 58 a 65, venceu vários concursos nacionais de arquitetura com a parceria de Ubirajara M otta Ribeiro. E em seguida de 67 a 73, com seu filho Vitor Amaral Lotufo, realizou novos projetos e planos urbanísticos relevantes entre eles: Plano Diretor de Limeira, Cordeirópolis e Iracemápolis. Em 67, voltou às atividades acadêmicas e ao ensino. Inicialmente, ao curso de Engenharia Civil da Escola Politécnica apresentando um ensaio "Arte ou artifício" (breve estudo da evolução forma-estrutura ao longo da história da arquitetura) e depois a FAUUSP, como auxiliar de ensino, aposentando-se em 1980, e vindo a falecer em 85, em sua cidade natal: Botucatu.

Na página seguinte, resumimos em um quadro, alguns dos fatos mais relevantes na trajetória de Zenon: 


\begin{tabular}{|c|c|c|c|c|c|c|c|c|}
\hline Século XX & 1911-20 & 1921-30 & 1931-40 & 1941-50 & 1951-60 & $1961-70$ & $1971-80$ & $1981-90$ \\
\hline Vida/obra & $\begin{array}{l}1911 \\
\text { Nascimento } \\
\text { em } \\
\text { Botucatu/SP } \\
\text { (filho de } \\
\text { imigrantes } \\
\text { italianos) }\end{array}$ & $\begin{array}{l}\text { Termina } \\
\text { seus } \\
\text { estudos Rio } \\
\text { de Janeiro }\end{array}$ & $\begin{array}{l}1936 \\
\text { Forma-se engenheiro- } \\
\text { arquiteto Escola } \\
\text { Politécnica } \\
\text { Universidade de São } \\
\text { Paulo } \\
\text { 1937-38 } \\
\text { Obras Publicas } \\
\text { Prefeitura de São } \\
\text { Paulo }\end{array}$ & $\begin{array}{l}\text { 1939-45 } \\
\text { Chefe da } \\
\text { Divisão de } \\
\text { Obras na } \\
\text { Prefeitura de } \\
\text { Santos } \\
1946 \\
\text { Prefeito de } \\
\text { Campos do } \\
\text { Jordão }\end{array}$ & $\begin{array}{l}\text { 1949-57 } \\
\text { FAU-USP e } \\
\text { Concurso : } \\
\text { "O Espaço } \\
\text { Psicológico da } \\
\text { Arquitetura" } \\
\text { 1951-54 } \\
\text { Niemeyer e } \\
\text { Projeto do } \\
\text { Ibirapuera }\end{array}$ & $\begin{array}{l}\mathbf{1 9 6 7} \\
\text { Seu filho, Vitor } \\
\text { passa a } \\
\text { integrar o } \\
\text { escritório } \\
\mathbf{1 9 6 9} \\
\text { Diretor da } \\
\text { Serpla } \\
\text { (Serviços de } \\
\text { Planejamento) }\end{array}$ & $\begin{array}{l}1973 \\
\text { Projeto da } \\
\text { Rodoviária de } \\
\text { Limeira }\end{array}$ & $\begin{array}{l}1981 \\
\text { Aposenta-se } \\
\text { como auxiliar } \\
\text { de ensino } \\
\text { FAUUSP } \\
\mathbf{1 9 8 5} \\
\text { Falece } \\
\text { em Botucatu }\end{array}$ \\
\hline Brasil & $\begin{array}{l}\text { República } \\
\text { Café com } \\
\text { Leite }\end{array}$ & $\begin{array}{l}1922 \\
\text { Semana de } \\
\text { Arte } \\
\text { Moderna } \\
1930 \\
\text { Estado } \\
\text { Novo } \\
\text { Getulio } \\
\text { Vargas }\end{array}$ & $\begin{array}{l}1937 \\
\text { Ministério da } \\
\text { Educação e Saúde } \\
\text { (Lúcio Costa, Oscar } \\
\text { Niemeyer e equipe) }\end{array}$ & $\begin{array}{l}1942 \\
\text { Conjunto de } \\
\text { Pampulha } \\
\text { (Oscar } \\
\text { Niemeyer) }\end{array}$ & $\begin{array}{l}\text { 1956-61 } \\
\text { Governo } \\
\text { Juscelino } \\
\text { Kubistchek }\end{array}$ & $\begin{array}{l}1961 \\
\text { Inauguração } \\
\text { de Brasília } \\
1964 \\
\text { Golpe militar }\end{array}$ & $\begin{array}{l}1970 \\
\text { Pavilhão do } \\
\text { Brasil, Osaka } \\
\text { (Paulo } \\
\text { Mendes da } \\
\text { Rocha) }\end{array}$ & $\begin{array}{l}1984 \\
\text { Movimento } \\
\text { Diretas-Já } \\
1988 \\
\text { Constituição }\end{array}$ \\
\hline Mundo & $\begin{array}{l}\text { 1914-18 } \\
\text { 1a. Guerra } \\
\text { Mundial }\end{array}$ & $\begin{array}{l}1929 \\
\text { Quebra da } \\
\text { Bolsa de NY }\end{array}$ & $\begin{array}{l}1933 \\
\text { Carta de Atenas } \\
\text { (CIAM IV) }\end{array}$ & $\begin{array}{l}\text { 1939-45 } \\
\text { 2a. Guerra } \\
\text { M undial }\end{array}$ & $\begin{array}{l}1956 \\
\text { "Team X" }\end{array}$ & & $\begin{array}{l}1973 \\
\text { Crise do } \\
\text { petróleo }\end{array}$ & \\
\hline
\end{tabular}


"Embora o Brasil nunca tenha estado no centro da cultura clássica, e esteja bastante distante dos grandes monumentos

dessa tradição, o país foi alvo da difusão sistemática do

conhecimento

tradicional erudito no século XIX, com a vinda

da M issão Artística Francesa e com a criação da Academia Imperial de Belas Artes, que impulsionaram a cultura plástica local em direção ao Neoclassicismo. A primeira geração

de arquitetos modernos brasileiros foi formada de acordo com esse sistema acadêmico, e moldou sua linguagem moderna sob a forte influência de Le Corbusier, dois fatos que

justificam a transposição da discussão sobre modernidade e tradição clássica para o Brasil". ${ }^{10}$

\section{1 - Introdução}

0 intuito deste primeiro capítulo é rever os aspectos da formação acadêmica do engenheiro-arquiteto Zenon Lotufo, a partir de certa tradição clássica apoiada nos conhecimentos tratadísticos da École des

${ }^{10}$ PONTES, A.P.G. Diálogos silenciosos: arquitetura moderna brasileira e tradição clássica. Dissertação de mestrado, PUC-RJ, 2004, pg. 13. 
Beaux-Arts, presente no ensino do curso de Engenheiro-Arquiteto da Escola Politécnica de São Paulo, e o rebatimento em sua produção profissional, procurando compreender e relacionar os vínculos entre a teoria e a prática na obra do arquiteto.

Antes disso, parece-nos importante investigar um pouco do contexto de idéias e acontecimentos presentes nas cidades de Rio de Janeiro e São Paulo nas décadas de 20 e 30, onde Zenon permaneceu períodos importantes e decisivos, numa época de agitação política dentro do quadro nacional.

Atentamos também para a origem e aplicação do chamado método Beaux-arts (Belas-Artes) procurando relacioná-lo com a estrutura do curso e a influência dos ensinamentos de Luis Ignácio de Anhaia M ello (1891-1974), professor catedrático do curso de Composição Geral, Estética e Urbanismo e principal referência para os alunos na época. E finalmente, apresentar seus primeiros trabalhos realizados, inicialmente em parceria com o colega de Politécnica, Affonso lervolino, seguidos por sua atuação na administração pública de Santos (39-45), como diretor comissionado da Secretaria de Obras Públicas e posteriormente sua nomeação como prefeito da Estância Sanitária de Campos do Jordão (46), onde coordenou o Plano Diretor.

\section{2. Contextos}

\section{Rio de Janeiro e São Paulo entre as décadas de 20 e 30}

Os principais acontecimentos políticos que marcaram o final da década de 20 e início da década de 30 nas cidades do Rio de Janeiro (então capital federal) e São Paulo determinaram importantes transformações culturais e o processo de introdução do movimento moderno, influenciando também o ensino e a prática da arquitetura da época.

A efervescência dos anos 20, principalmente na Europa, soprou seus ares pelo mundo afora tendo encontrado também repercussão em terras brasileiras, mais especificamente, através dos jovens que iam para lá estudar e traziam uma nova visão em relação a costumes, cultura e arte. Invenções tecnológicas como o cinema falado, o gramofone e a difusão do automóvel começaram a despontar e alterar comportamentos e modos nos centros urbanos, principalmente em São Paulo e Rio de Janeiro.

Em São Paulo, aconteceria a Semana de Arte Moderna de 22 que pontuou o cenário cultural paulista com a participação de nomes como Mário de Andrade, Oswald de Andrade e companhia. Este movimento significou uma espécie de renascimento artístico, pois buscava seus temas e expressões nas fontes do nosso passado colonial, ao olhar o homem da terra, do índio, do mulato e do negro, porém com uma visão libertadora capaz de imprimir novos valores de identidade nacional. 
No livro Arquitetura Brasileira, Carlos Lemos afirmou que os arquitetos que participaram da Semana de 22, Álvaro M oya e Georg Przirembel, não tinham a menor noção do racionalismo estrutural e muito menos do modernismo que vinha sendo praticado na Europa. 0 estilo desenvolvido por eles tinha caráter eclético e neocolonial, ou seja, muito mais comprometido com o passado do que alinhado com a produção de vanguarda.

“O grosso dos nossos arquitetos seguia as regras clássicas de composição, a mercê dos ensinamentos de seus mestres antiquados, nos cursos de formação arquitetônica ministrados nas escolas de engenharia, a Politécnica e a Mackenzie". ${ }^{11}$

Em novembro de 1925, o arquiteto russo Gregori Warchavchik publicava o famoso artigo-manifesto Acerca da arquitetura moderna no Correio da Manhã do Rio de Janeiro, onde defendia a necessidade de se superar os preconceitos estilísticos e afirmava que a economia e a funcionalidade deveriam prevalecer no projeto arquitetônico.

Quinze dias antes, o paulista Rino Levi (ainda estudante de arquitetura em Roma) debatia no jornal 0 Estado de São Paulo sobre a falta de planejamento das cidades brasileiras a mercê das vontades e padrões do capital imobiliário.

\footnotetext{
${ }^{11}$ Lemos, C. Arquitetura Brasileira. M elhoramentos, São Paulo, 1979, pg. 133.
}

"Sente-se ainda a influência do classicismo que, aliás, hoje, se estuda melhor procurando-se sentir e interpretar seu espírito, evitando-se a imitação, já bastante desfrutada de seus elementos". ${ }^{12}$

Ou seja, apesar dos primeiros sinais e manifestações a favor de uma nova linguagem arquitetônica capaz de expressar as mudanças que vinham ocorrendo, havia ainda muita resistência por parte da sociedade em geral em aceitar os novos padrões estéticos.

0 início da década de 30 foi um momento bastante intenso na história política e cultural do país, e conseqüentemente para a arquitetura. Segundo Abelardo de Souza: "Podemos dividir a história da nossa arquitetura em duas partes ou épocas distintas: antes de 1930 e depois de 1930". ${ }^{13}$

A revolução de 30 tendo a frente o gaúcho Getúlio Vargas como figura central do movimento armado simbolizou a derrubada da República Velha ou, se preferirmos, a alternância da oligarquia cafeeira paulista e mineira no controle político nacional.

Fatores como a quebra da Bolsa de Nova York em 29, aliada à emergência de uma classe média, uma incipiente burguesia e o crescimento do

\footnotetext{
${ }^{12}$ Levi, R. A arquitetura e a estética das cidades (1925). Xavier, A. (org.) Depoimento de uma geração. Cosac \& Naify, São Paulo, 2003, pg. 38.

${ }^{13}$ Souza, A. A ENBA, antes e depois de 1930. em Depoimento de uma geração, org. Alberto Xavier. Cosac Naify, São Paulo, 2003, pg. 63.
} 
movimento operário também contribuíram para a mudança de paradigma econômico com o início da consolidação da produção industrial.

Paralelamente, a nomeação do jovem Lúcio Costa em 1930 para assumir a direção da Escola Nacional de Belas Artes, então principal escola de artes da capital federal, pode ser considerada também um marco transitório na história da arquitetura brasileira. Suas ações quanto à reforma do currículo aliada à nomeação de novos professores como Gregori Warchavchik, Affonso Eduardo Reidy, Alexander Buddeus, Emilio Baumgart entre outros significaram uma nova orientação no modo de ensinar arquitetura.

"Passamos de uma longa fase de cópias de modelos e fórmulas arquitetônicas para a criação. 0 Vignola foi solenemente queimado e suas cinzas espal hadas pelas praias do Rio. Passamos a estudar temas mais práticos como a "casa mínima", postos de gasolina, grupos escolares, equipamentos de cozinha e banheiro. Esta era uma coisa que desconhecíamos até então: a função das coisas que éramos chamados a projetar". ${ }^{14}$

Os mestres de formação européia como Warchavchik, Baumgart e Buddeus mostravam as soluções da arquitetura moderna na Europa com o uso de fachadas lisas e ausência de ornamentos, telhados planos e os jardins suspensos, mas ainda via-se nas plantas e estruturas resquícios da

\footnotetext{
${ }^{14}$ Souza, A., opt. Cit., pg. 67.
}

arquitetura clássica. Neste ambiente, floresciam os primeiros arquitetos modernos do Brasil: Oscar Niemeyer, Carlos Leão, Jorge Moreira, Luiz Nunes entre outros que impulsionaram a nova arquitetura que resplandecia.

Não por acaso, em dezembro de 1930, Lúcio Costa publicou no jornal “O Globo" um texto bastante elucidativo onde alertava sobre as condições de ensino, apontando sua preocupação com o disparate exagerado entre a arquitetura e a estrutura, modelo este que persistia no curso de arquitetura na Escola de Belas Artes.

“Em todas as grandes épocas, as formas estéticas e estruturais identificam-se. Nos verdadeiros estilos, arquitetura e construção coincidem. E quanto mais perfeita a coincidência, mais puro o estilo. Partenon, Reims, Santa Sofia, tudo construção, tudo honesto, as colunas suportam, os arcos trabalham. Nada mente". ${ }^{15}$

0 anacronismo entre as realizações européias e as de solo brasileiro perpetuava-se por anos a fio e precisava ser transformada a partir de uma reforma séria na estrutura do curso, denunciava Costa. Ele (que havia estudado em países como Inglaterra, França e Suíça) criticava não só a formação acadêmica oferecida, mas seu reflexo nas práticas exageradas

\footnotetext{
${ }^{15}$ COSTA, L. A situação do ensino das Belas-Artes. Em XAVIER, A. org. Depoimento de uma geração. Edição original,1987. Cosac Naify, São Paulo, 2003, pg. 57.
} 
da construção rotulando-as de mera simulação e cenografia arquitetônica.

Segundo Costa, os tratados clássicos e os estilos históricos deveriam ser estudados apenas como referência crítica, enquanto que as lições construtivas advindas de nosso passado colonial guiariam o futuro da arquitetura tendo em vista seus principais aspectos de "simplicidade, perfeita adaptação ao meio e à função, e conseqüente beleza".

Reclamando também da falta de conhecimento e sintonia dos artistas e arquitetos com os acontecimentos e questões que se faziam presente no resto do mundo, Lúcio professou a abertura do Salão de Belas Artes de 1931, evento de importante significado histórico que abriria caminho às novas manifestações artísticas de Cândido Portinari, Di Cavalcanti, Ismael Nery, Alberto Guignard e Cícero Dias, entre outros.

Formado pela Escola de Belas Artes do Rio de Janeiro em 1924, 0 arquiteto teve seu ensino pautado pelo gosto neoclássico e eclético e suas primeiras experiências profissionais situaram-se no estilo neocolonial. Suas reflexões sobre arquitetura brasileira marcaram a excelência do pensamento crítico nacional onde procurava sempre aliar tradição e modernidade.

Portanto, este quadro de acontecimentos culturais marcava 0 ambiente carioca do início da década de 30, onde o arquiteto Zenon Lotufo esteve presente por ocasião do ingresso no curso de Engenheiro-Civil da Politécnica do Rio de Janeiro em 31.

\section{Revolução constitucionalista de 32}

Em 1930, uma revolução derrubou do governo os grandes latifundiários de M inas Gerais e São Paulo. 0 gaúcho Getúlio Vargas assumia a presidência do Brasil em caráter provisório, mas com amplos poderes. Todas as instituições legislativas foram abolidas, desde o Congresso Nacional até as Câmaras M unicipais, sendo os governadores dos Estados depostos.

A política centralizadora iniciada por Vargas desagradava às oligarquias cafeeiras, especialmente as de São Paulo, e as elites políticas do Estado economicamente mais importante sentiam-se prejudicadas, reivindicando a realização de eleições e o fim do governo provisório.

O governo Vargas reconheceu oficialmente os sindicatos dos operários e legalizou o Partido Comunista, apoiando um aumento no salário dos trabalhadores, o que irritou ainda mais as elites paulistas.

Assim, em 1932, uma greve mobilizou 200 mil trabalhadores no Estado, onde empresários e latifundiários de São Paulo se uniram contra o governo de Vargas.

No dia 23 de maio, um comício reivindicou uma nova constituição para o Brasil, porém o evento terminou de modo trágico com a morte de quatro 
estudantes: M artins, M iragaia, Dráuzio e Camargo. As iniciais M M DC se transformariam no grande símbolo da revolução.

Em julho, explodiu a revolta. As tropas rebeldes se espalharam pela cidade de São Paulo e ocuparam as ruas.

Enquanto a imprensa paulista defendia a causa dos revoltosos, a população aderiu à rebelião com um grande número de pessoas se alistando para a luta. Tropas paulistas foram enviadas para as frentes de batalha, mas as tropas federais eram mais numerosas e bem equipadas. Cerca de 40 mil homens de São Paulo enfrentaram um contingente de 100 mil soldados, enquanto os revoltosos esperavam a adesão de outros Estados, o que não aconteceu.

Em outubro de 32, após três meses de luta, os paulistas se renderam. Prisões, cassações e deportações se seguiram às estatísticas oficiais de 830 mortos. Estima-se que centenas a mais de pessoas morreram sem constar dos registros oficiais.

A Revolução Constitucionalista de 1932 foi o maior confronto militar do século XX no Brasil e apesar da derrota paulista em sua luta por uma constituição, dois anos depois da revolução, em 1934, uma assembléia eleita pelo povo promulgaria a nova Carta Magna. Os reflexos desses acontecimentos influenciaram a vinda de Zenon Lotufo para a cidade de São Paulo, uma vez que dois irmãos seus lutaram como voluntários na Revolução, aliado também ao fato de ter conhecido sua futura esposa
Coraly (nesta época com 12 anos) ${ }^{16}$ o que determinou, entre outros fatores, seu pedido de transferência para a Escola Politécnica de São Paulo em 33.

\section{Zenon, a Politécnica e a vinda para São Paulo}

Zenon havia sido admitido na Escola Politécnica do Rio de Janeiro em 1931, mas transferiu-se mais tarde para o curso de Engenheiro-Arquiteto da Escola Politécnica de São Paulo em 1933, como contamos acima.

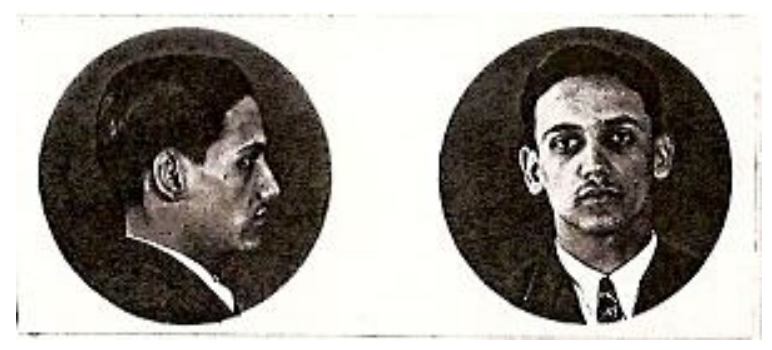

Fig. 2: Zenon Lotufo aos 21 anos (Fonte: Pasta de aluno - Arquivo Técnico EPUSP)

Em março, Zenon Lotufo apresentou guia de transferência do curso de Engenheiro-Civil da Escola Polytechnica (segundo grafia da época) da Universidade do Rio de Janeiro. Nele constavam as médias de seus exames preparatórios, realizados no Lyceu de Botucatu entre os anos de 27 e 29, que mencionamos a seguir: Português $(8,0)$, Francês $(4,5)$, Inglês

\footnotetext{
${ }^{16}$ Entrevista com Coraly Lotufo (1919- ), concedida em Botucatu, em 04 de outubro de 2007.
} 
(9,0), Latim (5,0), Aritmética (8,5), Álgebra (8,0), Geometria e Trigonometria (7,5), Geografia $(7,0)$, História do Brasil $(8,5)$, História Universal $(6,5)$, Física e química $(8,0)$ e História Natural $(8,0) .{ }^{17}$

Em 7 de abril de 1931, prestou o vestibular sendo aprovado com nota 5,0 (cinco) ingressando no primeiro ano de engenharia civil na Polytechnica do Rio de Janeiro onde cursou: Cálculo $(7,0)$, Geometria Analítica $(9,0)$, Geometria Descritiva e Projetiva (6,0), Geologia econômica e Metalurgia $(5,37)$ e Desenhos de Ornatos à mão livre $(7,83)$. No segundo ano (32), cursou apenas duas disciplinas: Mecânica, Cálculo Vetorial e Resistência dos Materiais $(6,0)$ e Química Inorgânica $(5,37)$.

Já em São Paulo, em 1933, Zenon freqüentou disciplinas referentes ao primeiro e segundo ano do curso de Engenheiro-Civil (Física I e II $(13,0)$, Desenho Topográfico $(12,5)$ e Desenho de Perspectiva $(15,0))$, mas já havia solicitado em carta a secretaria da Escola Politécnica (datada de 28 de março de 1933) sua transferência para o curso de EngenheiroArchitecto.

A partir de 34, Lotufo freqüentou as disciplinas do 3‥ Ano do curso onde teve: Composição Geral (pontuação final - 18), Desenho de Perspectiva (16), Tecnologia Civil $(13,8)$ e Oficinas (18). Durante o 4․ Ano (35), realizou os seguintes cursos obtendo os respectivos graus: Composição Geral $(9,0)$, Resistência e Estabilidade $(6,6)$, História da Arquitetura $(5,5)$,

\footnotetext{
${ }^{17}$ Pasta de aluno da EPUSP.
}

Construção Civil (6,8), Hidraulica (6,7), Oficinas (6,0) e Laboratórios (7,0). Seu último ano como aluno da Escola Politécnica no ano de 1936, Zenon finalizou as cadeiras de: Composição Geral e Urbanismo $(8,9)$, Economia política $(8,0)$, Hidráulica Urbana e Saneamento $(8,0)$ e Contabilidade $(6,5)$, obtendo o diploma de Engenheiro-Arquiteto em 18 de dezembro de 1936.

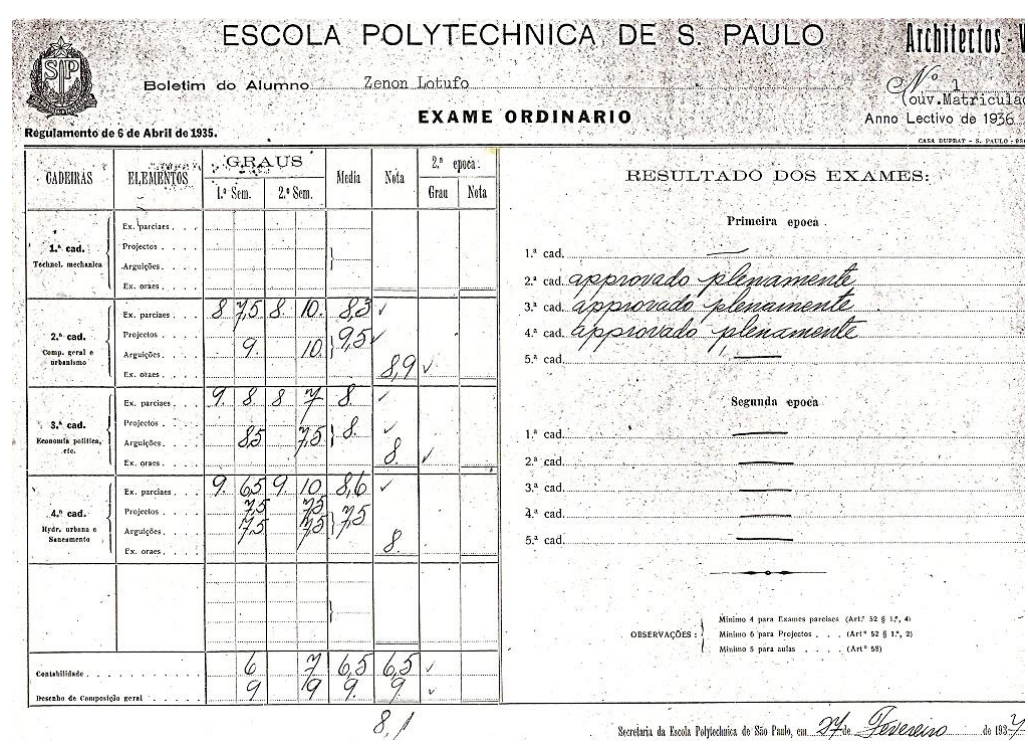

Fig. 3: Boletim de Zenon Lotufo de 1936 (5‥ Ano do curso de Engenheiro-Arquiteto) (Fonte: Pasta de aluno Arquivo Técnico EPUSP).

\section{O ensino na Politécnica de 1932 a 1954}

"O ensino de Arquitetura na década de 30 pressupunha a existência de modelos e de um elenco de elementos a serem compostos. Para isso, o desenho e a história deveriam fornecer esta bagagem. 
Estudavam-se os estilos como sistemas fixos e padronizados onde as simplificações gráficas levavam a uma leitura deturpada e estereotipada da História. Ou seja, a renovação do ensino foi conseqüência de uma nova prática profissional". ${ }^{18} \mathrm{O}$ curso de Engenheiro-Arquiteto no período de 1932 a 1954 (data em que se encerra o oferecimento desta formação específica na Escola Politécnica de São Paulo) continuou sendo uma opção de poucos alunos. As turmas eram exíguas, fato que colaborou para a extinção do mesmo na década de 50, aliado também à fundação da FAUUSP. ${ }^{19} \mathrm{No}$ entanto, a evolução do número de engenheiros-arquitetos formados, década a década, a partir de sua inauguração é notória. Porém, seu crescimento se deu mais rapidamente na década de 30, como vemos na tabela a seguir ${ }^{20}$ :

\section{Período (1899-1954)}

\section{n. engenheiros arquitetos formados}

1899 - 1910 -

\section{1- 1920 -}

\section{1-1930 -}

13

\footnotetext{
${ }^{18}$ Santos, L. C. Arquitetura Paulista em torno de 1930-40. M estrado. FAUUSP, São Paulo, 1985.

${ }^{19}$ Ficher, Silvia. Os arquitetos da Poli: Ensino e Profissão em São Paulo. EDUSP, São Paulo, 2005, p. 256.

${ }^{20}$ Santos, M. C. L. Escola Politécnica (1894-1984). Edusp, São Paulo, 1985, p. 256.
}

\section{$1931-1940$}

1941-1954-

Total -

O curso de Engenheiro-Arquiteto da Escola Politécnica foi a primeira formação do gênero em São Paulo e representava um novo modelo pedagógico, em comparação com a Escola de Belas Artes, em virtude de ser um curso voltado para engenheiros e construtores, apresentando assim um caráter mais racional da obra.

“É preciso frisar que apesar do cunho racionalista do ensino de arquitetura da Politécnica, nas questões de estilo e estética ainda predominava a mentalidade do classicismo" ${ }^{21}$

Basicamente, o curso se diferenciava da Engenharia Civil pelos últimos anos $\left(3^{\circ}, 4^{\circ}\right.$ e $\left.5^{\circ}\right)$ onde se ensinava desenho de representação arquitetônica, composição geral, perspectiva e técnicas de representação, história da arquitetura e urbanismo.

"O curso de engenheiros-arquitetos aliou ao rigor intrínseco das ciências exatas e das outras cadeiras integrantes da formação de engenheiros, disciplinas humanísticas, arte e desenho do projeto". ${ }^{22}$

\footnotetext{
${ }^{21}$ Santos, M. C. L. Opt. Cit., p. 256

${ }^{22}$ Santos, M. C. L. Opt. Cit., p. 239.
} 
$01^{\circ}$. Ano do Curso geral tinha como disciplinas: Cálculo Vetorial, Complementos de Geometria Analítica, Física I, Topografia, Perspectiva e Desenho Arquitetônico. Esta última era dada por Prestes M aia até 1937 e baseava-se em esboços do natural e desenhos de aquarela, feitos a partir de modelos.

O $2^{\circ}$. Ano compunha-se de M ecânica Racional, Física II, Química Geral, Aplicações Técnicas de Geometria Descritiva, Cálculo Diferencial e Integral e Desenho de Perspectiva, tendo Prestes Maia também à frente que naquela oportunidade ensinava: desenhos de fachadas, em aquarelas monocrômicas e policrômicas, exercícios e croquis de construção de perspectivas.

$03^{\circ}$. Ano estruturava-se por: Resistência e Estabilidade I, Tecnologia Civil, M ateriais de Construção, Fundações e Composição Geral I, sendo esta última ministrada por Anhaia M ello, que cuidava da composição arquitetônica e seus componentes elementares, de apoio, pórticos, estudo das ordens e detalhes da arquitetura clássica.

Além dessas, ainda havia uma cadeira de Hidráulica Urbana e Saneamento, e outra de Desenho de Composição Geral onde os alunos realizavam desenhos de ornamentação em diversos estilos, as cinco ordens de Vignola e suas aplicações em pórticos, arcadas e intercolúnios. $04^{\circ}$ ano do curso tinha Resistência e Estabilidade II, Composição Geral II, Noções de Arquitetura e Construções Civis e História da Arquitetura, Tecnologia M ecânica e também Desenho de Composição Geral.

Para a segunda parte de Composição, Anhaia M ello orientou o estudo da Estética e dos tipos de edifícios agrupando ainda temas do movimento moderno como: Le Corbusier, concreto armado, funcionalismo, etc. Sob responsabilidade do assistente era dado um exercício-tema de composição como, por exemplo, em 1935: projeto de uma residência nobre em estilo renascentista, uma igreja gótica e um edifício de apartamentos. ${ }^{23}$

Finalmente, $05^{\circ}$. Ano encerrava o curso de Engenheiro-Arquiteto com Composição Geral III e Urbanismo, História da Arquitetura, Hidráulica Urbana e Saneamento II, Economia Política e Contabilidade. Desenho de Composição Geral incluía a representação de plantas, cortes e fachadas de grandes edifícios como hospitais, teatros, cinemas, aquarelas e perspectivas.

A cadeira de Composição Geral foi introduzida ao currículo do curso no Decreto Estadual n. 1.539 (1907) entrando em vigor apenas em 1911. Esta nova organização priorizou aulas para elaboração de projetos e estudos de composição de edifícios e da estética das artes e do desenho.

\footnotetext{
${ }^{23}$ Ficher, opt. cit., pg. 262.
} 
Enquanto nas aulas de história de arquitetura, os alunos conheciam os diversos estilos, nas aulas de projeto, eles praticavam este conhecimento.

“Na cadeira de composição, tratava-se da aplicação dos vários estilos, à elevação das fachadas ou do interior, pois o seu objeto era 0 estudo das plantas dos diferentes edifícios públicos e monumentos, com a lógica distribuição de suas diversas partes. 0 valor prático da obra dependia ainda de uma boa planta lógica e organicamente projetada. Para a completa instrução ao aluno, os projetos de edifícios neste curso, precisavam ser estabelecidos segundo as regras de composição, fazendose na sua elevação, a aplicação dos diversos estilos". ${ }^{24}$

Os três principais nomes na evolução do curso de engenheiro-arquiteto da EPUSP foram: Ramos de Azevedo (1851-1928); Alexandre Albuquerque (1880-1940) e Luiz Ignácio Romeiro de Anhaia M ello (1891-1974).

Ramos de Azevedo regeu a cadeira de Arquitetura Civil e Higiene das Habitações de 1894 a 1928, sendo vice-diretor (1900-1917) e diretor (1917-1928).

Alexandre Albuquerque criou o Grêmio Politécnico em 1903, enquanto aluno, e depois, tornou-se catedrático da cadeira de História da Arquitetura. Mas talvez sua maior contribuição tenha sido a luta pela

\footnotetext{
${ }^{24}$ Santos, M. C. L. Opt. Cit., p. 243.
}

regulamentação da profissão do arquiteto promulgada no Decreto Federal n. 23.569, em 11 de dezembro de 1933.

Por sua vez, Anhaia M ello poderia ser considerado a alma do curso de engenheiro arquiteto. Era totalmente devoto ao ensino e à cadeira de Composição Geral e Urbanismo, trazendo sempre as aulas, discussões atuais onde observava o conteúdo humano e os aspectos psicológicos dos fatos. E talvez, sua maior contribuição tenha sido o projeto de criação da Faculdade de Arquitetura e Urbanismo da Universidade de São Paulo em 1948.

Nas palavras de seu filho José Luiz Anhaia M ello, em depoimento em outubro de 1983, prestado a M aria Cecília Loschiavo dos Santos:

"Era um homem que não pactuava, por assim dizer as formas simples da engenharia, quer dizer, ele não suportava apenas tijolo e cimento, ele queria dar cor a eles". ${ }^{25}$

\subsection{A influência de Anhaia Mello}

Zenon Lotufo foi o único aluno matriculado para o ano letivo de 1933 para o curso de Engenheiro-Arquiteto, de modo que o professor catedrático Anhaia M ello (responsável pela principal cadeira do curso Composição Geral, Estética e Urbanismo) tornou-se seu grande mestre inspirador e amigo próximo.

\footnotetext{
${ }^{25}$ Santos, M. C. L. Op. Cit. p. 255.
} 
A relação entre eles foi muito próxima nos anos de 33 a 36. Como exemplo dessa relação, sabe-se que quando Anhaia previa que ia faltar a aula, avisava a Zenon para não perder a viagem e vice-versa. ${ }^{26}$ Luis Ignácio Romeiro de Anhaia M ello (1891-1974) foi o professor de maior influência do curso de Engenheiro-Arquiteto nas décadas de 30 e 40. Era um homem de grande cultura e um grande teórico, não se preocupando muito com a prática de projeto. Suas aulas eram verdadeiras conferências sobre vida e arte que entusiasmavam os estudantes. Criticava a formação excessivamente racional do engenheiro e não acreditava que o progresso técnico fosse incompatível com a beleza.

No Anuário de 1946 da Escola Politécnica, Anhaia Mello publicou um interessante artigo denominado "A Evolução do Curso de Engenheiros Arquitetos na Escola Politécnica de São Paulo" onde fez um balanço do curso, sua estrutura, as cadeiras oferecidas e os professores entre outros aspectos.

No texto, remontou a origem da escola inaugurada em fevereiro de 1894, relembrando o fato de que a Arquitetura do final do século XIX não dialogava mais com construção, ou seja, valorizavam-se predominantemente aspectos estéticos de massa e volume, enquanto que função e estrutura ficavam em segundo plano. Só este dado em si já

\footnotetext{
${ }^{26}$ Depoimento de Coraly Lotufo em 25 de novembro de 2006
}

parecia justificar o oferecimento de uma especialidade como a Arquitetura, no quadro de formação da escola, segundo Anhaia. 0 conteúdo do curso de Engenheiro-Arquiteto compunha-se originalmente por cadeiras especiais, de acordo com Decreto 270-A de 20 de novembro de 1894, sendo o 1‥ Ano - 3a . Cadeira - Elementos de Arquitetura. Estudo de detalhes, o 3‥ Ano - 2a . Cadeira - Estética das Artes do Desenho e 3a. Cadeira - História da arquitetura. Estilos diversos. 0 decreto 1.992, de 27 de janeiro de 1911, desenvolveu melhor a disciplina de Composição Arquitetônica e as cadeiras passaram a ser: 2ㅇ. Ano - 3a. Cadeira - Elementos dos edifícios. Composição geral. 1ª. Parte: Habitações, 3ํ. Ano - 2a. Cadeira - Composição Geral. 2ª . Parte: Edifícios públicos. Estética das artes do desenho e 3ạ. Cadeira - História de arquitetura. Estudo de estilos diversos.

0 decreto 2.931, de 12 de junho de 1918, alteraria novamente a distribuição das cadeiras: 2ํ. Ano - 2ª . Cadeira - Composição Geral. $1^{a}$. Parte: Habitações; 3a . Cadeira - História da arquitetura. 1ạ. Parte: Estética; 3‥ Ano - 1a. Cadeira - Composição Geral. 2ª parte: Edifícios públicos e 2a . Cadeira - História da arquitetura. 2ª. Parte: Estética. Em 31 de dezembro de 1925, criou-se a lei n. 2.128 que incluía a cadeira de Urbanismo entre as cadeiras especiais do 3‥ Ano do curso. $E$ finalmente, o decreto 5.064, de 13 de junho de 1931, estabeleceu que 0 estudo da Composição Arquitetônica se estendesse pelos três anos do 
curso de Engenheiro-Arquiteto. Anhaia afirmou ainda, no mesmo artigo:

"A primeira idéia fundamental é que a arquitetura de hoje deve tornar belos e eficientes todos os novos edifícios que os novos problemas do século estão exigindo. A segunda é que devemos desenvolver uma arquitetura livre de preconceitos de estilos históricos que faça uso criativo de todos os novos materiais que a indústria e a ciência estão fornecendo. E a terceira idéia fundamental do pensamento arquitetônico contemporâneo é que para realizar as duas primeiras idéias - novas formas adaptadas a novos problemas e novos materiais - é necessária uma nova criação estética, lógica, serena e simples. Ser belo é função tão real e necessária de qualquer edifício, como ser conveniente e resistente". ${ }^{27}$

A seguir, comentamos alguns outros textos de Anhaia M ello, de modo a contribuir para a construção de seu ideário e a influência destes valores na formação de Zenon Lotufo.

\section{Centenário de Ramos de Azevedo}

Em discurso proferido em 1951 por razão do 1o. Centenário de Nascimento de Francisco Paula Ramos de Azevedo (1851-1928), Anhaia

\footnotetext{
${ }^{27}$ Trecho extraído do texto "A Evolução do Curso de Engenheiros Arquitetos na Escola Politécnica de São Paulo" de Luiz de Anhaia M ello, parte integrante do Anuário da Escola Politécnica de 1946, p. 155.
}

Mello resgatou o prestigioso percurso traçado pelo célebre professor da Politécnica e reconhecido arquiteto paulista. ${ }^{28}$

Chamava à atenção a eloqüência e poética humanista do orador onde destacava que em primeiro lugar deveria vir sempre o progresso espiritual-moral e depois a serviço deste, a civilização ou progresso técnico-material.

Assim, o autor recorda-nos da imortalidade do artista e da importância da obra de arte:

"O artista não morre. A arte dá o que a realidade nega ao homem: a eternidade; e 0 artista se subtrai à fatalidade do destino e sobrevive na Beleza das obras que plasmou. Mas há algo de imperecível, algo de mais perene que o bronze e o granito - o conjunto da obra social, a vida de um grande cidadão. E a vida pode e deve ser uma grande Forma, forma estética, de profundo sentido espiritual, verdadeira obra de arte, portanto. Por que arte é justamente isso, o processo de dar conteúdo espiritual àquilo que se faz. Linguagem da sensibilidade, revelação das almas, a Arte é a pedra de toque das nações. 0 espírito de uma época sobrevive nas obras de Beleza que criou - e estas são o melhor e às vezes o único intérprete de uma civilização. A elas pediremos o comentário fiel da

\footnotetext{
${ }^{28}$ Discurso escrito à mão pelo próprio Luiz de Anhaia M ello por ocasião da comemoração do Centenário de nascimento de Ramos de Azevedo em dezembro de 1951, documento original existente no Arquivo Técnico da Escola Politécnica, da Universidade de São Paulo.
} 
História; a tradução sem deformação e sem lacunas, da alma dos povos". 29

\section{Toda arte é reação}

Segundo Anhaia, toda arte deveria ser reação e expressão. Reação do artista diante do mundo e expressão da personalidade do artista. Artista e coletividade seriam conceitos polares, não se pode conceber um sem 0 outro. Dando seqüência a seu discurso, Anhaia exaltou a disciplina arquitetônica apoiando-se na tríade vitruviana:

"Arquitetura, arte social por excelência, a mais rica de todas: berço, vida, túmulo e recordação do Homem. Símbolo sugestivo da humanidade civilizada, a arquitetura une a poesia da vida a toda a riqueza do mundo sensível. É obra comum de um povo, de um céu, de uma terra, testemunho de suas crenças, de seus sonhos, de sua vida - forma concreta de seu gênio. É pela construção e pela técnica que o arquiteto organiza espaços e se exprime. A realização arquitetônica é sempre uma pesquisa de equilíbrio entre as três condições da forma construída:

Utilidade - resposta da Forma à Função; Solidez- resposta da Estrutura à Matéria, e Beleza - resposta às leis da Ordem visível da matéria no Espaço, satisfeitas pelo Deleite espiritual." 30

\footnotetext{
${ }^{29}$ Idem, pg. 9.

${ }^{30}$ Ibidem, pg. 13
}

A seguir, Anhaia fez uma critica ao momento por que passava a cultura ocidental do século XX. Crise que para ele não possibilitava um olhar atento e sereno devido à dinâmica das transformações de todas as ordens do mundo capitalista e a competição que estimulava a agressão e não, a pacificação (interessante observar a atualidade do texto).

"Vivemos sob ação e pressão de complexos. Complexo de atividade, de expediente, de força, de ansiedade e preocupação com 0 futuro. Sacrificamos as belezas do presente pelas ânsias do porvir. Vivemos numa época em que muitos desconhecem que o homem vale pelo seu caráter e não pelo seu sucesso. M uitos atribuem à ciência, um papel moral que ela não possui. 0 fim da ciência é apenas compreender e prever. Seu fundamento é essencialmente essa estranha necessidade de unificar que caracteriza o espírito humano; sua base, a fé na continuidade dos fenômenos e na harmonia do seu encadeamento. No entanto, nós, homens, vivemos na esfera das ilusões, dos sentimentos, das paixões, dos desejos, da Beleza e da Moral, esferas que a ciência não atinge" ${ }^{31}$

Após o pessimismo oriundo de duas Guerras Mundiais, aquele era um momento de vestígios pessimistas e negativistas, no entanto Anhaia reafirmava a importância de se olhar e valorizar o passado e seu otimismo em relação ao futuro.

\footnotetext{
${ }^{31}$ Ibidem, pg. 19-20.
} 
E concluindo, Anhaia reafirmava que o problema do presente seria uma questão de caráter.

“Uma falta de visão sadia, consciente do passado, do feito de nossos antecessores, homens corajosos que trilharam com grandeza e vitalidade, a fim de encontrar a harmonia e a beleza em seus ideais de futuro".

Anhaia M ello envolveu-se timidamente com arquitetura tendo realizado apenas algumas casas, o Colégio e Igreja São Luiz na Avenida Paulista (fig.4), a Igreja do Espírito Santo à Rua Frei Caneca e a M atriz da M ooca. Sua preferência de estilo sempre foi o classicismo, a busca da unidade, simetria, equilíbrio e da proporção na composição.

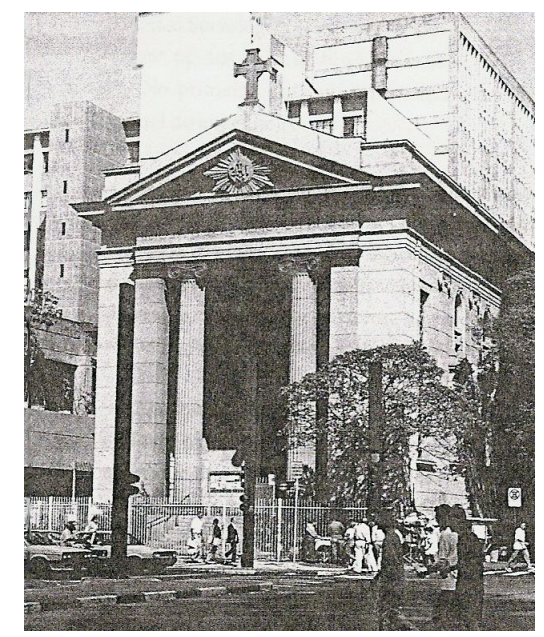

Fig. 4: Igreja São Luiz (Fonte: Os arquitetos da Poli).

\section{Aposentadoria}

Neste outro importante discurso por ocasião de sua aposentadoria compulsória (1961), Anhaia M ello novamente esbanjou seu conhecimento como homem de cultura sempre convicto do verdadeiro papel da Universidade, dizendo:

“Procurei sempre completar a educação e a formação espiritual de meus alunos com humanas verdades. Sei que não basta exercitar a inteligência e a memória. Sonhar, sentir e amar são elementos estruturais do espírito que devem ser cultivados e desenvolvidos com carinho. A tecnologia é um instrumento e não uma filosofia de vida. A técnica dá ao homem apenas o valor instrumental, mas só a cultura Ihe dá o valor humano. E esta é a missão primordial da Universidade - formar homens cultos e socialmente úteis que contribuam para solucionar os problemas regionais e nacionais, elevando o nível material e espiritual do povo, para que todos participem das alegrias e belezas essenciais da vida. Humanas verdades e não apenas mecanismos matemáticos e abstrações. Não há técnica sem ética. A ciência afirma, mas não escolhe. A máquina resolve, mas não pergunta. E é este suplemento de alma que a Humanidade esta precisando. No exercício de minha cátedra, insisti na formação global da personalidade do Engenheiro e do Arquiteto, interessando-os pelos problemas humanos, habilitando-os para o julgamento seguro dos problemas culturais, sociais e políticos, para que tivessem personalidade 
forte, espírito critico, sentido de solidariedade, abundância de ideais, coragem de afirmar seu amor à Terra e sua fé no Futuro. Todos devemos sentir o tormento da autenticidade. 0 homem não é apenas criador de formas, mas também criador de si mesmo. É autenticamente, um ser de desejo, de tensão, sempre insatisfeito. 0 homem satisfeito, sem inquietudes, sem sonhos, não é aquele que se encontrou, mas sim aquele que se perdeu". ${ }^{32}$

Assim, acreditamos ter destacado alguns dos pontos principais do pensamento de Anhaia Mello, personagem decisivo na formação profissional de Zenon Lotufo.

\subsection{Composição em arquitetura}

Neste ponto, faz-se oportuno conceituar melhor a relação entre composição na arquitetura clássica e seu ensinamento nos cursos tradicionais das Escolas de Belas-Artes, seu desenvolvimento e aplicação, uma vez que a disciplina da Composição Arquitetônica sempre fez parte da trajetória profissional e didática de Zenon Lotufo.

A idéia é investigar também o quanto seria verdadeira ou falsa a noção de rompimento com os valores tradicionais acadêmicos do passado,

proposta e divulgada no discurso dos arquitetos modernos. Para isso,

\footnotetext{
${ }^{32}$ Discurso proferido na Escola Politécnica da USP em 23 de agosto de 1961 in "Documentos sobre o urbanista Luiz Ignácio Romeiro de Anhaia M ello". FAUUSP, São Paulo, 1986.
}

escolhemos as reflexões dos teóricos e críticos Reyner Banham e Edson Mahfuz que se aprofundaram com bastante atenção nestas questões, argumentando e discutindo com profundidade o tema.

\section{Reyner Banham}

O influente crítico britânico Reyner Banham (1922-1988) em seu conhecido livro Teoria e projeto na primeira era da máquina, de 1960, traçou um panorama geral do movimento moderno e suas origens. Já no primeiro capítulo do livro, Banham discutiu a relação entre a tradição clássica francesa e a noção de composição elementar, através dos trabalhos de Julien Guadet (1834-1908), professor de grande respeito e, para Banham, o maior representante da tradição acadêmica da École des BeauX-Arts no final do século XIX.

Sua obra fundamental de cinco volumes Elements et Theories de I'Architecture (1902) procurou tornar a disciplina da composição arquitetônica tão racional, funcional e a-estilística quanto nenhum outro já havia feito. ${ }^{33}$

A valorização da composição, ou seja, a montagem do edifício a partir de suas partes e volumes mostrava que um edifício completo qualquer não

\footnotetext{
${ }^{33}$ Banham, Reyner. Teoria e projeto na primeira era da maquina. Editora Perspectiva. São Paulo, 2003, pg. 26.
} 
pode ser outra coisa senão o resultado da reunião de um número maior ou menor de partes.

0 problema era que o modo específico de reunir as partes é algo que Guadet, segundo Banham, discutia muito pouco, e por tanto, não era muito esclarecedor. 0 fato era que a disposição simétrica das partes de um edifício em relação a um ou mais eixos era o princípio diretor da arquitetura acadêmica de modo tão evidente que, segundo Guadet, não havia necessidade de discutí-lo.

Deixando de lado, por enquanto, o sentimento libertário de Guadet, em suas palavras vê-se uma atitude ambivalente e abstrata em relação à história, no sentido de compreendê-la e não imitá-la.

"Compor é usar aquilo que se conhece. A composição tem materiais, assim como os tem a construção, e estes materiais são justamente: os Elementos da Arquitetura. Na verdade, nada é mais atraente e sedutor do que a composição. É este o verdadeiro campo do artista. Compor, afinal o que é isso? É por juntas, unir, combinar as partes de um todo. Estas partes são os Elementos da Composição e assim como irão realizar suas concepções com paredes, aberturas, abóbadas e telhados - todos Elementos de Arquitetura - estabelecerão sua composição com quartos, vestíbulos, saídas e escadas - estes sim então os Elementos da Composição" ${ }^{34}$
Portanto, para Banham, a composição era o modo de reuní-los, onde os dois conceitos (composição/ reunião) formariam uma filosofia de projeto que seria comum tanto aos acadêmicos quanto aos ditos modernos, formados por esta mesma tradição.

A abordagem do assunto é particular, pequenos membros funcionais ou estruturais (Elementos de Arquitetura) seriam reunidos a fim de se obter volumes funcionais e estes por sua vez (Elementos de Composição) seriam reunidos de modo a gerar o edifício como um todo.

Fazer isto era compor no sentido literal e derivado da palavra, pôr junto. Assim, para Banham, podemos considerar como característica geral da arquitetura do começo do século XX, o fato dela ser concebida em termos de volumes separados para cada função, composta de tal modo que esta separação ficava claramente identificável.

\section{Julien Guadet}

O conjunto dos elementos de arquitetura e sua composição, presentes na obra de Julien Guadet (Éléments et Théories de L'Architecture) dividia-se em 16 livros, organizados em 2 partes, onde o objetivo principal era 0 estudo da composição arquitetônica, a partir destes elementos, e sua adaptação aos programas definidos e respectivas necessidades materiais. 


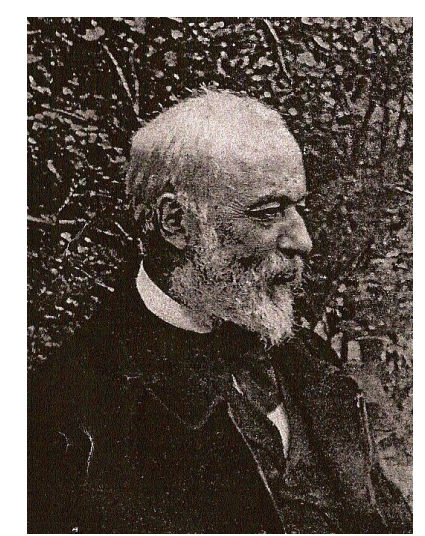

Fig. 5: Foto de Guadet (Fonte: Élemente e Teorie d'Architecture)

A primeira parte dedicava-se aos Elementos de Arquitetura propriamente ditos como: muros, ordens, arcadas, portas, janelas, seguidos por elementos mais complexos como salas, vestíbulos, varandas e escadas, entre outros. A segunda parte apresentava os princípios gerais de composição a partir do estudo dos principais gêneros de edifícios como, por exemplo, religiosos, civis, militares, públicos, habitacionais.

O primeiro Livro mencionava no seu primeiro capitulo, os estudos preparatórios do curso como matemática, geometria descritiva, traçado de sombras, noções de perspectiva, desenho e modelagem. A descrição dos instrumentos de desenho (réguas, compassos, esquadros, etc) ficou para o segundo capítulo, enquanto que os desenhos de Arquitetura (as escalas, a planta, o corte, a elevação, a necessidade de várias projeções para uma representação completa, os eixos, croquis à mão livre no papel quadriculado, etc) estavam no terceiro capítulo. Os capítulos 4 e 5 cuidaram dos modelos e sombras, e dos desenhos de imitação, forma e proporção, respectivamente.

Para o segundo Livro, Guadet aprofundou-se nos princípios gerais da composição reservando a discutir: lições introdutórias e programa geral (1‥ Capítulo), a Beleza na Arquitetura, o programa, local, terreno, situação e clima, verdade na construção e estabilidade dos materiais ( $2 \cong$. Capítulo), as grandes regras da composição (3‥ Capítulo) - (este capítulo será mais bem analisado posteriormente), as proporções gerais, definições, proporção racional e tradicional, responsabilidade do arquiteto, da proporção à composição (4ํ․ Capítulo), proporções específicas, arcadas, janelas, portas (50. Capítulo), proporção das salas, exigências higiênicas, entrada de luz natural (6ํ. Capitulo), corolário de estudo das proporções em plantas, cortes e elevações e a dependência recíproca entre elas (70 capitulo); a arte e a ciência da construção -

"Arquitetura é construção; e construção é uma arte e uma ciência. Arte pela invenção, combinação e previsão; e Ciência pelo controle, rigor e verificação". ${ }^{35}$

Nos terceiro, quarto e quinto livros, o foco passa a ser os Elementos da Arquitetura e, portanto seguem a ordem referida: muros, aberturas,

\footnotetext{
${ }^{35}$ Guadet, J. Elements et Theorie de lÁrchitecture (cours professé á I'École Nationale et Spéciale des Beaux-Arts). Librarie de la construction moderne, Paris, 1909 (3ä. edição original da Biblioteca da Escola Politécnica), pg 194.
} 
portas, janelas, decoração (Livro 3); pórticos e ordens (Livro 4) e telhados, coberturas, tetos e escadas (Livro 5), encerrando o primeiro volume da obra de Guadet.

0 segundo volume (correspondente aos livros de 6 a 9) apresentava os Elementos de Composição (principiais tipologias de uso) como:

habitações (Livro 6), escolas primárias, liceus, colégios, ensino superior, científicos, museus e bibliotecas (Livro 7), edifícios públicos administrativos, judiciais e penitenciárias (Livro 8) e hospitais (Livro 9). 0 terceiro volume abrangia os livros 10 a 12 onde estavam os edifícios públicos comerciais, mercados, alimentação, termas e teatros (Livro 10), edifícios religiosos, igrejas e respectiva ornamentação (Livro 11), e edifícios funerários, comemorativos e decorativos (Livro 12).

0 último (e quarto) volume da obra fundamental de Julien Guadet compunha-se pelos livros de 13 a 16 onde se situava: monumentos, fontanas, praças, pontes e aquedutos (Livro 13); arquitetura rural, militar e jardins (Livro 14); considerações gerais da composição (Livro 15); e profissão do arquiteto, designações, projeto executivo, direção de obra, honorários e responsabilidades (Livro 16).

Concentramos nossa atenção principalmente na análise do capítulo III do segundo livro, intitulado "Lês grandes regles de la composition" (As grandes regras da composição) ${ }^{36}$, uma vez que nele encontram-se as principais diretrizes e conceitos a serem aplicados na Arte de se compor a Arquitetura.

Neste capitulo, Guadet destacava em linhas gerais os aspectos a serem observados e estudados com atenção, como comentamos a seguir:

\section{Superficies úteis}

Em primeiro lugar, o destaque era para Les surfaces utiles et les circulations (Superfícies úteis e circulação) onde dado qualquer programa, este se dividiria em duas partes distintas: as partes habitáveis, ou seja, as células, quartos, salas e salões (superfícies úteis) e as comunicações necessárias para acessá-las, ou seja, os corredores, galerias, ante-salas e escadas (circulações horizontais e verticais). Em outras palavras, Guadet reforçava a importância de se pensar a circulação entre os ambientes da maneira mais eficiente e útil possível, sem desperdícios (esta era uma das principais preocupações de Zenon Lotufo na hora de projetar, segundo seu filho Vitor).

“Em geral, a principal dificuldade da composição é permitir que se circule facilmente por todas as peças, que todas as partes estejam comodamente ligadas; se os meios encontrados forem simples, a planta será clara e facilmente compreendida e seguida. Garantam, portanto, as

\footnotetext{
${ }^{36}$ Traduzido para português pela prof. Maria Amália Ramos.
} 
comunicações, mas sem abusar de pórticos, galerias, etc. E é nisso, principalmente, que vocês reconhecerão a simplicidade como uma qualidade preciosa da composição. Simplicidade, simplicidade sempre!". 37 Guadet também afirmava que uma boa composição ofereceria as condições para uma planta racional de telhado onde as águas deveriam ser facilmente escoadas, e a planta do pavimento térreo já pressupunha isto. E procurava resumir o processo compositivo como uma seqüência de escolhas e sacrifícios em que não se deveria simplesmente seguir regras, mas sim o bom senso a partir do profundo conhecimento das necessidades dos usuários.

\section{Beleza}

“Mas não é tudo. Não visamos apenas o útil. Um povo que só visse dentro da arquitetura o útil, sem buscar também o belo, renunciaria a toda civilização". ${ }^{38}$

Desta forma, Guadet instruía que uma bela composição deveria ser antes de tudo: boa. Assim, cada sala seria completada pelo efeito das demais, se planejadas em belas seqüências; e se os pátios forem prolongados por perspectivas bem planificadas; e se em suas fachadas, se colocar belas sacadas ou recuos ou pavilhões acentuados, enfim se tudo isso for variado, e se colocar oposições, até mesmo contrastes.

\footnotetext{
${ }^{37}$ Guadet, Opt. Cit., pg. 117.

${ }^{38}$ Guadet, Opt. Cit., pg. 124.
}

\section{A simetria, a boa planta e o pitoresco}

Guadet revelava que a simetria - junto com a variedade - deveria em geral ser sempre buscada, pois a simetria seria a regularidade daquilo que deve ser visto num só lance de olhar, a regularidade inteligente. A simetria seria incontestavelmente uma beleza e raras vezes a composição poderia renunciar a ela sem perdas. Seria, portanto um componente muito importante da composição.

Outra questão discutida foi a expressão "uma bela planta" seria uma expressão concisa, que é preciso entender como uma planta que permite e promete belas coisas, belos interiores e belas fachadas.

Guadet abordou também o pitoresco; que segundo ele se compõe sozinho pela ação do maior dos artistas: o tempo. Não deveria ser procurado, só assim, talvez, se conseguiria alcançá-lo.

Mas, em suma, o que é o pitoresco? A variedade. Mas não existe uma variedade que depende de nós, arquitetos, que nós podemos e, portanto devemos garantir?

Essa variedade legítima nada mais seria do que o caráter, uma identidade entre a impressão arquitetural e a impressão moral do projeto.

“Existe, sem dúvida, uma beleza intrínseca da arquitetura; e admiramos vestígios soberbos de monumentos cuja destinação nós ignoramos. Mas a beleza não é uma qualidade banal, e sua busca não tem o direito de ignorar o caráter da edificação. As formas magníficas de um 
palácio a plicadas a uma prisão seriam ridículas; aplicadas a uma escola, a uma construção industrial, também estariam deslocadas". ${ }^{39}$

O caráter dos edifícios é a condição de sua diversidade, e preserva uma cidade ou uma época da monotonia das demais edificações. 0 arquiteto deve se necessário, agir com abnegação e resistir também à tentação. $E$ isso não deve surpreender, é a confirmação de uma lei histórica. Desde o Cristianismo, o homem tornou-se mais diverso, mais complicado também: não vamos lamentar, pois a variedade do caráter em nossos edifícios é uma atração e uma riqueza a mais dentro da linguagem arquitetônica.

\section{Tradição}

Enfim, Guadet afirmou que para sustentar e guiar seus alunos haveria também a tradição. Ora, essa atitude significa considerar dignos os longos esforços, continuados através dos séculos pelas gerações que nos precederam.

“Em geral, demonstra ignorância aquele que finge desdenhar o que não conhece, para não precisar fazer o esforço necessário para conhecê-lo. Não tenham essa presunção. 0 progresso é coisa lenta e deve ser coisa segura. Chi va piano va sano, chi va sano va lontano.Vocês

\footnotetext{
${ }^{39}$ Guadet, Opt. Cit., pg. 133.
}

sabem o que é muito forte, e muito original? É fazer muito bem aquilo que outros fizeram simplesmente bem". ${ }^{40}$

Concluindo, Guadet relatava que as mais belas épocas da arte foram aquelas em que a tradição era mais respeitada, onde o progresso era um aperfeiçoamento contínuo, uma evolução, e não uma revolução. Nunca houve geração espontânea em arte: entre o Partenon e os templos que o precederam, só haveria nuances. A tradição seria um patrimônio paterno: se abandonado sem prudência, arriscava-se a ficar entregue ao acaso.

Assim, verificamos algumas das lições deixadas por Guadet sobre as principais regras na composição arquitetônica que influenciaram gerações de estudantes do curso da Ecole de Beaux-arts de Paris, tornando-se referência também em outros países, no começo do século XX, refletindo também sobre o curso de Engenheiro-Arquiteto da Politécnica de São Paulo.

\section{Edson Mahfuz e a razão compositiva}

O livro Ensaio sobre a razão compositiva ${ }^{41}$ do arquiteto e professor Edson da Cunha Mahfuz também investigou o processo de projeto como uma combinação de relações possíveis entre as partes e o todo arquitetônico.

\footnotetext{
${ }^{40}$ Guadet, Opt. Cit., pg. 134.

${ }^{41}$ Mahfuz, E. Ensaio sobre a razão compositiva. Editora UFV/AP Cultural, Belo horizonte, 1995.
} 
Durante a maior parte do século passado, segundo M ahfuz, o termo composição teve uma conotação negativa, pois estava associado à tradição acadêmica de imitação estilística, que o M ovimento Moderno se opunha ou tentava superar. Composição seria, portanto na acepção acadêmica, 0 arranjo das partes da arquitetura como elementos de uma sintaxe, de acordo com certas regras a priori, de modo a formar um todo. Assim, o método Beaux-Arts baseava-se na idéia tradicional das teorias arquitetônicas do Renascimento: o processo de composição arquitetônica evolui do todo para as partes, ou seja, o todo viria antes das partes.

Portanto, gerava-se primeiro o todo e depois, projetava-se as partes de acordo com aquele pré-conceito. Assim, as partes de um edifício deveriam estar subordinadas a um aspecto principal (príncipe), devendo adaptar-se a ele.

O primeiro passo no método Beaux-Arts era o desenvolvimento de um príncipe; que vem a ser a concepção mais básica de um edifício, ou seja, um esquema diagramático, uma idéia conceitual genérica. Depois desta definição, segue-se o desenvolvimento do estudo onde ficam definidas as características principais do projeto.

Segundo Mahfuz, a passagem para o plano material dar-se-ia em um plano intermediário que corresponde ao desenvolvimento do todo conceitual também chamado de partido. 0 partido fixaria a concepção básica (essência) do projeto em termos de organização plani-altimétrica e volumétrica, assim como suas possibilidades estruturais e de relação com o contexto.

\section{Tratados modernos}

Os tratados modernos de arquitetura a partir do Renascimento surgiram com Leone Battista Alberti (1404-1472) e sua obra De Re Aedificatoria (1452) do século XV. Segundo Alberti, existiria um problema na definição da parte arquitetônica que seria primeiro uma questão da escala e segundo uma questão dos limites.

Assim, Alberti definiu a parte como algo com conteúdo espacial definido (recinto) onde as partes principais seriam os espaços interiores e exteriores de um edifício, com demarcação específica e separação das áreas (pórtico, vestíbulo, pátio, salão) e as partes secundárias por sua vez dariam o caráter às partes principais, ou seja, os detalhes arquitetônicos (portas, janelas, as Ordens, etc).

Por sua vez, entre os séculos XVIII e XIX, o francês J ean-Nicholas-Louis Durand (1760-1834) foi o professor da Escola Politécnica de Paris (criada em 1795) que propôs mudanças revolucionárias na maneira de ensinar arquitetura, focalizando sua prática nos valores utilitários e econômicos, de modo a assegurar os princípios racionais clássicos: beleza, proporção e simbolismo. Sua sistematização de planos/ elevações/ seções transformou efetivamente o projeto de arquitetura em uma seleção de 
tipologias onde a simetria e a simplicidade das formas geométricas prevaleciam, definindo-o como um sistema racional e formal, de caráter subjetivo, lógico e fechado, ao mesmo tempo. ${ }^{42}$

Seu livro Précis des Leçons d' Architecture (1802-05) consistia na combinação de elementos (partes) precisamente definidos onde havia uma distinção entre elementos construtivos - fundação, paredes, tetos e as partes dos edifícios divididas entre principais: pórticos, vestíbulos, pátios e demais recintos - e acessórias: escadas, pérgolas, etc. Sua principal preocupação era oferecer uma espécie de catálogo onde qualquer projetista poderia escolher as partes e agrupá-las seguindo as instruções de como reuní-las.

A estrutura do texto se organizava em dois volumes onde o primeiro tratava dos Elementos do Edifício (qualidades e usos dos materiais, formas e proporções) e da Composição em Geral (combinação de elementos, partes do edifício e seu todo).

O segundo volume encarregava-se de examinar os principais tipos de edifícios, agrupando-os em: urbanísticos (portais, arcos, ruas, pontes e praças), edifícios públicos (templos, palácios, tribunais, escolas, bibliotecas, museus, mercados, matadouros, teatros, balneários, hospitais

${ }^{42}$ Durand, J-N-P. Precis of the Lectures on Architecture (1802-05). Traduzido em inglês por David Britt. The Getty Research Institute. Los Angeles, 2000. e penitenciárias) e edifícios privados (casas, apartamentos, dependências, hospedarias, etc).

Para Antoine Picon, que abre a introdução do livro (traduzido para o inglês em 2000), a metodologia de Durand sobreviveu por gerações de estudantes ao longo do século XIX, pois teria sido o primeiro tratado subjetivo de arquitetura. Ele teria sido pioneiro em definir o processo arquitetônico com foco na metodologia de projeto, onde aplicava um princípio comparativo, em uma escala constante, entre os diferentes tipos de edifícios, ao longo da história da arquitetura, justapondo: templos, fóruns, basílicas, teatros, bibliotecas, etc.

Para Picon, o grande desafio de Durand foi confrontar a possibilidade de manter a arquitetura como disciplina autônoma com a racionalidade científica que predominava naquela época, numa Escola que educava engenheiros e cientistas, cujo objetivo era basicamente transmitir-Ihes conhecimento tecnológico.

No final da segunda parte do livro, Durand conclui com o texto The Procedure to be followed in the composition of any Project (Procedimentos a serem seguidos na composição de qualquer projeto) onde relata (dirigindo-se aos estudantes) uma seqüência lógica para se combinar os diferentes elementos e partes do edifício.

"Antes de tudo, certifique-se que você compreendeu o uso e as necessidades do edifício a ser projetado; atente-se para o espírito daquilo 
que será concebido e certifique-se que qualidades como solidez, salubridade, conforto, segurança e tranqüilidade transparecerão. Depois disso, considere a hierarquia entre as partes, ou seja, quais salas são principais, quais são secundárias; estabelecendo suas posições e tamanhos. Uma vez feita estas observações (em croquis), determine 0 número de eixos em cada sala, descobrindo o total deles em relação a superfície do terreno (fundação) e a estrutura possível (vãos técnicos). Um estudo feito desta maneira, se ajustará facilmente aos ornamentos artísticos que serão empregados posteriormente. Assim, é fácil de observar com que facilidade e sucesso, qualquer edifício pode ser composto, se 0 arquiteto, seguir o curso indicado pela razão e pelos princípios derivados da natureza, ambos presente no estudo da arte e da composição, onde se trata de (nada mais e nada menos) uma sucessão continua de observações e raciocínios". ${ }^{43}$

A noção tipológica de Durand não seria um catálogo de soluções aplicáveis, mas um sistema classificatório que familiarizasse qualquer pessoa com os vários problemas que viessem a ocorrer na prática projetual. 0 tipo seria definido, portanto, segundo Durand, como uma espécie de subsistema baseado na associação entre função, uso e arranjos espaciais entre eixos. Sua coerência e estabilidade derivam de

\footnotetext{
${ }^{43}$ Durand, J-N-P. Opt. Cit., p. 180-181.
}

uma economia interna, o que permite a formação de uma matriz que orienta a concepção do edifício, sem confiná-lo na imitação de um modelo. ${ }^{44}$

Na recapitulação do prefácio, Durand definiu:

"Arquitetura é uma arte única em que seu objeto é a composição e execução de edifícios, tanto público com privado, e seu propósito é satisfazer a maior parte de nossas necessidades, e de colocar-nos numa posição capaz de preencher todas as outras". ${ }^{45}$

Segundo Durand, os meios para se alcançar este fim seriam ajuste (fitness) e economia. Ajuste indicaria solidez, salubridade e conforto. E por sua vez, economia compreenderia simetria, regularidade e simplicidade. Solidez dependeria da seleção e do uso dos materiais e do número e disposição dos suportes, e salubridade dependeria da situação, da exposição, da elevação do solo, das paredes e suas aberturas e da cobertura. Conforto viria da relação entre a forma do edifício e o número de partes, de um lado, e seus propósitos, de outro.

Quanto à economia, as mais simétricas, regulares e simples formas como o círculo, o quadrado, seriam as mais econômicas pois seus perímetros definiriam áreas mais precisas.

\footnotetext{
${ }^{44}$ Durand, J-N-P. Opt. Cit., p. 47.

${ }^{45}$ Durand, J-N-P. Opt. Cit., p. 87.
} 
E na sua conclusão, disposição deveria ser a única preocupação do arquiteto, e sua finalidade seria oferecer deleite. Caráter, efeito, variedade - ou seja, os aspectos estéticos que se pretende dar a um edifício através da decoração - naturalmente apareceriam em qualquer disposição que abrangesse ajuste (fitness) e economia. Portanto, antes de se dispor um edifício, combinando e reunindo suas partes, estas etapas precisariam ser conhecidas.

A seguir, investigamos também a origem do chamado método Beaux$\operatorname{arts}^{46}$, de modo a caracterizá-lo com mais profundidade, na tentativa de

${ }^{46}$ O método Beaux-arts baseava-se na solução de problemas de composição, ou seja, na organização dos elementos arquitetônicos de acordo com princípios compositivos (unidade, proporção, escala, harmonia) para daí extrair uma formulação sobre o caráter do edifício. Baseava-se principalmente na relação mestre-aprendiz que se efetivava no âmbito do atelier, onde o aluno dependia da competência de projetar do professor para o seu desenvolvimento e amadurecimento no processo de projeto. A noção de composição remonta à tradição renascentista quando os tratadistas (leia-se principalmente, Alberti e Palladio) estabeleceram normas e princípios que seriam capazes de traduzir a idéia de Beleza. Mais precisamente, nos séculos XVIII e XIX, teóricos das escolas de arquitetura francesa, as École dês Beaux-arts, influenciaram a noção de composição arquitetônica, formulando as bases para a realização da boa estabelecer as relações com os trabalhos de Guadet e Durand e conseqüentemente com o curso de Composição da Escola Politécnica de São Paulo.

\section{Origem e aplicação do método Beaux-arts}

A implantação da política cultural iluminista do Estado Francês, na forma de academias, desvirtuou o ideal humanista da Renascença. Nela houve lugar tanto para a imposição de uma nova síntese de arquitetura, escultura e pintura - as Beaux-Arts -, quanto para uma completa instrumentação do conhecimento. Essas duas tendências terão expressão, respectivamente, na École de Beaux-Arts e na École Polytechnique de

arquitetura.A composição como técnica ou método de ensino Beaux-arts fundamentava-se na interpretação das teorias renascentistas e clássicas, segundo as quais, os elementos de uma edificação estariam subordinados a um aspecto principal ("príncipe"), tendo como objetivo chegar a unidade e harmonia da obra. 0 método era bastante claro e estabelecia as ações necessárias para se chegar ao projeto final: 1) Desenvolvimento do partido ("parti pris") - esquema conceitual básico definido a partir de esquemas tipológicos tradicionais, previamente assimilados na mente do projetista; 2) Estudo aprofundado ("esquise") definição das características gerais do edifício, com maior precisão; 3) Desenhos finais ("rendu") - tratamento requintado e fiel ao "esquise" original. 
Paris, tanto que se tornaram modelos para o ensino de arquitetura de um modo geral no ocidente. ${ }^{47}$

No Brasil, assim como nos Estados Unidos, a influência da École des Beaux-Arts foi definitiva. Entretanto há diferenças fundamentais a serem consideradas no modo como essa influência modificou o ensino e a prática da arquitetura nos dois países. Nos Estados Unidos, a tradição Beaux-Arts se deu também via ensino de engenharia. Dessa forma, 0 ensino americano, bem como na Alemanha e Espanha, herdaram a tradição "politecnista" que considerava a arquitetura uma especialidade da engenharia.

Já no Brasil, a tradição Beaux-Arts chegaria de duas formas: diretamente, via missão francesa e, indiretamente, via escolas de engenharia. A tradição Beaux-Arts "pura" se desenvolve numa seqüência de instituições. Inaugurada no Rio de Janeiro em 1816, como "Escola Real de Ciências, Artes e Ofícios", ela passa por várias fases, desde "Real Academia de Desenho, Pintura, Escultura e Arquitetura Civil", "Imperial Academia de Belas-Artes", "Escola Nacional de Belas-Artes", até se transformar em "Faculdade Nacional de Arquitetura", em 1945. Por sua vez, os cursos de

\footnotetext{
${ }^{47}$ Trecho extraído do artigo eletrônico Disciplina e Legitimação do Conhecimento de Roberto Eustáquio dos Santos em:

४ttp:// www.arquitetura.ufmg.br/ia/disciplinalegitimidade.html>
}

Engenheiro-Arquiteto, fundados em São Paulo e no Rio Grande do Sul, seguiram um modelo similar ao americano.

Segundo Santos, embora o prestígio "acadêmico" estivesse mais ligado à tradição Beaux-Arts (que até 1945 tinha o curso de arquitetura ligado estreitamente aos cursos de pintura e de escultura, ou seja, à noção francesa de Belas-Artes) é o modelo inspirado na transformação ocorrida dentro da tradição politécnica (que passa a considerar a arquitetura como um ramo da engenharia) que prevaleceu no ensino brasileiro.

Sigfried Giedion em seu livro Espaço, Tempo e Arquitetura discorreu sobre outro fator importante: a cisão entre a arquitetura e a tecnologia no decorrer do século XIX. Segundo ele, este fato decorrera da existência e também da controvérsia entre as linhas de atuação da Ecole de BeauxArts e da Ecole Polytechnique de Paris. ${ }^{48}$

Em 1806, Napoleão fundara a Ecole de Beaux-Arts cujo programa mantinha a unidade entre a arquitetura e as demais artes. A Ecole Polytechnique por sua vez havia sido fundada em 1794, oferecendo uma formação científica em relação as escolas técnicas avançadas. Grandes teóricos, físicos e matemáticos da França que atuavam na Ecole influenciaram diretamente e decisivamente a indústria, combinando ciência teórica e prática.

\footnotetext{
${ }^{48}$ Giedion, S. Espaço, tempo e arquitetura. Editora M artins Fontes, São Paulo, 2004, pg. 237.
} 
Assim, a tentativa da escola politécnica era estabelecer a articulação entre ciência e vida, com o intuito de trazer aplicações práticas de descobertas científicas e matemáticas para o desenvolvimento da indústria.

A pergunta que se seguia era: que tipo de formação deveria seguir um arquiteto? E afinal, qual a relação e a diferença entre um engenheiro e um arquiteto?

Os sistemas construtivos deveriam influenciar o caráter do projeto de um edifício e assim cada vez mais o engenheiro passava a interferir no campo de atuação do arquiteto.

As novas invenções técnicas impunham ao arquiteto o dever de explorar novos caminhos e alternativas. Assim, uma das principais funções da técnica construtiva era também fornecer à arquitetura, o estímulo e 0 incentivo para os novos avanços.

A menção dos fatos anteriores interessa no sentido de construir um quadro histórico mais amplo e estabelecer pontes entre o ensino no curso de Engenheiro-Arquiteto da Politécnica de São Paulo e a formação acadêmica de Zenon Lotufo. Deste modo, passamos a registrar alguns dos trabalhos realizados por Zenon, e também de alguns colegas de curso, de forma a ilustrar o repertório estético e arquitetônico clássico da Escola.

\section{5. - Trabalhos de Composição}

Os melhores trabalhos eram periodicamente publicados pela Revista do Grêmio Politécnico, veículo de circulação acadêmica que incentivava o esforço e a dedicação dos alunos de modo que todos desejavam participar com seus desenhos das páginas do periódico.

Zenon Lotufo teve a oportunidade de publicar cinco trabalhos sendo importante destacar nos exemplos a seguir a riqueza dos temas (fig. 6 Lanterna de Demóstenes; fig. 7 - Igreja em estilo gótico e fig. 8 - edifício Residencial), todos datados de 1935, durante o 4‥ ano de curso para a disciplina Composição Geral.

No quinto ano de curso de Zenon, o periódico acadêmico publicou 0 projeto para uma estação ferroviária (fig. 9), além de seu trabalho de conclusão.

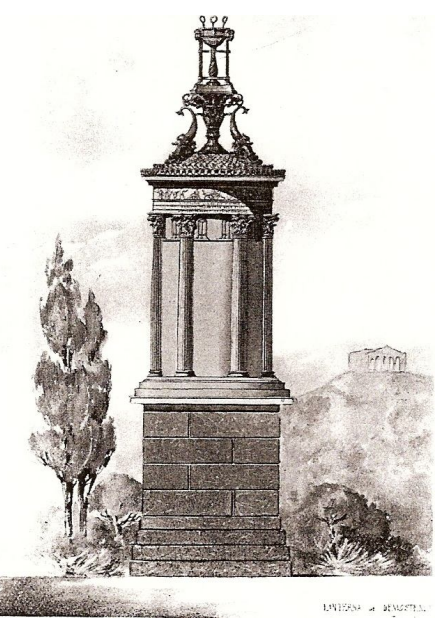

(fig. 6) Fonte: RGP n.119 


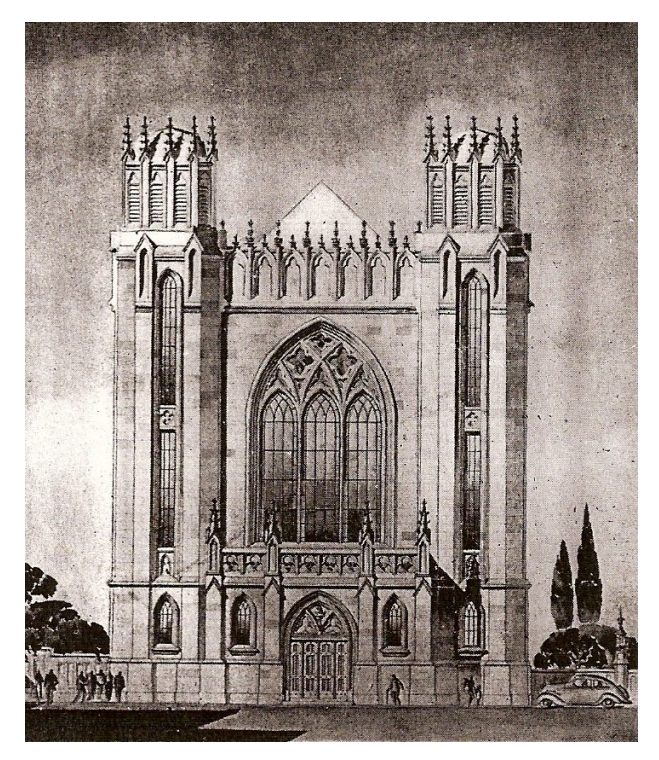

(fig. 7) Fonte: RGP n.120.

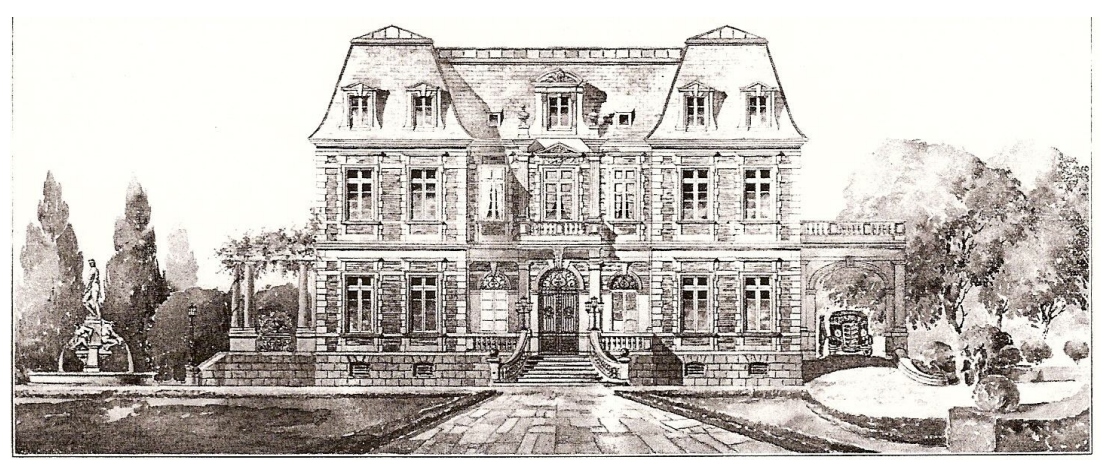

(fig. 8) Fonte: Revista Grêmio Politécnico n. 121 (RGP).

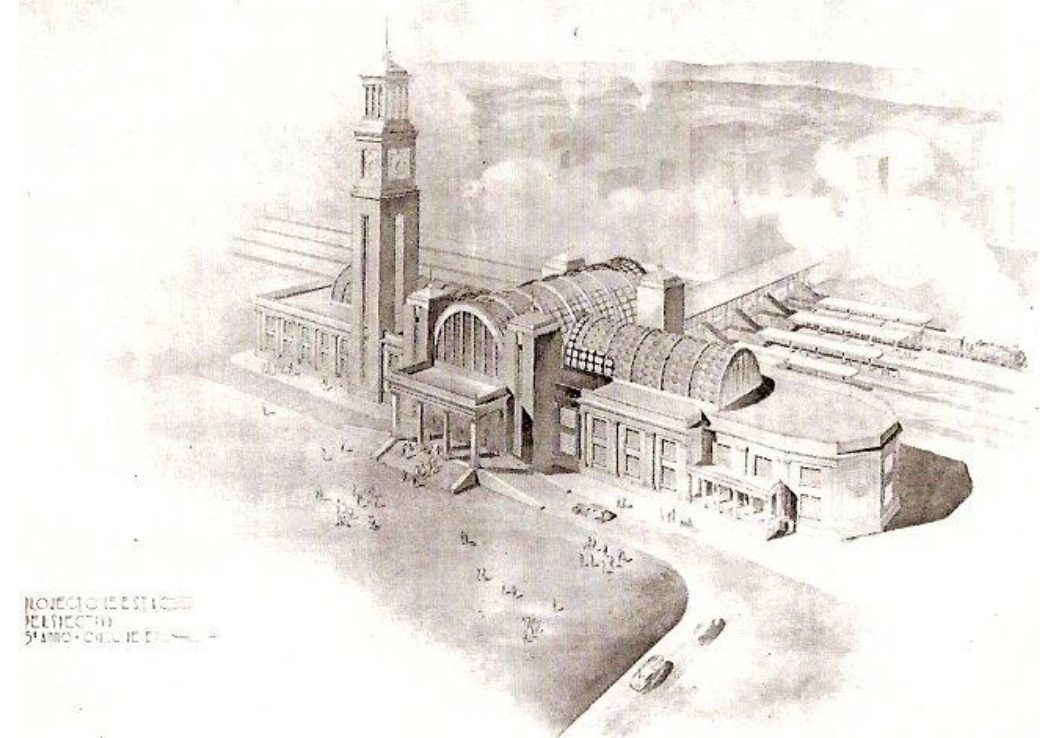

(fig. 9) Fonte: Revista Grêmio Politécnico 125 (RGP).

Em 1936, Zenon Lotufo forma-se Engenheiro-Arquiteto pela Escola Politécnica da Universidade de São Paulo. Seu trabalho de conclusão de curso, um edifício de apartamentos (fig. 10) já apresentava certa transição moderna ao preferir linhas mais ortogonais e limpeza nos volumes da composição. Tal fato comprovaria uma sintonia do jovem arquiteto com os processos de mudança na disciplina arquitetônica da década de 30 . Certa ruptura com os estilos tradicionais (ornamentação controlada), mas ao mesmo tempo uma aceitação de valores clássicos como simetria, equilíbrio e proporção. Interessante também é comparar a semelhança da torre de apartamento com o Edifício Columbus (projeto de Rino Levi - 
projeto de 1930 e construção terminou em 34), obra inovadora na época que situava-se à Rua Brigadeiro Luis Antonio (já demolido), como mostramos abaixo.

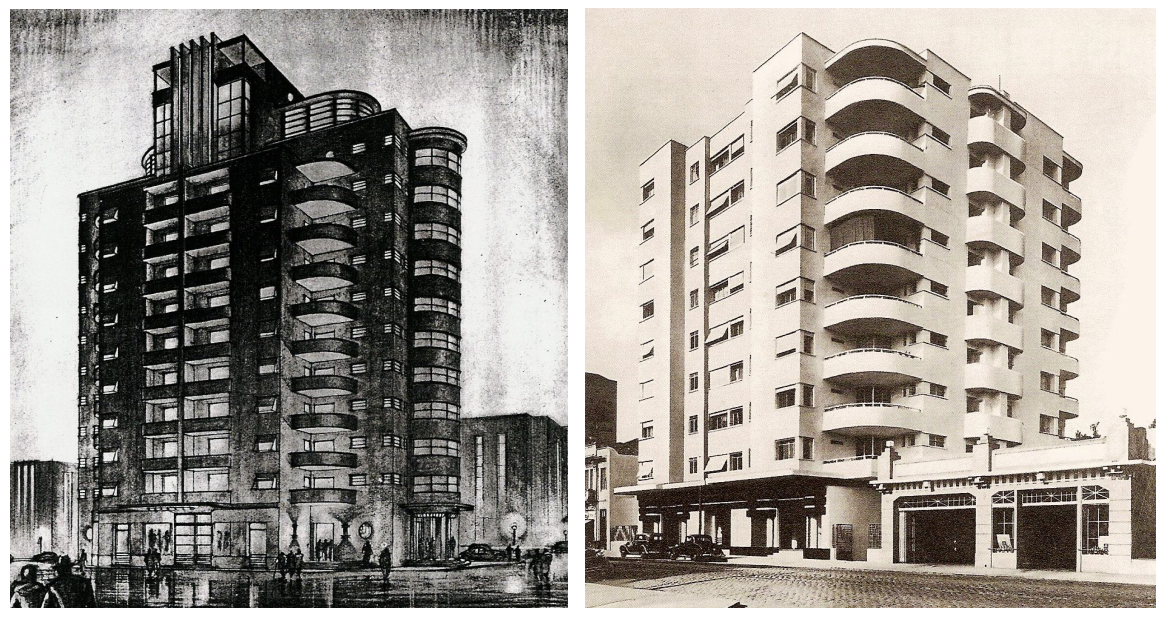

(Figs. 10 e 11): Trabalho de conclusão de curso de Zenon Lotufo, ao lado, foto de época do edifício Columbus, autoria de Rino Levi. Fontes: RGP 122 e Rino Levi - Arquitetura e Cidade.

\section{Trabalhos de colegas}

Zenon Lotufo se formou como único engenheiro-arquiteto no ano de 1936, ou seja, na metade da década de 30 . Isto quer dizer que seus colegas de outros anos (do primeiro ao quinto) com quem tivesse convivido ou acompanhado, teriam freqüentado as aulas do curso de engenheiro-arquiteto nesta faixa de tempo (cinco anos antes do ingresso de Zenon (30) e cinco anos depois de sua formatura (40).
Assim, podemos comparar os trabalhos de Composição dos colegas que conviveram no mesmo período que Zenon esteve na faculdade, fato que poderia comprovar o repertório plástico dos alunos, estilos, linguagem e técnica gráfica, entre outros, e também ilustrar certo padrão estético no ensino da Politécnica.

A lista de formados de 30-41 totaliza um número de 41 engenheiros arquitetos. Entre os nomes mais conhecidos podemos mencionar: Carlos da Silva Prado (32), Carlos Brasil Lodi (33), Affonso lervolino e Mário Edgard Henrique Pucci (34), Icaro de Castro M ello (35), João Batista Vilanova Artigas (37), Rubens Gouvêa Carneiro Vianna (38), Leo Ribeiro de Moraes (39), Roberto Cerqueira César e Ariosto Mila (40) e Oswaldo Correa Gonçalves $(41)^{49}$. Alguns destes trabalhos reproduzimos a seguir.

\footnotetext{
${ }^{49}$ Catálogo de exposição - 100 anos de Ensino de Arquitetura e Urbanismo em São Paulo, setembro de 1996, coord. Nestor Goulart Reis, p. 93.
} 


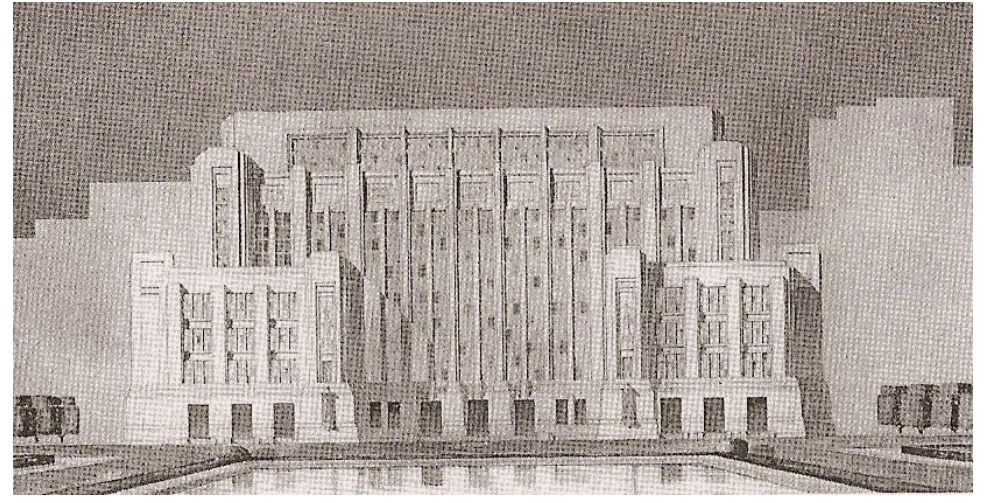

Fig. 12: Trabalho de Alfredo Giglio (50. Ano - 1935) Fonte: RGP. Interessante observar nos desenhos, os temas programáticos de composição, a semelhança na linguagem e técnica gráfica de representação (céu esfumaçado e escuro, massas de vegetação, sombras, reflexos nos vidros), além do predomínio da temática clássica: simetria, proporção, harmonia e ritmo do conjunto.

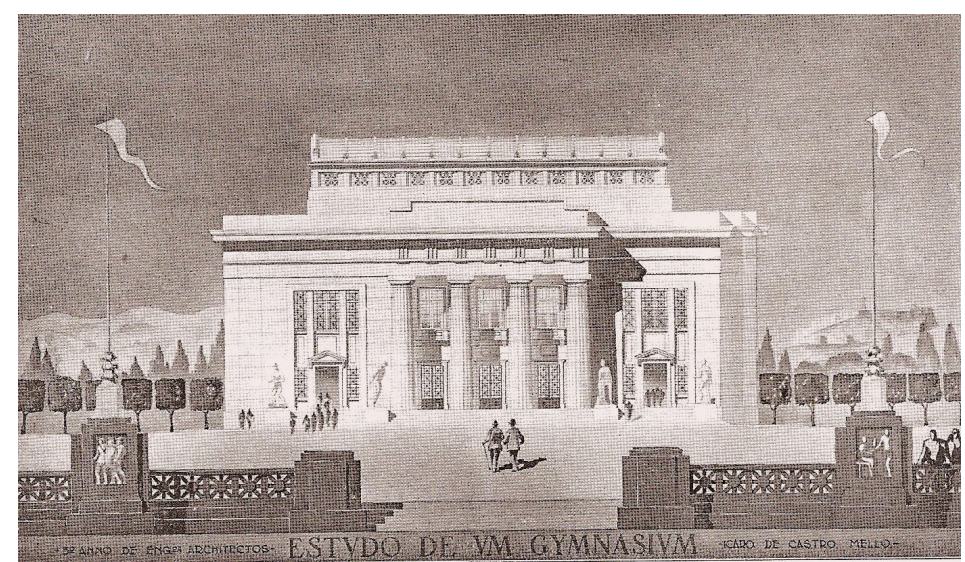

Fig. 13: Estudo de Ginásio de İcaro de Castro M ello (50. Ano - 1935). Fonte: RGP.
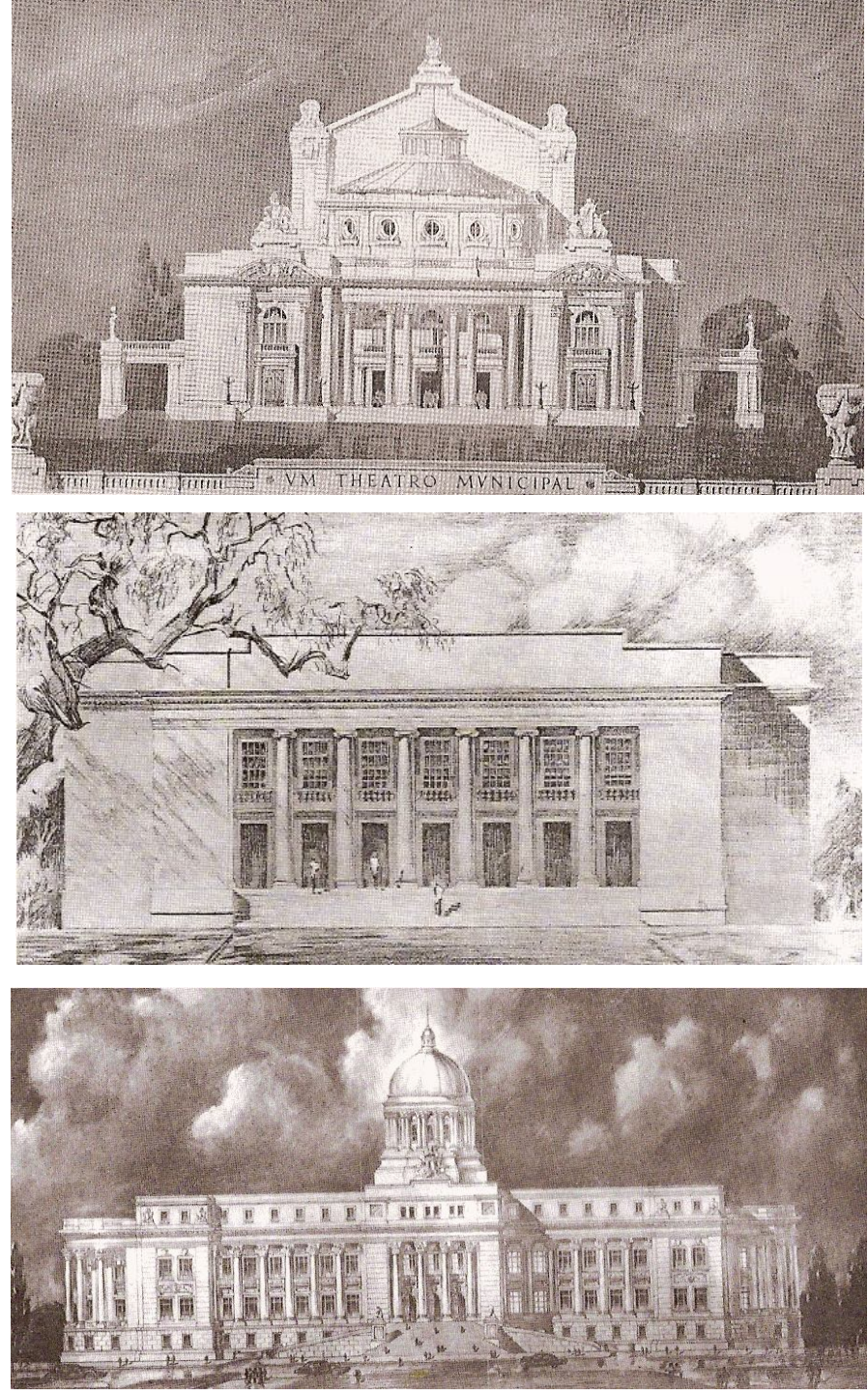

Figs. 14 a 16: Trabalhos de Afonso lervolino (5‥ Ano - 1934), Roberto Cerqueira Cezar (3‥ Ano - 1938) e Rubens Carneiro Vianna (50 ano - 1938). Fonte: RGP. 
João Batista Vilanova Artigas também fora aluno do curso de EngenheiroArquiteto da Escola Politécnica, no período de 32 a 37. No livro editado pela sua fundação em 1997, consta um relato de sua vida na introdução onde 0 arquiteto abordou sobre sua estrutura de funcionamento:

"O curso de Arquitetura, na Escola Politécnica, era, no fundo, um curso de Engenharia Civil que incluía um programa de Pequenas e Grandes Composições, como se fizera nas Belas Artes. Depois tínhamos aulas de história da Arquitetura e uma cadeira de Estética e Urbanismo, que era o Anhaia Mello quem dava, para 0 4․ e 5‥ Anos. As Pequenas e Grandes Composições tratavam da parte compositiva, por assim dizer, de criação artística ou estética." ${ }^{50}$

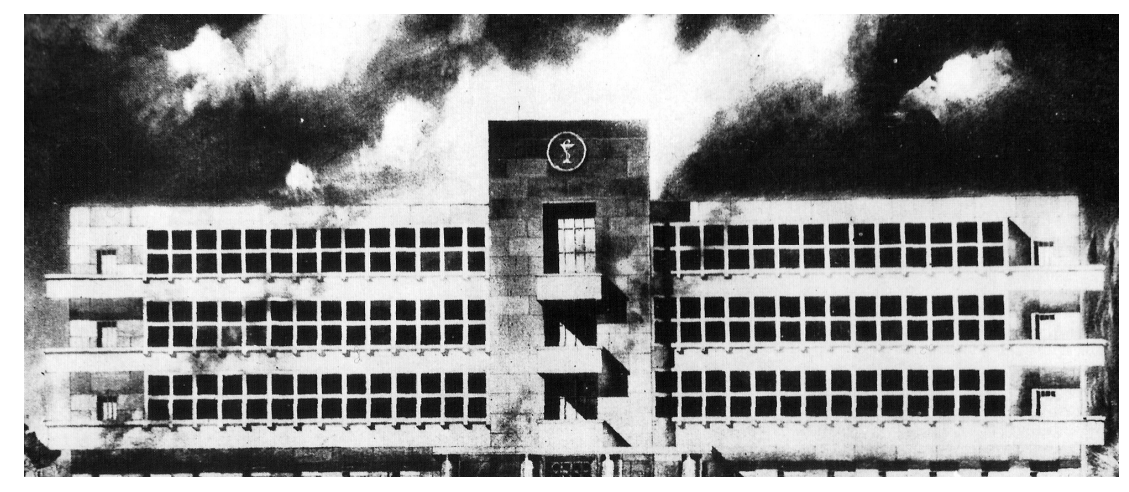

Fig. 17: Trabalho de Composição de Vilanova Artigas Fonte: Vilanova Artigas: arquitetos brasileiros.

\footnotetext{
${ }^{50}$ Instituto Lina Bo e P.M. Bardi e Fundação Vilanova Artigas. Vilanova Artigas: arquitetos brasileiros. São Paulo, 1997, pg. 17.
}

\section{Contexto profissional em São Paulo}

Na década de 30, os nomes da arquitetura paulista que despontavam eram Rino Levi, Flávio de Carvalho e Gregori Warchavick, todos com formação européia travando sozinhos, uma batalha pela aplicação da nova linguagem moderna em São Paulo.

O ensino universitário limitava-se naquela época apenas ao curso de Engenheiro-Arquiteto dado pela Escola Politécnica, cuja especialidade era atribuída apenas aos alunos que assim a optassem, a partir do terceiro ano, como vimos anteriormente.

No entanto, o negócio da construção em São Paulo (até a década de 40) limitava-se basicamente às firmas particulares, conhecidas como escritórios técnicos, que cuidavam de todas as etapas necessárias à obra: projeto, orçamento e execução.

Arquitetura e engenharia não se distinguiam muito neste período, existindo apenas algum tipo de subdivisão no interior dos escritórios técnicos, de modo que não existiam firmas especializadas apenas na realização dos projetos, uma vez que no valor da construção, este já estava incluído.

Outro setor que absorvia os profissionais da construção civil era o serviço público graças à quantidade de obras de infra-estrutura urbana como pontes, estradas, escolas, etc. Como exemplo, poderíamos citar a Secretaria de Obras Públicas e Viação da Prefeitura de São Paulo (onde 
Zenon Lotufo chegou a trabalhar primeiro como desenhista e depois como engenheiro-arquiteto contratado)

Nesta época, o diretor da escola de engenharia M ackenzie, Arquiteto Christiano Stockler das Neves defendia duramente que o arquiteto deveria ocupar-se exclusivamente da atividade projetual enquanto que 0 engenheiro se encarregava da construção. Para ele, a função do arquiteto estava ligada a uma atividade nobre e artística e, portanto, estaria acima da construção, que seria uma mera atividade técnica.

Esta situação começaria a mudar lenta, porém efetivamente com a atuação do arquiteto paulista Rino Levi. Em seu projeto para o Cine UfaPalace em 1936, ele assumiria apenas a parte da elaboração dos desenhos e da fiscalização da obra, abandonando a execução da construção propriamente dita. ${ }^{51}$ Assim, 0 arquiteto de formação italiana marcava 0 início de uma nova atuação profissional vista agora como atividade liberal autônoma.

Assim, este é o quadro em que se encontrava Zenon Lotufo, ao concluir o curso de Engenheiro-Arquiteto na Politécnica de São Paulo. Seus primeiros trabalhos como profissional recém-formado apresentavam as linhas da arquitetura produzida e, de modo geral, ainda bastante aceita naquela época.

\footnotetext{
${ }^{51}$ Ficher, Silvia. Os arquitetos da Poli: ensino e profissão em São Paulo. Edusp, São Paulo, 2005, pg. 244.
}

\section{6. - Primeiros trabalhos profissionais}

"O Art Déco foi o suporte formal para inúmeras tipologias arquitetônicas que se afirmavam a partir dos anos de $1930 "{ }^{52}$

Hugo Segawa nos mostra em Arquiteturas no Brasil 1900-1990, que embora as discussões acadêmicas estivessem já um pouco atualizadas com a arquitetura praticada pelas vanguardas na Europa, muitos arquitetos brasileiros, entre eles Lotufo, ainda eram "obrigados" a repetir as fórmulas conhecidas do gosto eclético ou até Art-decó.

Portanto, as primeiras realizações de Zenon Lotufo estavam adequadas a certa "arquitetura nacional corrente", em que experiências formais se disseminavam pelo Brasil, mostrando uma fase de transição estética e técnica que valorizaria o uso do cimento armado, como veremos a seguir.

\footnotetext{
${ }^{52}$ Segawa, Hugo. Arquiteturas no Brasil 1900-1990. Edusp, São Paulo, 1999, pg.
} 
Paço Municipal de Taquaritinga (Taquaritinga/SP, 1936 - Não Construído) Projeto: Zenon Lotufo / Afonso lervolino (Concurso público - $1^{0}$. lugar) Fonte: Revista Grêmio Politécnico.

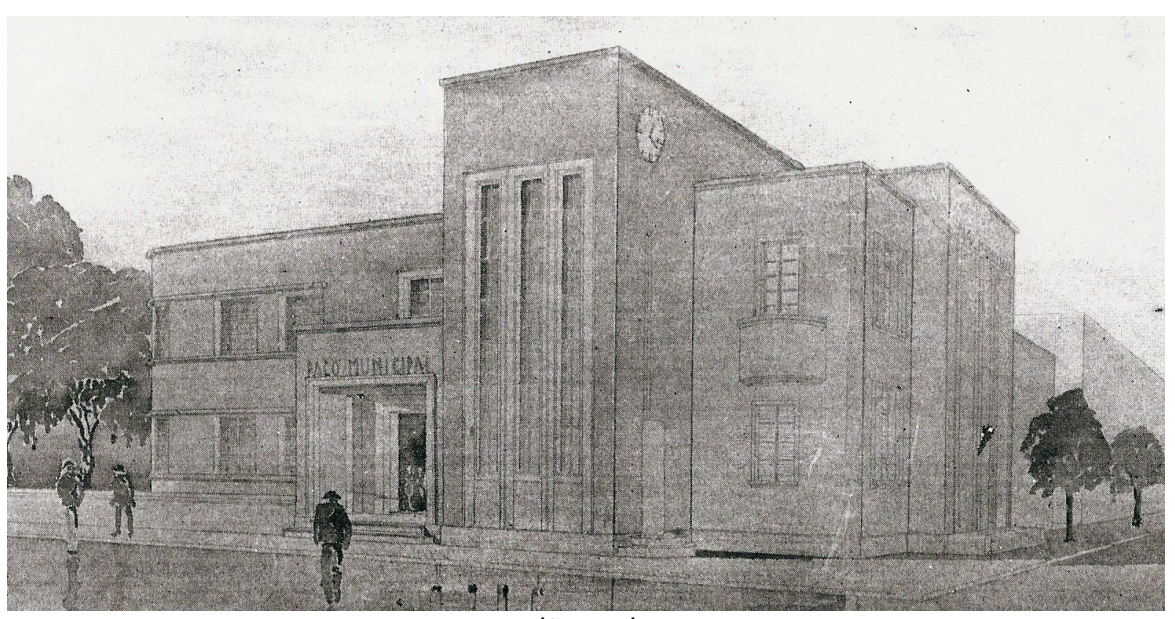

(fig. 18)

Zenon Lotufo acabara de se formar como engenheiro-arquiteto, e contou com a parceria de seu ex-colega de Escola Politécnica, Affonso lervolino, para vencer este concurso público.

De certa forma, o estilo racionalista do edifício denunciava o processo de transição da arquitetura paulista para linhas mais ortogonais e modernas, com simplificação dos ornamentos e busca de uma composição mais limpa e pura.

Observando a perspectiva do projeto (aliás, a única imagem conseguida), notamos que a composição destacava um volume verticalmente estendido com altas e compridas janelas, enfatizando a caixa de escada para o segundo nível, entrecortando a caixa horizontal deitada próximo ao acesso do edifício.

Um volume lateral também se prolongava em relação ao alinhamento da rua, marcando um ingresso para a parte interna do prédio. 0 tratamento sóbrio das molduras nas janelas, balcões e platibanda ilustrava 0 abandono gradual de ornamentação excessiva nas fachadas, fato bastante característico deste período.

0 aspecto geral da composição no desenho assemelha-se muito a um padrão de arquitetura produzida, principalmente na década de 30 , de modo geral no Brasil, aplicada a alguns edifícios públicos como paços municipais e agências de correios. Como afirma Segawa:

"Nos anos de 1930, conceitos como funcionalidade, eficiência e economia na arquitetura - termos próprios de soluções racionalistas tiveram firme aplicação em obras públicas". ${ }^{53}$

\footnotetext{
${ }^{53}$ Segawa, Hugo. Arquiteturas no Brasil 1900-1990. Edusp, São Paulo, 1999, pg. 66.
} 
Mercado M unicipal de Sorocaba (Sorocaba/ SP, 1937-38)

Fontes: Acrópole n.03, julho 38, p-36-37.

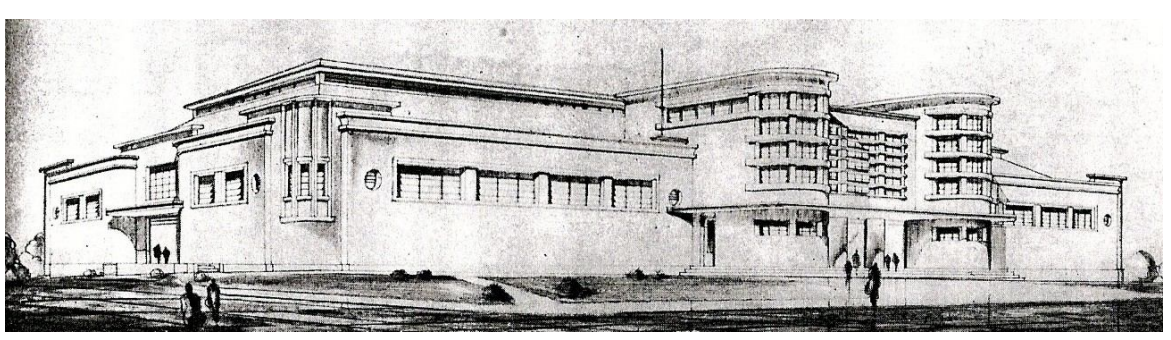

(fig. 19)

No início do ano de 1937, a Prefeitura M unicipal de Sorocaba abriu um concurso público para a construção de um novo prédio para o Mercado Municipal (área construída de $2.080 \mathrm{~m} 2$ ) que pudesse eventualmente receber exposições de produtores industriais. Neste concurso, novamente vencido por Zenon Lotufo e Afonso lervolino, os arquitetos procuraram dar ao edifício todas as comodidades desejadas, além de atender as recomendações de higiene necessárias ao bom funcionamento do Mercado: entradas amplas, perfeito escoamento das águas e instalações sanitárias. Internamente, foram localizados os "boxes" para laticínios, secos e molhados, açougues para carnes e peixes, acompanhando as paredes perimetrais e na área central as bancas para verduras, frutas e aves com passagens amplas entre si.

A clareza na distribuição das funções do edifício, bem como na circulação (entradas e saídas, corredores, fluxo de mercadorias e usuários) começaria a despontar como característica marcante do trabalho de Zenon.

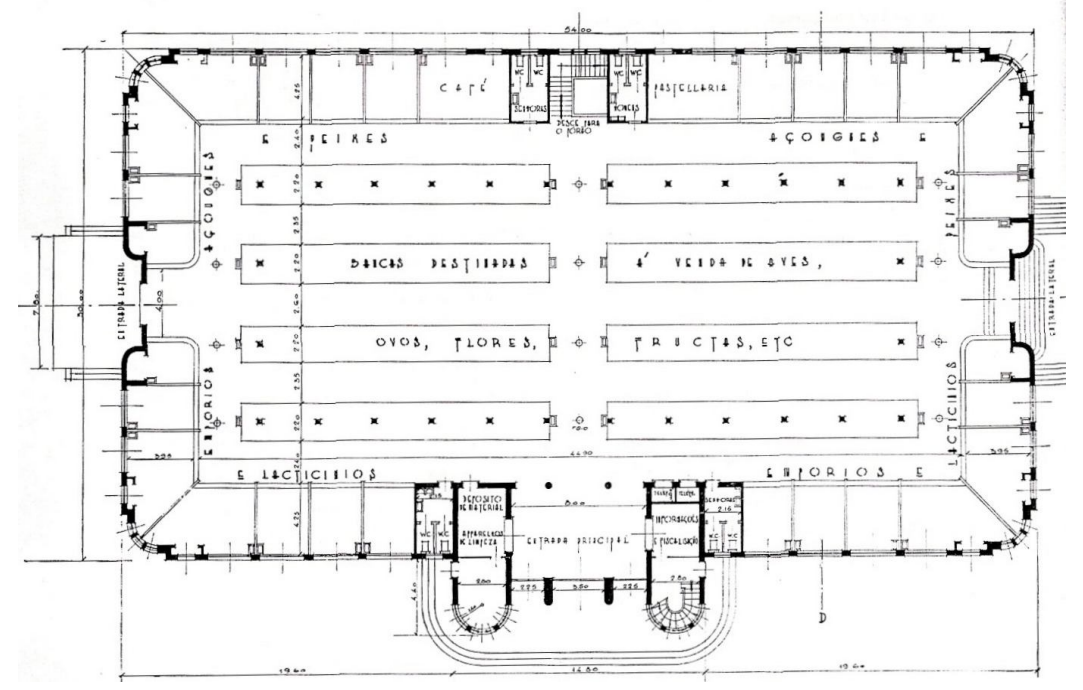

Planta baixa (fig. 20)

Outro fator que destacamos é a simetria dos eixos e da fachada na composição do edifício, influência da formação clássica dos arquitetos, ambos formados pela Politécnica de São Paulo.

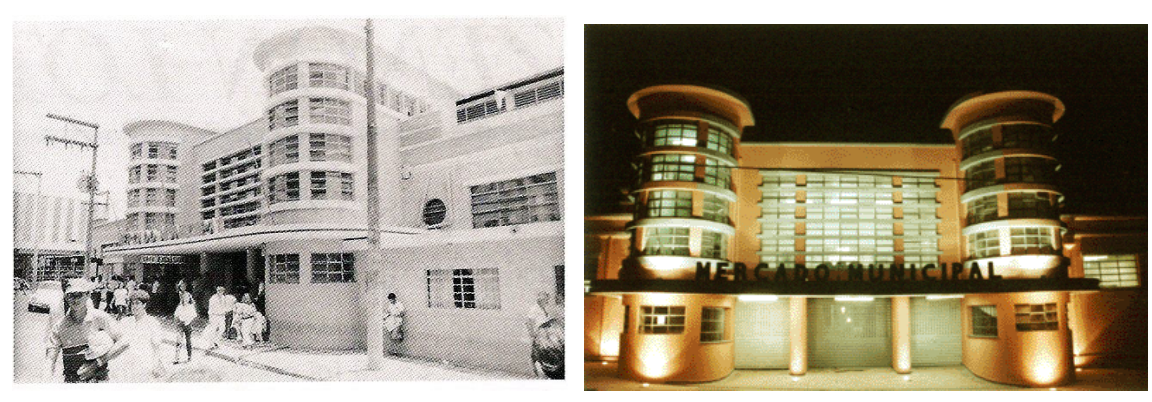

Figs. 21-22: M ercado de Sorocaba. Fonte: AU 76 e www.sorocaba.sp.gov.br. 


\section{7.- Início das atividades didáticas}

Zenon Lotufo foi assistente do professor Anhaia M ello na cadeira n.18

(Estética. Composição Geral e Urbanismo I e II) em 1938 (e depois, novamente em 1947), fato que daria início à suas atividades como professor acadêmico.

Interessante comparar a semelhança do programa da disciplina ministrada por Anhaia M ello, com o método Beaux-arts e a estrutura dos cursos de Guadet e Durand, onde primeiro se analisava as partes e os elementos do edifício, e depois as tipologias principais de edifícios.

Assim, destacamos do programa de curso naquela oportunidade (38) que se estruturava da seguinte forma:

\section{Elementos de composição (3‥ Ano)}

- Elementos de apoio (colunas, pilares, ordens, aberturas, portas, janelas, arcadas, frontões, galerias, colunatas, etc).

- Elementos apoiados (coberturas, tetos, abobadas, pavimentos, etc).

- Seções dos edifícios (ingressos, pórticos, escadas, claustros, gradis, etc)

\section{Edifícios (4‥ e 50. Anos)}

- Associação lógica das diferentes seções de acordo com 0 programa.
- Dados relativos à situação, orientação, clima e materiais.

- Distribuição e equilíbrio das massas.

- Edifícios particulares (casas operárias e burguesas, apartamentos)

- Edifícios públicos (hotéis, escolas, bibliotecas, penitenciárias, hospitais, bancos, lojas, mercados, restaurantes, fábricas, estações, teatros, etc).

\section{Estética (4‥ Ano)}

- Estética Geral: Definições. Beleza natural e artística. A filosofia da arte.

- Teoria estética. Hedonismo, sentimentalismo, intelectualismo, misticismo.

- As Belas-Artes. Artes plásticas e acústicas. 0 lugar do belo e da arte na cultura humana.

- Estética da Arquitetura. 0 útil e o belo. Os estilos. Sistemas fundamentais. Caráter profissional do arquiteto.

- As formas arquitetônicas. Formas de conveniência, estrutura e expressão.

- Vocabulário ornamental. Leis gerais do ornato.

- Teoria da arquitetura. Histórico da arquitetura na Antiguidade, Idade Média, Renascimento, Época moderna e contemporânea. Exame e crítica das principais teorias. 


\section{Urbanismo (50. Ano)}

- Sociologia: ciência, arte e organização social.

- Origem da vida urbana. Psicologia e sociologia.Tipos e estruturas de cidades: morfologia e ecologia.Crescimento e expansão urbana, mobilidade e metabolismo. Cidade e campo.

Desenvolvimento rural planejado. História das cidades - da préhistória a época moderna e contemporânea.

- A cidade, fenômeno geográfico e social; o município, unidade funcional. Administração pública municipal, opinião pública, finanças e orçamentos, contabilidade municipal.

- Avaliação de imóveis urbanos, economia urbana, propriedade.

- Legislação do urbanismo moderno. Zoneamento. Métodos europeus e americanos de planejamento.

- Organização de um Plano de Desenvolvimento. Elementos básicos de MasterPlan. Inquérito preliminar ou reconhecimento. Requisitos e finalidades.

- Planos Regionais. Estudo das relações de massa. Distribuição das populações: a habitação e a indústria. Salubridade das cidades.

- Elementos físicos de um Plano. Sistema viário. Espaços abertos. Zoneamento. Desenvolvimento local. Arquitetura e estética urbana
- A cidade-jardim. Exemplos atuais. Dinâmica do Plano. Circulação e trânsito. Serviços públicos e infra-estrutura urbana. ${ }^{54}$

Segundo depoimento de ex-alunos, como vimos anteriormente, Anhaia Mello era considerado um extraordinário professor graças à sua extrema capacidade didática e conhecimento teórico vasto. Suas aulas cativavam os alunos, pela visão técnica que tinha do planejamento aliada à perspectiva humanística que impregnava aos assuntos.

Organizava suas aulas sempre em fichas de papel-cartão separadas por temas onde agrupava: resumos feitos a mão, croquis e reproduções de interesse da matéria. Possuía uma excepcional capacidade de memória utilizando-a com desenvoltura à medida que organizava seu quadro negro.

Numa dessas reproduções (fig. 6) referiu-se à Teoria da Arquitetura como conjunto de conhecimentos técnicos e artísticos necessários à exteriorização da visão estética. Agrupando os Elementos de Ordem em: 1. M aterial (estáveis e impostos de fora) como solo, materiais e clima; 2. Sócio-Econômica (instáveis e impostos de fora) como programa, custos e legislações; e 3. Artístico (estáveis e pessoais) como partido, composição, proporção, escala, correções óticas, realce e possibilidades técnicas de

\footnotetext{
${ }^{54}$ Trecho extraído do Programa da Cadeira no. 18 "Composição Arquitetônica e Urbanismo" de 1938, do curso de Engenheiro-Arquiteto da Escola Politécnica da Universidade de São Paulo.
} 
execução. Por fim, destaca-se uma frase que diz: "só do justo equilíbrio dos fatores técnicos e artísticos nasce a obra de arte verdadeira"..$^{55}$ Zenon compartilhava esta mesma visão sobre a disciplina arquitetônica.

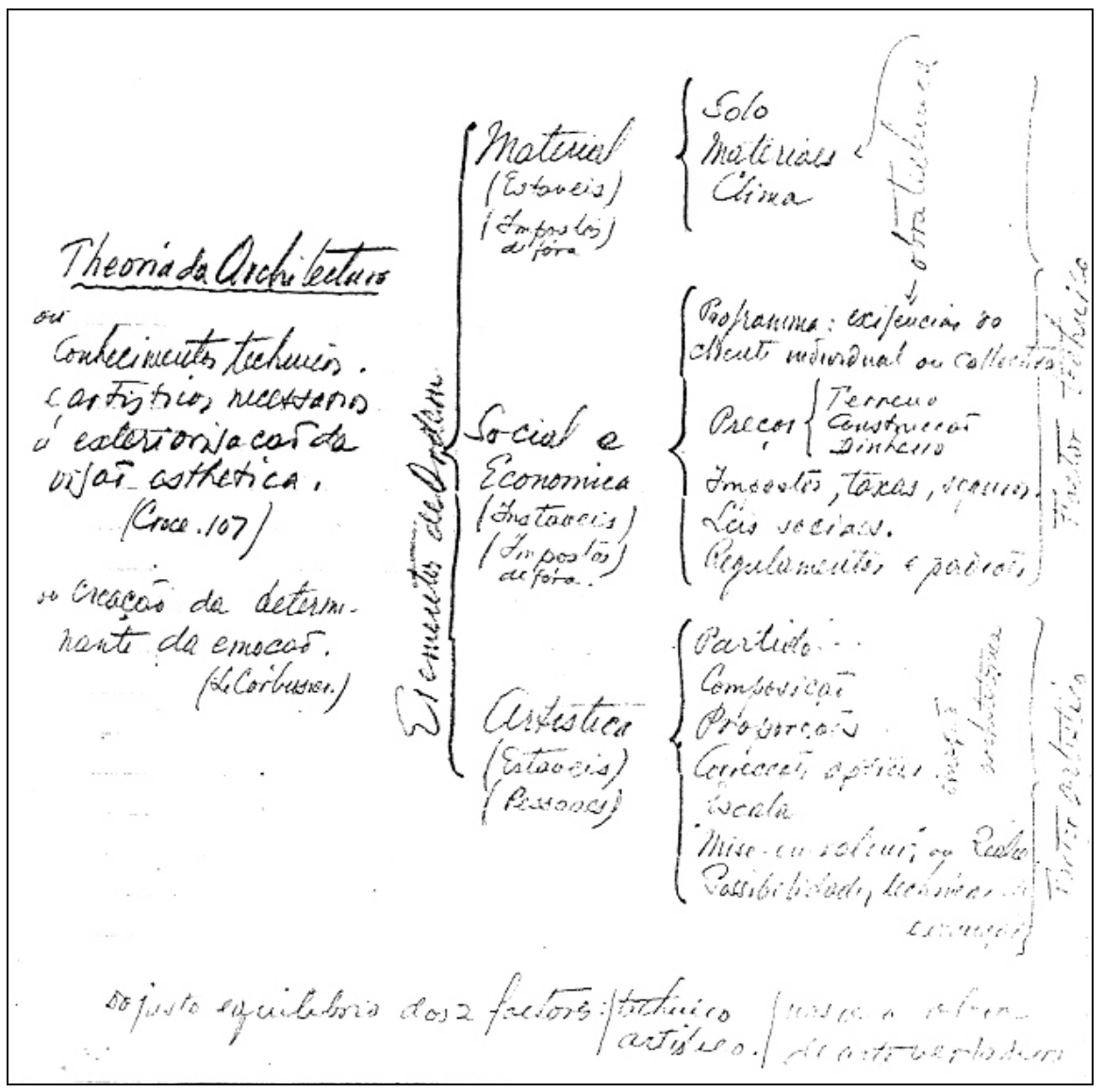

Fig. 23: Anotação de aula de Anhaia M ello. Fonte:(idem nota abaixo).

${ }^{55}$ Documentos sobre o urbanista LII.R. Anhaia Mello, FAUUSP, São Paulo, 1986, pg. 18.

\section{8-Experiência na administração pública de Santos (39-45)}

0 curso de engenheiro-arquiteto na Politécnica oferecia uma ampla formação em diversas áreas e assuntos como as disciplinas de Urbanismo, Contabilidade, Economia e Saneamento Urbano.

Constatamos pela abrangência urbanística e pelo conteúdo do programa curricular aliada à rigorosa formação técnica dos alunos na Politécnica, a possibilidade dos mesmos em atuarem em diversas áreas de trabalho e cargos públicos, como o cargo de Chefe da Divisão de Obras Particulares da Prefeitura de Santos que Zenon Lotufo exerceu de 1939 até meados de 1945 (período que curiosamente coincide com a 2 a. Guerra M undial). Além disso, Zenon Lotufo já tinha experiência em cargos públicos, pois havia trabalhado antes como desenhista (35-36) e depois de formado como arquiteto contratado na Secretaria de Viação e Obras Públicas da Prefeitura de São Paulo (37-38).

Assim, aceitou o convite de Roberto Simonsen (que havia conhecido Zenon no jornal Estado de São Paulo, onde trabalhou na época de estudante da Politécnica) para atuar na diretoria de Obras Públicas de Santos, vindo a realizar importantes obras como o Código de Obras de Santos e São Vicente, os Postos de Salvamento da Orla M arítima e o Orquidário M unicipal, entre outros. 
Aquário Municipal de Santos (Santos/ SP, 1943-45)

Construção: Soc. Const. e de Imóveis Silvio Passarelli.

Fonte: Acrópole, jan 46.

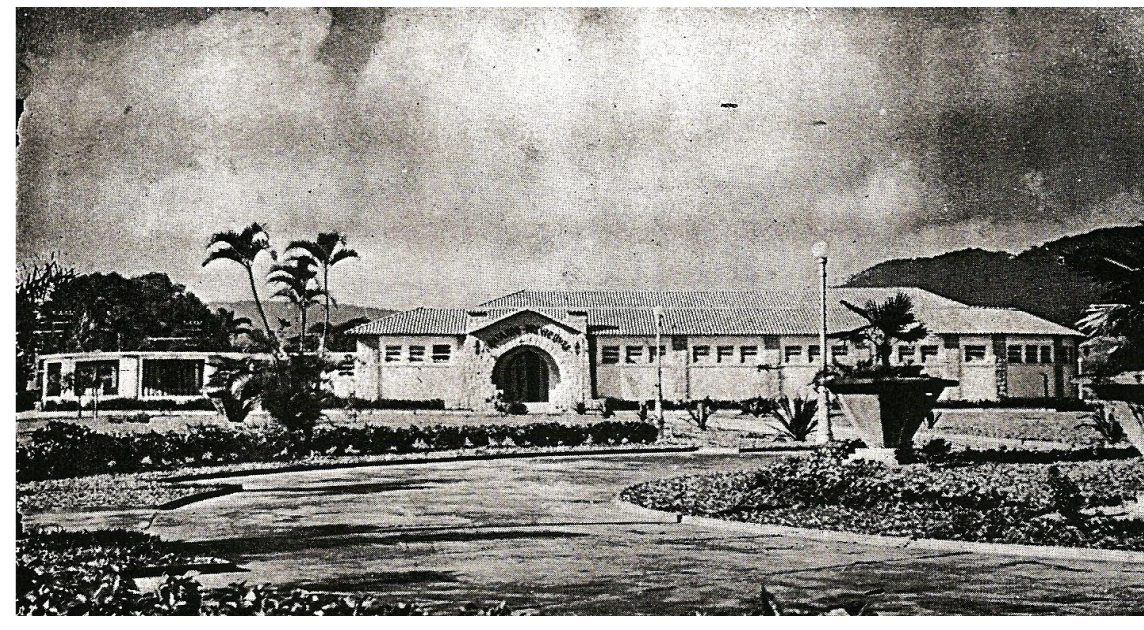

Fig:24

Este edifício seguia o chamado estilo neocolonial caracterizado por alguns elementos de certa herança construtiva portuguesa, como neste caso, o

telhado cerâmico.

Situado nos jardins da praia bem próximo da entrada do porto na Avenida Bartolomeu de Gusmão (Ponta da Praia) apresenta uma separação funcional de espaço público e serviços bastante claros e distintos internamente. Os espaços reservados ao uso público estavam definidos por um amplo corredor de 3 metros de largura, ladeados por janelas. Um grande tanque de 13 metros de diâmetro rodeado por uma circulação avarandada com peitoril de 1,5 metros situa-se na extremidade esquerda do prédio (como se vê na planta).

Inaugurado em 1945, com a presença do presidente Getúlio Vargas, 0 Aquário é um importante marco arquitetônico e turístico para a baixada santista. Recentemente em 2004, sofreu uma reforma e ampliação em sua estrutura, fato que descaracterizou intensamente sua fachada frontal e volumetria.

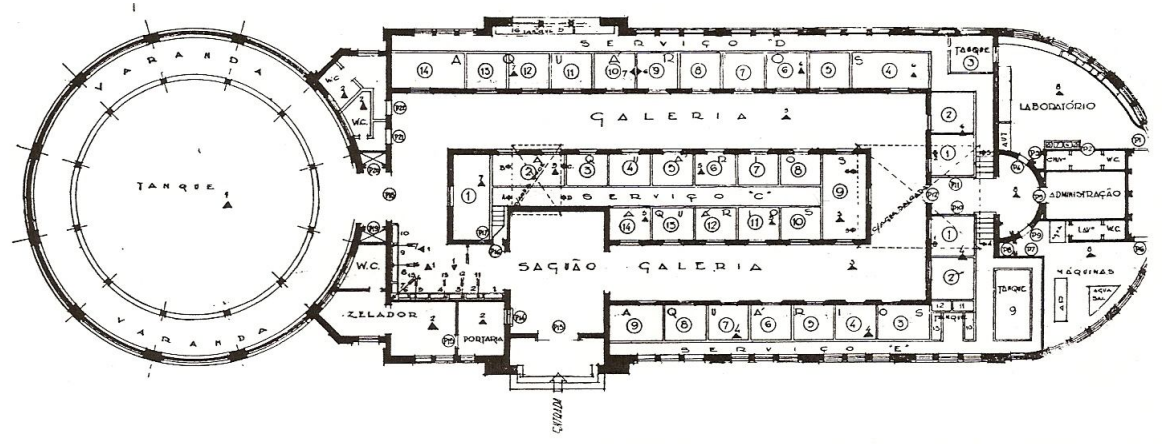

Planta baixa (fig. 25)

Novamente, ao analisar rapidamente a planta, observamos a clareza na distribuição das funções do edifício, fato que caracteriza uma preocupação constante na obra de Zenon Lotufo. 


\subsection{Prefeito nomeado de Campos do Jordão (46)}

Encontramos pouco material sobre este período de atividades na carreira de Zenon Lotufo quando foi prefeito nomeado em 46.

No entanto, uma publicação da década de 60 relatou um importante trabalho realizado nesta época, mas que fora fruto de serviço anterior prestado pelo arquiteto, ou melhor, prefeito, e que reproduzimos alguns trechos.

Em 1960, o então Centro de Pesquisas e Estudos Urbanísticos (CPEU) da Faculdade de Arquitetura e Urbanismo publicaram o Relatório e Pranchas do Planejamento Territorial referente ao Plano Diretor da Estância de Campos do Jordão ${ }^{56}$. Naquela ocasião, eram autoridades públicas, os seguintes senhores: Prof. Dr. Carlos Alberto de Carvalho Pinto (Governador do Estado), Brig. J. V. de Faria Lima (Secretário da Viação e Obras Públicas), Prof. Dr. Antônio de Barros Ulhôa Cintra (Reitor da Universidade de São Paulo), Prof. Dr. Luiz Ignácio Romeiro de Anhaia Mello (Diretor FAUUSP), Dr. José Antonio Padovan (Prefeito da Estância) e o Arquiteto Zenon Lotufo (Diretor Geral do Planejamento da Estância). Na Introdução, apontavam-se as características peculiares da situação geográfica do município, acoplado à Serra da Mantiqueira, contendo paisagens pitorescas onde se destacava a presença de araucárias.

${ }^{56}$ Centro de Pesquisa e Estudos Urbanísticos (CEPEU). Plano Diretor de Campos do Jordão: relatório e pranchas de planejamento territorial. FAUUSP, 1960.
As médias de temperatura anual em Campos do Jordão (altitude 1630m) chegavam aos $13^{\circ} \mathrm{Co}$ que lhe valeu na época o apelido de "paraíso de clima tropical", recebendo por isso clinica de recuperação de problemas pulmonares e outras sanatoriais, além de sua altitude de $1630 \mathrm{~m}$.

No histórico consta que desde sua fundação, a cidade sanatorial voltarase para o turismo nacional e internacional, merecendo atenção dos governos estaduais. Em 35, o governador Salles de Oliveira nomeou uma comissão presidida por Prestes Maia para elaborar estudos de urbanização.

A partir de 39, houve um surto turístico na estância com obras de grande porte como hotéis, estradas e melhorias urbanas, mas de uma maneira isolada e sem visão de conjunto.

Em 46, o arquiteto Zenon Lotufo foi nomeado Prefeito da Estância, num período de transição de ditadura militar para reconstitucionalização do país, ou seja, época de grande atividade política, conseguindo mesmo em poucos meses, encaminhar medidas para o planejamento municipal. E mais tarde, em 52, colaborou novamente nos estudos preliminares para 0 Plano Diretor da Estância que acabaram não se realizando por falta de financiamento. Em 58, o governador Jânio Quadros assinou convênios para o planejamento das estâncias paulistas. Zenon Lotufo coordenou 0 trabalho como diretor geral de planejamento na Estância de Campos do Jordão. 
A Comissão Técnica iniciou seus trabalhos com uma série de reuniões públicas para exposição e debates de assuntos referentes ao Plano. A primeira fase dos trabalhos, junto com os dados dos arquitetos e 0 conhecimento da região através de levantamento aerofotogramétrico resultou no Plano Piloto, aprovado pela Câmara em 59.

A análise geral (diagnóstico) revelou a precariedade de infra-estrutura básica como pavimentação, rede de esgoto, galeria de águas pluviais, coleta de lixo. No entanto, o abastecimento de água, luz, telefone, e iluminação pública apresentaram-se como eficientes em $80 \%$ dos casos. Um levantamento geral dos equipamentos escolares da época apontou 35 salas de aula, sendo 31 estaduais e 4 particulares, e um total de 1850 alunos sendo 50 professores para o ensino primário de 7 a 14 anos, além de mais 6 escolas rurais. Um número de alunos baixo pela capacidade disponível segundo análise do plano. Os equipamentos de saúde resumiam-se 13 sanatórios para tuberculose e 5 abrigos ou instituições assistenciais, e nenhum hospital geral.

Quanto aos equipamentos esportivos, contavam-se 7 clubes recreativos e culturais, 3 bibliotecas e um único cinema.Edifícios para cultos religiosos: 8 igrejas católicas (8,5 mil fiéis) , 3 protestantes, 3 espíritas. Em relação à estrutura turística: 8 hotéis (800 leitos) e 4 colônias de férias. Os principais atrativos geográficos eram: Pico de Itapeva, Pico do Imbiri,
Morro do Elefante, Palácio do governo, Parque da Ferradura, Pedra do Baú, Horto Florestal, e as fontes de água mineral.

Destacava-se também a grande presença de loteamentos clandestinos sendo 56 no total, onde os tipos de habitação: precárias (56\%), popular (20\%), média (10\%), luxo $(2,6 \%)$ e turismo (10\%)

E as áreas verdes correspondiam a $21 \%$ da área urbana, sendo a maioria de matas naturais existentes, porém não possuindo espaços de lazer específicos para a população como praças e parques.

\section{Fundamentos e composição do Plano}

Segundo o diagnóstico do Plano, a principal função do município era de estação de tratamento de moléstias pulmonares e estância de repouso. Mas, deveria se caracterizar efetivamente como centro turístico nacional e internacional polarizado por Rio de Janeiro, São Paulo e Belo Horizonte. Assim, o Plano Diretor determinou a valorização por zoneamento de extensa faixa territorial ao longo do Rio Capivari, permitindo nela apenas a construção de edifícios multifamiliares (sem restrição de número de pavimentos) respeitados apenas coeficientes de uso e ocupação do solo. Seguindo esta mesma faixa, previa-se a instalação de zona comercial linear, compatível com a população flutuante, com incentivos para 0 artesanato local e a fruticultura. 
Além disso, o Plano Diretor visava a proteção da zona rural tanto para a produção agrícola quanto para o turismo, ou seja, preservação das belezas naturais e meio ambiente, proibindo queima e derrubada de matas ciliares, ou seja, faixa de 15 metros de largura das margens dos rios e cursos d'agua, além de obras que alterassem os acidentes naturais. Este fato mostra certa visão profética e preocupação antecipada de Zenon Lotufo frente à proteção dos recursos naturais como bosques, matas e reservas florestais.

Outras iniciativas seriam o incentivo à criação de clubes agrícolas (conscientizar os jovens dos problemas do campo); à piscicultura (construção de viveiros de peixes abertos à visitação e comercialização), à fruticultura (estação experimental e de fomento de frutas para a região), à floricultura (programa de incremento ao cultivo e comercio de flores da região), aos acampamentos (abrigos pra escotismo e atividades similares com crianças e jovens) e às unidades turísticas (loteamentos com lotes mínimos de mil $m 2$ constituídos por um hotel ou atração turística que justificaria esta condição, e a gleba não poderia ser inferior a 12 mil m2). O objetivo principal para a zona urbana era consolidação de um sistema viário eficaz, aliado à setorização do uso da terra urbana e à criação de espaços verdes.
Assim, o sistema viário se daria segundo uma hierarquia das vias projetadas no esquema dos seguintes cortes transversais: vias-parque, vias-principais e vias-marginais dos rios e ribeirões (ver figura abaixo).

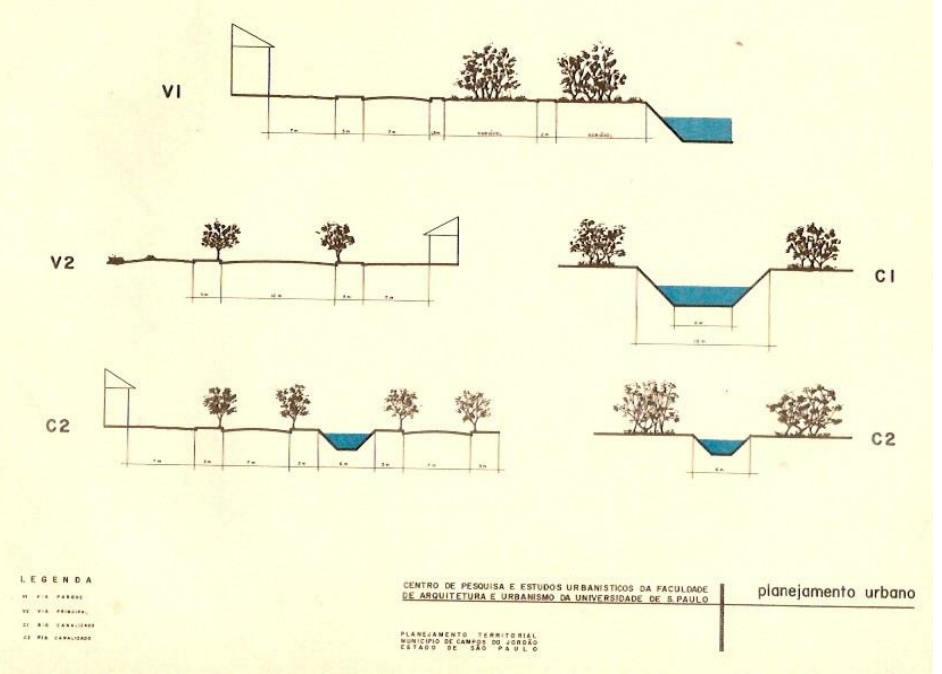

Fig. 26:Tipos de sistema viário propostos. Fonte: CEPEU

Em relação ao uso da terra, estes se dividiram em: áreas residências (subdividas segundo a densidade, 50, 140, 200 ou 1000 pessoas por hectare); áreas comerciais (3 tipos: centro comercial de vizinhança, linear ao longo do rio Capivari, ou seja, térreo dos edifícios, e centros de bairros); áreas industriais (pequenas industrias tipo manufatura em pequena área) e área sanatorial (ou parque sanatorial onde estariam os sanatórios, podendo ser referência no tratamento e pesquisa das moléstias). 
0 espaços verdes seriam basicamente de 3 tipos: reservas florestais (20\% da zona urbana, remanescentes de floresta tropical que predominavam na região), recreio ativo (praças de esportes projetadas no vale do Capivari) e recreio contemplativo (projetos e tratamento paisagístico, arborização, represas de rios para formação de lagos nos vales do Capivari e Abernéssia).

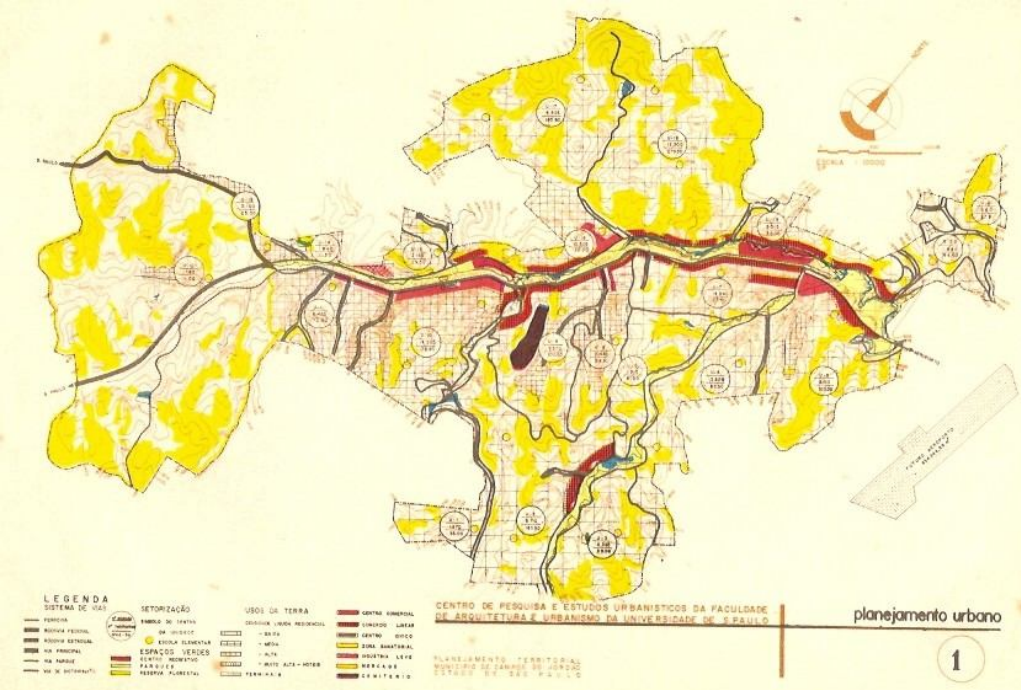

Fig. 27: Zoneamento proposto. Fonte: CEPEU.

E finalmente, quanto à setorização da estância, previa-se a subdivisão da cidade em 20 setores ou unidades de vizinhança sendo prevista a população e área de cada setor, bem como o dimensionamento futuro dos equipamentos (escolas, praças, creches, etc) e infra-estrutura (água, luz, esgoto).

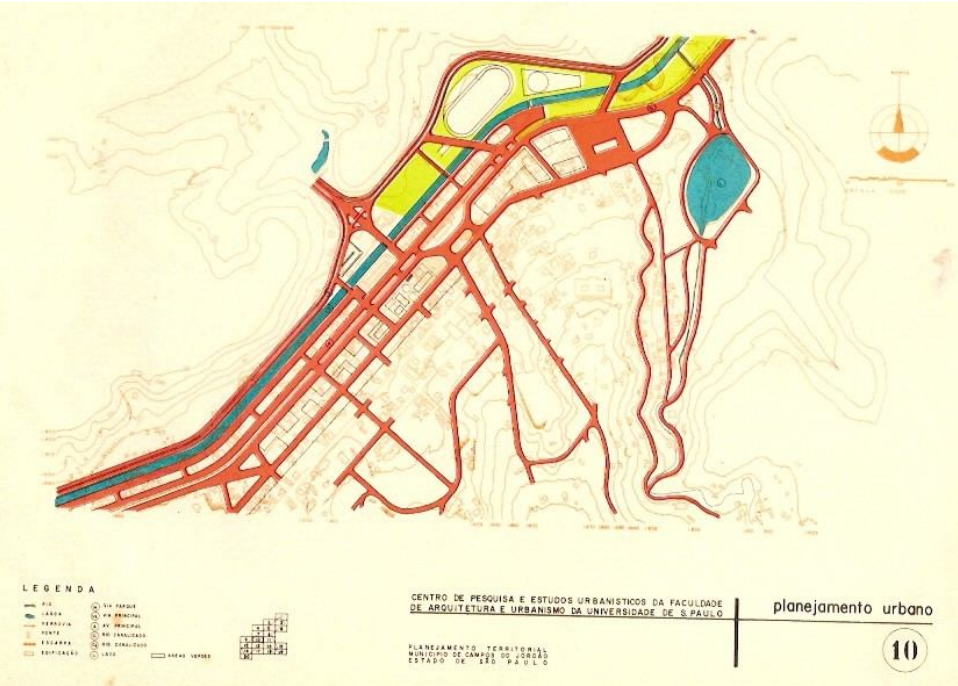

Fig. 28: Detalhe da integração sistema viário e áreas de lazer. Fonte: CEPEU.

\section{Conclusão}

Portanto, esta primeira fase (31-46) da atuação profissional de Zenon Lotufo esteve pautada principalmente pela sua formação acadêmica no curso de Engenheiro-Arquiteto na Escola Politécnica em São Paulo, sua relação próxima com Anhaia Mello, sendo seu assistente por duas ocasiões (38 e 47), a parceria e os primeiros trabalhos como recémformados com Afonso lervolino, e por fim, as experiências na 
administração pública em duas oportunidades, na diretoria de obras de Santos e a prefeitura de Campos do Jordão.

Este itinerário contribuiu de maneira decisiva para consolidar a formação inicial do conjunto de valores do jovem arquiteto em relação à sua postura profissional e acadêmica, passando a partir de então a realizar com mais ênfase os preceitos da arquitetura moderna, porém perpetuando os valores clássicos adquiridos na sua formação.

Em 1943, Zenon Lotufo era um dos sócio-fundadores do departamento paulista do Instituto dos Arquitetos do Brasil (IAB-SP) juntamente com: Eduardo Kneese de M ello (primeiro presidente), İcaro de Castro M ello, Rino Levi, Oswaldo Bratke, Oswaldo Corrêa Gonçalves, Ribeiro de Moraes, Miguel Forte, J oão Cacciola, Hélio Duarte, Abelardo de Souza, Francisco Beck, Hélio Uchoa, Gregori Warchavchik, Francisco Kosuta, Roberto Cerqueira César, entre outros. ${ }^{57}$

Tal fato possibilitou uma maior aproximação com o grupo carioca e a introdução definitiva aos princípios da arquitetura moderna,

principalmente com Abelardo de Souza e Hélio Duarte, com quem Zenon Lotufo realizou parceria a partir de 46, montando escritório em São Paulo à Rua Barão de Itapetininga, como mostraremos no capítulo seguinte.

\footnotetext{
${ }^{57}$ Como mostra a placa de Fundação, localizada no térreo na Sede do Instituto.
} 
Capítulo 2 - Escola carioca e afirmação moderna (46-58)

\section{1 - Contextos}

A cidade de São Paulo no pós-2a Guerra M undial (a partir de 45) apresentou crescente e veloz processo de industrialização resultando em alta taxa de urbanização.

Aliado a este fato, uma maior aceitação e difusão da linguagem moderna arquitetônica passou a transformar a paisagem urbana das principais capitais nacionais. 0 edifício do M inistério de Educação e Saúde Pública (M ESP) no Rio de Janeiro é considerado por vários autores como divisor de águas do modernismo brasileiro.

Este projeto emblemático realizado em 1936 teve a participação direta de Le Corbusier, que a convite de Gustavo Capanema, então ministro da Educação, e Lúcio Costa, chefe da equipe de arquitetos, contando também com a presença do então jovem arquiteto Oscar Niemeyer. Neste edifício são experimentados pela primeira vez os 5 pontos da nova arquitetura propostos por Corbusier: pilotis, teto-jardim, planta-livre, janelas em tira horizontal e estrutura independente. Porém, o grupo de arquitetos brasileiros deu "personalidade própria à sintaxe 
corbusiana" ${ }^{58}$ esboçando alguns elementos plásticos que se tornariam característicos da nova linguagem.

Após o episódio do MESP, Lúcio Costa convidou Oscar Niemeyer para projetar o Pavilhão da Feira M undial de Nova York em 39, fato que consagraria não apenas o arquiteto, mas a nova plasticidade da arquitetura brasileira no âmbito internacional.

Logo em seguida, Juscelino Kubitschek (então prefeito de Belo Horizonte) contrataria Niemeyer para seu grandioso conjunto da Pampulha, projeto em que 0 arquiteto expressou sua capacidade criativa sobrepujando os padrões racionalistas a generosas curvas. Eque contribui de forma decisiva para a ascensão de consolidação como gênio da nova arquitetura nacional.

Outro fato importante que ocorreu nesta época (1943) foi a exposição e a publicação do livro Brazil Builds no M useu de Arte Moderna de Nova York, organizada por Philip Goodwin que percorreu o país registrando nossa arquitetura antiga e confrontando-a com a moderna que estava sendo produzida, principalmente pelo grupo carioca (dos 40 projetos modernos mostrados, 30 eram de autoria de arquitetos formados pela Escola Nacional de Belas Artes do Rio de Janeiro). ${ }^{59}$ Isto caracterizou ainda mais a então capital federal do país como centro difusor, não apenas do novo

\footnotetext{
${ }^{58}$ Segawa, H. Arquiteturas no Brasil 1900-1990. Edusp, São Paulo, 1999, pg. 91.

${ }^{59}$ Lemos, C. Arquitetura brasileira. M elhoramentos, São Paulo, 1979, pg. 143.
}

estilo ou corrente, mas de um novo modo brasileiro de se construir arquitetura.

"A partir da década de 40, arquitetos do Rio de Janeiro são chamados a trabalhar em São Paulo, e os arquitetos paulistas, assim como em outros estados, deixaram transparecer em suas obras a influência marcante da arquitetura carioca". ${ }^{60}$

\section{2 - Parceria com os cariocas: Abelardo de Souza e Hélio Duarte (46-49)}

Após a experiência na administração pública em Santos (39-45) e depois em Campos do Jordão (46), Lotufo retornaria a cidade de São Paulo fixando seu endereço comercial a Rua Barão de Itapetininga, juntamente com Abelardo de Souza e Hélio Duarte.

A aproximação entre os arquitetos cariocas teve início principalmente com a movimentação política em torno do Instituto dos Arquitetos do Brasil (IAB) e a fundação do departamento em São Paulo no início da década de 40.

No grupo de arquitetos sócio-fundadores constavam, além deles, nomes como: Eduardo Kneese de M ello (primeiro presidente), Rino Levi, Oswaldo Bratke, Ícaro de Castro M ello, Oswaldo Corrêa Gonçalves, Ribeiro de M oraes, Miguel Forte, João Cacciola, Francisco Beck, Hélio

${ }^{60}$ Constantino, R. A. - A obra de Abelardo de Souza. Mestrado FAUUSP, 2004, pg. 53. 
Uchoa, Gregori Warchavchik, Francisco Kosuta e Roberto Cerqueira César, dentre outros. ${ }^{61}$

Abelardo Riedy de Souza, carioca nascido em 1908, formou-se arquiteto pela Escola Nacional de Belas Artes no Rio de Janeiro em 1932. Pertence, portanto, a geração de arquitetos que mudou os rumos da arquitetura brasileira. Os anos de sua formação foram turbulentos, pois nessa época a ENBA passou por processo intenso de reforma curricular encabeçado pelo carioca Lúcio Costa.

“Víamos através das poucas revistas que nossos colegas Carlos Leão, Luiz Nunes e Affonso Reidy traziam que existia um franco-suíço chamado Charles E. Jeanneret, mais conhecido como Le Corbusier, que abria os olhos do mundo para uma nova maneira de viver" ${ }^{62}$

Por sua vez, o baiano Hélio Duarte (1906-1989) realizou algumas peregrinações, o que colaborou ainda mais para uma difusão da nova linguagem arquitetônica em outros cantos do pais como, por exemplo, Salvador onde foi professor até $1944 .{ }^{63}$ Formado pela Escola Nacional de Belas Artes do Rio de Janeiro em 1930 (antes da reforma de Lúcio Costa), Duarte trabalhou no Rio e em Salvador, antes de se fixar definitivamente em São Paulo na metade da década de 40, onde faria um importante

\footnotetext{
${ }^{61}$ Ferraz, A.R.F., M arcas do M oderno na Arquitetura de Bauru. Mestrado EESCUSP, 2003, pg. 65.

${ }^{62}$ SOUZA, Abelardo Riedy de. Arquitetura no Brasil: Depoimentos. Diadorim/ EDUSP, São Paulo, 1978.

${ }^{63}$ Segawa. H. Arquiteturas no Brasil 1900-1990. Edusp, São Paulo, 1998, pg. 142.
}

trabalho junto à coordenação do Convênio Escolar, a partir de 48, projetando com uma equipe de arquitetos, mais de cem escolas estaduais. Tal fato foi determinante para que a parceria com Zenon e Abelardo se encerrasse.

Assim, a influência da escola carioca começou a despontar na presença de linhas sinuosas e maior leveza plástica que se somaria ao racionalismo estrutural do engenheiro politécnico. 


\section{3 - Principais projetos realizados pela parceria}

Sede do Instituto de Arquitetos do Brasil (IAB) (São Paulo/SP, 1946-7 -

Projeto original não foi encontrado)

Projeto: Zenon Lotufo / Abelardo de Souza / Hélio Duarte
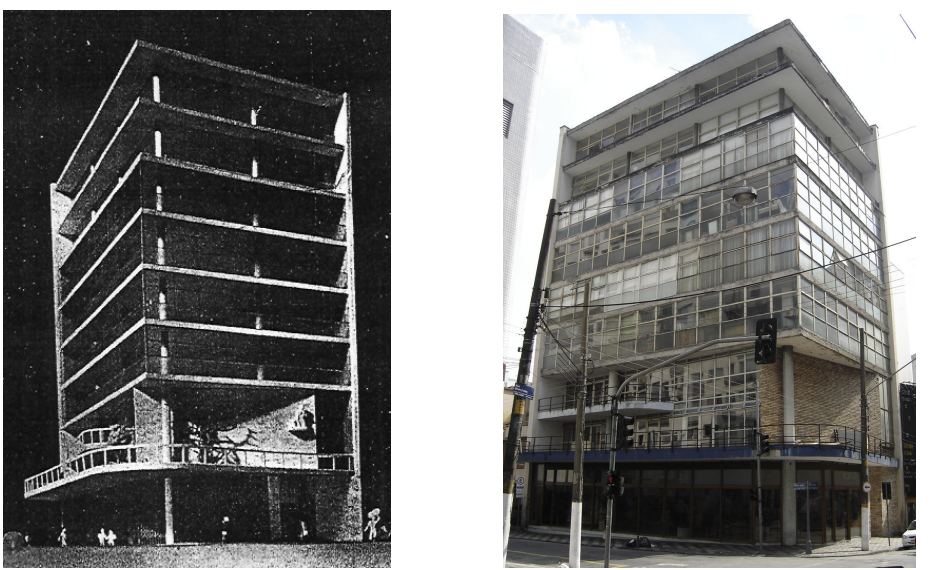

Figs. 29-30: Fotos maquete e recente. Fontes: Acrópole e EMF. ${ }^{64}$

Em 46, um concurso interno promovido entre os arquitetos escolheu os projetos de três equipes participantes para o edifício sede do departamento paulista do IAB. O júri composto por Firmino Saldanha, Oscar Niemeyer, Hélio Uchoa e Fernando Britto decidiu optar por um empate entre os trabalhos de Abelardo de Souza, Hélio Duarte e Zenon Lotufo; Jacob Ruchti, Miguel Forte e Galiano Cimpaglia, e Rino Levi e Roberto Cerqueira César. Importante marco da arquitetura moderna paulista, este edifício abrigou e ainda hoje mantêm os escritórios de

\footnotetext{
${ }^{64}$ Eduardo M odenese Filho.
}

alguns dos mais renomados arquitetos do Brasil como Vilanova Artigas, Paulo Mendes da Rocha, Fábio Penteado, Ciro Pirondi, entre outros. Infelizmente, não conseguimos localizar o projeto original apresentado pelos arquitetos: Zenon, Abelardo e Hélio. 0 projeto mostrado aqui foi desenvolvido por Rino Levi, Roberto Cerqueira César e Jacob Ruchti, Miguel Forte e Galiano Cimpaglia.

Programa: Subsolo: Auditório; Térreo: Hall Acesso / Exposições; $1^{0}$ pavimento e mezanino: Sede social; $\mathbf{2}^{\circ}$ ao $7^{\circ}$. pavimento: Escritórios.
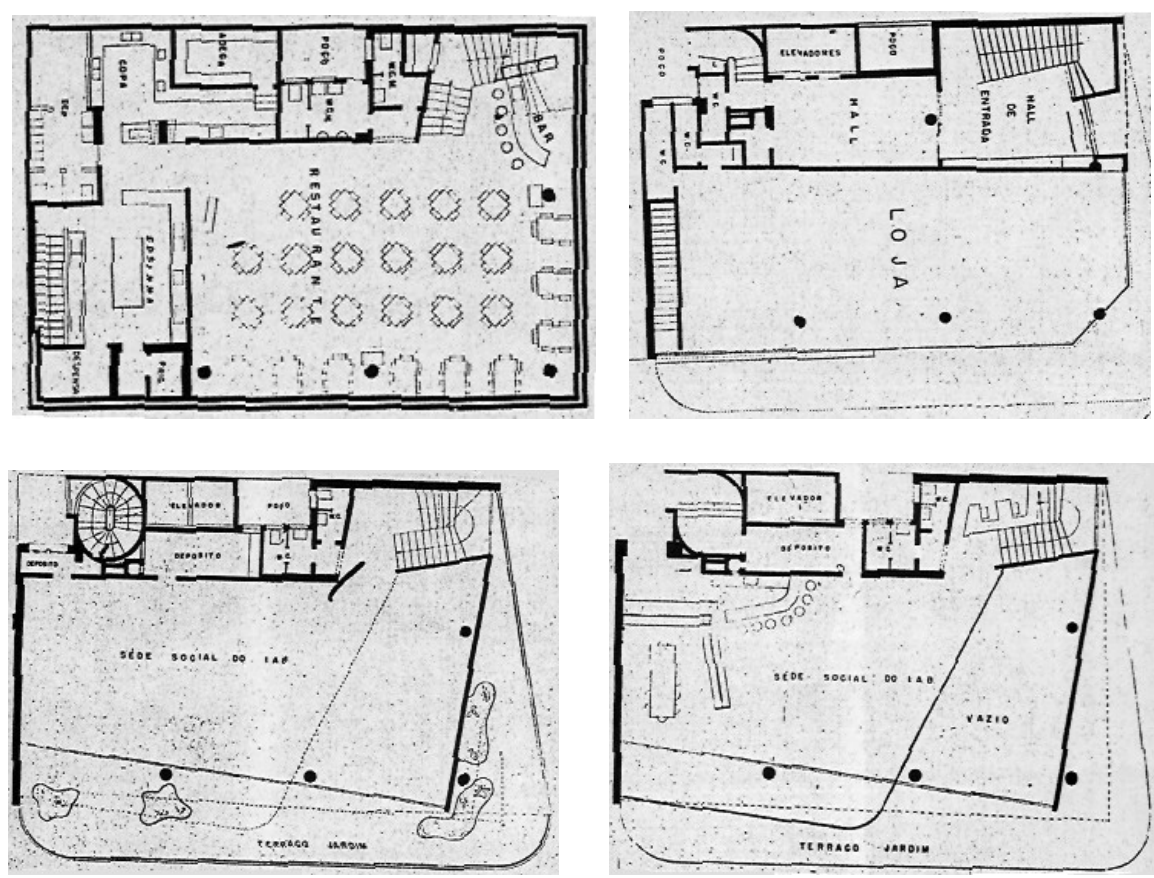

Figs. 31-34: Plantas - Subsolo (Restaurante)/ Térreo (Loja) / Terraço (Sede Social IAB) / Mezzanino (Sede Social IAB). 
Grêmio Recreativo de Ourinhos (Ourinhos/SP, 1946- Não construído) Projeto: Zenon Lotufo / Abelardo de Souza / Hélio Duarte Fonte: Acrópole, maio 46, p. 38-40.

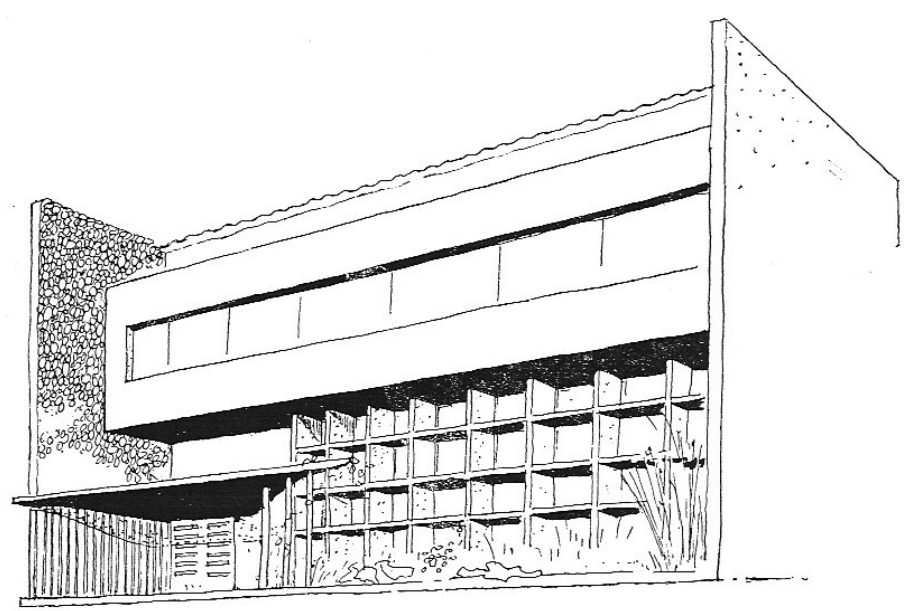

Fig. 35

Ocupando um lote de $18 \mathrm{~m}$ por $28 \mathrm{~m}$ e área aproximada de $1.500 \mathrm{~m} 2$, este projeto para a Sede social do Grêmio Recreativo de Ourinhos, município do interior do estado de São Paulo, marca o início da segunda fase da produção de Zenon Lotufo e a primeira publicação do então formado grupo com os arquitetos: Abelardo de Souza e Hélio Duarte. A presença constante de linhas curvas nas plantas revela a influência da escola carioca, uma vez que Abelardo e Hélio haviam se formado na Escola Nacional de Belas Artes do Rio de Janeiro.
Essa busca por fluidez espacial refletia-se nos contornos sensuais do território brasileiro em suas praias e montanhas e rebatia-se na arquitetura daquele momento, ávida por uma identidade própria e nacional. A composição volumétrica ilustrada (página anterior) pela perspectiva da fachada frontal mostra-nos a referência aos princípios modernos de Le Corbusier como, por exemplo, o uso da janela em tira horizontal que marcava o primeiro pavimento. A estrutura do edifício pautava-se pelo ritmo dos pilares cilíndricos organizados em modulação de 4,50m por 4,5m e $9 \mathrm{~m}$ entre eixos.

A circulação vertical do prédio estava definida por uma grande escada circular espiral com degraus de $2 \mathrm{~m}$ de largura situada nos fundos e um elevador.

Além disso, nota-se a presença de brises quadriculados para a proteção solar no térreo, outro elemento característico da linguagem moderna brasileira. M uros laterais nas divisas terminam por organizar a estrutura e o caráter do projeto além da marquise da entrada que sutilmente marcava o ingresso do edifício.

Programa: Térreo: Chapelaria/ Salão de jogos e estar/ Bar com cozinha e serviços/ Barbearia/ M anicure/ Sanitários; Mezanino: Balcão com estar e descanso/ sanitários/ terraços/ depósito; $\mathbf{1}^{\circ}$. Pavimento: Salão para baile com palco para orquestra/ Bar/ Copa e serviços; $\mathbf{2}^{\circ}$. Pavimento:

Biblioteca/ Diretoria/ Salas administração/ Terraço coberto/ Sanitários. 

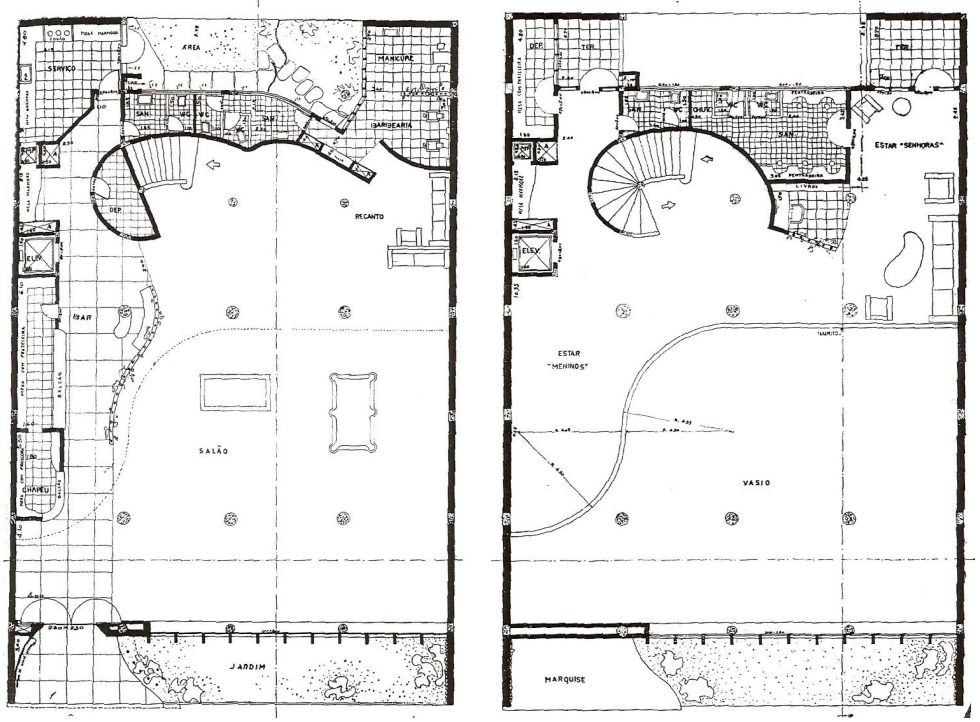

Figs. 36-37: Plantas do Térreo e Mezanino

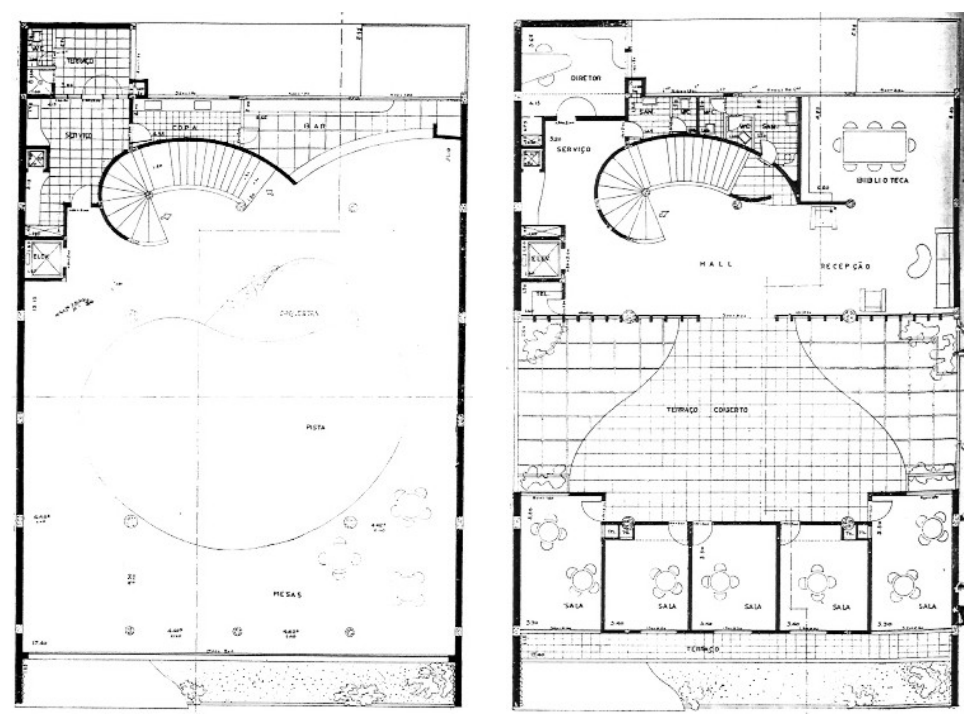

Figs. 38-39: Plantas - 1‥ Pavimento e $2^{\circ}$. Pavimento

\section{Associação Bahiana de Imprensa (A.B.I.) (Salvador/ BA, 1946/ 48 -}

Construído)

Projeto: Zenon Lotufo / Abelardo de Souza / Hélio Duarte.

Fontes: Acrópoles, jun 46, P. 53-55 e n.117, jan 48, P-249-251.

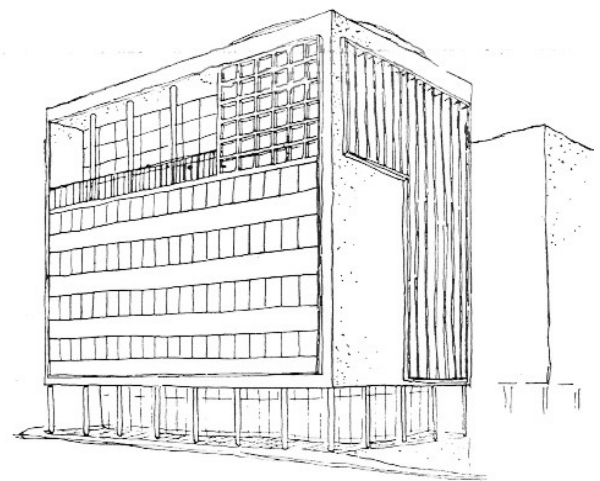

fig. 40

Vencedor do concurso público nacional para a sede da Associação

Brasileira de Imprensa em Salvador a ser construído inicialmente em lote na rua Visconde do rio Branco e Rui Barbosa. 0 projeto respeitava o gabarito dos edifícios vizinhos comportando-se num volume cúbico e compacto.

Programa: 0 térreo estava solto do solo por uma galeria sob pilotis, com lojas comerciais em amplo passeio coberto para pedestres. Os quatro primeiros pavimentos estavam definidos por andares-tipo com salas de escritório e janelas corridas "em tira" na horizontal. Os quinto e sexto andares destinavam-se à sede propriamente dita com salão para leituras, 
auditório e administração. A cobertura era ocupada pelo restaurante com desenho livre e amplo terraço-jardim. A circulação vertical do prédio estava definida por uma caixa retangular na parte posterior do prédio contando com 2 elevadores e caixa de escada.

(Figs. 41-45)

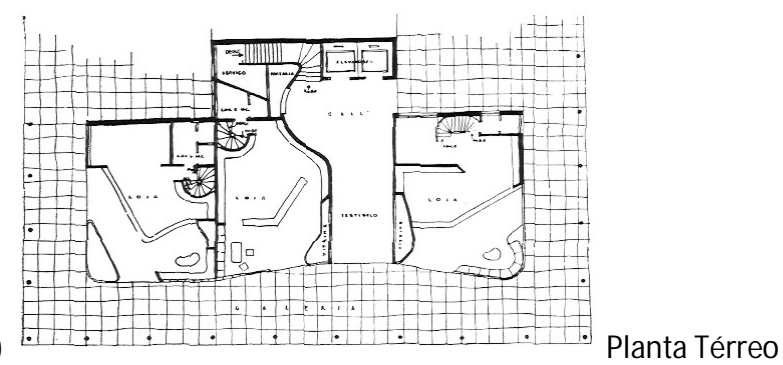

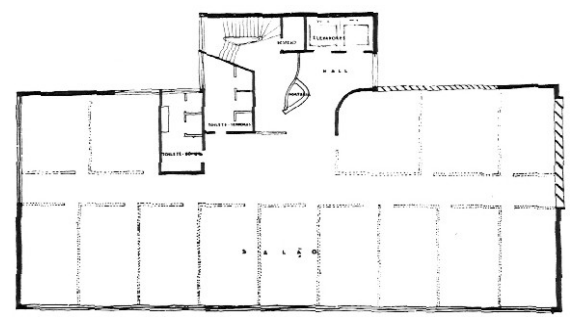

Planta $1^{\circ}$. ao $4^{\circ}$. andar

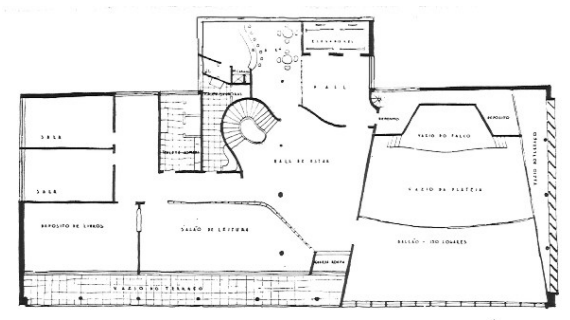

Planta $6^{\circ}$. andar

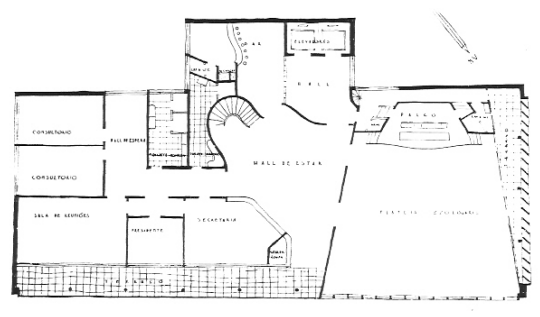

Planta $5^{\circ}$. andar

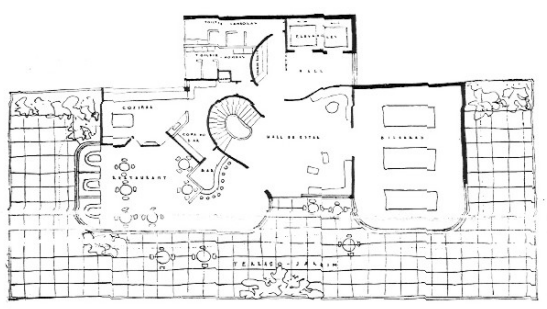

Planta Cobertura
A revisão deste projeto vencido anteriormente (46) pela equipe de arquitetos ocorreu em virtude da mudança da localização para terreno na Praça da Sé, no centro de Salvador. O programa permaneceu basicamente igual ao anterior apenas devendo se adequar ao Plano de urbanização vigente na época.

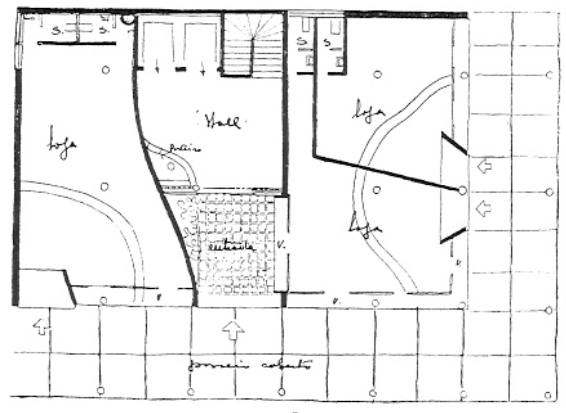

(Figs. 46-53) Planta Térrea - Lojas

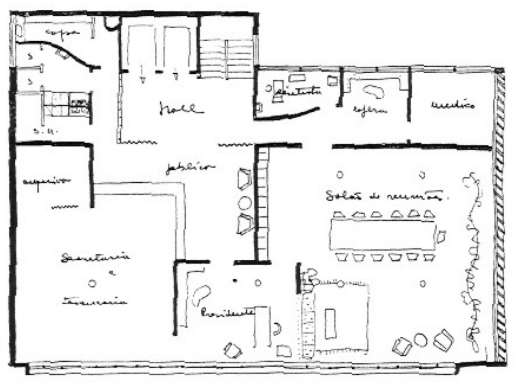

Planta $4^{\circ}$. andar - Administração

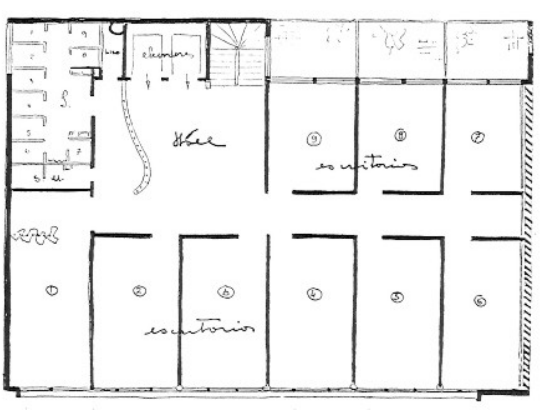

Planta $1^{\circ}$. ao $3^{\circ}$. andar - Escritórios

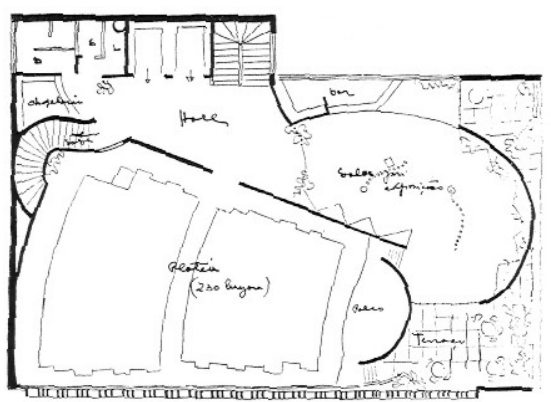

Planta $5^{\circ}$. andar - Auditório e exposições 


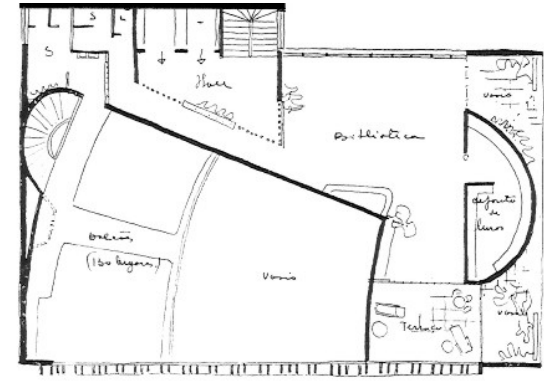

Planta $6^{\circ}$. andar - Biblioteca

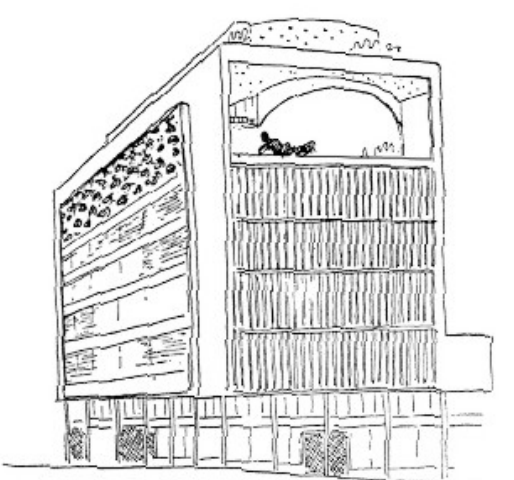

Perspectiva

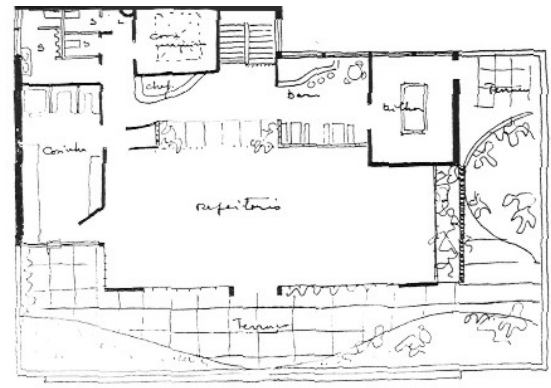

Planta $7^{\circ}$. andar - Restaurante

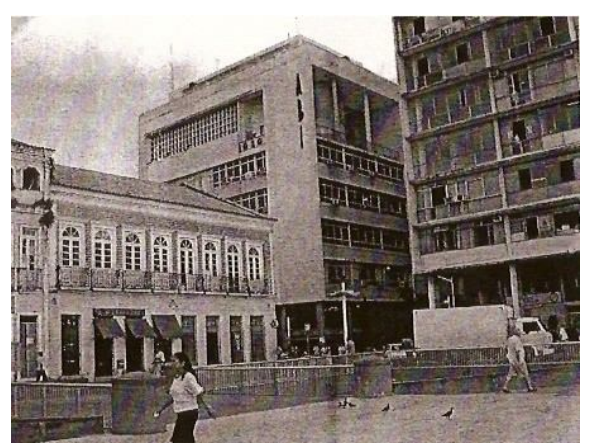

Foto externa
Estância Hidromineral Hotel-Cassino (S. Bárbara do Rio Pardo/ SP, 1946)

Projeto: Zenon Lotufo / Abelardo de Souza / Hélio Duarte

Fonte: Acrópole, julho 46, pp. 80-81.

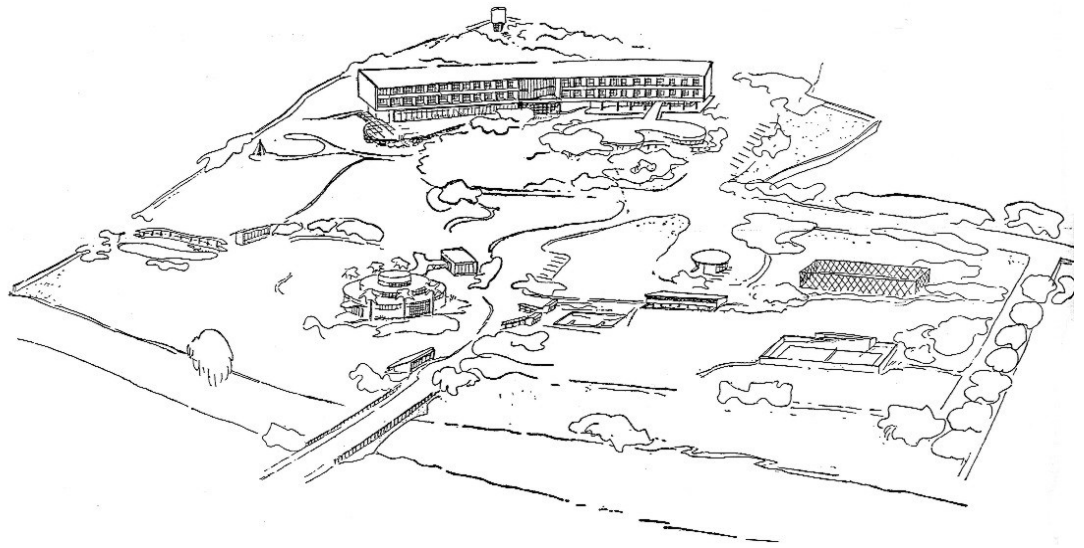

(fig. 54)Perspectiva do conjunto.

0 projeto ocuparia uma ampla gleba às margens do Rio Pardo, sendo previstas diversas instalações e atividades recreativas, sendo as principais: um Hotel com 98 apartamentos e amplo restaurante avarandado e um Casino para jogos e diversões em anexo. Os desenhos do projeto ilustram a predominância da linha curva. 0 volume do Hotel alonga-se horizontalmente numa sutil curvatura onde os quartos abrem-se em varandas privativas e olham para a vista do rio. As formas utilizadas para o Casino remetem ao projeto contemporâneo da época: o Hotel da Pampulha (obra não executada de 1940), de Oscar Niemeyer. 

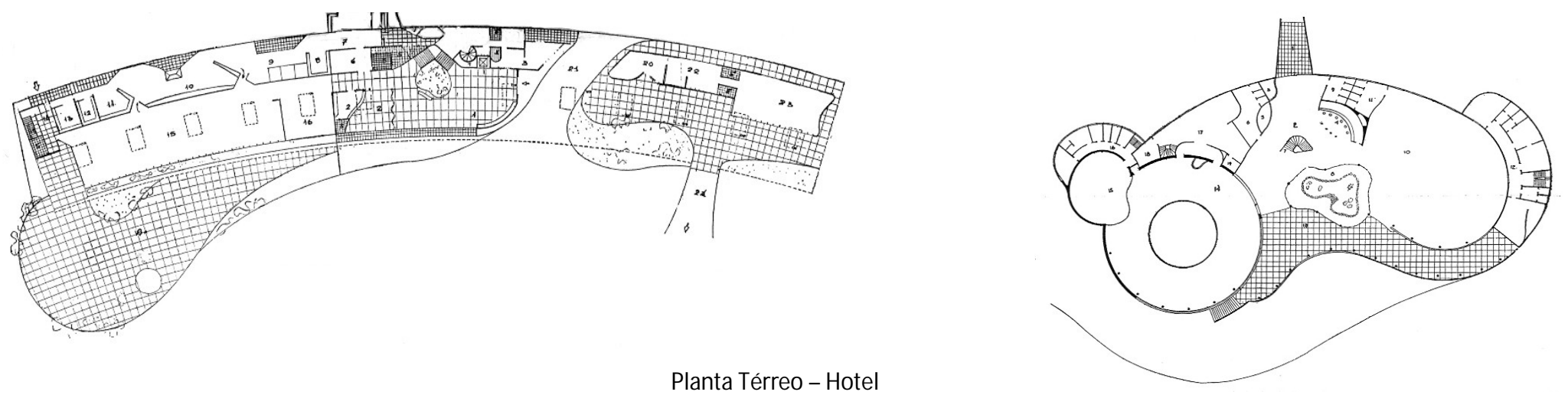

Planta Térreo - Hotel

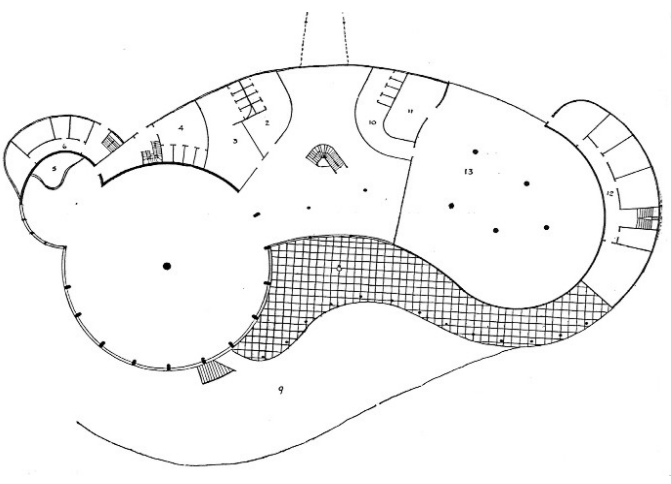

Planta Térreo - Cassino

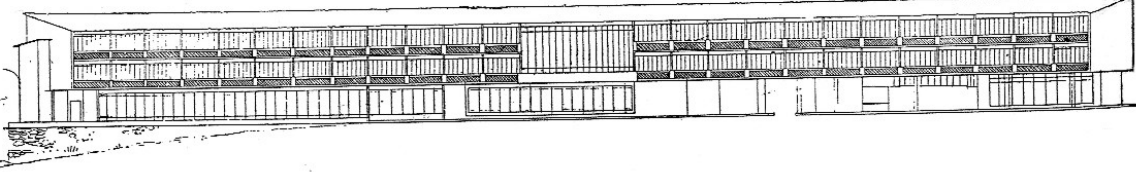

Elevação - Hotel

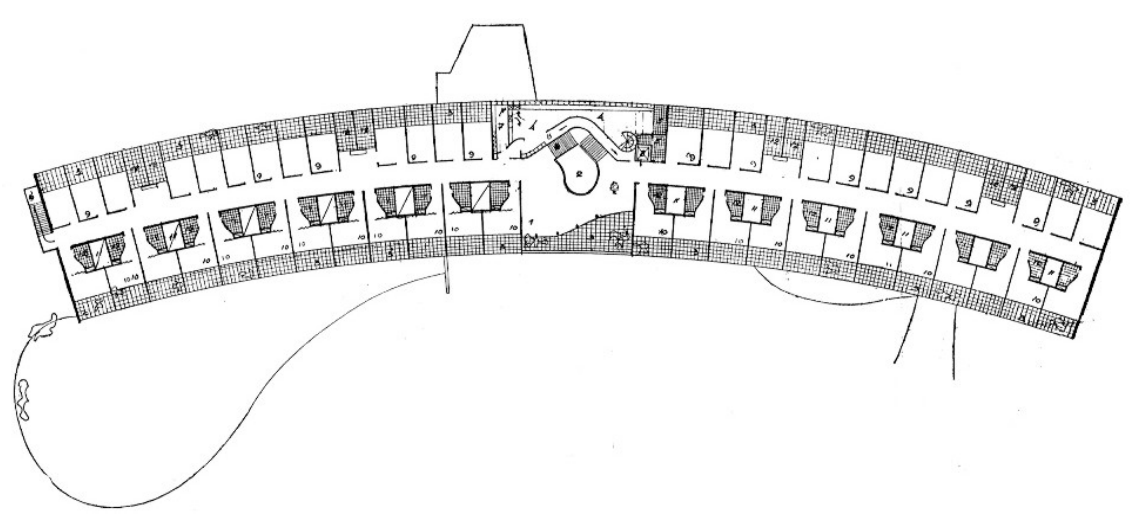

Planta Superior - Cassino

(figs. 55-59)

Plantas $1^{\circ}$ e $2^{\circ}$ Pavimentos - Hotel 
Cruz Vermelha do Brasil (São Paulo/ SP,1946 - Não Construído)

Projeto: Zenon Lotufo / Abelardo de Souza / Hélio Duarte

Fonte: Acrópole 103, nov. 46, pp. 200-202.

Projeto realizado pela equipe de arquitetos para o prédio da sede social e filial de São Paulo da Cruz Vermelha do Brasil. Situado em terreno

irregular, o projeto previa uma caixa de circulação horizontal localizada na parte central e grande hall de distribuição, com 3 elevadores e escada de segurança.

Programa: Térreo: Galeria sob pilotis com lojas comerciais e passeio coberto para pedestres; $1^{0}$. ao 13 - Andar: Salas amplas de escritório com janelas moduladas; 140 Andar: Atendimento e ambulatório; $\mathbf{1 5}^{\circ}$. Andar: Administração e salas de aula; 16을 Andar: Auditório e bar-restaurante com terraço-jardim; $\mathbf{1 7}^{\mathbf{0}}$, ao $\mathbf{1 9}$ Andar: Salas.

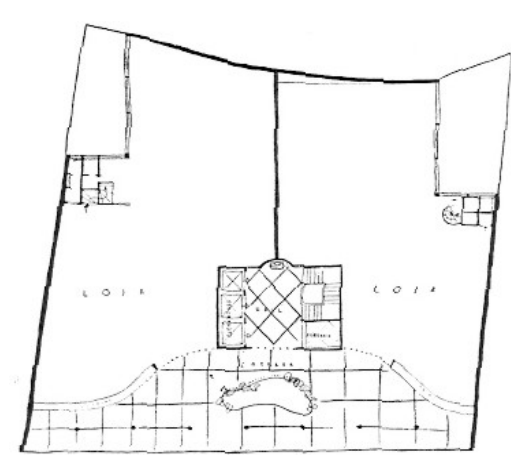

Planta Térreo - Lojas

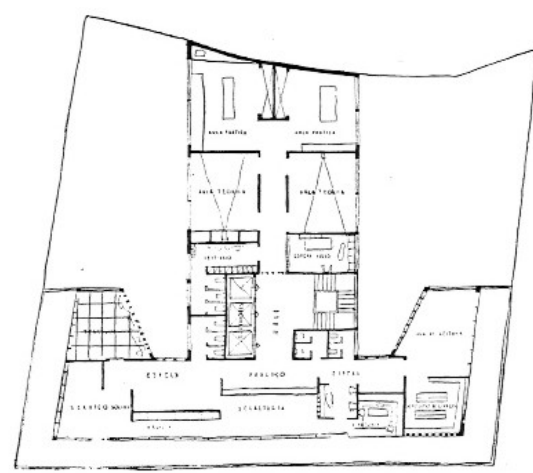

Planta - $15^{\circ}$ Andar

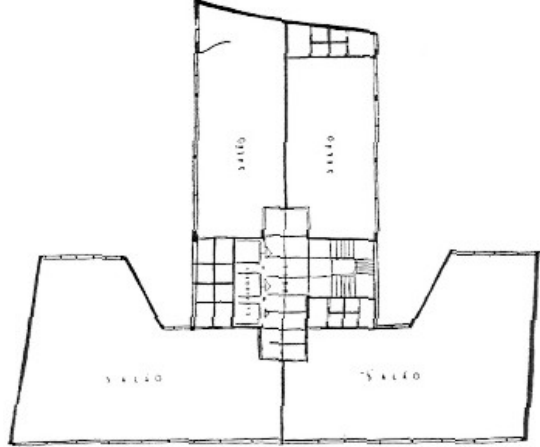

Planta $1^{\circ}$. ao $13^{\circ}$. Andar - Salas

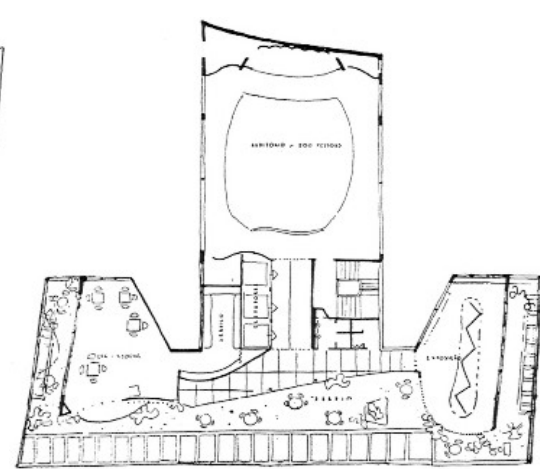

Planta - $16^{\circ}$ Andar (figs. 60-63) 


\section{Edifício Pedra Azul (São Paulo/SP, 1947 - Construído)}

Projeto: Zenon Lotufo / Abelardo de Souza / Hélio Duarte

Proprietário: Sociedade Imobiliária América Ltda.

Fonte: Acrópole 114, out 47, pp.165-167.
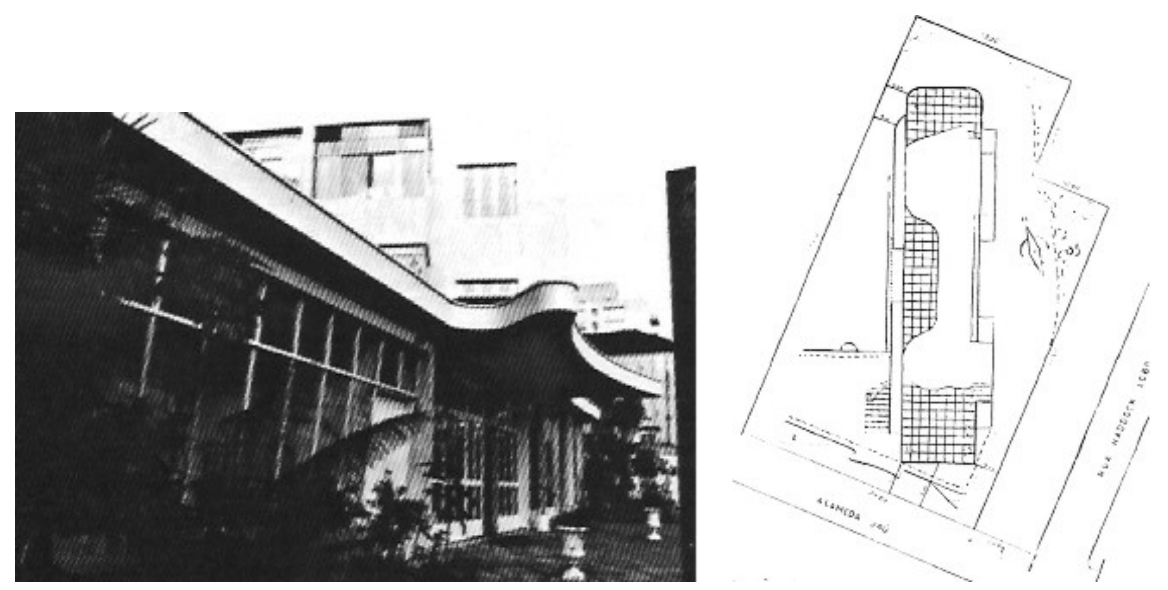

(figs. 64-65) Foto entrada e implantação.

Resultado de um concurso privado, este edifício de apartamentos com 9 andares situado em terreno de $1.200 \mathrm{~m} 2$, no Jardim América, entre as ruas Alameda Jaú e Haddock Lobo apresenta uma ocupação na diagonal do sentido do lote com o intuito de aproveitar as melhores condições de insolação e ventilação. No térreo, uma ampla marquise com desenho curvo orienta a entrada no hall de circulação do prédio. Com uma plantatipo de 4 apartamentos por andar, a circulação vertical distribui-se em 2 caixas localizadas na face leste do edifício, bem como os blocos de hidráulica.

\section{Programa: Térreo: Salão social e apartamentos; Andar tipo: 4} Apartamentos (2 Dormitórios / Sala de Jantar / Sanitário / Cozinha / Dispensa / Terraço e W.C.); Cobertura: Terraço Coberto e Descoberto / Casa de Máquinas / Apartamento do Zelador.

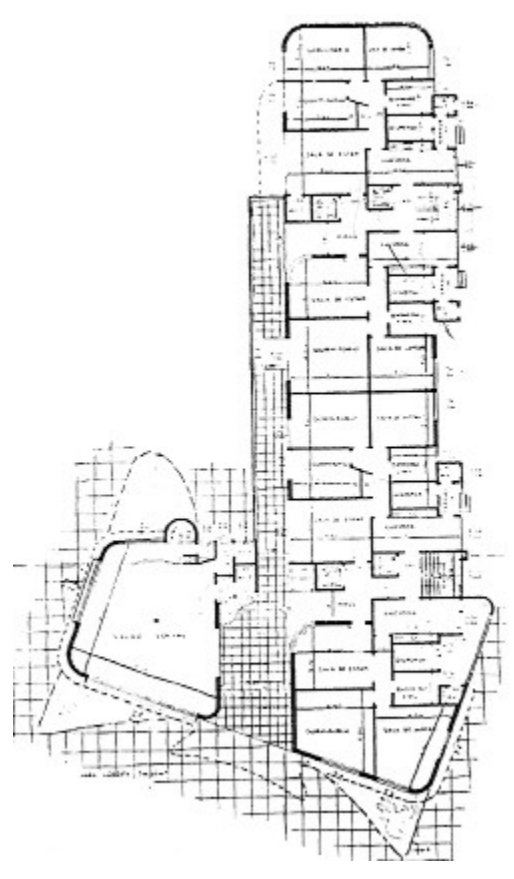

Planta Térreo

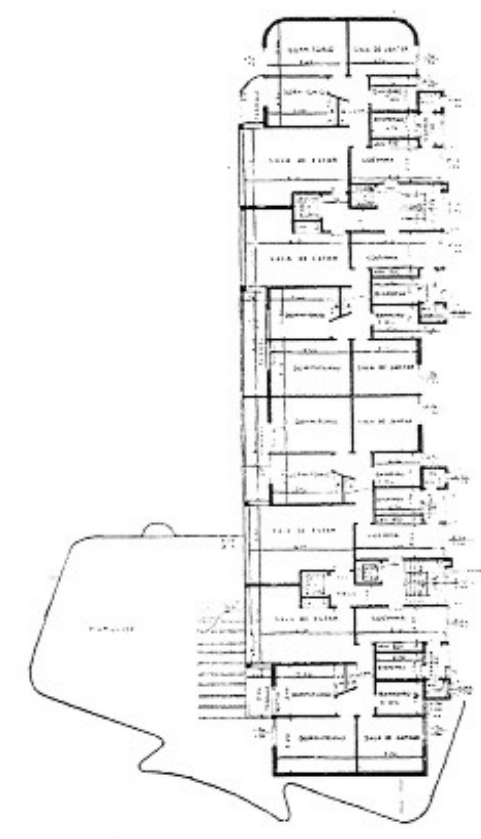

Planta - Andar Tipo (figs. 66-67) 
Instituto de Puericultura (Rio de Janeiro/ RJ, 1947 - Não construído Concurso nacional $-1^{\circ}$ lugar)

Projeto: Zenon Lotufo / Abelardo de Souza / Hélio Duarte

Fonte: Acrópole, jun 48, pp.66-67.

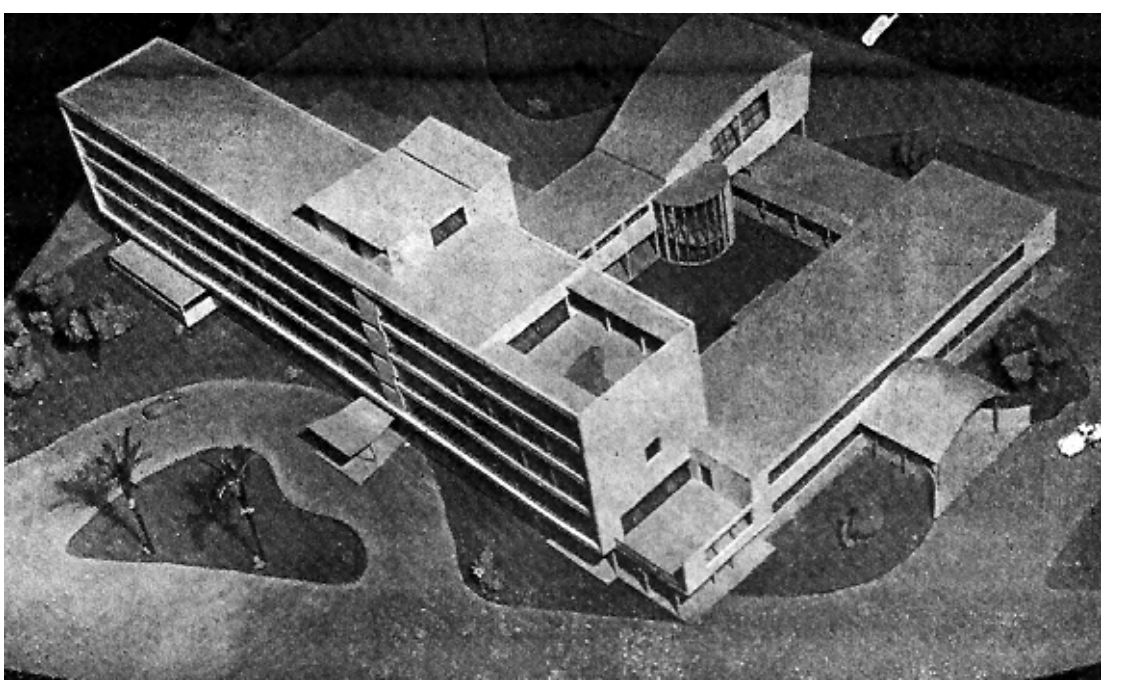

(fig. 68) Foto maquete

Vencedor de concurso público para sede do Instituto de Puericultura da Universidade do Brasil (atual UFRJ) na então Capital Federal previa instalações para o ensino e pesquisa (atividade acadêmica), bem como cuidados à criança e ao adolescente (assistência médica-hospitalar e ambulatorial). A composição arquitetônica do grupo explorava a relação entre blocos de características distintas: um racional e horizontal (corpo principal) e outros, em anexo, variando de altura e direção, tendo em

\footnotetext{
uma de suas extremidades um arremate em cobertura curva. Este tipo de
}

jogo com os volumes, ora alongado e puro, ora mais livre e solto, tornouse uma marca na arquitetura concebida pelos arquitetos. 0 projeto não foi executado, sendo substituído por outro de autoria de Jorge Machado Moreira, situado na ilha do Fundão, em 1949.

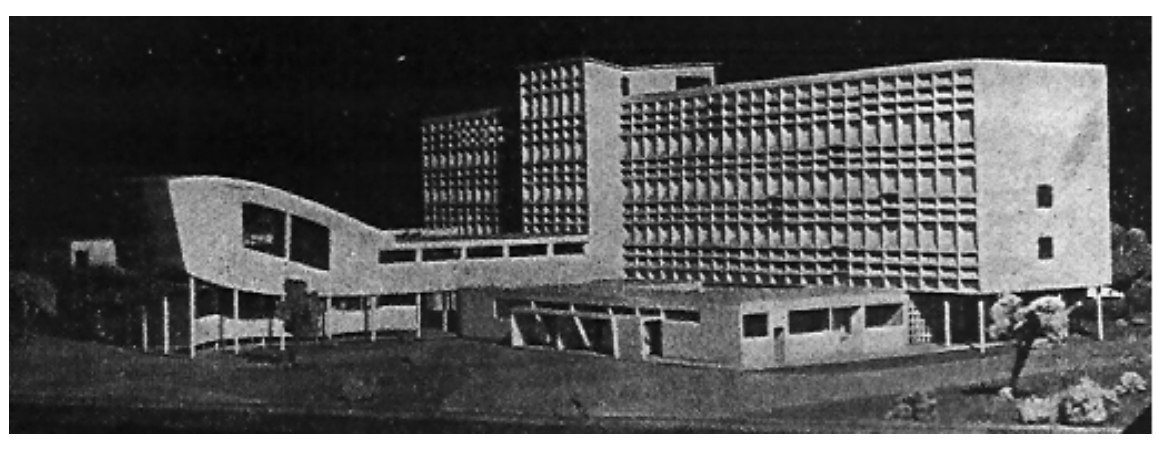

(fig. 69) Foto maquete 
Orfanato Amando de Barros (Botucatu/SP, 1947 - Não construído)

Projeto: Zenon Lotufo / Abelardo de Souza / Hélio Duarte.

Fonte: Acrópole 106, fev 47, pp. 256-257.

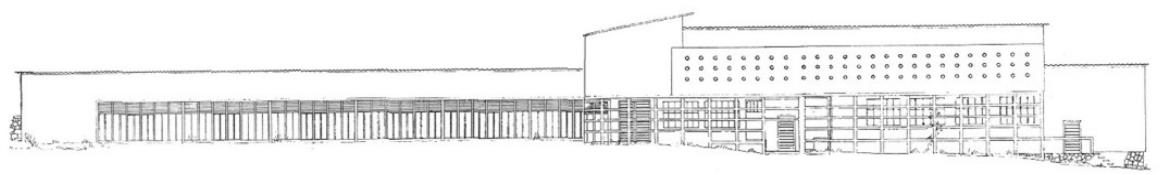

(Figs. 70-72) Elevação Frontal

Com fachada frontal de aproximadamente 80 metros, este projeto situarse-ia à Rua Rafael Sampaio, no município de Botucatu, interior de São Paulo. A disposição em " $\mathrm{T}$ " das plantas no terreno privilegiou a formação de pátios para atividades recreativas externas, além de favorecer 0 conforto térmico criando amplas áreas de ventilação e insolação. Volumetricamente, o projeto chama a atenção para o uso de elementos vazados situados em posições diferentes na fachada, o que contribui para a riqueza e variedade da composição do edifício.

Programa: Térreo: Salas de aula e trabalho / Biblioteca / Capela (à direita) / Refeitório / Recreio Coberto / Pátios abertos. Superior: Dormitórios /

Vestiários / Sanitários / Enfermaria / Apartamentos (à direita) / Varanda.

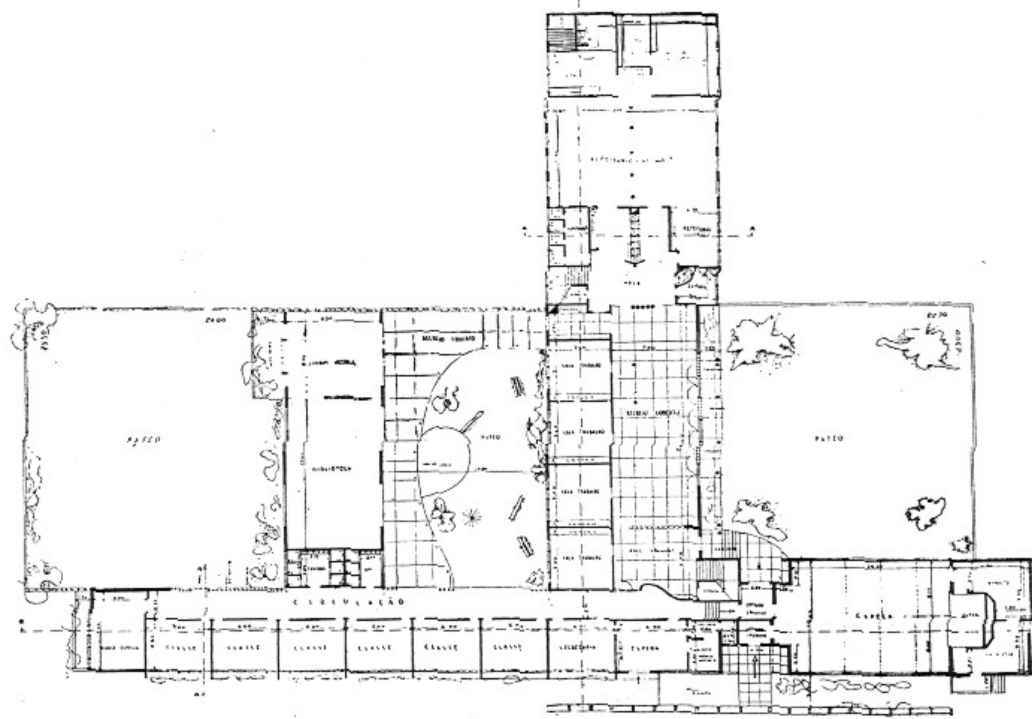

Planta Térreo

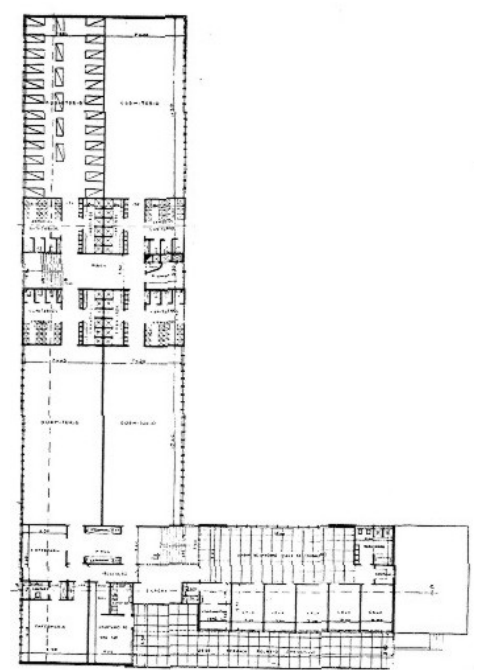


Cerâmica São Caetano S/ A (São Caetano/SP, 1947 - Não construído) Projeto: Zenon Lotufo / Abelardo de Souza / Hélio Duarte.

Construção e idealização: Roberto Simonsen.

Fonte: Acrópole, 48.

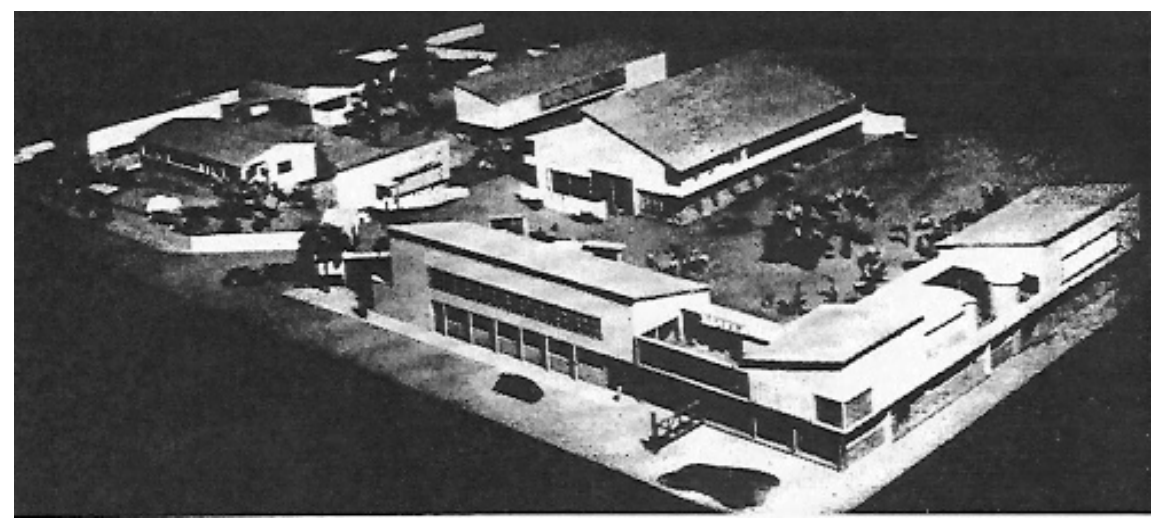

(fig. 73) Foto maquete

Projeto ambicioso e visionário do empresário Roberto Simonsen que vislumbrou, um ano antes de sua morte (em 1947), este complexo de atividades produtivas e fabris. Localizado em amplo terreno na periferia do município de São Caetano, o plano previa a organização e eficiência dos profissionais e operários que ali desempenhariam suas funções. Com uma produção diversificada de materiais cerâmicos como pisos, paredes e tijolos, o projeto abrangia as instalações sociais como escola do Senai, ambulatório geral, refeitório para funcionários, salão de festas, escritório e guarita de acesso. Foi prevista a utilização dos próprios materiais produzidos pela fábrica na construção e execução do projeto a fim de obter uma maior economia e um bom efeito arquitetônico na composição dos volumes e no contraste de cores.

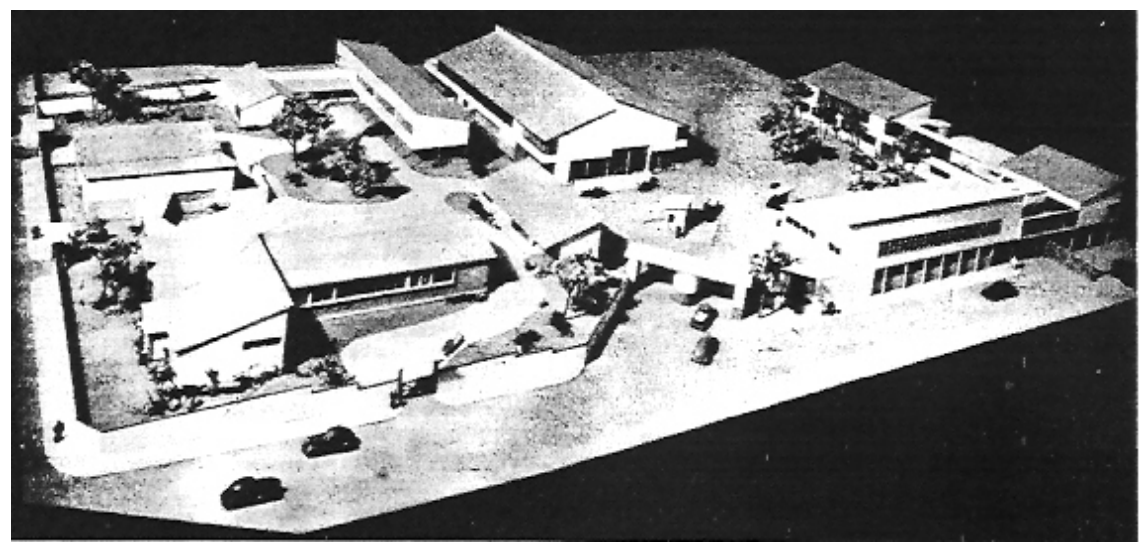

(fig. 74) Foto maquete 
Edifício Hecilda (São Paulo/SP, 1948 - Construído)

Projeto: Zenon Lotufo / Abelardo de Souza / Hélio Duarte

Fonte: Acrópole, abril 48, pp.321-323
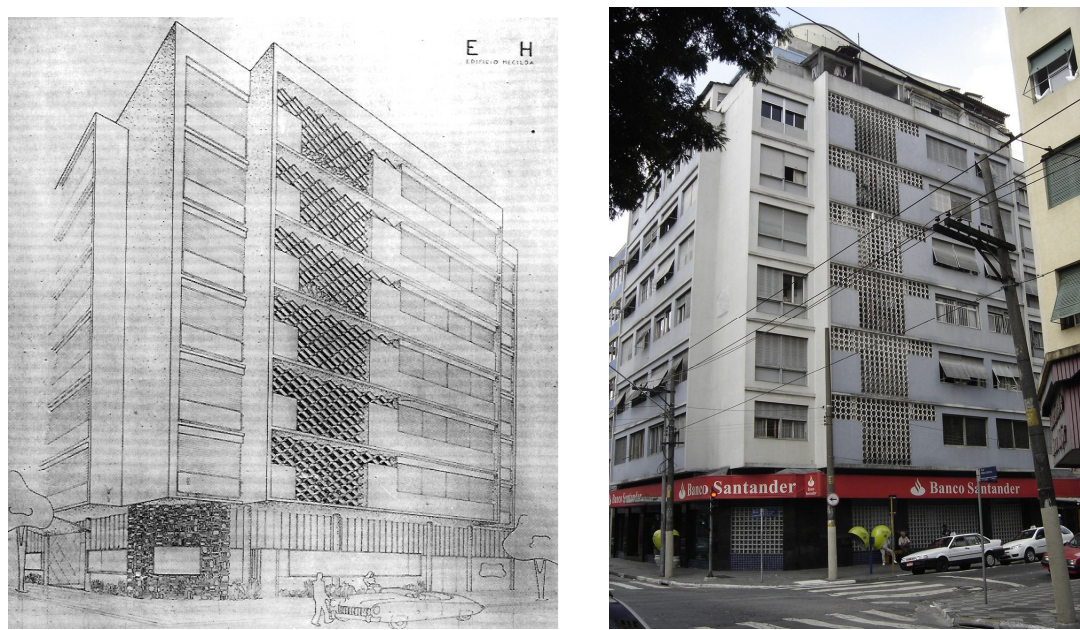

(Figs. 75-76) Perspectiva e Foto externa. Fonte: EM F. Com área total aproximada de $2.500 \mathrm{~m} 2$, este edifício de apartamentos situa-se na esquina entre as ruas M ajor Sertório e Cesário M otta, na região central paulistana. Com 8 andares, o prédio apresenta uma ocupação do lote em "L" distribuindo-se em planta de 3 apartamentos por andar salvo o último andar onde existem apenas 2. Assim, os apartamentos tem tamanhos diferentes, variando o número de dormitórios. Destaque para o uso de elementos vazados (tipo cobogós) na área de serviços e o desenho curvo da casa de máquinas na cobertura.
Programa: Térreo: Hall de entrada / Lojas comerciais; Andar tipo:

Apartamentos (1, 2 ou 3 dormitórios / Banho / Cozinha / Área de serviço / Sala de estar).

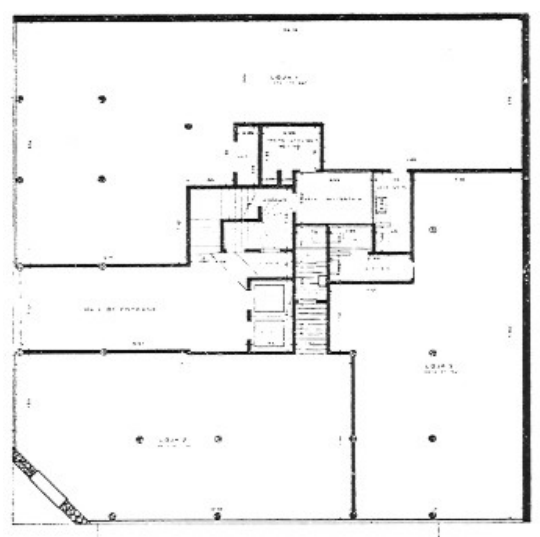

Planta - Piso Térreo (Lojas)

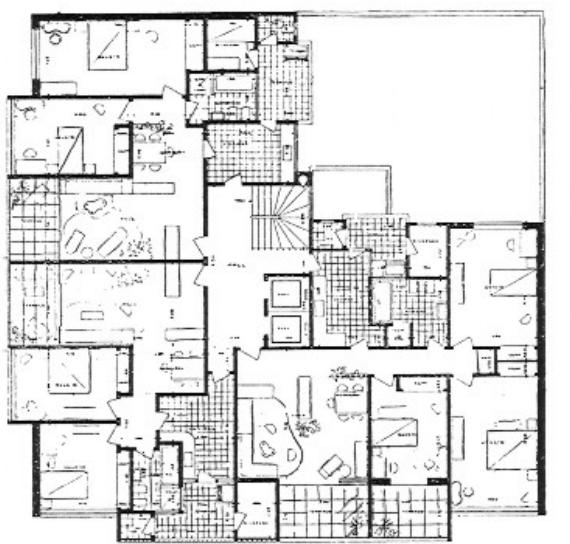

Planta - $1^{0}$ ao $6^{\circ}$ Andar

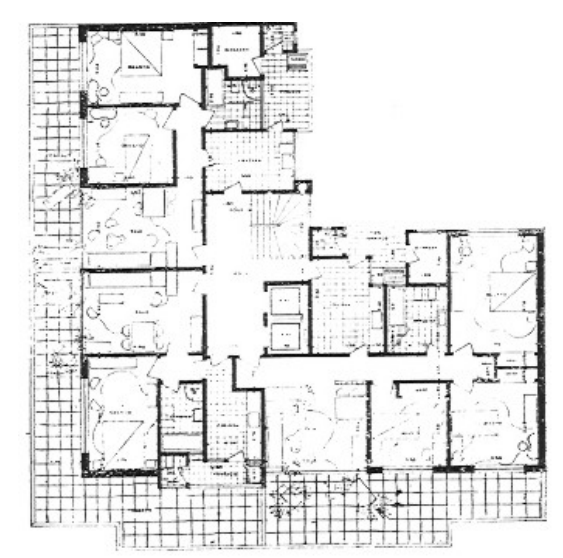

Planta - $7^{\circ}$ Andar

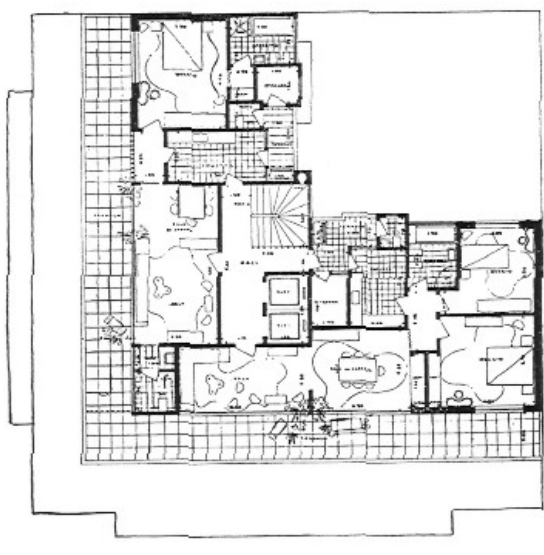

Planta - Cobertura (figs. 77-80) 


\section{Demais parcerias}

0 arquiteto Zenon Lotufo realizaria ainda outras parcerias profissionais neste período (49-52): Gregori Warchavchik, Plínio Croce, Roberto

Cerqueira César, İcaro de Castro de Mello, entre outros, como mostramos a seguir.

\section{Clube Atlético Paulistano (São Paulo/SP, 1949 - Construído)}

Projeto: Gregori Warchavchik / Zenon Lotufo / Abelardo de Souza / Hélio Duarte / Henrique Verona Cristófani. Construção: Socied. Comercial e Construtora S.A.

Fonte: Acrópole, jan 58, pp-95-101.

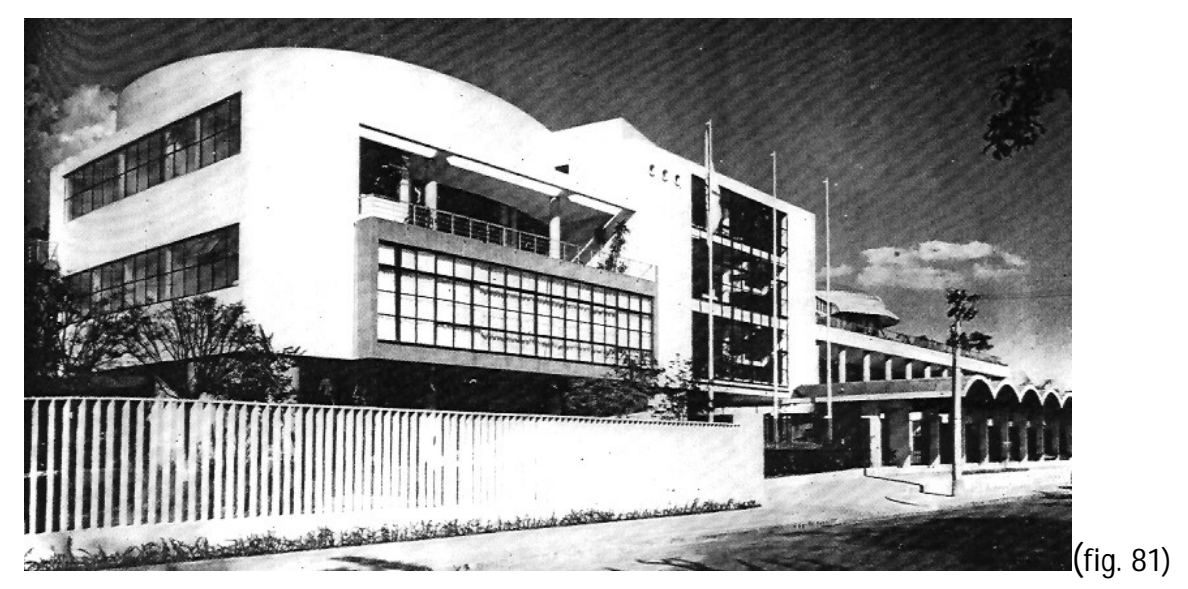

Sede de clube recreativo e esportivo no Jardim Europa, situado à Rua Honduras com Av. Europa. 0 edifício principal é composto em 3 níveis onde o térreo abrigava a marquise de acesso da rua, portaria, rampas, bar e jardim social sob pilotis, barbearia, manicure e médico.

No $1^{\circ}$. Andar abre-se um grande salão social de 19 por $35 \mathrm{~m}$ com terraço respectivo e salões de jogos e bilhares, estar, diretoria e sanitários. No $2^{\circ}$. Andar encontra-se o salão de festas com espaço para orquestra e camarins para artistas e finalmente o mezanino contando com um largo balcão sinuoso. 
Programa: Sede social: Restaurante / Cozinha / Bar / Sanitários / Salão de baile / Foyer / Terraço / Chapelaria / Play-ground (crianças) / Piscinas / Quadras de tênis / Ginásio / Salão de jogos / Jardins.
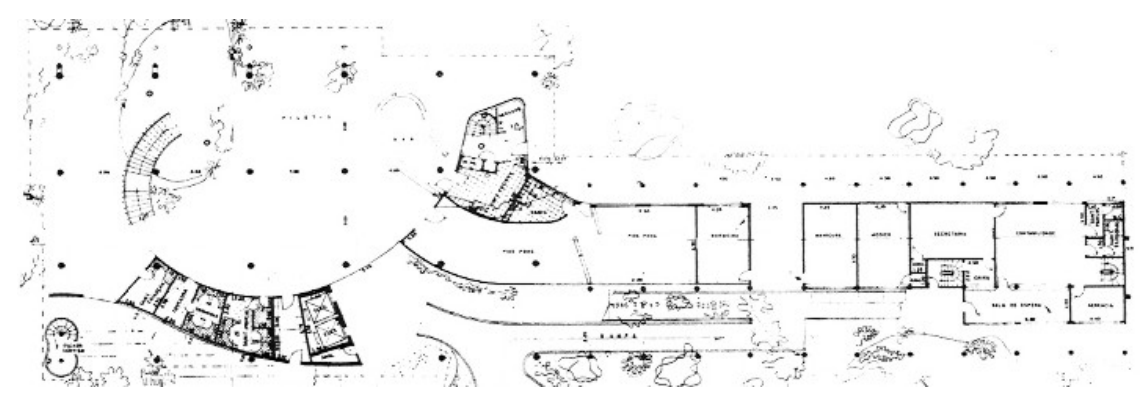

Planta Térreo

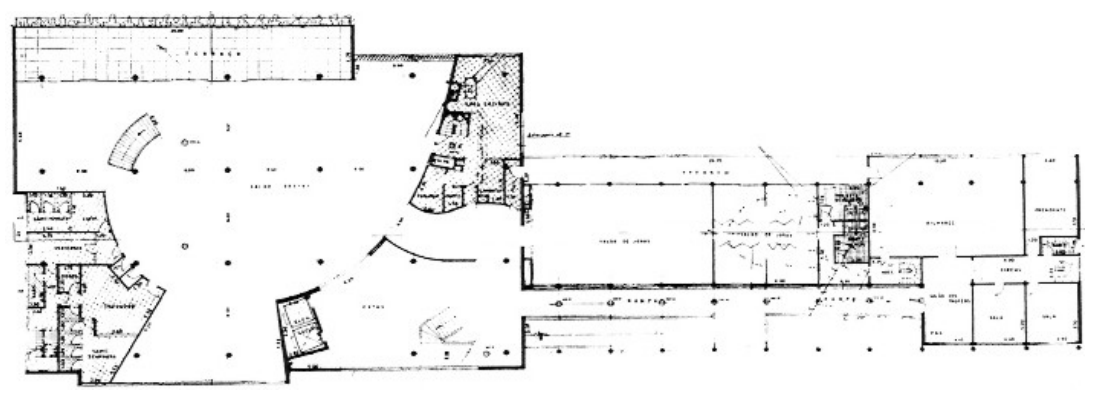

Planta $1^{\circ}$ Andar

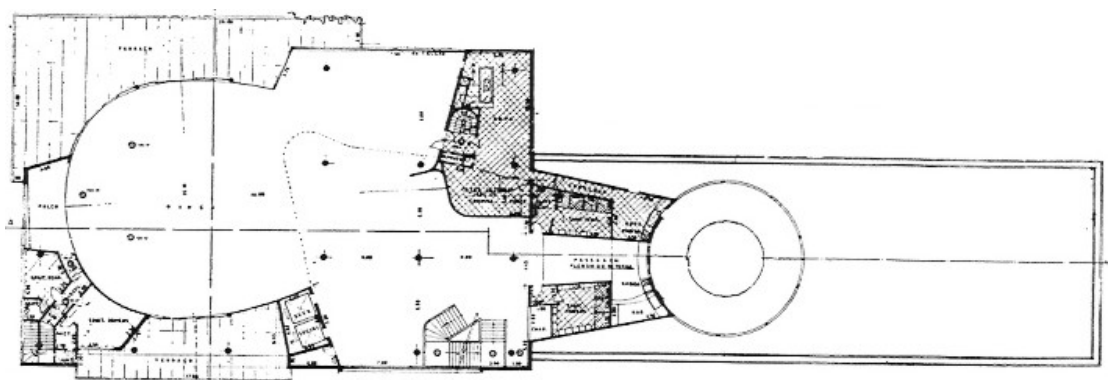

Planta $2^{\circ}$ Andar (Figs.82-84)
Faculdade de Engenharia Industrial (FEI) (São Bernardo do Campo/SP, 1949 - Não construído)

Projeto: Zenon Lotufo / Plinio Croce (colaborador) / Idealização: Padre Roberto Saboia de Medeiros (PUC/SP)

Fonte: Acrópole 137, set 49, pp-146-147.

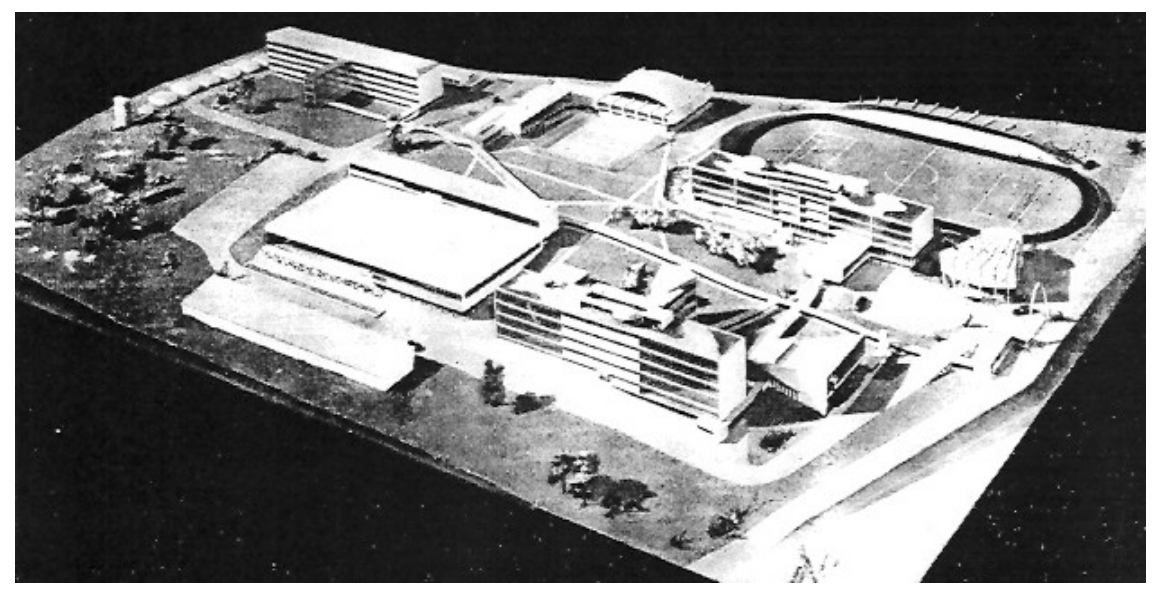

(fig.85) Foto maquete.

Projeto vencedor de concurso privado entre arquitetos para construção da Faculdade de Engenharia Industrial, agregada à Pontifícia Universidade Católica de São Paulo (PUC-SP). Situado em ampla área disponível no km 18 da Via Anchieta, destacando-se pela ocupação racional e distribuição funcional do conjunto no lote e pelas modernas e arrojadas edificações.

Programa: Administração e aulas teóricas / Química / M ecânica / Alojamento de alunos / Clube recreativo / Restaurante / Ginásio / Auditório / Capela / Praça de esportes. 
Associação Cristã de Moços (ACM) (São Paulo/SP, 1952 - Construído)

Projeto: Zenon Lotufo / Roberto Cerqueira César / Ícaro de Castro M ello Fonte: Acrópole 171, jul 52, pp-95.
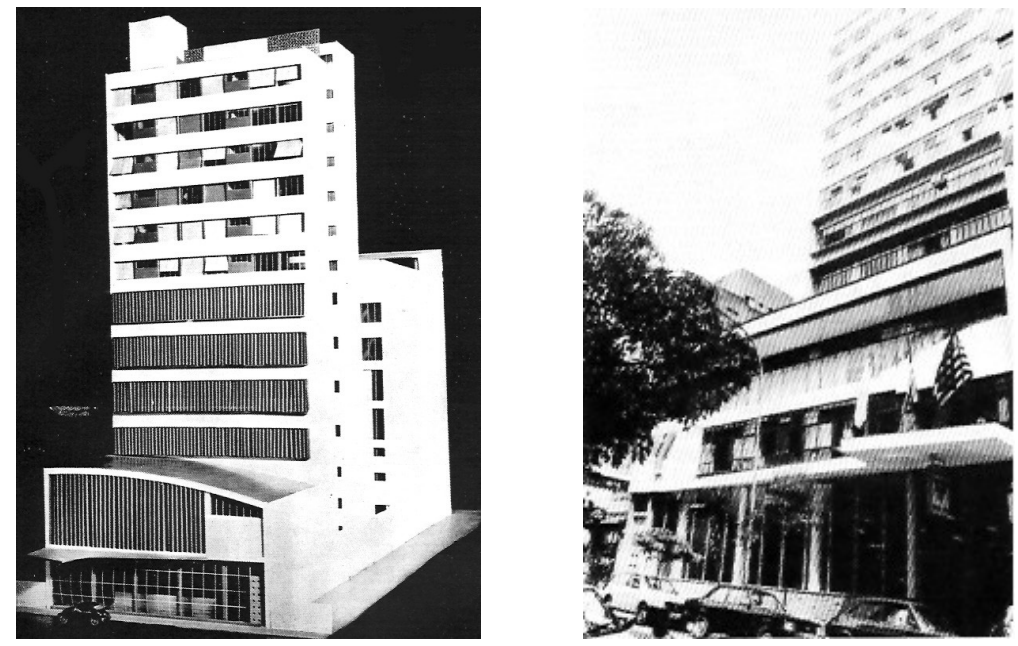

(Figs. 86-87) Foto maquete e externa.

Situado à rua Nestor Pestana, n. 147, este complexo de atividades

esportivas consta também como um edifício de apartamentos em bloco vertical recuado em relação à rua. A história da ACM em São Paulo se dá início em 1902 e tinha como propósito ampliar os ideais fraternais cristãos e oferecer um espaço de reunião e prática para o lazer e o desenvolvimento humano.

Programa: Estacionamento / Lojas / Restaurante / Ginástica / M usculação / Natação / Quadra poliesportiva / Curso de idiomas.

\subsection{A influência de Le Corbusier}

Em abril de 1949, Zenon Lotufo publicou na Revista Acrópole um importante artigo chamado "A Influência dos M estres", onde exaltava a repercussão das idéias e do trabalho de Le Corbusier nele e entre os arquitetos brasileiros.

"A formação mental, espiritual, artística e profissional do indivíduo é resultante de várias componentes, de características diversas, contraditórias ou não, agindo em conjunto ou isoladamente, cada qual procurando modelar sua personalidade. 0 artista age sempre como verdadeiro receptor sensível captando as ondas emitidas pelo mundo externo e revelando-as em seguida, através de suas obras. A palavra influir pode ter a acepção de inspirar, incutir, entusiasmar, excitar. Portanto, o deixar-se influir pelos princípios ou doutrinas de um mestre, não significa ausência de valor próprio, ou que se é um simples imitador". 65

0 arquiteto afirmou a importância para a arquitetura e o urbanismo moderno de nomes como Walter Gropius, Frank Lloyd Wright, Mies van der Rohe e Richard Neutra entre outros que procuravam romper com as sólidas raízes do academicismo do século XIX.

Segundo Zenon, o caminho estaria no seguinte método:

\footnotetext{
${ }^{65}$ LOTUFO, Zenon. A Influência dos M estres. Acrópole, São Paulo, n. 132, abr. 1949, p. 356-357.
} 
“Dado um programa concreto, melhorá-lo tanto quanto seja possível, assegurando-se de que preencha exatamente as necessidades exigidas e depois perguntar ao artista (arquiteto), quando trouxer seus planos, a razão de cada coisa. Pois as regras da arte em arquitetura consistem, sobretudo, em: NADA FAZER SEM RAZÃO" ${ }^{66}$

E posteriormente, 0 arquiteto paulista elogiou a qualidade das realizações de Le Corbusier, segundo ele, o verdadeiro mestre da arquitetura contemporânea.

"Pode alguém não apreciar seus trabalhos, mas não poderá jamais desprezar ou ignorar seus conceitos e sua doutrinação, pois suas palavras são majestrais e sua compreensão do mundo é extraordinária". 67 Para ele, o mestre franco-suíço conseguiu dar forma e expressão às suas idéias de maneira tão nítida, adaptando-as as novas condições sociais modernas, tornando-as dignas de serem observadas.

Zenon observou também neste artigo que o Brasil, ou mais especificamente alguns arquitetos cariocas, como Lúcio Costa e Oscar Niemeyer, haviam sofrido grande influência de suas idéias mediante suas visitas em 1929 (veremos a seguir) e depois em 1936, por conta do projeto do M inistério da Educação, como relatamos anteriormente.

\footnotetext{
${ }^{66}$ Idem.

${ }^{67}$ Ibidem.
}

Depois questionava se a curta permanência de Corbusier no país seria capaz de mudar os rumos da arquitetura brasileira. E respondendo:

"Pelo dedo se conhece o gigante. Mais vale a palavra de um grande mestre do que a cantilena de um medíocre. Uma conferência de Le Corbusier vale um tratado. E tanto vale que aí está o resultado de sua influência: O Brasil se projetando no estrangeiro através de sua arquitetura. $\mathrm{O}$ arquiteto brasileiro compreendeu e apreendeu Le Corbusier. Devem, portanto, nossos arquitetos compreenderem bem suas obras, não no intuito de repetir as formas e soluções ditadas, mas sim, deixando-se influenciar pelo espírito que precede seus trabalhos" ${ }^{68}$

\section{Le Corbusier e o Brasil}

Talvez o fato mais importante para a afirmação e a confiança no movimento moderno na arquitetura brasileira foi a passagem do mestre suíço Le Corbusier pelo país. Sua primeira visita ao Brasil em 1929 coincidiu com a realização de palestras e conferências na América Latina, visita esta que foi fundamental para a disseminação de suas idéias, principalmente no Rio de Janeiro e São Paulo.

0 impacto da natureza e da geografia latinamericana sobre o arquiteto franco-suíço também se fez notável. Seu estudo urbanístico para o Rio de Janeiro (fig. 88) foi uma boa prova disso. Uma mudança considerável de

\footnotetext{
${ }^{68}$ Ibidem.
} 
seu traçado geométrico ortogonal rígido para uma linha fluída e orgânica em forma de edifício que deslizava pela paisagem carioca.

Le Corbusier convencionava assim a Lei do M eandro onde a linha sinuosa dos rios e vales que, vistos de cima, desenhava a beleza tropical do continente sul-americano.

"Olhando o contorno das curvas do rio, entendi as dificuldades inerentes aos assuntos e interesses humanos, os becos sem saída nos quais eles se enredam e as respostas aparentemente miraculosas que repentinamente solucionam situações aparentemente inextricáveis". ${ }^{69}$

(fig. 88)

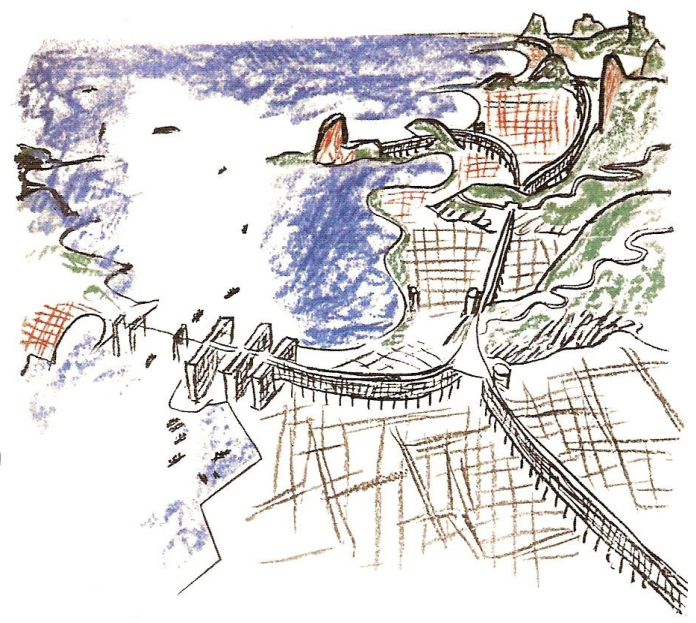

${ }^{69}$ CORBUSIER, L. Precisões sobre um estado presente da arquitetura e do urbanismo. Cosac e Naify, São Paulo, 2004, pg. 18.

\section{0 arquiteto e 0 engenheiro}

Resultado direto dessas intervenções, o livro Precisions retratou algumas das principais idéias do mestre frente à arquitetura e à sociedade industrial. No prefácio da re-impressão do livro de 1960, Le Corbusier colocava que sua busca era restabelecer a harmonia entre o homem e seu meio. Com um belo desenho (fig. 89) finalizava a introdução do livro onde colocava no mesmo plano as funções do arquiteto e do engenheiro, dizendo: "é uma nova etapa que de agora em diante põe em contato permanente, fraternal, igual, as duas vocações cujo destino é equipar a civilização maquinista, e conduzi-la a um esplendor inteiramente novo. Estas duas vocações são a do engenheiro e do arquiteto. São como duas mãos cujos dedos se entrelaçam, duas mãos colocadas na horizontal, duas mãos no mesmo nível". ${ }^{70}$

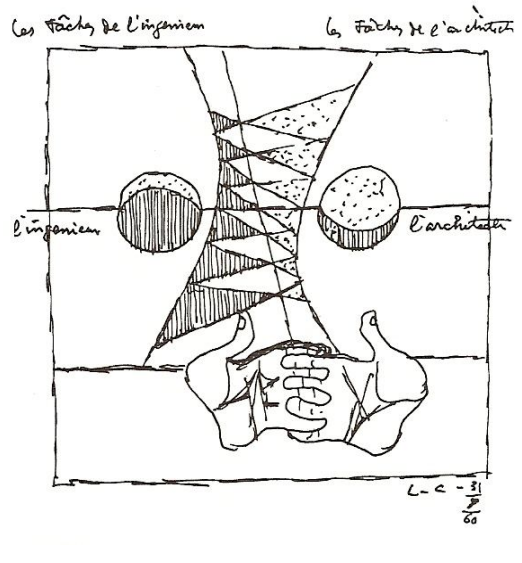

\footnotetext{
${ }^{70}$ Idem, pp. 9-10.
} 
Alan Colquhoun em seu livro Modernidade e Tradição Clássica aponta que a primeira idéia fundamental do livro Vers une Architecture de Le

Corbusier era que o compromisso do arquiteto com os princípios gerais da engenharia moderna, acabaria redescobrindo as origens de sua própria disciplina.

Assim, inicialmente Le Corbusier estabelecia uma clara distinção entre engenharia e arquitetura. 0 objetivo do engenheiro seria fornecer o que é útil, enquanto o do arquiteto deveria despertar a emoção. Em um único sentido, engenheiro e arquiteto partiam dos mesmos fundamentos, pois ambos produziam formas que estão em harmonia com o universo, porém, as diferenças estariam no grau de intencionalidade. Os engenheiros fariam arquitetura, de modo não intencional, fazendo-nos sentir a harmonia, mas é o manipular da harmonia que consistia o trabalho do arquiteto.

“Dessa maneira, se em um sentido o engenheiro e 0 arquiteto partem dos mesmos fundamentos, em um sentido a arquitetura possui seus próprios alicerces, que consistem em sua capacidade de estimular nossos sentidos por meio de formas simples e claras. 0 engenheiro, prosseguindo pela rota do conhecimento, mostra-nos meramente 0 caminho da verdade, enquanto que 0 arquiteto torna tal verdade palpável". ${ }^{71}$

\section{Por uma arquitetura nova}

O famoso livro de Le Corbusier, e talvez o mais influente manifesto arquitetônico do século XX, "Por uma arquitetura" (Vers une Architecture) de 1923, reuniu ensaios da época da revista Espirit Nouveau, de modo a ilustrar seu pensamento. Comparar o conteúdo do seu texto é avaliar seu reflexo nas idéias de Zenon Lotufo.

Inicialmente, Le Corbusier abordou a relação entre o engenheiro e 0 arquiteto, fato que se repetiria em Precisions, apontando as diferenças e as proximidades entre as duas profissões:

"O engenheiro, inspirado pela lei da economia e conduzido pelo cálculo, nos põe em acordo com as leis do universo. Atinge a harmonia. 0 arquiteto, ordenando formas, realiza uma ordem que é pura criação de seu espírito, afeta nossos sentidos; pelas relações que cria, nos dá a medida da ordem do mundo; sentimos então a Beleza". ${ }^{72}$

Para Le Corbusier, a arquitetura estava ligada à emoção do espírito e deveria começar com o emprego de elementos a fim de atingir nossos

\footnotetext{
${ }^{71}$ Colquhoun, Alan. Modernidade e Tradição Clássica: Ensaios sobre Arquitetura. Cosac e Naify, São Paulo, 2004, p 106.

${ }^{72}$ Corbusier, Le. Por uma arquitetura. Editora Perspectiva, São Paulo, 1973, pg. 3.
} 
sentidos e desejos. Estes elementos seriam elementos plásticos, formas primárias (esfera, cubo, cilindro, horizontal, vertical, diagonal) que nossos olhos e espíritos poderiam ver e medir claramente.

Suas conclusões eram que o mundo exterior havia se transformado admiravelmente no seu aspecto e na sua utilização, em conseqüência da máquina (indústria). Uma nova óptica fazia-se necessária e uma nova vida social já se realizava a um certo tempo, porém o habitat humano ainda não havia se adaptado a isto.

Sendo a arquitetura (a casa, o templo ou a fábrica) formada por suas respectivas superfícies, ou na maioria dos casos, paredes perfuradas por portas e janelas, Le Corbusier via esses buracos como reveladores de formas. E por sua vez, a planta seria a grande matriz geradora, a única capaz de evitar a desordem e 0 arbitrário.

"Sem a planta, não poderia haver grandeza de intenção e de expressão, nem ritmo, nem volume, nem coerência. Sem planta há essa sensação insuportável ao homem, de informe, de indigência, de desordem, de arbitrário". ${ }^{73}$

Zenon Lotufo compartilhava desta mesma opinião na hora de elaborar uma planta. Seus primeiros estudos, segundo seu filho Vitor, buscavam sempre articular todos os elementos do projeto em um organograma

\footnotetext{
${ }^{73}$ Idem, pg. 27
}

preliminar coerente e lógico, ponto de partida para a definição de seus projetos. $^{74}$

\section{Traçados reguladores}

Talvez o fato que mais comprovaria a apropriação corbusiana dos princípios clássicos na arquitetura seja o que ele chamou de "traçados reguladores".

Tratava-se de um princípio de ordem, segundo ele, onde a escolha do traçado regulador (plano) e suas modalidades de expressão (módulos) fariam parte integrante da criação, sendo operação fundamental para se alcançar harmonia na arquitetura.

“Para se construir bem, há medidas para repartir os esforços, para a solidez, para a utilidade da obra. As medidas condicionam o todo. 0 construtor tomou como medida, o que lhe era mais fácil, mais constante, o instrumento que podia perder menos: seu passo, seu pé, seu cotovelo, seu dedo". ${ }^{75}$

Assim, o homem e sua capacidade de medir criaram módulos e unidades de medida que regulavam suas obras, a partir da sua escala, estabelecendo assim a noção geométrica de ordem. Para Le Corbusier, ao decidir a forma do cercado ou da cabana, ou mesmo a posição de um

\footnotetext{
${ }^{74}$ Entrevista concedida por Vitor Amaral Lotufo, em Botucatu em 26 de janeiro de 2007.

${ }^{75}$ Ibidem, pg. 44.
} 
altar ou templo, o homem teria seguido seus instintos através de ângulos e eixos, criando figuras como o quadrado e o círculo.

Desta maneira, a geometria seria a verdadeira linguagem espacial do homem onde o módulo (pé ou passo) teria a função de medir, enquanto que o traçado regulador (plano e eixos) construiria a agradável percepção de ordem.

Para Le Corbusier, isto era necessário: estabelecer padrões de eficiência para se alcançar a perfeição. E, portanto, a boa arquitetura se realizaria sobre esses padrões.

“Padrões são coisa de lógica, de análise e estudo, estabelecidos a partir de um problema bem colocado. É o estudo aprofundado das partes. É progresso. Uma necessidade de ordem trazida para o trabalho humano. Todos os homens têm o mesmo organismo, as mesmas funções e as mesmas necessidades. Estabelecer um padrão é esgotar todas as possibilidades práticas e razoáveis, deduzir um tipo reconhecido conforme as funções, com rendimento máximo, e emprego mínimo de meios, mão de obra, palavras, formas, cores e sons". ${ }^{76}$

O estabelecimento de um padrão procederia da organização de elementos racionais conforme uma linha de conduta igualmente racional. A massa envolvente não seria preconcebida, apenas resultaria desta organização.

${ }^{76}$ Idem, pg. 89.
Portanto, em arquitetura, a eficiência de uma obra só seria atingida pelo agrupamento e a proporção correta das partes: tarefa do arquiteto. Onde a Beleza seria algo incomensurável que surgiria somente pela presença formal de bases primordiais: a satisfação racional do espírito (utilidade e economia) e as formas puras e sensoriais, como o cubo e o cilindro.

Depois, as relações que criam o inesperado são o gênio inventivo (plástico e matemático) do arquiteto, aliado à sua capacidade de relacionar ordem e unidade, e de organizar segundo leis claras, coisas que satisfazem nosso espírito.

Portanto, para Corbusier, a harmonia seria um estado de concordância entre partes distintas, de acordo com as normas do Universo e a Beleza seria uma criação puramente humana, fundamental àqueles de alma elevada. Tais idéias já estavam presentes nos tratados clássicos de Guadet e Durand, sendo fortemente apropriadas por Zenon Lotufo tanto em seus textos e teses, como em seus projetos.

\section{Estudo atento da história}

Muito das idéias de Le Corbusier vieram também de sua atenta observação da história das cidades, aliada a uma visão utópica do momento presente. Constantemente acusado de revolucionário, o mestre franco-suíço confessava que na realidade tivera apenas um único mestre - o passado, e apenas uma disciplina - o seu estudo. 
A grandeza das invenções do passado (tradição) deveria ser repetida não por imitação, mas por re-interpretação de suas constantes e a busca pela sua equivalência, em termos modernos.

Os objetos tenderiam a representar um tipo que seria determinado pela evolução das formas entre o ideal do máximo de utilidade e as necessidades de economia que conformam as leis da natureza. Seria preciso invocar todos os valores tradicionais da arquitetura e envolvê-las através da memória.

Para Le Corbusier, quando o homem fazia o uso da memória e do raciocínio surgiriam certas relações que agitam sua consciência, deixando em estado de regozijo. Portanto, intuição seria a soma do conhecimento adquirido que ficava gravado na memória coletiva. E o sentimento seria a expressão desse conhecimento gravado. Assim, intuição e sentimento não seriam antagônicos à razão. Seriam, na verdade, a própria razão sob seus aspectos instintivo, sensorial e emotivo.

0 mestre suíço via que era peculiar à engenharia, produzir resultados provisórios, enquanto que a obra de arte apresentava-se como valor atemporal. Assim, a indústria seria resultado do raciocínio abstrato, prático e funcional, e não, da emoção e do espírito.

\section{A ilusão das plantas}

"A planta procede de dentro pra fora, o exterior é o resultado de um interior. Os elementos da arquitetura são a luz e a sombra, a parede e o espaço. Suas pedras me dizem. Vocês me prendem a esse lugar e meus olhos contemplam algo que anuncia um pensamento. Um pensamento com prismas silenciosos que mantém relações entre si. São a criação matemática do espírito. São a linguagem da arquitetura. Com materiais utilitários, vocês estabeleceram relações que me comoveram". ${ }^{77}$

Para Le Corbusier, fazer uma planta era ordenar e fixar idéias para que se tornassem inteligíveis e executáveis, manifestando uma intenção precisa. A planta seria a geradora e a determinante de tudo e implicaria desde 0 começo em procedimentos de construção. Sem uma boa planta, tudo seria frágil e pobre.

Por sua vez, o eixo talvez fosse a primeira manifestação humana. 0 meio de todo ato humano e o ordenador da arquitetura que indicaria caminho e direção.

"A ordenação é a hierarquia dos eixos, logo a hierarquia dos fins, das intenções. 0 arquiteto confere fins aos eixos. Esses fins são as paredes (o cheio, a sensação sensorial) ou a luz, o espaço. Na realidade, os eixos

\footnotetext{
${ }^{77}$ Ibidem, pg. 125.
} 
não se percebem do alto como mostra a planta, porém no solo, o homem de pé, diante deles". ${ }^{78}$

A questão da composição volta à tona dessa vez com o nome de modenatura, para Le Corbusier, o grande trunfo do arquiteto, e esta qualidade se revelaria através de sua capacidade plástica. Não se tratava de usos, nem tradições ou procedimentos construtivos às necessidades utilitárias, mas do modo como se combinava plasticamente cada parte num todo arquitetônico.

“Um belo rosto se distingue pela qualidade dos traços e um valor particular das relações que os unem. Diz-se que um rosto é belo quando a precisão da modelagem e a disposição dos traços revelam proporções que sentimos harmoniosas, pois provocam em nós uma ressonância que se põe a vibrar. Essa harmonia que satisfaz nosso espírito deve ser o eixo sobre o qual se organiza todo universo, nos leva a pensar uma unidade de gestão e uma vontade única na origem do mesmo". ${ }^{79}$

Daí, portanto uma outra definição corbusiana para harmonia: momento de concordância do eixo em que está o homem com as leis do universo e assim um retorno à ordem geral.
Para ele, seria preciso uma unidade de intenção motriz (ordenação) e um caráter fundamental (algo que excita nossos sentidos) para tornar um "objeto" em obra de arte.

"A modenatura do Partenon é infalível e implacável, seu rigor supera nossos hábitos e as possibilidades normais do homem. Aqui se fixa o mais puro testemunho da fisiologia das sensações e da especulação matemática que se pode prender a elas. Não se trata de dogmas religiosos, de descrição simbólica: são formas puras dentro de relações precisas" ${ }^{80}$

No capítulo final, Le Corbusier constatava que o concreto e o ferro haviam transformado as organizações e os modos de construir conhecidos até então. As precisões com quais estes materiais se adaptaram à teoria e ao cálculo haviam produzido resultados surpreendentes.

A arquitetura se encontraria, portanto, de frente a um novo código onde as inovações seriam de tal ordem que os estilos não correspondiam mais a elas. Para ele, haveria uma tal novidade nas formas, nos ritmos, nas ordenações e nos novos programas que em seu entendimento, as leis verdadeiras e profundas da arquitetura seriam agora o volume, o ritmo e a proporção.

Colocando-se em relação ao passado, Corbusier constatava que a velha codificação da arquitetura, sobrecarregada de artigos e regulamentos

\footnotetext{
${ }^{80}$ Ibidem, pg. 157.
}

\footnotetext{
${ }^{78}$ Ibidem, pg. 133.

${ }^{79}$ Ibidem, pg. 145.
} 
durante quarenta séculos, não mais interessava, tendo chegado a seu fim. Assim, para ele, os estilos não faziam mais qualquer sentido.

O homem moderno (inquieto pelas mudanças que o cercavam) sentiria naquele momento que um novo mundo se elaborava, com lógica e regularidade, produzindo coisas puras e mecânicas. Entretanto, sua casa, seu bairro e sua cidade não correspondiam a toda aquela transformação. Para Corbusier, um grande conflito reinava entre o estado de espírito moderno e o estoque de antiguidades das cidades. No entanto, isso seria apenas um problema de adaptação que dependeria do esforço e atenção que a sociedade daria àqueles sintomas. E proclamava por fim: Arquitetura ou revolução. Ora, podemos evitar a revolução.

\section{Cidade, lazer e espírito}

Para Le Corbusier, as pequenas realizações (casas, villas e estúdios) foram um precioso laboratório de ensaios onde ele expôs seu modo de ver 0 mundo, e seus desejos para a nova cidade industrial.

A estrutura elevada do solo (pilotis) tornou-se para ele o principal instrumento para a mudança social, gerando um novo modo de viver na cidade. Seus espaços livres contínuos por sobre o térreo dos edifícios possibilitaria o trânsito livre das pessoas com a existência de vastos parques interconectados.
Em suas conferências ministradas no Rio de Janeiro em 36, por ocasião do projeto do M inistério da Educação, Le Corbusier enfatizou também que 0 ciclo de horas diárias (fig. 90) deveria satisfazer as necessidades psicológicas e fisiológicas do homem.

Para ele, o dia poderia ser dividido da seguinte forma: oito horas de sono, uma hora para se locomover para o trabalho, quatro horas de trabalho e o resto do dia livre, para atividades de lazer (onze horas), a serem preenchidas com a leitura de grandes obras literárias, ou freqüentando-se laboratórios de criação e arte, dispostos nos cruzamentos das vias urbanas. Os jovens poderiam reunir-se para participar de atividades cênicas e desenvolver seus talentos para as artes. ${ }^{81}$

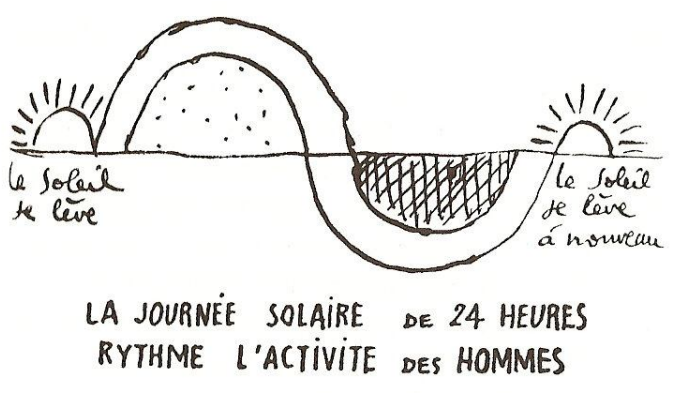

(fig. 90)

\footnotetext{
${ }^{81}$ Harris, Elizabeth. Le Corbusier:Riscos brasileiros. Editora Nobel, São Paulo, 1987, p. 108.
} 
A seguir, aproveitamos também para citar alguns trechos do livro de Anatole Kopp, Quando o moderno não era um estilo e sim uma causa, que destacou a importância da obra do mestre franco-suíço.

"O pensamento utópico de Le Corbusier se compara ao dos que queriam reconstruir simultaneamente a sociedade e seu ambiente construído, esta é a chave principal para compreendermos sua obra arquitetônica e urbanística. Um homem para quem uma nova arquitetura é inseparável de uma transformação radical da sociedade, segundo ele imediatamente possível. Na verdade, ocorre que para Le Corbusier não se trata do ambiente construído; através de seus projetos e de seus escritos assistimos a toda uma reorganização da sociedade, é um verdadeiro projeto social que ele traça". ${ }^{82}$

Le Corbusier tentou resolver conscientemente a contradição entre tecnologia, arte e sociedade, através da união entre a engenharia e a arquitetura. Seu projeto utópico para o Rio de Janeiro (fig.88), por exemplo, tinha o gesto grandioso de um romântico que evoca uma imagem fantasiosa de um mundo tecnológico, transformado em forma pura. Assim, talvez a maior qualidade estética desse projeto estivesse no fato de tentar articular arte e existência social, de um modo não mais conflituoso. Isto era princípio fundamental entre os moderno, herança das idéias propagadas por Corbusier, assimiladas por toda uma geração.

\footnotetext{
${ }^{82}$ Idem, p. 124.
}

\subsection{Niemeyer, Zenon e Ibirapuera (50-55)}

Nos anos 50, a cidade de São Paulo passou por modificações de grande ordem como a redefinição de algumas funções urbanas, a

desconcentração dos bairros tradicionais, a reestruturação do skyline com a maciça verticalização do centro e incremento das instituições culturais rumo a pré-configuração definitiva de metrópole.

Assim, São Paulo perdia de vez seus ares campestres e viam-se erguer as numerosas chaminés de fábricas, a imagem e o som estrangeiro dos imigrantes nas ruas e praças, alterando também o ritmo da cidade antiga. ${ }^{83}$ Babel cultural, cosmopolita, moderna, industrial, amplitude vertical e horizontal, todos estes cenários se faziam úteis para definir o processo de transformação da capital paulista.

Nesta ocasião, Oscar Niemeyer realizava suas primeiras grandes obras na capital paulista e uma destas realizações também se tornaria importante marco da arquitetura moderna em São Paulo: o edifício Copan (1951-66). 0 projeto original encomendado pela Companhia Pan-Americana de Hotéis e Turismo para ser um complexo hoteleiro com cinema, restaurantes, lojas e jardins não foi levado a diante, sofrendo inúmeras alterações até a sua inauguração na década de 60.

\footnotetext{
${ }^{83}$ Arruda, M. A. N.M etrópole e cultura: São Paulo no meio do século XX. Bauru, Edusc, 2001, pg. 56.
} 
0 arquiteto Carlos Lemos foi o principal responsável pelo projeto executivo e a supervisão dos trabalhos, sendo o chefe do escritório paulista de Niemeyer.

"O diretor do Banco Nacional Imobiliário contratou Niemeyer para fazer o projeto do Copan, porém o Oscar precisava de um escritório em São Paulo para coordenar os trabalhos . 0 diretor disse: "Conheço um rapaz novo, bastante talentoso (Carlos Lemos) e assim, pediu para Oscar ligar, e conversar e tal, sei que ele disse precisamos de mais desenhistas, só sei que fiquei varando noite pós noite para entregar o Copan, foi maravilhoso. ${ }^{184}$

Na mesma época (51) começou uma agitação política e cultural em função dos eventos comemorativos para o IV Centenário da Cidade de São Paulo. "Cicillo" Matarazzo tomou a frente na iniciativa de prover a capital com um grande projeto de parque de exposições que abrigasse as festividades e que posteriormente, fosse apropriado para a população com amplo espaço de lazer.

0 terreno escolhido situava-se no Ybi-ra-ouêra, que em tupi significa "pau-podre", ou seja, o local era um pasto pantanoso definido por uma comissão mista entre prefeitura, Estado e iniciativa privada como área ideal para o empreendimento.

${ }^{84}$ Depoimento de Carlos Lemos em 20 de setembro de 2007.
"Ciccilo Matarazzo começou a pensar na Comissão para o IV Centenário e precisava de um arquiteto para projetar os edifícios para a exposição. Inicialmente, convidou Rino Levi e pediu para ele fazer um orçamento para o trabalho. 0 Rino apresentou uma proposta detalhadíssima, com várias páginas, porém o orçamento assustou Ciccillo. Daí, ele ligou pro Oscar: Topa fazer? Sim, e Oscar fechou por menos da metade do valor de Rino. Oscar precisava de uma nova equipe de trabalho em São Paulo. 0 primeiro nome foi o de Eduardo Kneese de M ello, e este por sua vez teria chamado os demais, incluindo aí Zenon, que cedeu 0 espaço do seu escritório na Major Sertório para desenvolvermos os projetos." ${ }^{185}$

Assim, foi encomendado a Oscar Niemeyer, então principal arquiteto da nova geração que despontava os projetos dos edifícios para abrigar exposições e atividades correlatas no Parque do Ibirapuera. Desta vez, 0 arquiteto carioca contou com uma equipe de profissionais formada por Zenon Lotufo, Hélio Uchôa Cavalcanti, Eduardo Kneese de M ello, Gauss Estelita e Carlos Lemos.

O projeto final após várias modificações compreenderia os pavilhões dedicados à Agricultura, às Indústrias, às Nações, aos Estados e às Artes, todos conectados por uma longa e sinuosa marquise de concreto.

\footnotetext{
${ }^{85}$ Depoimento de Carlos Lemos em 20 de setembro de 2007.
} 
São Paulo tornava-se a maior cidade brasileira abrigando o maior parque industrial superando a capital federal, Rio de Janeiro, e simbolicamente também o passado agrícola do período colonial. Era a locomotiva do Brasil, rumo a um futuro próspero e veloz. Assim, a arquitetura de Niemeyer e equipe respondiam a este fato.

Até então inspirado pelo passado colonial e pela geografia fluminense, 0 carioca explorava a leveza das curvas, o uso dos azulejos como revestimento tradicional da herança portuguesa e os volumes puros, bem como a precisão do sistema estrutural e da escala humana preconizada pelo mestre Le Corbusier.

No projeto do parque do Ibirapuera, Niemeyer buscou a ausência de alegorias e a austeridade das formas no sentido de atribuir um caráter novo e não mais um olhar para trás da história.

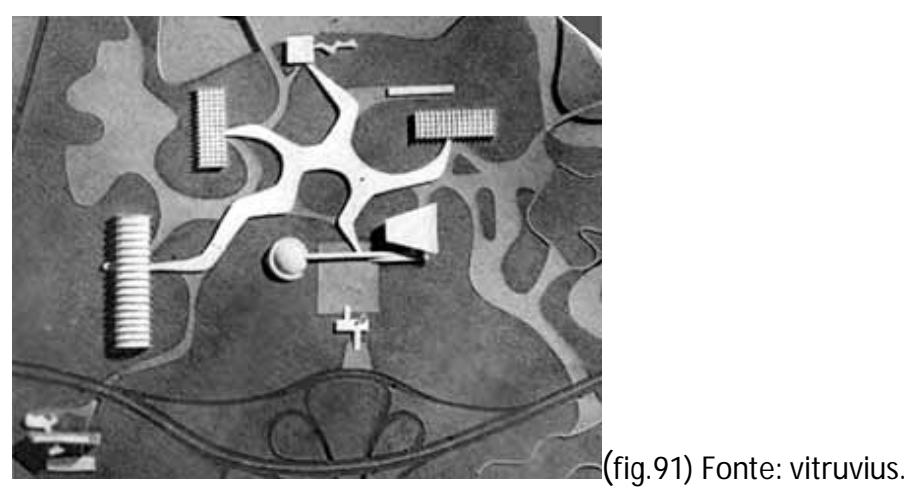

"A escolha de Niemeyer para projetar os edifícios, nome firmado nas hostes modernistas após a construção do complexo de Pampulha, praticamente inaugurou a nova linguagem arquitetônica em São Paulo, no setor das construções públicas, até então primazia do Rio de Janeiro com a construção do Ministério da Educação por Le Corbusier". ${ }^{86}$

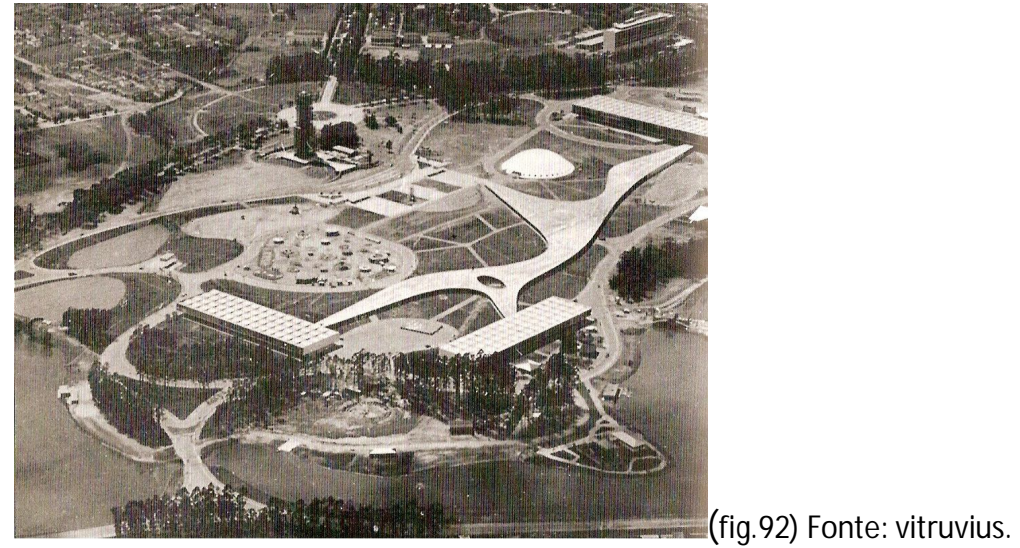

A linguagem arquitetônica procurava ser a voz da capital e as concepções de Niemeyer eram compostas de volumetria pura, clareza estrutural e escala grandiosa, fruto da busca por uma linguagem plástica de caráter nacional, como propunham arquitetos modernos.

Ora, a comissão do IV Centenário tendo a frente a figura de Ciccillo Matarazzo, criador do Museu de Arte M oderna e patrono dos grandes eventos culturais e artísticos, procurava mesmo evocar e transmitir o grau de progresso e desenvolvimento industrial e econômico do estado paulista neste seus quatro séculos de existência.

\footnotetext{
${ }^{86}$ Arruda, Maria A. do Nascimento. M etrópole e Cultura. São Paulo no meio do século do XX. Edusc, Bauru 2001, p.85.
} 
O próprio símbolo do evento - uma espiral ascendente - foi criado como uma forma helicoidal que alça vôo em direção a um futuro rápido e próspero. 0 monumento não conseguiu ser realizado por dificuldades técnicas de execução, uma vez que se tratava de uma estrutura de 17 metros em concreto armado, com uma inclinação de 60 graus, apoiada em apenas um único ponto de apoio no solo. A obra chegou a ser completada e inaugurada, mas não resistiu e caiu.
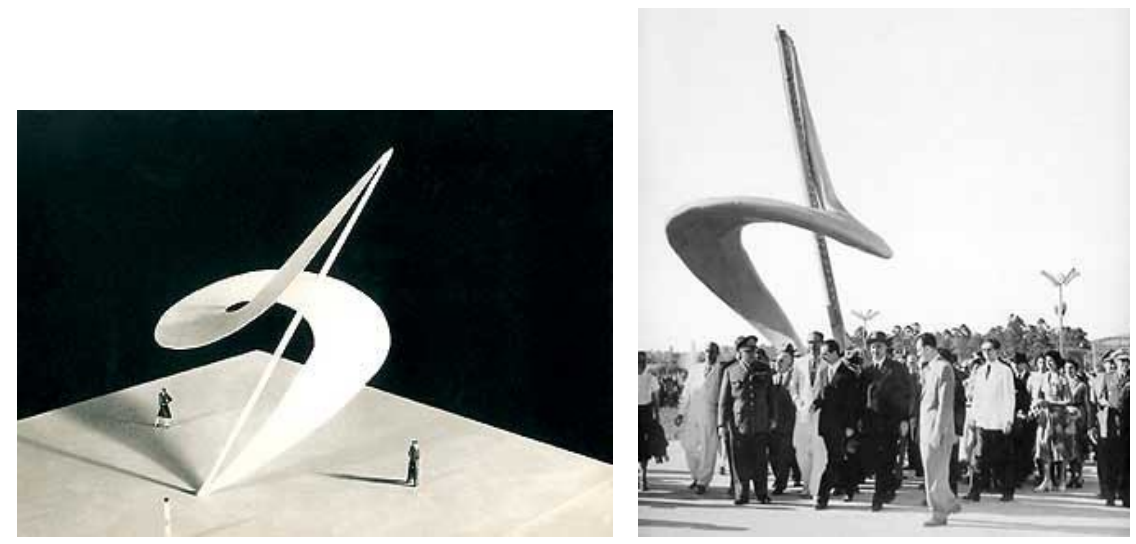

Figs. 93-94. Fonte: www.vitruvius.com.br

Mas sem dúvida, o elemento que deu maior significado ao projeto do parque Ibirapuera foi a longa e sinuosa marquise de concreto. Pois além de propor a interligação física entre os pavilhões, ela sugeria passeio em meio a natureza e a cultura, assumindo o caráter de rua, ou seja, signo fundamental da comunicação entre os lugares e a continuidade dos espaços da cidade.
"Os edifícios do Ibirapuera projetados por Niemeyer tinham centralidade no projeto de urbanização do Parque, uma vez que este se subordinava ao conjunto das construções e não o contrário, tornando a concepção do espaço e da paisagem dependente das obras arquitetônicas". ${ }^{87}$

Portanto, podemos concluir que o projeto do parque Ibirapuera pretendeu unir o desejo de se construir uma imagem de São Paulo enquanto "locomotiva" da nação com a necessidade de se fortalecer a linguagem da arquitetura brasileira, atribuindo-Ihe dimensão simbólica do momento utópico e entusiasta da política nacional: um Brasil grande e moderno.

Tal experiência rica em novas referências plásticas e conceituais (por exemplo, uso de abóbadas e cúpulas de concreto armado) contribuiu de maneira marcante na produção arquitetônica de Zenon Lotufo que as assimilou e procurou aplicá-las com uma interpretação pessoal e criativa, nos projetos posteriores que elaboraria como mostramos a seguir.

\footnotetext{
${ }^{87}$ Arruda, M. A. N. Opt. Cit., pg. 85.
} 


\subsection{Demais projetos de Zenon Lotufo na década de $\mathbf{5 0}$}

Sede para Vias e Viaturas (São Paulo/SP, 1951 - Não Construído)

Projeto: Zenon Lotufo

Fonte: Arquitetura e Engenharia 16, mar-abr 51, pp-38-39.

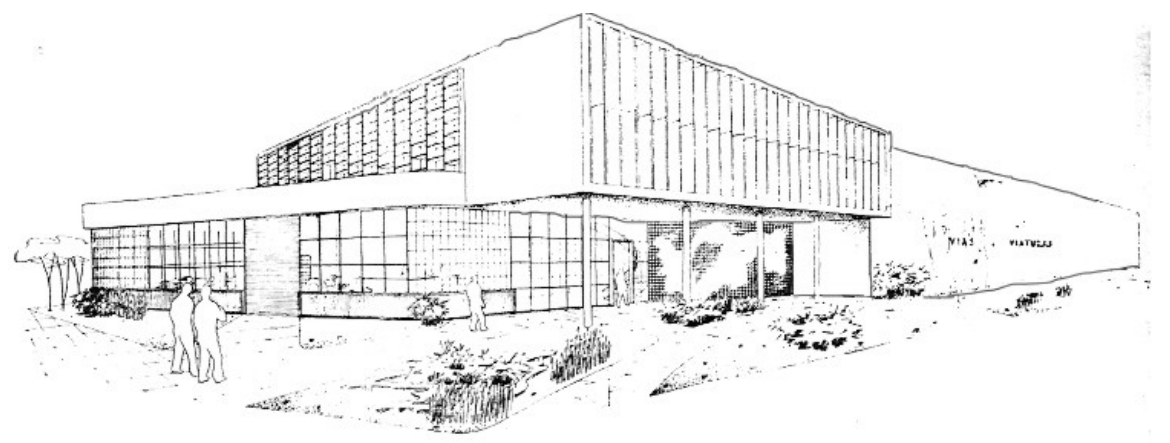

(Fig. 95)

Projeto para as novas instalações da Vias e Viaturas situado entre a Avenida do Estado e a Rua Presidente Costa Pinto. Composição volumétrica com combinações interessantes valorizando a horizontalidade do edifício com uma empena cega e uma sinalização discreta onde se localiza o gal pão de montagem. Um amplo e largo passeio ajardinado contorna a frente e onde o bloco superior se apóia sobre pilotis fica anunciada a entrada resguardada do prédio.

Programa: Térreo: Galpão - M ontagem M otores (50 funcionários) / Loja Mostruário / Almoxarifado / Controle / Escritório / Expedição /
Carpintaria / Pintura / Pátio externo; Superior: Salão para Escriturários /

Salas dos diretores / Terraço-jardim / Restaurante / Cozinha / Sanitários.

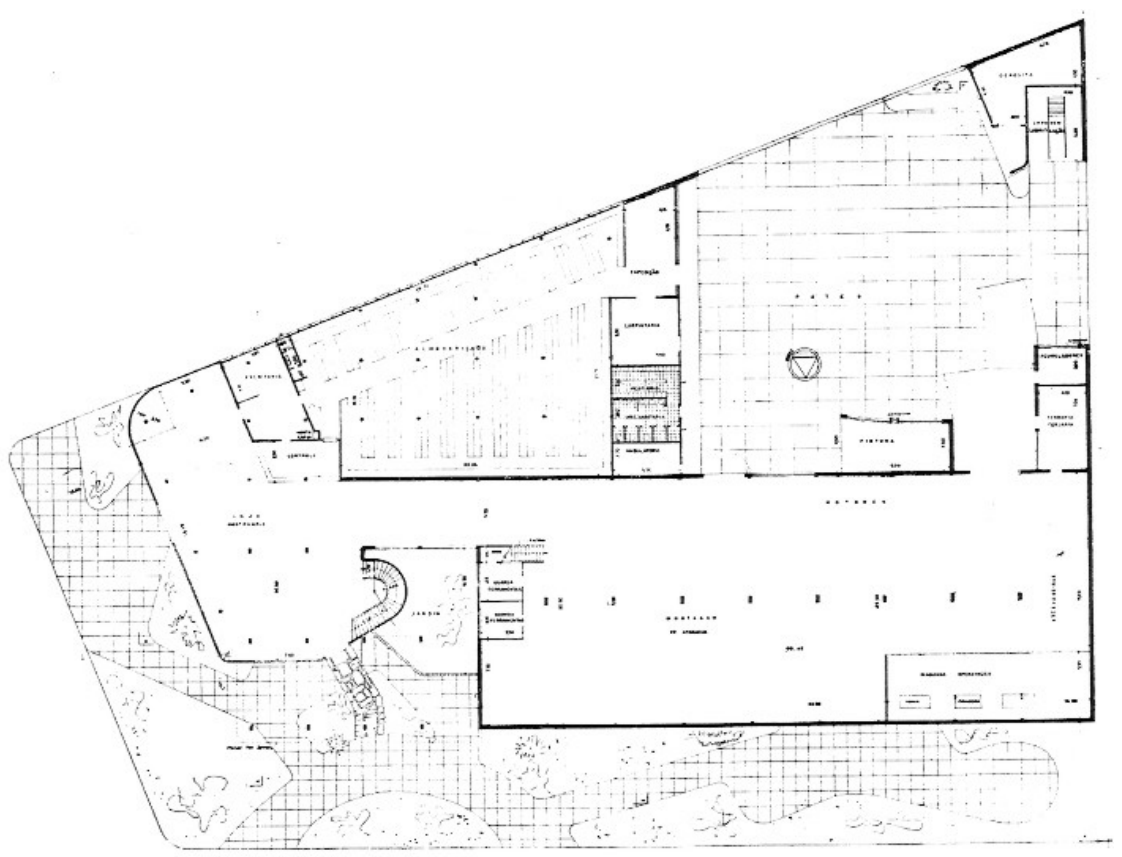

Planta - Térreo

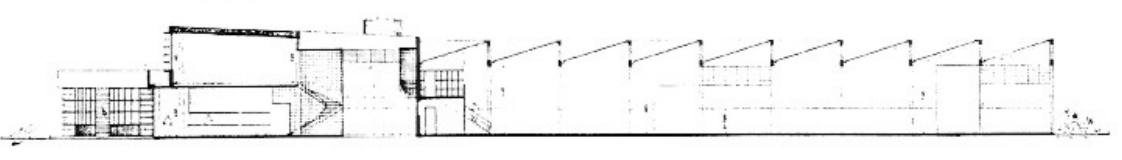

Corte Longitudinal (Figs. 96-97) 
Igreja Presbiteriana (Presidente Prudente/SP, 1951 - Não Construído)

Projeto: Zenon Lotufo

Fonte: Acrópole, jun 51, pp- 70-73.

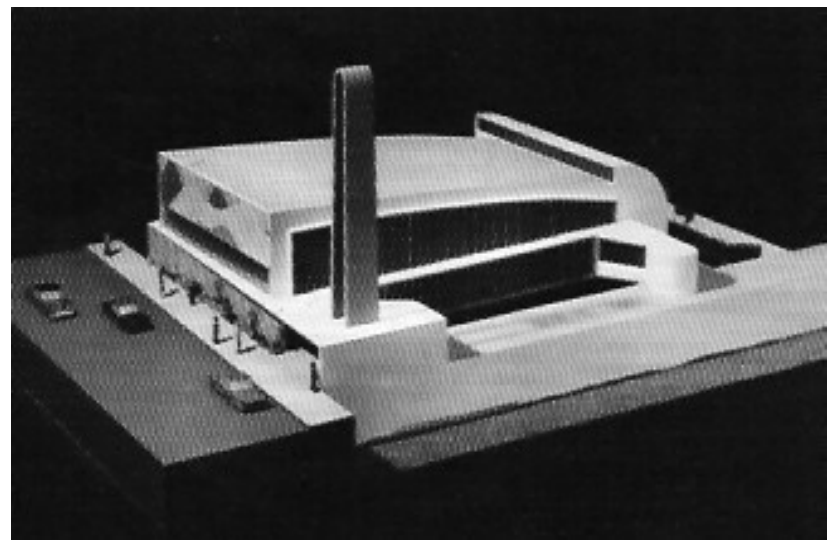

(fig. 98) Fonte: Revista AU 76.

Projeto que inaugura o uso mais recorrente das coberturas curvas de concreto armado, inspirado nas experiências e o contato com Oscar Niemeyer na elaboração do projeto para o Parque Ibirapuera.

Programa: Piso Inferior: Salão para Festas e Reuniões / Departamento Masculino / Departamento Feminino / Sanitários / Jardim de Infância / Pátio de Recreação; Piso Térreo: Hall de entrada / Rampa / Salão de culto / Púlpito / Altar / Gabinete do Pastor / Vestiário / WC; Piso Superior: Galeria-balcão / Coro e órgão.

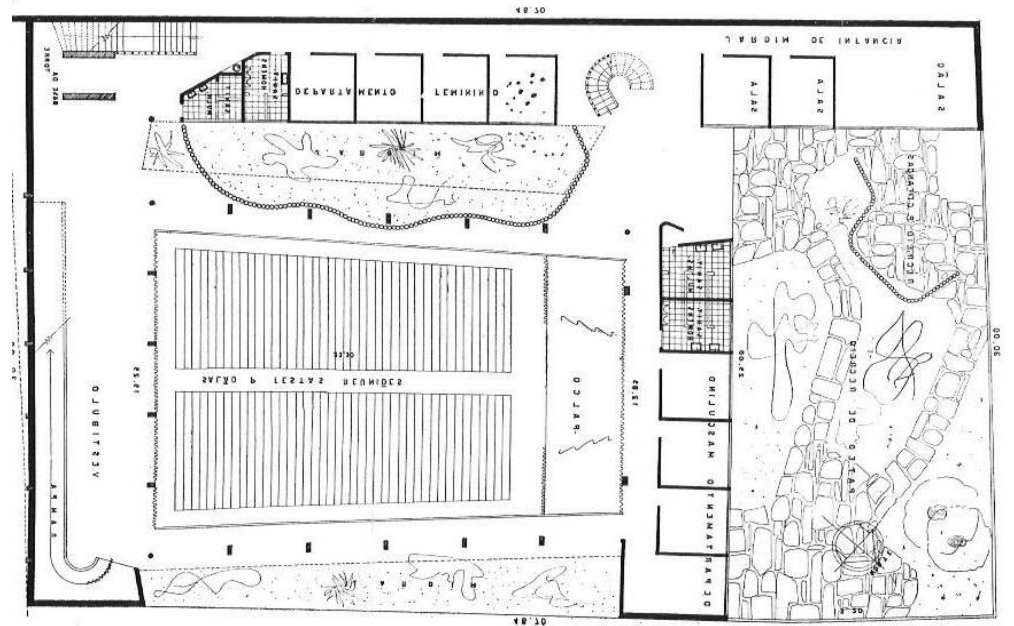

Planta - Térreo.

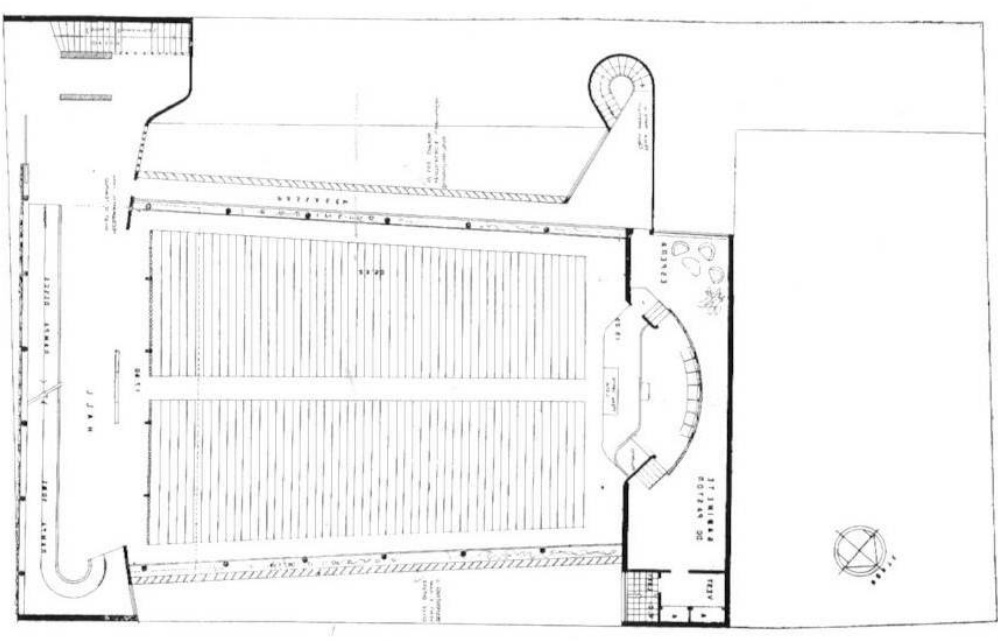

Planta - Piso Inferior. (Figs. 99-100) 


\section{Restaurante na Via Anchieta (São Paulo/SP, 1952 - Não Construído)}

Projeto: Zenon Lotufo

Fontes: Acrópole 184, jan 54, p. 187; Arquitetura e Decoração 01(53)p.7-9.

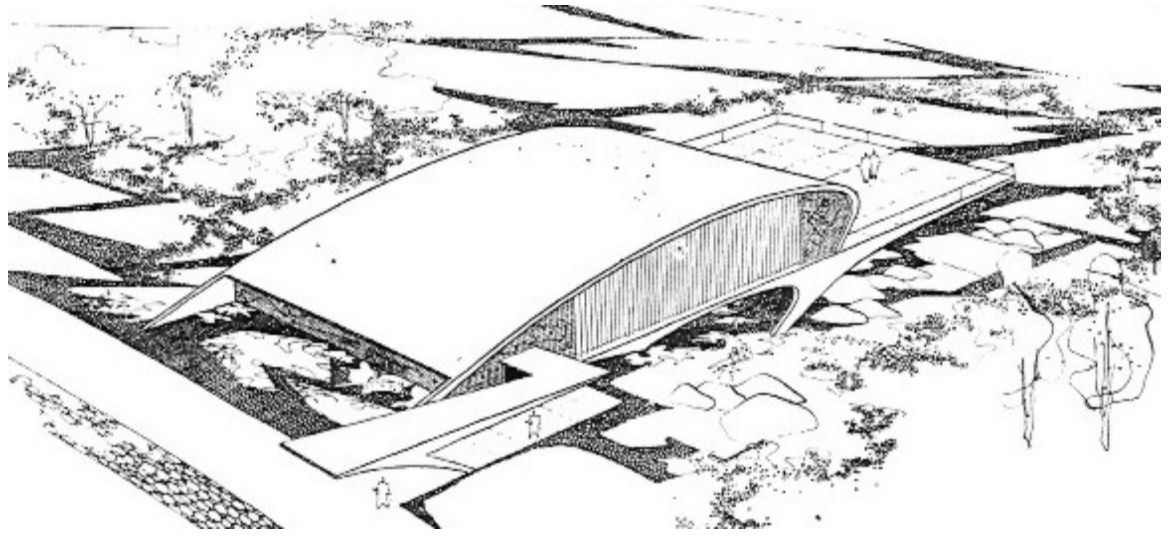

(Fig. 101) Perspectiva

Projeto aproveitava a situação do terreno e oferecia um amplo terraço para desfrute da paisagem pelos visitantes, preocupando-se também com o acesso ao local de modo a não incomodar o tráfego da Via Anchieta a partir de vias de contorno ascendentes e descendentes que cruzavam a rodovia. 0 intuito principal do D.E.R. (Departamento de Estradas de Rodagem) do Estado de São Paulo na construção do restaurante era oferecer uma atração turística a mais na descida do paulistano para o litoral.

Programa: Térreo: Marquise acesso / Salão de exposições / Bar / Sanitários / Cozinha/ Serviços / Terraço descoberto; Mezanino: Restaurante / Cozinha / Dispensa.

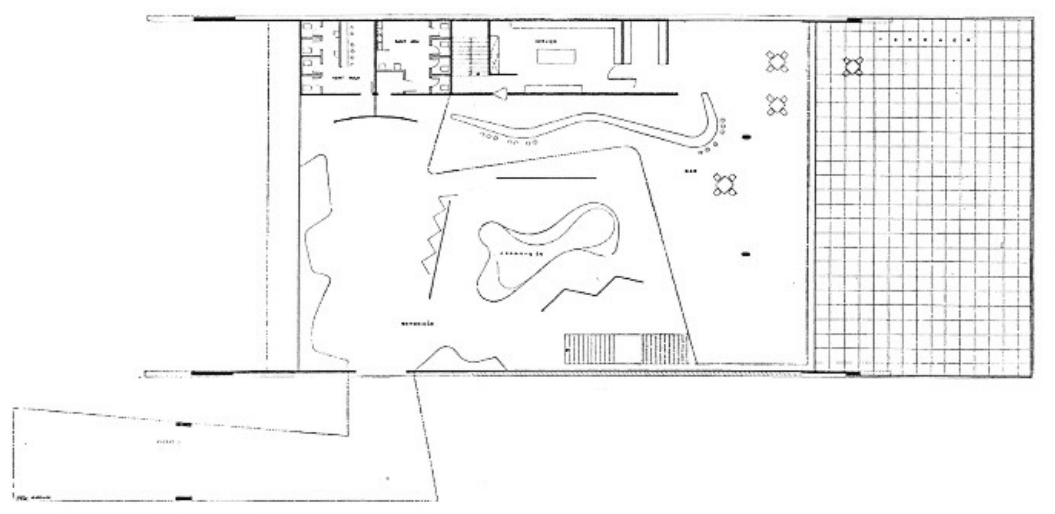

Planta - Térreo

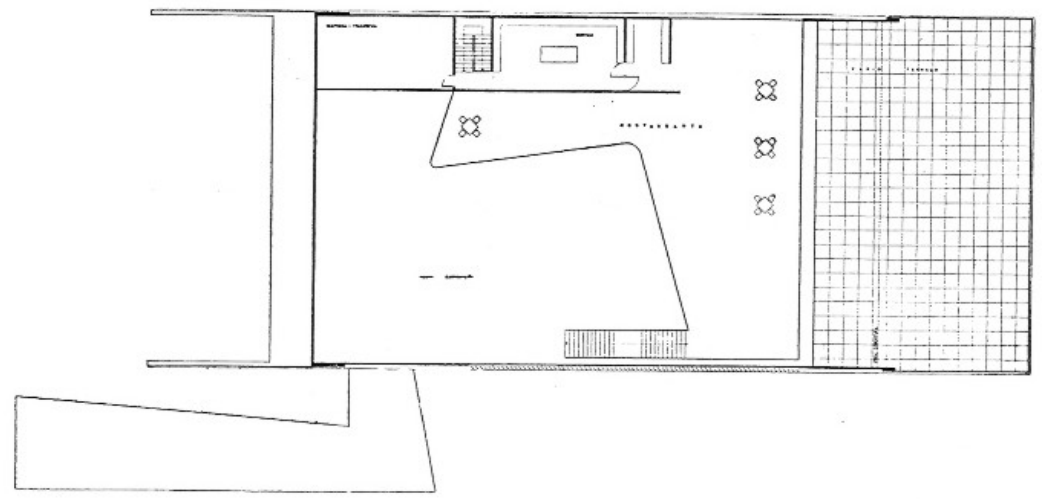

Planta - Mezanino

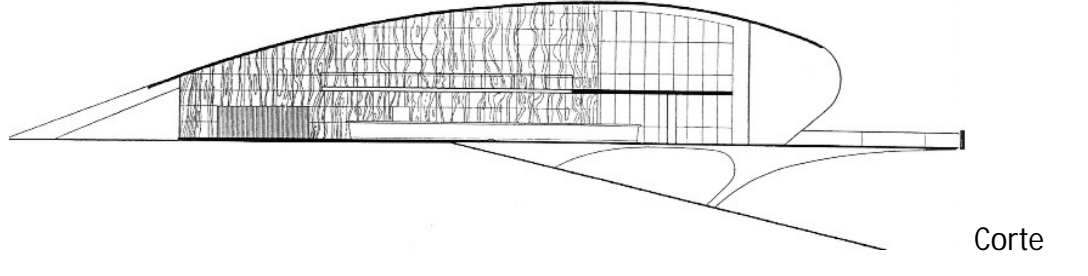

(Figs. 102-104) 
Igreja Presbiteriana de Bauru (Bauru/SP, 1953 - Não Construído)

Projeto: Zenon Lotufo

Fonte: Acrópole 180, pp- 454-456.

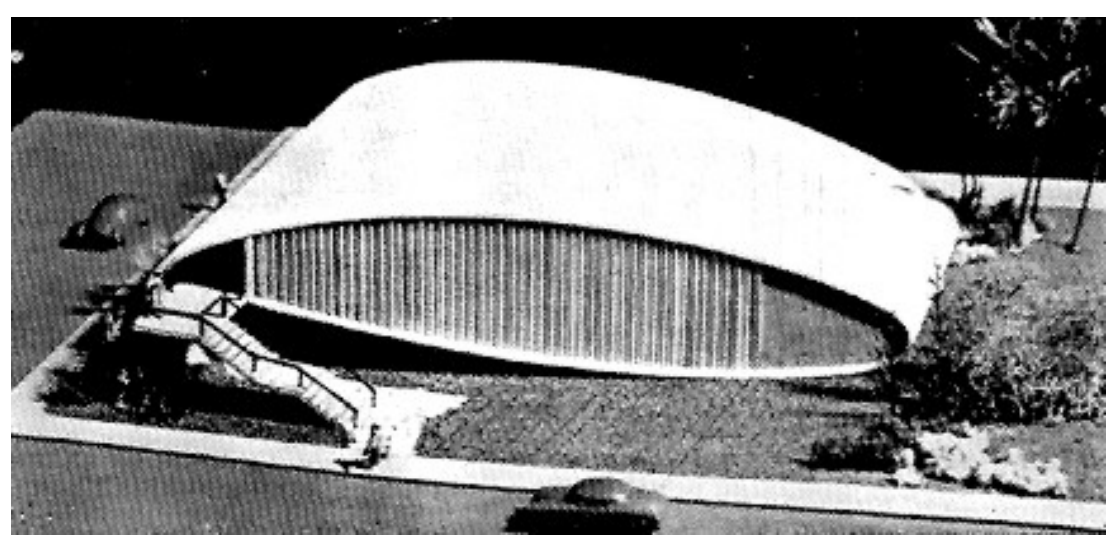

(Fig.105) Foto maquete.

Projeto realizado pelo arquiteto para templo de igreja cristã presbiteriana na cidade de Bauru que contaria com uma casca de concreto como cobertura única e iluminada lateralmente por aberturas protegidas por brises verticais. A planta assumia uma forma cônica em "V" que convergia para 0 altar, tendo na parte superior o salão da assembléia e no piso superior sanitários, depósito e acesso ao coro. 0 acesso da rua dava-se por uma escada externa que alcançava uma galeria-corredor. E a platéia descia progressivamente de modo a possibilitar a visão de todos em direção ao púlpito.

Programa: Superior: Escada de acesso / Galeria / Assembléia / Púlpito / Escritório; Inferior: Sanitários - masculino e feminino / Depósito / Coro.

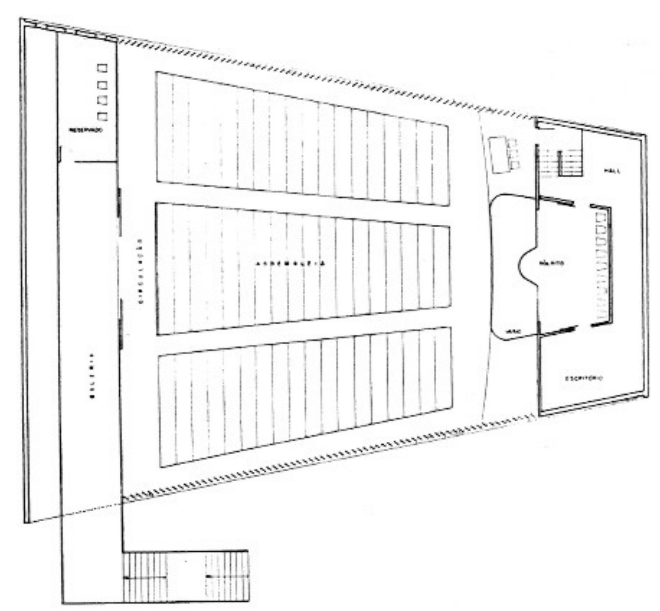

Planta Superior

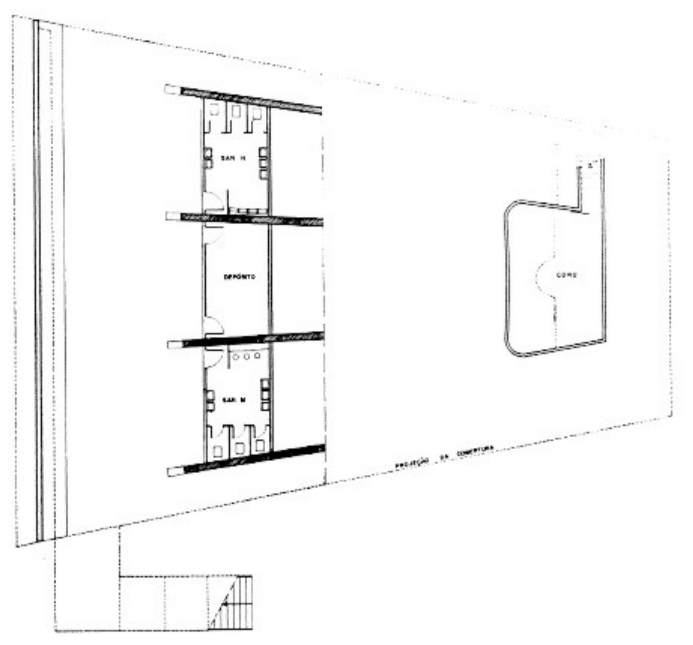

Planta Inferior

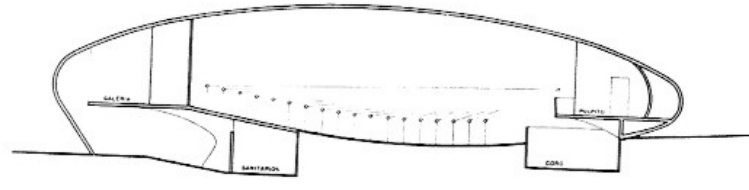

Corte (Figs.106-108) 
Paço Municipal de Bauru (Bauru/SP, 1953 - Construído parcialmente) Projeto: Zenon Lotufo

Fontes: Acrópole 186, mar 54, pp. 253-257; Arquitetura e Decoração n.06, ago 54, pp-2-5.

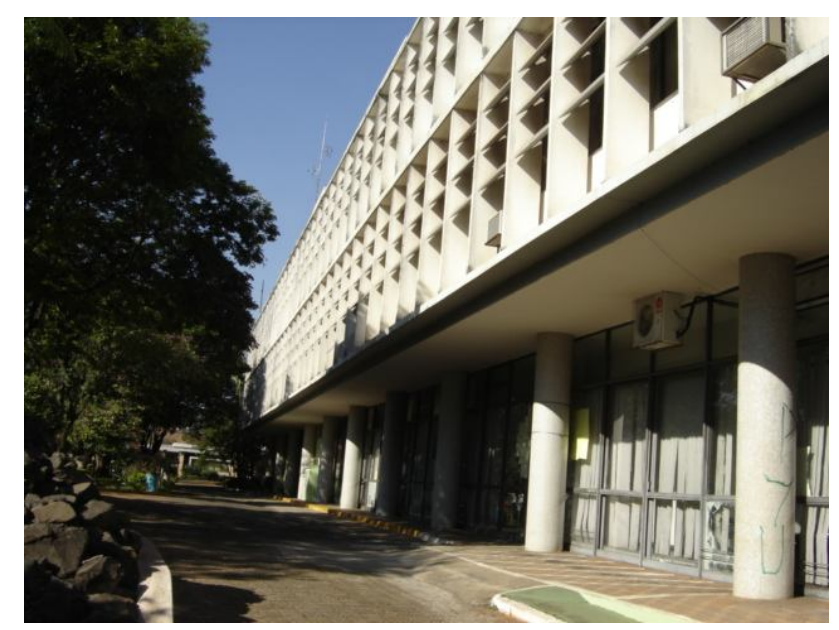

(fig. 109) Fonte: EM F.

O projeto original compunha-se de três edifícios: o Paço, a Câmara e a Sala de Sessões, todos integrados por uma grande marquise de desenho orgânico. No entanto, apenas o prédio do Paço Municipal foi construído. A ocupação do terreno levou em conta a melhor orientação, no sentido norte-sul, em relação ao trajeto do sol e a topografia do local, sendo que a face norte foi protegida com brises horizontais. Estrutura independente de concreto armado distribuída em módulos por 11 pilotis distantes 6,50 $\mathrm{m}$ em fileiras de três.
Programa: Paço Municipal: Térreo - Estacionamento prefeito / Portaria / Hall de entrada / Salão atendimento público / Sanitários Primeiro e segundo pavimentos - Andar tipo (salas administrativas). Câmara: Acesso vereadores / Copa / Sala comissões / Secretaria / Sanitários. Sala de sessões: Acesso público / Acesso vereadores / Sessões.
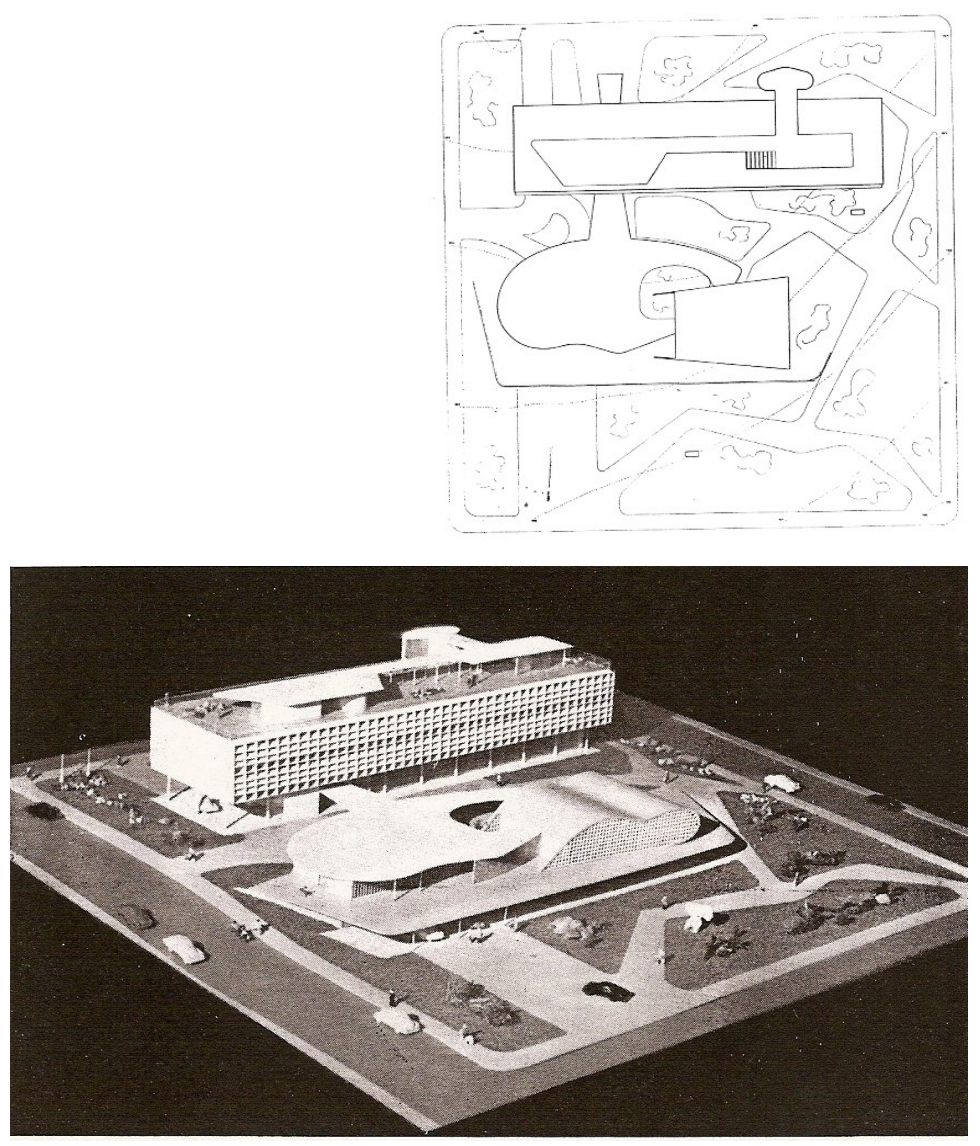

(Figs. 110-111) Implantação e foto maquete. 


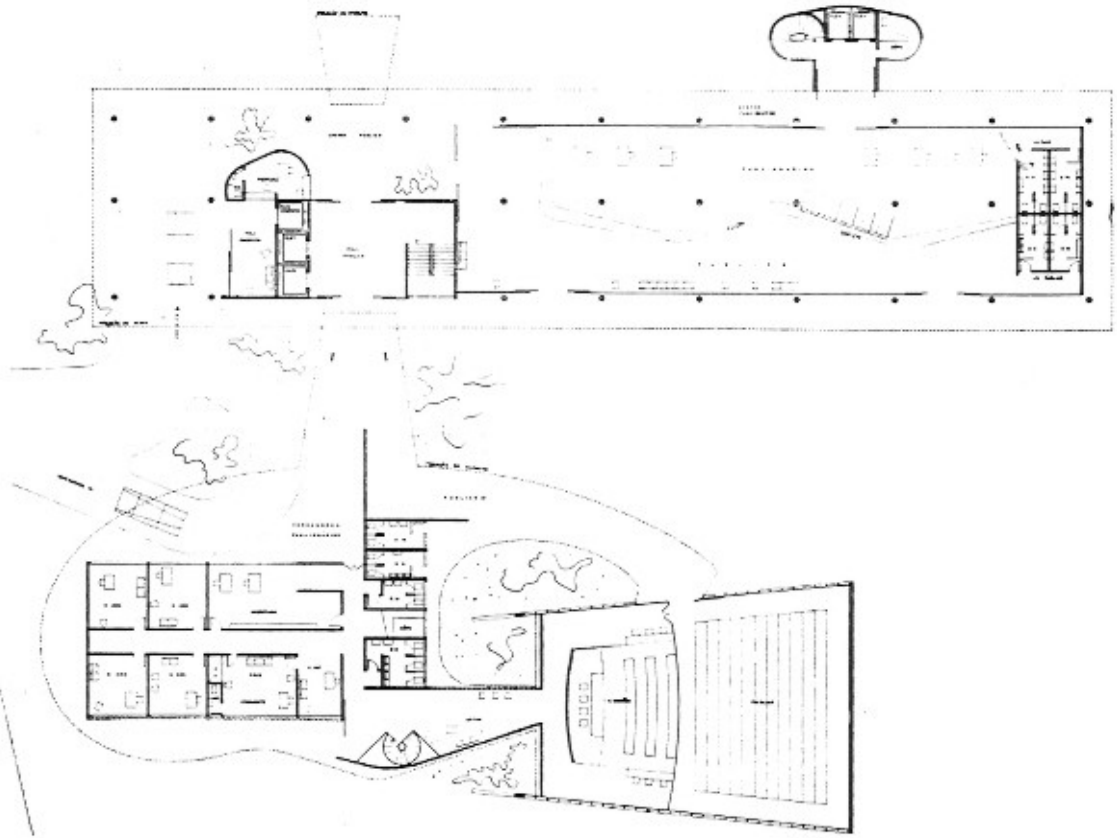

Planta Térreo - Paço / Câmara / Sala de Sessões

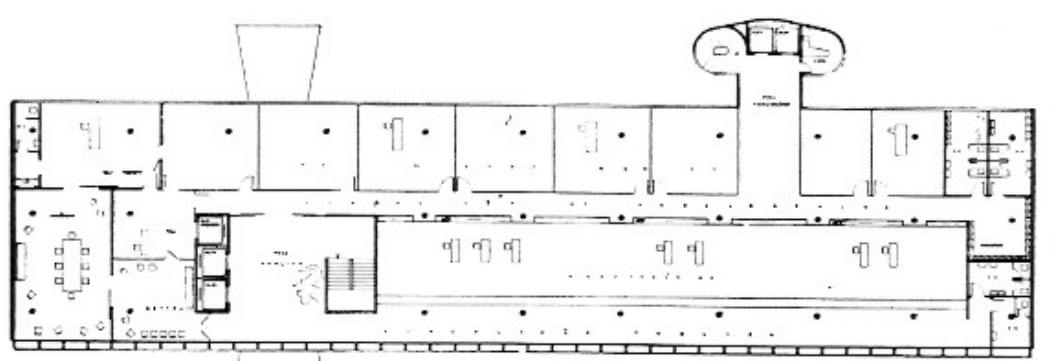

Planta $1^{\circ}$. e $2^{\circ}$. Pavimentos - Paço M unicipal (Figs. 112-113).
Paço Municipal (S. Caetano do Sul / SP, 1953-57 - Construído)

Projeto: Zenon Lotufo

Fonte: revista Raízes, dez 2002, pp. 45- 51.

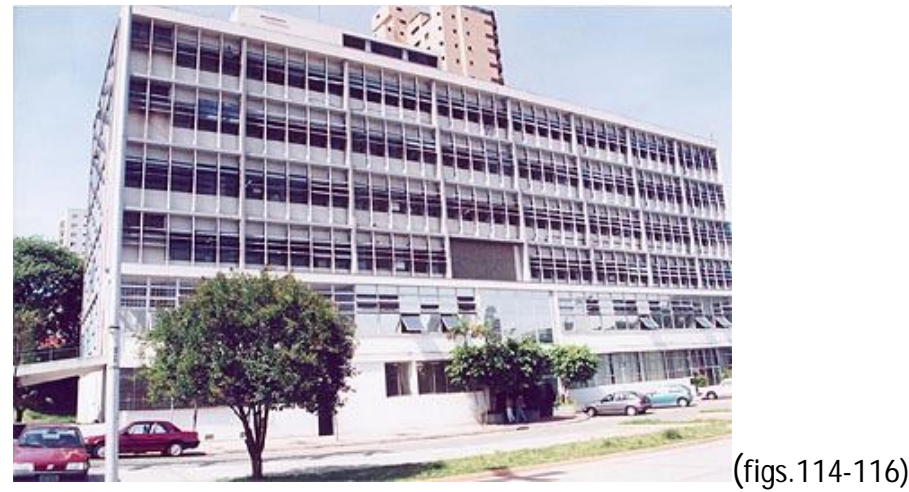

Os governantes na época almejavam um edifício com expressões modernas e imponentes a ser construído na parte central da cidade em meio a uma praça cívica onde se realizariam desfiles e eventos. Zenon Lotufo foi contratado para esta tarefa, no entanto, como aconteceu no município de Bauru, apenas o prédio do Paço M unicipal acabou sendo realizado. Os elementos compositivos da fachada são marcantes como as janelas moduladas e os brises solares horizontais.

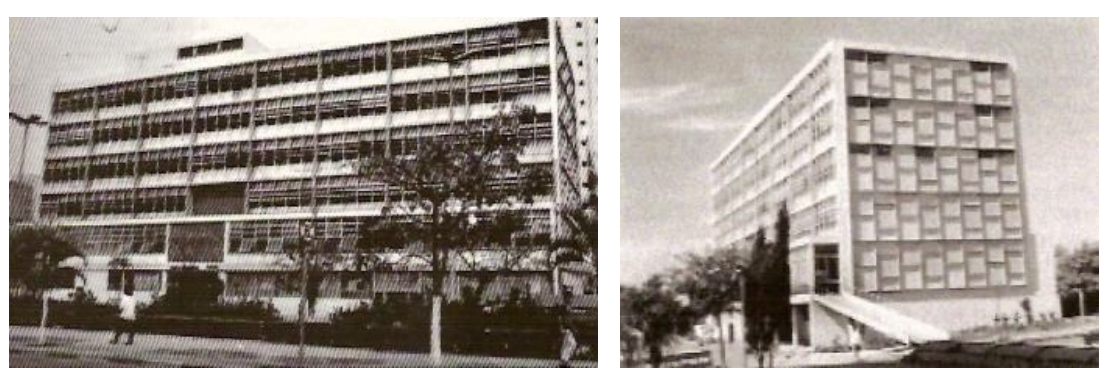


Fábrica de Fertilizantes da Petrobrás (Cubatão/SP, 1954-57- Construído) Projeto: Zenon Lotufo / M anoel Machado / Adolfo Morales / Slioma Selter. (Construção: Escrit. de Construções e Eng. Ecel Ltda).

Fonte: Acrópole 195, ago 54; Acrópole 226, ago 57, pp- 384-386; Habitat n.20, jan 55, pp. 8-10.

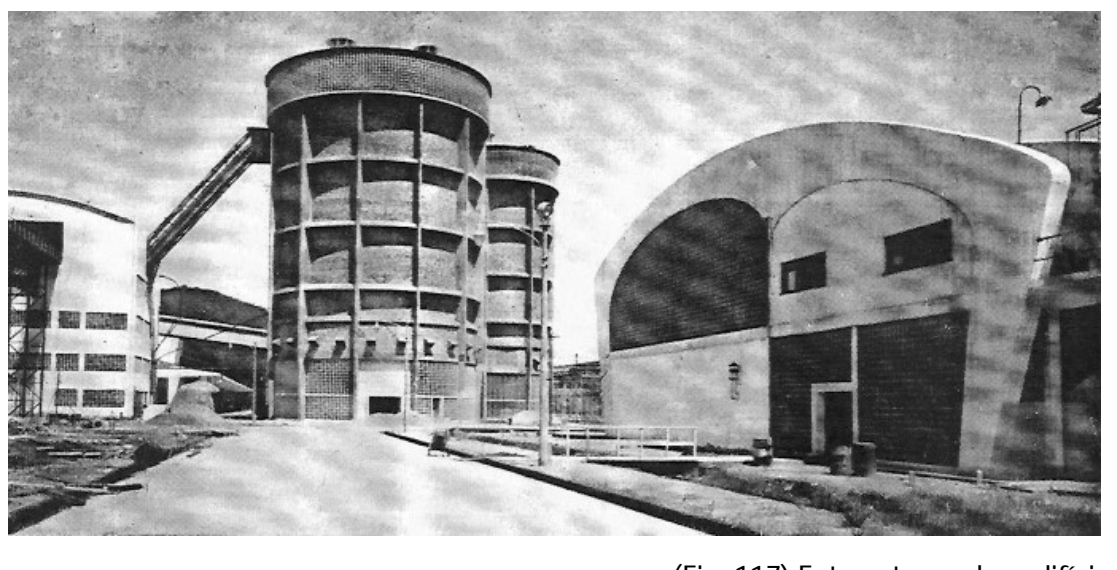

(Fig. 117) Foto externa dos edifícios.

Fábrica construída em área situada às margens do rio Cubatão destinada ao aproveitamento dos resíduos do petróleo, transformando-os em fertilizantes para produção agrícola. Todos os edifícios foram construídos em concreto armado, pensados em blocos separados, de modo a não comprometer a segurança no caso de eventuais problemas como explosões, por exemplo. Obviamente, os critérios de segregação programática foram levados em consideração de maneira a ficarem próximos os blocos destinados à administração, almoxarifado, garagem e restaurante, separados da parte industrial propriamente dita.
Programa: Entrada / Garagem / Fábrica de amônia / Almoxarifado / Vestiários / Restaurante

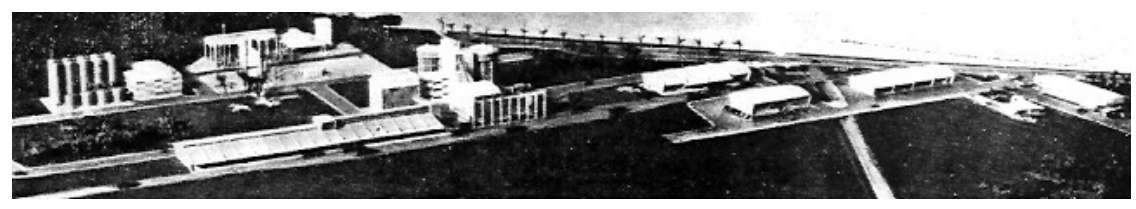

Foto geral do conjunto

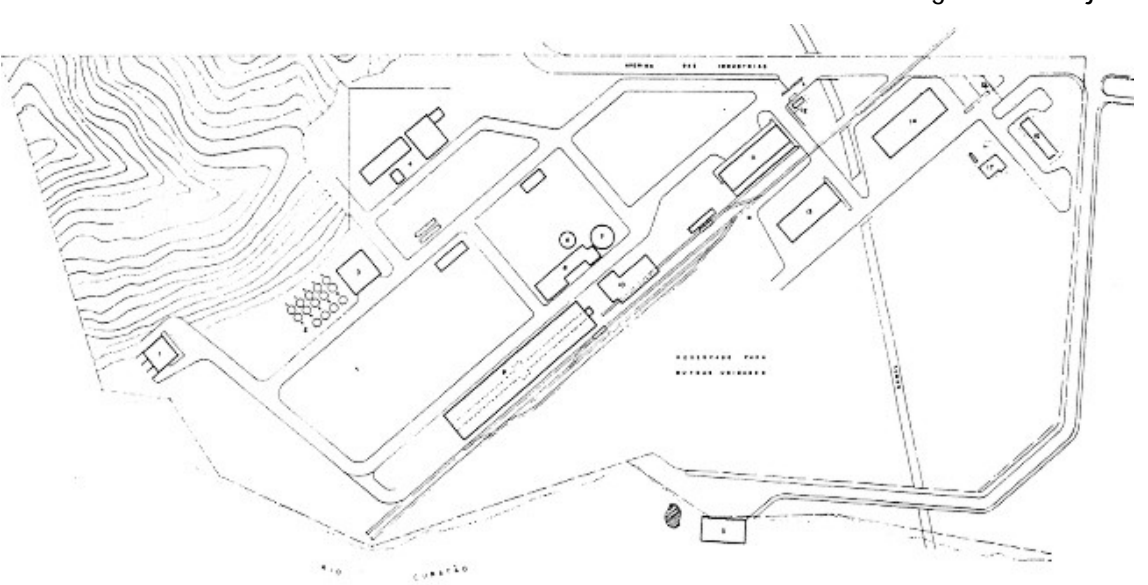

Implantação

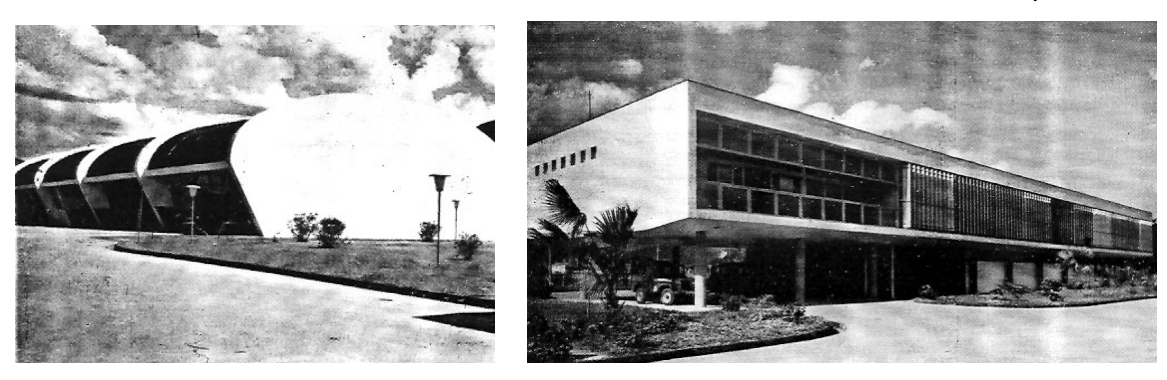

Fotos Garagem e Prédio da Administração (figs. 118-121) 
Botucatu Tênis Clube (Botucatu/SP, 1956 - Construído)

Projeto: Zenon Lotufo

Fonte: M ódulo 4, mar 56, pp- 54-55.

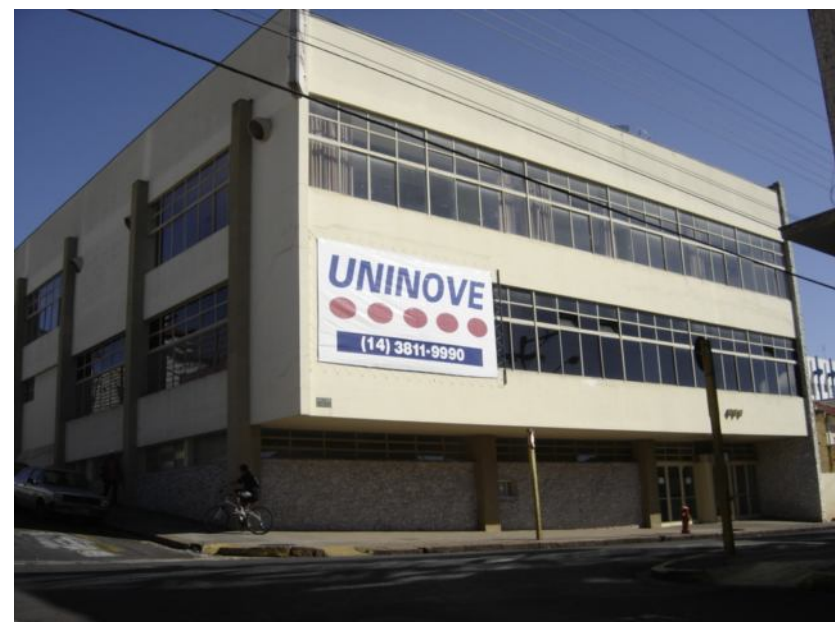

(fig. 122) Fonte externa. Fonte: EMF.

Sede social de clube esportivo situado no município de Botucatu, interior de São Paulo. A volumetria racional e econômica ocupava toda a extensão do lote tendo um dos acessos de público localizado na esquina e o outro na lateral do prédio. As circulações do edifício bem como os blocos de sanitários situavam-se na parte do fundo de maneira concentrada, otimizando as descidas de hidráulica.

Programa: Térreo: Entrada / Portaria / Salão de jogos / Escritório / Bar / Copa / Estar / Sanitários; $2^{\circ}$. Pavimento: $2^{\mathrm{a}}$. Entrada / Portaria / Secretaria / Salas de jogos / Estar; $3^{\circ}$. Pavimento: Salão de Baile / Palco para orquestra / Bar / Copa / Terraço / Sala dos músicos / Chapelaria /

Sanitários; $\mathbf{4}^{\circ}$. Pavimento: M ezanino / Terraço.

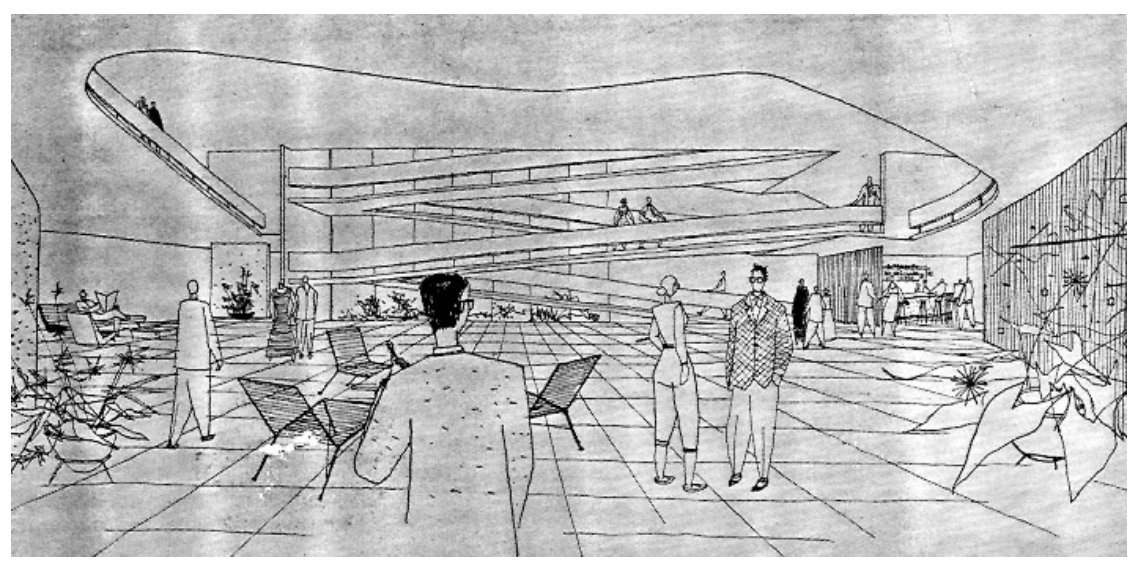

Perspectiva interna

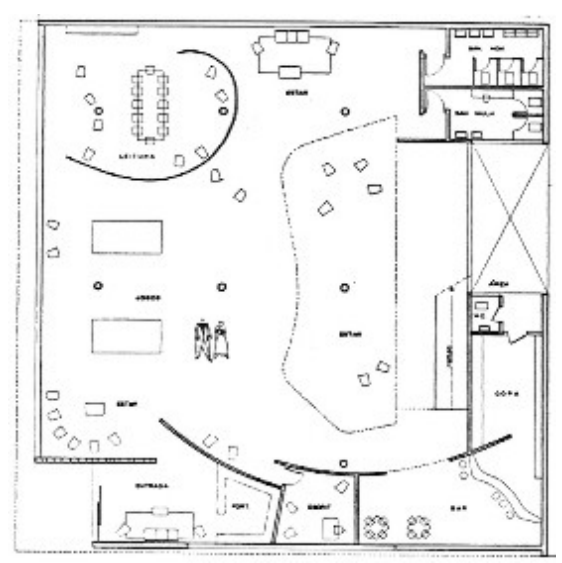

Planta Térreo

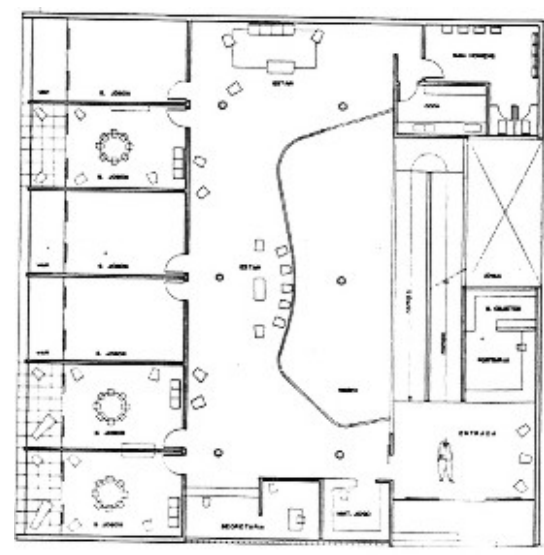

Planta $2^{\circ}$. Pavimento 


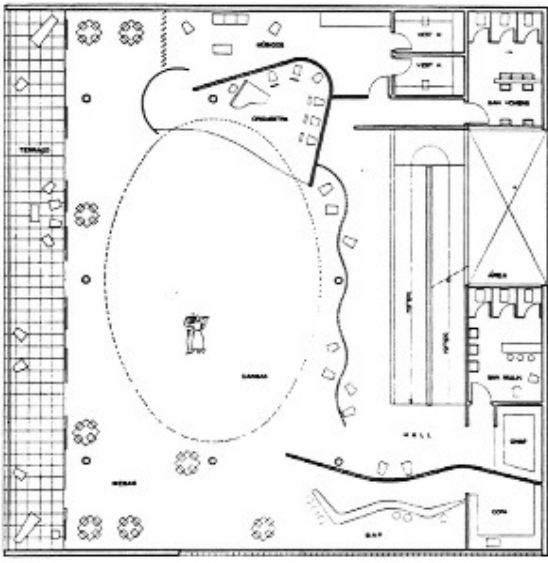

Planta $3^{\circ}$. Pavimento

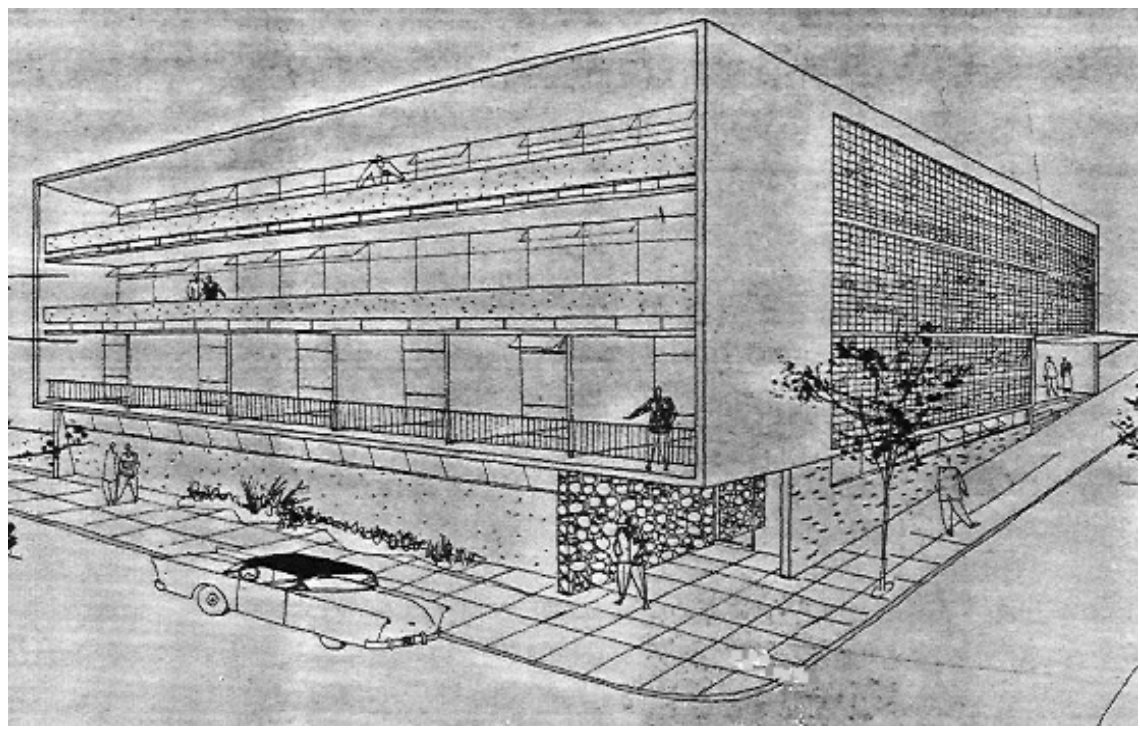

Perspectiva externa (figs. 123-128)

\section{Igreja Presbiteriana (Jandira/SP, 1957 - Não Construído)}

Projeto: Zenon Lotufo

Fonte: Revista Acrópole 223, maio 57, p. 252-253.

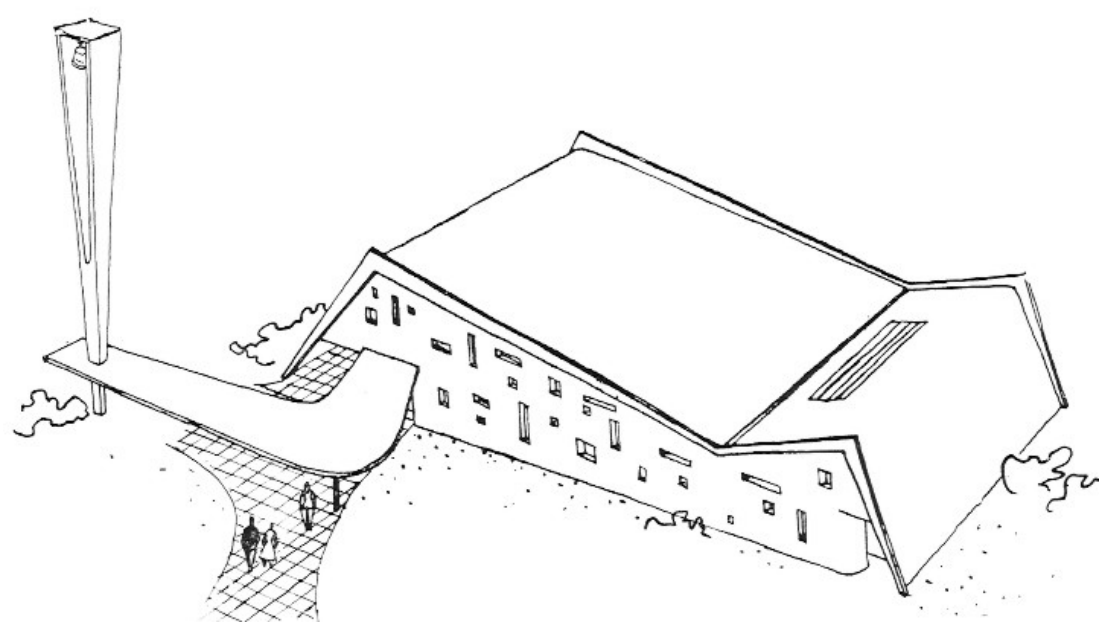

Perspectiva

Contando com uma área de construção de 270 m2 (sendo 22,50 m de comprimento por 12,00 $\mathrm{m}$ de largura) este projeto de pequena igreja situar-se-ia no município de Jandira, interior do Estado de São Paulo. As referências plástico-formais parecem óbvias quando observamos o desenho da fachada com suas pequenas e variadas aberturas lembrando o projeto de Le Corbusier para a capela Ronchamp. Bem como o conjunto formado pela marquise sinuosa e o campanário, fazendo menção a capela de São Francisco de Assis na lagoa da Pampulha, de Oscar Niemeyer.

Programa: Jardim / Entrada / Público / Altar / Balcão. 


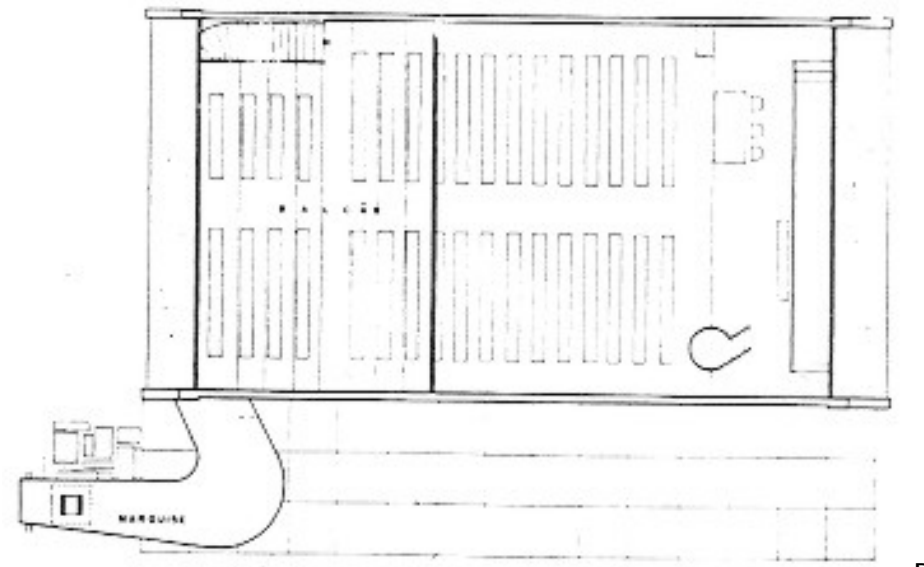

Planta - Superior

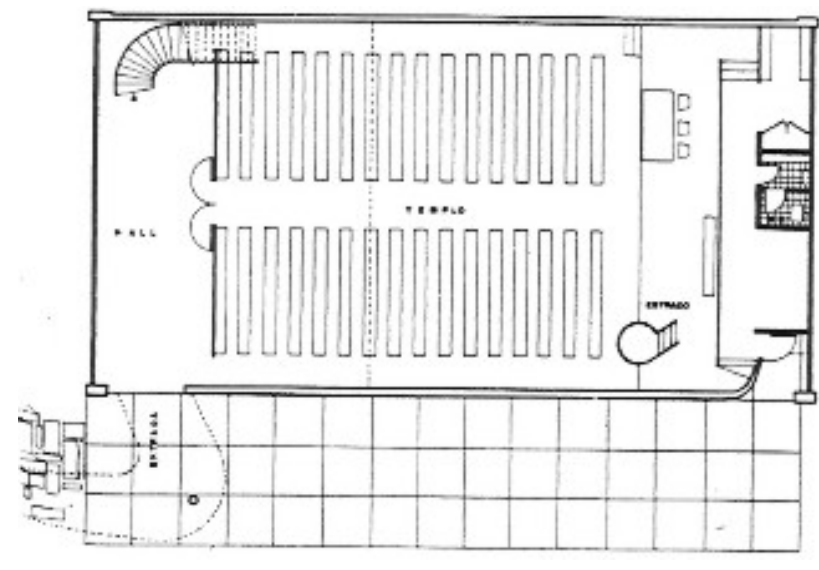

Planta - Térreo

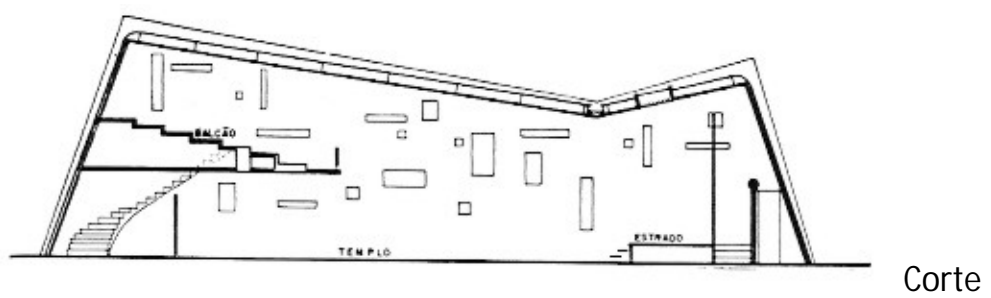

(Figs. 129-132)

\section{Edifício Arco Iris (Santos/SP, 1957 - Construído)}

Projeto: Zenon Lotufo (Fonte: Acrópole 228, out 57, pp- 54-55)

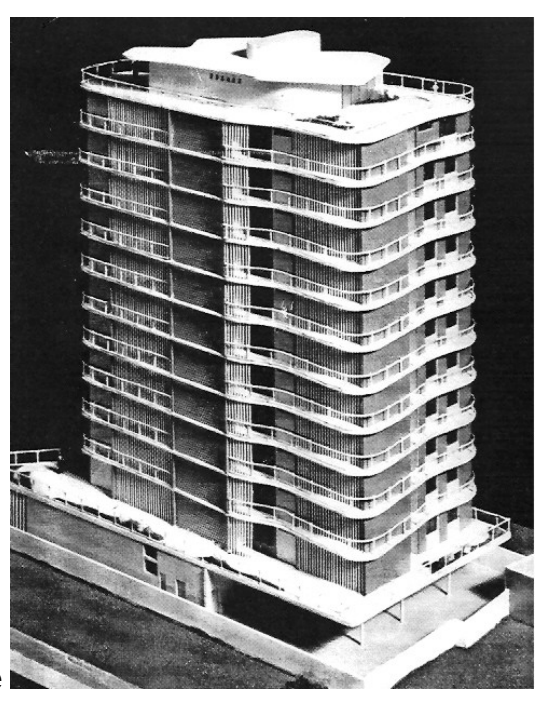

Edifício de apartamentos que se utiliza de desenhos curvos e sinuosos nos terraços para compor sua forma. A circulação vertical está definida por uma caixa de escada circular e 2 elevadores que alcançam um amplo hall aberto de distribuição para os apartamentos. Interessante notar a diferença de tipologia dos apartamentos no andar-tipo, com 3 tamanhos diferentes, sendo o da esquerda maior.

Programa: Térreo: Lojas comerciais / Garagem estacionamento; Andar Tipo: Apartamento de 2 ou 3 dormitórios / Sala / Cozinha / Quarto de empregada / WC / Terraço; Cobertura: Terraço / Salões de festa / Biblioteca / Terraço-jardim 

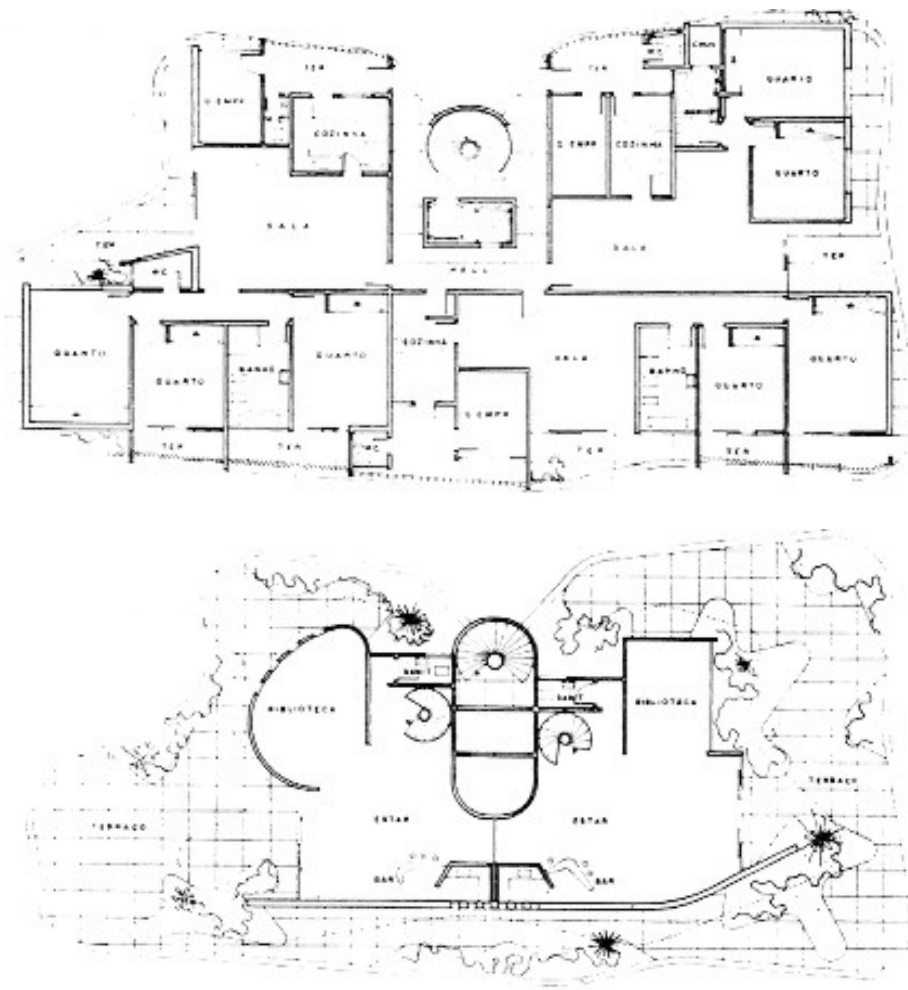

Plantas do Andar Tipo e Cobertura (Figs. 134-135)

Assim, destacamos os principais projetos realizados por Zenon Lotufo nesta fase de afirmação moderna, caracterizada por uma maior liberdade plástica nas formas e composições arquitetônicas, influenciada pelo contato direto com os arquitetos cariocas (formados pela Escola de Belas Artes) Oscar Niemeyer, Abelardo de Souza e Hélio Duarte, principalmente.

\subsection{Ensino na FAU-USP e o desastroso Concurso de Cátedra}

"A Faculdade de Arquitetura e Urbanismo da Universidade de São Paulo foi fundada em 1948 e se originou do antigo curso de engenheiroarquiteto da Escola Politécnica da mesma Universidade. Seu fundador e primeiro diretor foi o Professor Luiz Ignácio de Anhaia M ello, responsável

pela formação urbanística no antigo curso e principal organizador de novos conteúdos específicos naquele que se formava. Em seus primeiros anos, o curso da FAU combinava as disciplinas técnicas originais do antigo modelo, praticamente inalteradas, com elementos do currículo padrão da Escola Nacional de Belas Artes, organizados em disciplinas como plástica, modelagem, arquitetura de interiores, grandes e pequenas composições. Essa combinação envolvia uma grande assimetria programática e didática entre conteúdos, uma vez que - como destacava o Arq. Carlos M ilan - "as cadeiras de formação técnica eram habitualmente regidas por engenheiros, enquanto as chamadas cadeiras artísticas eram dadas por artistas plásticos, (...) lecionadas de formas muito semelhantes, senão idênticas, às adotadas para a formação de engenheiros e de artistas plásticos". ${ }^{88}$

\footnotetext{
${ }^{88}$ Trecho extraído de documento eletrônico situado na página http://www.usp.br/fau/fau/histórico.
} 
Passamos a analisar a relação entre Zenon Lotufo e a Faculdade de Arquitetura e Urbanismo da Universidade de São Paulo no âmbito de sua atividade didática e acadêmica.

Único aluno do curso de engenheiro-arquiteto de 33 a 36, da Escola Politécnica quando se formou Zenon Lotufo sempre admirara e se influenciara pelos ensinamentos e a eloqüência do professor catedrático Luiz Ignácio de Anhaia M ello (1891-1974). Tanto que iniciaria sua experiência didática junto à Universidade de São Paulo, a partir de 1938, como assistente adjunto de Anhaia.

Desde aquele momento, sua dedicação sempre fora de profunda atenção e respeito no contato com os alunos. Sua primeira experiência didática durou até 0 ano seguinte, quando se transferiu para a cidade de Santos no cargo de diretor da Secretaria de Obras Públicas.

Voltando em 45, colaborou com o professor Bruno Simões M agro na disciplina Noções de Arquitetura e, depois em 47, foi novamente assistente de Anhaia M ello, substituindo Vilanova Artigas que havia pedido licença para viagem de pesquisa aos Estados Unidos.

Curioso destacar que Artigas fora também aluno do curso de engenheiroarquiteto na Escola Politécnica tendo se formado um ano depois que Zenon. Além disso, fora também assistente do professor Anhaia na mesma cadeira. A proximidade física entre ambos (Artigas e Lotufo) era inevitável, no entanto não se encontrou nenhum relato de trabalho que tenham desenvolvido juntos, qualquer documento que comprovasse algum tipo de afinidade entre os mesmos. 0 que nos faz concluir que a relação entre eles não era lá muito amistosa.

\section{A criação da FAUUSP}

A necessidade de se criar, ou melhor, se diferenciar o ensino de arquitetura do ensino de engenharia se manifestava de forma acentuada em São Paulo na década de 40, por um grupo de arquitetos articulados. Um dos defensores era Carlos Alberto Cardim Filho que em entrevista datada de 1941 acreditava na criação de uma Escola Superior de Arquitetura, sem vínculos com a Politécnica nem com a Belas Artes. A primeira faculdade paulista de arquitetura acabou sendo o Instituto Mackenzie que conseguiu em dezembro de 1946 através do Conselho Nacional de Educação aprovar sua instalação, tendo seu reconhecimento por Decreto Federal de julho de 47 que passou então a chamar-se Faculdade de Arquitetura Mackenzie, tendo Cristiano Stockler das Neves como seu primeiro diretor.

No caso da Universidade de São Paulo, o procedimento jurídico-legal também já estava em andamento naquela época, tendo outro grupo orientando a remodelação do curso de engenheiro-arquiteto "nos moldes do padrão federal da Faculdade Superior de Arquitetura, ou seja, com 
direção autônoma e adaptável às necessidades atuais de uma

organização universitária". ${ }^{89}$

Novamente, se destacaria nesta ocasião a personalidade forte de Anhaia M ello como principal interventor em favor da criação da nova faculdade. A família Álvares Penteado apressou o desenlance desta história quando fez adoação da residência em estilo Art-nouveau situada no bairro de Higienópolis à Universidade de São Paulo, objetivando o acolhimento da nova escola de arquitetura.

Assim, em março de 1948, começaria a funcionar a Faculdade de

Arquitetura e Urbanismo (o enfoque para o urbanismo do curso era dado por Anhaia Mello) da Universidade de São Paulo em Decreto Federal de 21 de junho de 1948, tendo Anhaia Mello como primeiro diretor.

Portanto, naquela ocasião configuram-se os moldes das duas principais escolas de arquitetura paulistana.

No entanto, havia concepções diferentes na orientação dos estudos: uma era mais influenciada pela formação americana de Stockler das Neves, representando paradoxalmente os ideais do ensino beaux-arts francês; e outra mais humanista e culta, resultando da prática urbanística americana e aderência aos valores estéticos modernos.

\footnotetext{
${ }^{89}$ Ficher, Silvia. Os arquitetos da Poli. Ensino e profissão em São Paulo. Edusp, São Paulo, 2005, pg. 254.
}

Ou seja, a FAUUSP voltava-se mais para a manutenção de certos ideais politécnicos: o conhecimento técnico da construção, preocupação urbanística e estética racional moderna.

Em 4 de maio de 1949, Zenon Lotufo foi contratado pelo prazo de 2 anos como professor catedrático para reger a disciplina n. 16 "Composição de Arquitetura" para o 1‥ Ano do recém-criado Curso de Arquitetura e Urbanismo da Universidade de São Paulo (Lei n. 104, de 21 de junho de 1948), na vaga de João Batista Vilanova Artigas, que foi transferido para o $2^{\circ}$. Ano.

"Fui da secunda turma da FAUUSP, me formei em 53. Zenon foi meu professor no 10 ano da escola. Ele e o Hélio (Duarte) davam aulas de projeto. Era uma pessoa recatada, talvez pelo fato da religião (protestante), mas não era um professor notório que criava seguidores ou inspirava muito os alunos. Era à sua maneira, anônimo, apagado e sério. Seu riso era contido, pelo que me lembro. Não era homem de vanguarda. Artigas praticamente o desconsiderava. No entanto, prevalecia nas aulas, a arquitetura funcionalista, voltada para as funções do espaço, circulação, orientação, implantação etc." 90

Nascido em Botucatu em 1932, 0 arquiteto Eugênio H. Monteferrante formou-se na FAUUSP, cursou de 52 a 57 e foi aluno de Zenon Lotufo, no primeiro ano de curso. Em relato pessoal, confessou:

\footnotetext{
${ }^{90}$ Depoimento de Jon M aitrejean em 30 de outubro de 2007.
} 
"Aprendi com o professor Zenon, a verdadeira noção de circulação na construção. Além desse aspecto, de suma importância no projeto, Zenon destacava ainda: a autenticidade dos materiais, a planta bem elaborada, o que já definia as fachadas do edifício,a implantação correta segundo a melhor orientação, insolação, ventos dominantes e topografia, a hierarquia dos ambientes, hall de distribuição, estrutura, fluxograma e programa." ${ }^{91}$

\section{Concurso de Cátedra}

A situação de renovação contratual de Zenon Lotufo como professor da FAUUSP perduraria até 1956, portanto 7 anos, quando se anunciou, mediante publicação no Diário Oficial da União, o Concurso para provimento de cargo de Professor Catedrático da Cadeira n.16, agora então conhecida como "Composição de Arquitetura. Pequenas Composições I. Desenho Arquitetônico e Plástica I". Na publicação oficial regia o seguinte texto:

“De ordem do então Diretor Lysandro M eles Pereira da Silva e em cumprimento à deliberação do Egrégio Conselho Universitário funcionando como Congregação desta Universidade acha-se aberta na Secretaria desta Faculdade a inscrição para o concurso de preenchimento

${ }^{91}$ Depoimento de Eugênio Henrique Monteferrante em 16 de maio de 2007. do cargo de Professor Catedrático da Cadeira n. 16. Para a inscrição, de acordo com legislação em vigor, o candidato deve apresentar: diploma profissional, prova que é naturalizado ou brasileiro nato, certificado quitado militar, prova de sanidade física e mental e idoneidade moral, documentação de atividade profissional exercida durante o prazo mínimo de 06 anos e por fim, 100 (cem) exemplares de tese original sobre assunto de livre escolha, pertinente a matéria em concurso e cuja defesa constituirá prova obrigatória." ${ }^{92}$

Em 7 de julho de 1957, ou seja, um ano e meio depois da primeira publicação, o então vice-diretor em exercício Pedro Bento José Gravina divulgaria publicamente através do Diário Oficial da União, as datas das provas do concurso que se daria em 9 de agosto daquele mesmo ano, com início marcado para às 10 horas da manhã.

Bem como a Comissão Julgadora que seria constituída pelos seguintes professores: Dr. Demétrio Ribeiro, da Faculdade de Arquitetura da Universidade do Rio Grande do Sul; Dr. Sylvio de Vasconcelos, da Faculdade de Arquitetura da Universidade de M inas Gerais; Dr. José Benedicto de Camargo, da Escola Superior de Agricultura “Luiz de Queiroz" da Universidade de São Paulo; Dr. Lourival Gomes Machado, da

\footnotetext{
${ }^{92}$ Extraído de reprodução do recorte original do jornal Diário Oficial da União em 31 de janeiro de 1956.
} 
Faculdade de Filosofia, Ciências e Letras da Universidade de São Paulo e Dr. Diógenes Rebouças, da Escola de Belas Artes da Universidade da Bahia.

A seguir, relatamos um breve resumo das principais atividades realizadas pelos membros da banca examinadora, a fim de conhecer melhor 0 mérito e a qualidade dos mesmos.

\section{Demétrio Ribeiro}

Demétrio Ribeiro nasceu em Porto Alegre em 1916 e se formou na Faculdade de Arquitetura de M ontevidéu em 1943, posteriormente ingressando na Secretaria de Obras do Estado do Rio Grande do Sul em

45. A influência de alguns professores no Uruguai durante sua formação acadêmica foi decisiva. Como no caso de Júlio Vilanajó que professava os princípios universais e permanentes da Composição.

Demétrio dizia que era necessário ter noção de composição arquitetônica ao fazer o projeto.

“Composição é noção de ordem. Alberti já escrevera sobre isto no Renascimento italiano. Como é que se projeta algo que é composto por partes distintas, mas que deve ser uma coisa só? Deve ter em mente 0 princípio da unidade, onde não se pode retirar nada sem se notar a falta".

Foi um dos fundadores da Faculdade de Arquitetura da Universidade Federal do Rio Grande do Sul, em 52, lecionando por vários anos no curso. De 46 a 51, exerceu a cátedra no Instituto de Belas Artes na disciplina Composições de Arquitetura. E posteriormente com a fundação do curso de Arquitetura, permaneceu como titular em Composições de Arquitetura, de 52 a 64.

Em 1954, por ocasião do IV Congresso Brasileiro de Arquitetos em São Paulo, Demétrio Ribeiro, juntamente com Enilda Ribeiro e Nelson Souza, apresentaram a tese intitulada Situação da arquitetura brasileira. ${ }^{94}$ Naquela oportunidade, os autores defendiam uma visão mais autocrítica da arquitetura moderna de modo a democratizar seus valores estéticos tendo em vista a satisfação das necessidades materiais e espirituais do povo brasileiro. Ou seja, arquitetura não deveria ser uma arte que depende do talento e da originalidade individual, mas sim o resultado de um exame atento às realidades sociais e culturais do nosso meio.

\footnotetext{
${ }^{93}$ Relato publicado Udo S. M ohr por ocasião do falecimento de Demetrio Ribeiro, em artigo eletrônico

http:// www.vitruvius.com.br/arquitextos/arq041/arq041_00.asp

${ }^{94}$ XAVIER, Alberto (org.) Depoimento de uma geração. Cosac \& Naify, São Paulo, 2003, pg. 203-207.
} 
“É necessário compreender o caráter social do processo de elaboração e fixação das formas capazes de definirem a arquitetura de uma nação e de uma época." ${ }^{95}$

Cassado pela ditadura militar em 64, Demétrio só retornaria à Faculdade em 1980, quando foi condecorado com o título de Professor Emérito. Foi autor de vários planos diretores sendo também premiado em alguns concursos públicos. Acreditava na arquitetura moderna que priorizava o bem-estar e o conforto estético obtidos com o mínimo de recursos.

Faleceu em outubro de 2003.

\section{Sylvio de Vasconcellos}

Nascido em Belo Horizonte em 1916, Sylvio de Vasconcellos formou-se na Escola de Arquitetura da UFM G em 44, onde lecionou de 48 a 69 e foi diretor em 63-64. Dedicou-se atentamente à pesquisa e catalogação da arte e da arquitetura colonial e barroca mineira, especialmente a obra de Antonio Francisco Lisboa, o Aleijadinho. Tal fato gerou inúmeras publicações e artigos sobre preservação do patrimônio histórico e arquitetônico dedicando-se a isso ao longo dos trinta anos (39-69) em que esteve à frente do IPHAN-MG (Instituto do Patrimônio Artístico Nacional de Minas Gerais).

\footnotetext{
95 Idem, pg. 205.
}

Foi professor na Universidade do Chile em 1966 e de Brasília (UnB) em 68. Publicou livros de destacada importância como Arquitetura no Brasil sistemas construtivos (51), Vila Rica: formação e desenvolvimento (56), Vocabulário arquitetônico (61) e Vida e obra de Antonio Francisco Lisboa, o Aleijadinho (79), entre outros.

Em 29 de junho de 1957, Sylvio de Vasconcellos publicou no jornal 0 Estado de São Paulo o artigo intitulado Crítica de arte e arquitetura ${ }^{96}$ onde questionava o papel da crítica de arte especializada em arquitetura apontando problemas e alternativas para melhorar sua eficácia.

Segundo ele, o Brasil despontava sua produção arquitetônica para os olhos do mundo, mas não gozava de um corpo técnico capaz de contestar e discutir o sucesso repentino da arquitetura moderna nacional, e muito menos de um canal receptor (leia-se: o povo) preparado para as lições a serem emitidas.

Fez crítica ao modo de ver de Mário Pedrosa, que em artigo anterior ${ }^{97}$ defendera a arte arquitetônica como solução plástica ao lado da pintura, escultura e gravura, onde o que interessaria era seu aspecto belo e deleitoso.

\footnotetext{
${ }^{96}$ XAVIER, Alberto (org.) Depoimento de uma geração. Cosac \& Naify, São Paulo, 2003, pg. 287-289.

${ }^{97}$ Mário Pedrosa, Jornal do Brasil, em 23 fev. 1957.
} 
Do outro lado, Vasconcellos defendia a idéia de que a arquitetura deveria estar integrada à vida, onde o interior importasse tanto quanto exterior; a técnica e a finalidade (uso) deveriam ser adequadas ao bem-estar material e espiritual do povo.

"Procurar a correspondência ideal entre a organização de espaço e o estilo de vida a que ele vai servir. Inclusive para que essa organização não atenda só às tendências da vida moderna, mas que influa sobre 0 status familiar e social. A arquitetura estará assim ocupando seu verdadeiro lugar na civilização contemporânea, participando ativa e efetivamente dela e não apenas ornamentando-a com monumentos isolados, ainda que de incontestável beleza". ${ }^{98}$

\section{Diógenes Rebouças}

Integrante e principal responsável pelo então EPUS (Escritório de Planejamento Urbano de Salvador), criado em 46, Diógenes Rebouças foi um dos pioneiros na introdução da arquitetura moderna na Bahia. Nasceu em 1914 e diplomado na Escola de Belas Artes da Universidade Federal da Bahia em 52 onde passou a lecionar posteriormente, sendo notável professor da futura escola de Arquitetura da UFBa. Diógenes faleceu em 1994, com 80 anos. Divulgou e empreendeu uma visão

\footnotetext{
${ }^{98}$ XAVIER, Alberto (org.) Depoimento de uma geração. Cosac \& Naify, São Paulo, 2003, pg. 289.
}

interdisciplinar da arquitetura sempre vinculada à realidade urbana. Ou seja, sua visão de urbanista prevalecia sobre a concepção arquitetônica. M ostrava-se adepto da matriz corbusiana, privilegiando o uso racional dos materiais, a economia de ornamentos e o diálogo com a tecnologia industrial.

Dentre seus principais projetos, destaques para: Avenida Contorno, Estação M arítima, Faculdade de Farmácia, Arquitetura e a Escola Politécnica da UFBa, o estádio da Fonte Nova, a estação do FerryBoat, entre outros. Em 1947, juntamente com Hélio Duarte, desenvolveu 0 projeto para a Escola Parque com a concepção programática de Anísio Teixeira.

Para Diógenes, sempre deveria existir um raciocínio maior que legitimasse a arquitetura em face de seu contexto físico, histórico, social e econômico urbano. Os valores formais e plásticos deveriam fluir espontaneamente reforçando a relação entre o "partido arquitetônico" e a geomorfologia do sítio, cuja base era a cidade, dentro de sua lógica e princípios.

“Projeto é papel pintado, se rasga e se joga fora, fazendo-se outros. Já obra, não. Se feita de modo errado, estará sempre lá, confessando nossos equívocos". ${ }^{99}$

\footnotetext{
${ }^{99}$ Extraído de artigo eletrônico da Revista Bahia Invest de junho de 2006, ver site: http://www.seplan.ba.gov.br/bahiainvest/port/perfil.php?find=versa0008

* Karl M annheim (1893-1947) - sociólogo alemão, professor de Sociologia em

Frankfurt e Londres. Sua obra mais influente - Ideologia e Utopia (29) - afirmava
} 


\section{Lourival Gomes Machado}

Nascido em Ribeirão Preto em 1917, Lourival Gomes M achado

bacharelou-se em Direito e Ciências Sociais em 1938. Como crítico de arte publicou vários artigos em jornais e revistas sendo professor da Faculdade de Filosofia, Letras e Ciências Humanas desde 1939 e da Arquitetura e Urbanismo da Universidade de São Paulo no biênio 61-62. Organizou e instalou a $1^{\text {a }}$. Bienal Internacional de São Paulo em 1951. Não havia muitos críticos de arte naquele tempo e, portanto, Mário Pedrosa e Lourival concorriam, um no Rio de Janeiro, outro em São Paulo.

Disputavam a primazia de construir uma crítica embasada não apenas em fundamentos estéticos, mas também sócio-culturais. Era a época em que Mannheim* perturbava as mentes com a Sociologia do Conhecimento e a Gestalt e a Psicologia Social davam um ar novo e diferente à maneira de ver as artes plásticas.

Lourival era um homem político que discordava dos rumos que trilhava a política brasileira. No início da década de 60, assumiu o Departamento de Assuntos Culturais da Unesco em Paris. Entre suas principais obras publicadas estão: Retrato da arte moderna no Brasil (47); Teorias do

que todo conhecimento não resulta simplesmente de uma consciência teórica, mas de outros elementos provenientes da vida social e das influências e vontade que 0 indivíduo está sujeito. Em cada fase da humanidade apareceriam teorias conflitantes, tendendo ou para a conservação, ou para a mudança. A primeira tenderia a produzir as ideologias e a segunda, as utopias. barroco (53); Reconquista de Congonhas (60) e Barroco mineiro (69). Faleceu em Milão na Itália no ano de 67.

Em seu livro de 47, Lourival escreveu sobre A renovação da arquitetura brasileira onde constatava que a vinda de Le Corbusier, convidado pelo grupo de arquitetos cariocas encarregados pela construção do Ministério da Educação e Saúde, teria sido o grande impulso que alavancou a chamada arquitetura moderna brasileira.

"A visita de Le Corbusier teve uma orientação marcadamente didática. Sua atitude fora a de estudar junto, encaminhando 0 esclarecimento das questões e a solução dos problemas. E a melhor prova de sua eficiência como professor se patenteia por ter deixado aqui, ao se retirar, não o risco de um prédio público, mas um grupo de jovens arquitetos capacitados a resolver esse problema urgente, e mais, de construir, como vieram posteriormente a construir, as melhores amostras contemporâneas do país". ${ }^{100}$

\section{Programa proposto}

Um ofício assinado pelo então secretário geral Júlio Mário Stamato levou ao conhecimento do diretor da Faculdade de Arquitetura e Urbanismo, Pedro Bento José Gravina que no Conselho Universitário reunido em 23 de janeiro de 1956 havia sido aprovado o novo programa para a cadeira $n$.

${ }^{100}$ XAVIER, Alberto (org.) Depoimento de uma geração. Cosac \& Naify, São Paulo, 2003, pg. 77 
16 'Composição de Arquitetura - Pequenas Composições I - Desenho Arquitetônico - Plástica ( $1^{\mathrm{a}}$. e $2^{\mathrm{a}}$. partes)' .

0 programa proposto para o $1^{\circ}$. Ano do curso em 1956 era:

- Apresentação dos materiais de construção mais usuais; seu emprego sob ponto de vista estrutural, de vedação e plástico.

- Equipamento da habitação; material sanitário, eletrodomésticos, armários, mesas e cadeiras.

- Elementos que compõem a construção do ponto de vista funcional e construtivo.

- O homem como modulador do espaço; os elementos construtivos e espaciais em relação às proporções humanas.

- Organização dos espaços internos e externos da habitação.

- Interdependência dos ambientes interno e externo na habitação contemporânea

- Análise do local: situação, orientação, vizinhança, interpretação de levantamento.

- Discussão de programas mínimos de habitação e organização de projetos.

Seriam estabelecidos exercícios referentes a: detalhes diversos de construção; organização dos espaços internos e externos de uma habitação; projeto de residência para família pequena.

Para o 2‥ Ano, o programa seria:
- Detalhes construtivos de edifícios e pequenas estruturas: Fundações, Paredes, Estruturas simples, Cobertura, Acabamentos, Instalações elétricas, hidráulicas e águas pluviais.

- Situação dos edifícios no terreno e aproveitamento de lotes urbanos.

- Noções de insolação. Interpretação das disposições legais contidas nas codificações sobre instalações.

- A vida interna do edifício: o programa. Circulação interna em residências e outros casos. Distribuição em planta em função da circulação.

Os exercícios seriam: projeto de pequena residência e discussão coletiva dos trabalhos; estudo de um sobrado atentando para a ligação entre andares: escadas, rampas, elevadores; estudo de habitação coletiva e sua insolação; estudo de projeto com programa específico (pequenas estações, restaurantes, posto de serviços).

A disciplina de Plástica I (a partir do 2ํ․ Ano) discorreria sobre:

- Noções elementares de geometria plana. A medida áurea. As leis da forma (Gestalt). Noções sobre cores primárias e neutras.

- Noções elementares de geometria espacial. Sólidos regulares. Noções de espaço plástico: estático e dinâmico; espaço- 
tempo; cheios e vazios; articulação de volumes; a cor como elemento espacial.

Já a disciplina de Desenho Arquitetônico (para o 1‥ Ano) teria o seguinte programa:

- Uso dos instrumentos de desenho: tira-linhas, grafos, normógrafos, esquadros, compassos, escalas, etc.

- Exercícios de representação em escalas diferentes: plantas, cortes, elevações e detalhes.

- Convenções usuais nos desenhos de instalações elétricas, água, gás, etc.

- Levantamento de edifícios e seus elementos.

- Representação dos diversos ambientes de uma edificação: cozinhas, banheiros, lavanderias, salas, dormitórios, refeitórios, etc.

- Desenhos de apresentação de anteprojeto e estudos.

- Desenhos técnicos de execução.

- Desenhos de projetos nos termos da legislação em vigor.

Destacavam-se ainda os assuntos e conhecimentos correlatos ao programa da disciplina que deveriam ser desenvolvidos pelo professor:

- A arquitetura e conceitos. Expressão, correlação, integração.

- Problemas sociológicos e grupos sociais.
- Complexidade do fato arquitetônico. Função, estrutura econômica e síntese estética.

- Estética sociológica e psicológica. Arte, indústria e sociedade.

- O espaço e sua integração. Concepções através da história.

- Problemas de psicologia experimental. Sensações e imagens.

- Salubridade, saúde física e espiritual. Clima e micro clima.

- Sistemas construtivos. Esqueleto e membranas. Aço, concreto e madeira.

- Economia. Simplicidade e pureza da forma.

- O plano como gerador. Flexibilidade e uso múltiplo do espaço.

- O problema da habitação. Circulação. 0 edifício e a cidade.

- Vida e aura das formas. Forma e tempo, função, teoria, cor, tradição.

- Arquitetura e seu ensino.

- Os estilos, suas origens e tendências.

- Os elementos da Arquitetura. Elementos estruturais, de proteção, de circulação e decoração. História e filosofia.

- Teoria da Arquitetura. Fatores de ordem material, social, econômica e psicológica. ${ }^{101}$

\footnotetext{
${ }^{101}$ Extraído de documento original presente na pasta de Zenon Lotufo na Seção Pessoal da FAU-USP.
} 


\section{Candidatos}

Inscreveram-se para o Concurso, além de Zenon Lotufo, os seguintes arquitetos: Mário Russo, Paulo Camargo de Almeida e Ernest Robert de Carvalho Mange.

Mário Russo era italiano formado pelos princípios da escola racionalista na Itália. Em 49, transferiu-se para Recife, onde projetou o campus da Universidade Federal, seguindo como chefe do Escritório Técnico da Cidade Universitária, ficando na cidade até 55 . Projetou os prédios para a Faculdade de Medicina e o Hospital das Clínicas, o Instituto de Antibióticos e o Instituto de Biologia Marítima.

Paulo Camargo de Almeida (1906-1973) foi o arquiteto carioca que presidiu a direção nacional do Instituto dos Arquitetos do Brasil em 43. Participou junto com a equipe de Vilanova Artigas e Carlos Cascaldi, do concurso para o Plano Piloto de Brasília em 57, obtendo o quinto lugar na competição. Foi diretor executivo do FUNDUSP entre 60 e 65.

Ernest Robert de Carvalho Mange (1922-2005) nasceu em São Paulo. Filho de engenheiro suíço e professor da Escola Politécnica, onde estudou de 40 a 45. Foi estagiário no escritório de Rino Levi e Le Corbusier. Participou nos anos 70 com Hélio Duarte, do projeto e construção de várias escolas do Convênio Escolar e Senai.

Foi presidente da Empresa Municipal de Urbanização (EMURB). Projetou o Conjunto Indaiá (blocos de apartamento) em Santos, novamente com
Hélio Duarte; o Bloco E-1 na Escola de Engenharia de São Carlos, o Plano Diretor de Ilha Solteira (68) e o Instituto Itaú Cultural (95), na Avenida Paulista, entre outros tantos.

Este brevíssimo resumo de algumas das atividades desenvolvidas pelos candidatos, antes e depois do Concurso, serve para ilustrar um pouco do gabarito e a qualidade profissional que estavam sendo avaliados na solenidade acadêmica em questão.

\section{O espaço psicológico na Arquitetura}

0 ensaio apresentado por Zenon Lotufo para sua defesa de tese no concurso tornou-se um trabalho de referência para estudantes e mesmo professores. A simplicidade de suas palavras nunca afetou a qualidade do conteúdo das mesmas. 0 fato foi que em "O Espaço Psicológico na Arquitetura", Zenon Lotufo procurou discutir os aspectos psicológicos na organização dos espaços e sua relação com o homem, como comentamos a seguir. 


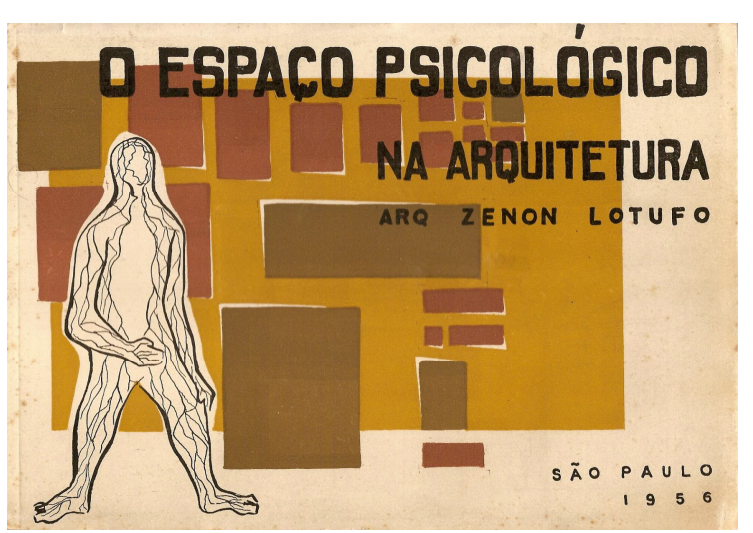

(Fig. 136) Capa ilustrativa da tese para o Concurso de Cátedra. Fonte: Arquivo da família.

Existem pontos interessantes que o arquiteto abordou já na introdução do ensaio como, por exemplo, a crítica que fez à excessiva classificação de movimentos e escolas nas artes e na arquitetura.

“Sim, por que não se admite que o arquiteto, o pintor, o escultor estejam simplesmente fazendo arquitetura, pintura ou escultura; para merecerem atenção e referências, precisam fazer arquitetura orgânica, cubismo, construtivismo, neo-plasticismo, surrealismo, abstracionismo, etc". ${ }^{102}$

${ }^{102}$ LOTUFO, Zenon. O Espaço Psicológico na Arquitetura. Tese elaborada para o Concurso Público para provimento do cargo de Professor Catedrático da Cadeira n. 16 'Composição de Arquitetura. Pequenas Composições I. Desenho Arquitetônico. Plástica I' do Curso de Arquitetura da Faculdade de Arquitetura e Urbanismo da Universidade de São Paulo. São Paulo, 1956, pg. 9.
Mesmo assim, Zenon trazia à tona seu otimismo e entusiasmo pelas questões contemporâneas da sociedade em constante evolução e a arquitetura que se desenvolvia naquele período. E mais diante, afirmava convicto:

"Há ainda hoje quem pense em arquitetura contemporânea, exclusivamente em função da forma, sob os aspectos puramente plásticos. Esquece-se completamente da função primordial do arquiteto que é a de organizar o espaço. M uito mais útil e necessário é o estudo e análise do espaço e sua organização nas obras históricas, do que a memorização de estilos, detalhe de fachadas, molduras e colunas. A composição espacial interna e externa dos edifícios reflete de certa maneira a vida de um povo, suas tendências, suas preocupações sociais, seus processos políticos". ${ }^{103}$

Seu texto se prontificava em apontar com simplicidade e clareza, a função social da arquitetura e a importância do arquiteto em ter a liberdade para exercer sua sensibilidade criativa, interpretando os problemas e fenômenos sociais e expressando seu pensamento.

Lotufo afirmou que havia uma diferença muito grande entre 0 arquiteto que atua de modo livre, expressando sua arte através da influência que recebe do seu meio, da filosofia de sua época e da cultura do seu povo, e

\footnotetext{
${ }^{103}$ Idem, pg. 10.
} 
o profissional que cumpre apenas as determinações que seu cliente lhe pede.

A primeira seria espontânea, característica fundamental da criação artística, e a segunda impositiva, portanto, destituída de expressão verdadeiramente artística, pois aniquilava algo extremamente valioso: a personalidade humana. E encerrando o capítulo, Zenon recuperava as quatro funções básicas da cidade moderna corbusiana, descrita na Carta de Atenas em 1933: habitar, trabalhar, circular e a cultivar o corpo e 0 espírito.

Entender os limites do tempo na sua divisão em acordo com as atividades do homem, ou seja, períodos para uma de cada destas funções em ambientes que satisfaçam seu conforto fisiológico e psicológico.

"O habitar não deve ser meramente 0 atendimento das necessidades físicas elementares. Deve ser a integração de uma solução espacial orgânica com o desejo humano por elementos visuais e plásticos. Ao se estudar as organizações espaciais de cada povo e cultura verificamse diferentes modos de se valorizar aspectos espirituais. Quanto mais culto e civilizado esses povos, maior a importância creditada aos valores espirituais". ${ }^{104}$

\footnotetext{
${ }^{104}$ Ibidem, pg. 15.
}

\section{Continuidade espacial}

Uma tendência natural do homem seria a conquista visual do exterior, ultrapassando os limites materiais dos espaços internos. Esta correlação entre ambiente interno e externo ficou enfatizado na tese por

continuidade espacial. Tratava-se, segundo Zenon, de uma das condições psicológicas mais necessárias à vida humana.

“M as a continuidade espacial deve ser tratada de tal maneira que sua influência sobre 0 ambiente não altere as qualidades indispensáveis à sua consideração como espaço psicológico". ${ }^{105}$

Para Zenon, deve-se estar muito atento ao emprego do princípio da continuidade espacial, pois as condições para que determinados ambientes desempenhem suas plenas funções devem estar em acordo com as necessidades psicológicas de seus usuários.

Outro conceito desenvolvido em sua tese foi a questão da

\section{proporcionalidade espacial.}

“Devendo existir proporcionalidade e relação com o meio ambiente e as funções necessárias ao desempenho das atividades humanas, em uma composição plástica que satisfaça simultaneamente aos valores espirituais. 0 engenheiro calcula o espaço exato ou fisiológico; o arquiteto organiza o espaço psicológico". ${ }^{106}$

\footnotetext{
${ }^{105}$ Ibidem, pg. 28.

${ }^{106}$ Ibidem, pg. 29.
} 
Para Zenon, esta seria a principal diferença entre a obra do engenheiro e do arquiteto. É notável o parentesco dessas palavras com as de Le Corbusier em Por uma arquitetura, como vimos anteriormente.

\section{Evolução social}

Outro fenômeno que Lotufo enfatizou em seu texto foi o da evolução

social. Para ele, os edifícios tenderiam a responder aos usos de um determinado grupo social. No entanto, com o passar do tempo, este grupo poderia mudar ou mesmo o próprio uso tenderia a uma mudança. Neste caso, o edifício perde sua razão de existir, devendo encontrar nova destinação de uso, caso pretenda-se que o mesmo sobreviva. Ou seja, uma adaptação frente a uma nova exigência, ou um novo cenário que atenda a uma nova demanda, se esta existir.

Para Zenon, bastaria imaginar nos castelos medievais ou mesmo nos palácios renascentistas. Em determinado período da história cumpriam importante função social na vida das comunidades, tornando-se com o passar dos tempos, obsoletos e desnecessários frente aos usos que se fizeram presentes.

Assim, o processo de evolução social e científica das civilizações humanas é inevitável. Basta observar o exemplo, segundo Lotufo, dos meios de locomoção. 0 cavalo, a máquina a vapor, o motor a combustão, o avião. 0 fato é que este fenômeno reflete diretamente na organização dos espaços utilizados pelo homem e, portanto no modo de conceber e planejar nossas cidades, sendo necessária, uma intervenção constante com o intuito de adaptar da melhor maneira: usos, técnicas e contextos.

"A excelência de tais criações não pode ser negada, como não 0 poderá ser igualmente, a possibilidade de novas manifestações espaciais que, psicologicamente, resolvam os problemas de cada época, no conteúdo, na forma e na estrutura". ${ }^{107}$

Numa definição primorosa sobre arquitetura no livro Precisões, Le Corbusier também comentou sobre a necessidade de sua arte se adaptar às mudanças contínuas da sociedade:

"Arquitetura é um encadeamento de acontecimentos sucessivos, que vão da análise à síntese. Acontecimentos que o espírito tenta tornar sublime, através da criação de relações tão precisas e perturbadoras que delas decorrem sensações fisiológicas profundas. Intervêm um verdadeiro deleite espiritual ao lermos o problema resolvido e alcançarmos uma percepção da harmonia, graças à qualidade matemática que une cada elemento da obra aos demais, e o conjunto dela ao meio ambiente onde está, o local. 0 próprio da criação é equacionar relações forçosamente novas, pois um dos termos é fixo - a sensibilidade humana - e o outro está sempre em movimento - as contingências, isto é, o meio formado pela

\footnotetext{
${ }^{107}$ Ibidem, pg. 37.
} 
qualidade técnica em todos os setores, de uma sociedade em perpétua evolução". 108

Oscar Niemeyer, do mesmo modo, em artigo recente também comentou que:

“Não foi apenas o progresso da técnica que marcou a evolução da arquitetura, mas também as transformações das ciências e da sociedade". ${ }^{109}$

\section{Correlação dos espaços}

Segundo Zenon, examinando, por exemplo, os templos gregos da Antiguidade clássica verificavam-se também uma preocupação desses povos em adequar suas construções às condições geográficas, ao clima, à paisagem e à topografia.

A correlação dos espaços era uma das preocupações relacionadas por Lotufo onde a forma arquitetônica seria determinada pelo modo como os espaços internos estariam organizados.

“A perfeita harmonia entre invólucro e a organização interna do espaço, permitirá sua natural expansão, além dos limites materiais a que está circunscrito, sem perder suas qualidades intrínsecas. Essa harmonia

${ }^{108}$ CORBUSIER, L. Precisões sobre um estado presente da arquitetura e do urbanismo. São Paulo, Cosac e Naify, 2004, p 160.

${ }^{109}$ Niemeyer, Oscar. Conversa de arquiteto Artigo publicado no jornal Folha de São Paulo em 16 de julho de 2006, caderno A, p. 3. adiciona-lhe uma espécie de força espiritual, capaz de influenciar e modificar o espaço externo. Este igualmente influenciará o ambiente interno, havendo não propriamente uma compensação, mas sim, um acréscimo mútuo de valores. Haverá uma interpenetração com vantagens reais recíprocas". (LOTUFO, 1956, pg. 49-50)

\section{Zenon continua seu texto relatando a ineficácia das cidades e das} metrópoles atuais e os males que a desorganização política e a ausência de planejamento e controle para direcionar o crescimento do território, resultaram somente em espaços restritos e apertados.

Os processos de verticalização intensos coincidente com um mercado imobiliário que se valeu do máximo aproveitamento de construção produziram o enclausuramento do homem contemporâneo, fechado em seu minúsculo apartamento, não consegue gozar de situações favoráveis ao seu conforto físico nem psicológico.

Cabe salientar que o principal interessado e ao mesmo tempo menosprezado é o próprio homem, cujas necessidades e aspirações deveriam ser o ponto de partida para todas as soluções urbanísticas. 


\section{Toda cidade é uma casa. Toda casa é uma cidade}

No capítulo seguinte, Zenon resgataria um importante ensinamento de Alberti ${ }^{110}$ quando diz que os espaços abertos e externos seriam a

continuidade da habitação. Pois o sentido de habitar não está apenas na moradia particular, ela se estender no território urbano-rural como um

todo. Essa correlação de espaços é discutida por Zenon tendo como foco 0 aspecto psicológico na relação homem e meio ambiente.

“Não se trata de grandes avenidas ou extensas praças. Procura-se a correlação entre as organizações espaciais, a proporção, o equilíbrio, estudando-se o comportamento do homem em relação ao ambiente, para que não se sinta constrangido, atemorizado ou preocupado, mas sinta emoções agradáveis, conforto físico e espiritual, segurança e bem-estar" (LOTUFO, 1956, pg. 58).

Assim, Lotufo reforçou sua crença nos valores estéticos clássicos necessários à obra arquitetônica: proporção, equilíbrio, harmonia e unidade na variedade.

“A emoção estética não é produzida pelo acaso, pela distribuição indiscriminada de volumes e cores, de cheios e vazios; mas sim conseqüência lógica da organização inteligente, ordenada e plástica do

${ }^{110}$ Leon Battista Alberti (1404-1472), arquiteto e teórico do Renascimento italiano, escreveu o célebre tratado de arquitetura, baseado na harmonia dos números e das proporções na arte da Antiguidade: De re aedificatoria (1452). espaço. Cada edifício ou conjunto de edifícios, cada monumento, praça ou logradouro, devem ter seu lugar e sua razão de ser no complexo urbano" (LOTUFO, 1956, pg. 59).

Em seguida, Lotudo reproduz um conceito desenvolvido por Eliel Saarinen (1873-1950) em seu livro "Busca pela Forma" ("Search for Form”)

chamado "embracing space".

"Em qualquer circunstância, toda obra de arte deve estar disposta de modo a fazer parte integral do espaço que a envolve, deve estar em harmonia com os vários fatores de sua esfera de influência, deve ser expressiva de significado e sentido em seu espaço envoltório (embracing space) e deve atender as funções de sua razão de existir". ${ }^{111}$

\section{Tradição criadora}

0 instinto criador dos gregos preocupava-se atentamente com o trato do ambiente externo, ou seja, da correlação entre a obra de arte e o local onde estará.

De modo que contribuísse para originar a noção de continuidade espacial, unidade de composição e harmonia de conjunto.

Novamente trazem o exemplo da Acrópole grega salientando o valor plástico de cada peça dentro do conjunto e a zona de influência de uns com os outros, respeitando e apoiando intrinsecamente.

\footnotetext{
${ }^{111}$ Saarinen, Eliel. Search for Form p. 131.
} 
"Os princípios que os orientaram, as causas determinantes de adoção de certos critérios construtivos e plásticos, conseqüência de circunstâncias e fatores peculiares ao meio, ao clima, à organização social, à técnica conhecida, enfim todo esse complexo que aliado à intuição, modela uma obra de arte, por muito tempo" (LOTUFO, 1956, pg. $66)$.

\section{Novos rumos}

Comentando sobre o modo recente que a arquitetura moderna despontou e os rótulos que Ihe foi atribuída, entre eles, funcionalista ou racionalista, Zenon qualificou estas características como sendo inerentes à qualquer obra de arquitetura verdadeira. Do contrário, seria obra de engenharia.

Criticou também a necessidade material imediata da sociedade contemporânea que se preocupava muito mais com os aspectos formais e os estilos de moda, valorizando o máximo aproveitamento dos espaços do que os verdadeiros fundamentos da arquitetura: a satisfação das necessidades psicológicas do homem.

O progresso tecnológico e científico, segundo Lotufo, estaria escravizando o ser humano, pois à medida que colocava à disposição os meios técnicos adequados à concretização de suas idéias, criava maior competição por produtividade e lucros.
Outro autor citado no ensaio foi Herbert Read (1893-1968), crítico de arte inglês que no seu livro "The Grass Roots of Art" destacava que a grandeza da Arquitetura se encontraria numa determinada estrutura social, animada por um espírito político ou religioso, mas que essencialmente relacionasse eficiência, integridade, singeleza e intimidade.

No desfecho do ensaio, Zenon ressaltou a complexidade de organização da cidade moderna. Suas mudanças como sendo muito rápidas e constantes, de forma e caráter. Mas sua morte não poderia ser comparada a de um organismo. Só morreria, quando parasse de evoluir. E citando o filósofo Henri Bérgson ${ }^{112}$ em A Evolução Criadora: “Duração significa invenção, criação de formas, elaboração contínua do novo". Para Lotufo, o que determinaria a evolução das cidades, este fantástico fenômeno fruto das organizações espaciais relacionadas entre si por contigüidade, seria o próprio homem, fator único de sua existência. Sendo o homem, uma criatura dotada de emoção e razão, espírito e matéria, sua casa-cidade não poderia abdicar de nenhum desses aspectos para satisfazer seus anseios e necessidades.

\footnotetext{
${ }^{112}$ Henri Bérgson (1859-1941), influente filósofo francês, da primeira metade do século XX. Ganhador do Prêmio Nobel de Literatura em 1927. Buscou superar o positivismo e o idealismo do século XIX. Suas obras mais importantes: M atéria e memória (1896) e A evolução criadora (1907).
} 


\section{Resultado polêmico}

O relatório final da banca examinadora do Concurso de Cátedra ${ }^{113}$

contendo 35 páginas descreveu o conteúdo de atividades desenvolvidas pelos candidatos, as provas, os critérios de avaliação, as notas, os pontos sorteados e os temas escolhidos, e a seguir, reproduzimos seus aspectos principais.

O Concurso teve seu início em 9 de agosto de 1957, às 10 horas da manhã, quando o então diretor da Faculdade de Arquitetura e Urbanismo da Universidade de São Paulo, Prof. Dr. Pedro Bento José Gravina empossou os membros da Comissão Julgadora.

Assumindo então a presidência da banca examinadora o Prof. Dr. José Benedito de Camargo tendo como secretário o também professor e doutor, Lourival Gomes Machado, a primeira providência foi determinar a seqüência e os horários das provas a serem aplicadas.

Sendo feita a seguinte programação e distribuição de horários:

dia 9 - 15 horas: Julgamento de títulos

17 horas: Organização dos pontos para a prova escrita

dia 10 - 8 horas: Realização das provas escritas

dia 12 - 7:30 horas: Sorteio de ponto da prova prática

\footnotetext{
${ }^{113}$ Extraído de reprodução de documento original datilografado do Arquivo Histórico e Técnico da FAUUSP.
}

8 às 12 e 14 às 18 horas: Início da prova prática dia 13 - 8 às 12 e 14 às 18 horas: Continuação da prova prática

dia 14 - 8 às 12 e 14 às 16 horas: Continuação da prova prática

16 às 18 horas: Redação de relatório das provas práticas pelos candidatos / Julgamento e encerramento da cédulas

dia 15 - 8 horas: Leitura da prova escrita

a seguir: Julgamento e encerramento das cédulas dia 16 - 8 horas: Defesa de tese de Zenon Lotufo

A seguir: Julgamento e encerramento de cédula

15 horas: Defesa de tese de Mário Russo

A seguir: Julgamento e encerramento da cédula

Dia 17 - 8 horas: Defesa de tese de Paulo de Camargo e Almeida.

A seguir: Julgamento e encerramento da cédula

15 horas: Defesa de tese de Ernest Robert de Carvalho Mange.

A seguir: Julgamento e encerramento da cédula Dia 18 - 9 horas: Sorteio de ponto de prova didática para Zenon Lotufo e Mário Russo. 
14 horas: Sorteio de ponto de prova didática para Paulo de Camargo e Almeida e Ernest Robert de Carvalho

Mange.

Dia 19 - 9 horas: Realização da prova didática de Zenon Lotufo e Mário Russo.

A seguir: Julgamento e encerramento das cédulas

14 horas: Realização da prova didática de Paulo de

Camargo e Almeida e Ernest Robert de Carvalho Mange

A seguir: Julgamento e encerramento das cédulas

16 horas: Sessão final pública de apuração dos resultados

do concurso e encerramento dos trabalhos.

\section{Julgamento de títulos}

A primeira avaliação levou em conta o julgamento dos títulos dos candidatos e os critérios de avaliação levaram em conta as seguintes prioridades:

- dignidade universitária do candidato

- trabalhos científicos e publicações

- atividade didática

- atividade profissional correlacionada à matéria da cadeira

\section{Prova escrita}

A prova escrita realizou-se no dia seguinte (10) sob fiscalização dos membros da comissão julgadora sendo concedida aos candidatos duas horas de consultas.

A lista de 10 pontos foi apresentada pela Comissão às 7:30 horas e abrangiam, de certo modo, todo programa proposto para a cadeira:

1. Situação da arquitetura na estética contemporânea

2. Influência da habitação no comportamento individual e social

3. Técnica e materiais na arquitetura brasileira atual

4. Economia da arquitetura

5. Possibilidades do monumental na arquitetura atual

6. Discussão da validade e permanência dos princípios de composição

7. Forma e tradição na arquitetura brasileira, o barroco e o racional

8. Educação artística na formação do arquiteto

9. Estilo em arquitetura

10. Realidades e meios de representação em arquitetura; correlação e divergência.

A seguir, o primeiro candidato inscrito Zenon Lotufo foi convidado a sortear o ponto a ser realizado na prova escrita, retirando da urna o tema de número 5. Ficou estipulado um prazo de 6 horas para a realização da prova. 
E sua leitura e correção ocorreram no dia 15 pelos candidatos. 0 primeiro a iniciar foi Zenon Lotufo, que leu sua prova contendo 9 páginas de folha almaço. Seguido por Mário Russo que continha 5 folhas, depois Paulo de Camargo e Almeida, com 6 páginas e finalmente, Ernest Mange contando com 17 páginas.

Logo após, esta sessão de leitura, os membros da Comissão atribuíram notas de mérito para cada candidato em cédula especial e após assinarem, o conteúdo foi lacrado em envelope opaco e depositado em urna inviolável que ficou em posse do Secretário da Faculdade.

Zenon Lotufo discorreu em sua prova escrita sobre o ponto sorteado pela banca avaliadora: Possibilidades do M onumental na Arquitetura Atual.

Sua atenção inicial voltou-se para a definição da palavra monumento que segundo ele não seria algo com dimensões enormes, mas sim 0 significado que uma obra adquire diante da necessidade humana em criála.

"A História da Arquitetura nada mais é que a catalogação dos monumentos dos povos civilizados onde suas obras de arte têm raízes profundas na cultura, religião, condições sociais, possibilidades técnicas, materiais e econômicas de cada povo". ${ }^{114}$

${ }^{114}$ Prova escrita a mão por Zenon Lotufo datado de 10 de agosto de 1957 em São Paulo por ocasião do concurso publico para provimento de cargo de professor catedrático na cadeira 16 da Faculdade de Arquitetura e Urbanismo da Universidade de São Paulo, trecho extraído do documento original, pg. 1-2.
Dando continuidade, Lotufo argumentou sobre as possibilidades grandiosas que a técnica da sua época, apoiada na industrialização dos componentes do edifício ou estandardização, ofereciam em comparação à arquitetura clássica tradicional. Era um momento inédito na história da humanidade.

"Assim, a arquitetura, não abandonando o funcionalismo, tirando as maiores vantagens da capacidade da máquina e da técnica, aliando-se à pintura e à escultura, de quem tem estado divorciada, há muito tempo, procurando humanizar cada vez mais sua conceituação plástica e espacial (no sentido verdadeiro do homem-espírito) fatalmente há de chegar a uma síntese estética da arquitetura: Função, Forma, Estrutura e

Economia, alicerces poderosos sobre o qual se levantará a arquitetura monumental contemporânea". ${ }^{115}$

Ao término de sua elaboração, concluiu criticando as reais condições da realização de trabalho para os arquitetos:

"O arquiteto tem enormes possibilidades técnicas, materiais e plásticas para realizar o monumental, mas desde que a sociedade se reeduque e disponha de seu talento e capacidade".

\footnotetext{
${ }^{115}$ Idem, pg. 7.
} 


\section{Prova prática}

A Comissão havia se reunido no dia 9 e elaborado uma lista prévia dos seguintes programas a serem sorteados para a prova prática, que foram anunciados após serem melhor elaborados, no dia 12, às 7 e 30 horas, constando dos seguintes temas:

1. Residência rural: sede de fazenda

2. Edifício de apartamentos para aluguel

3. Estação rodoviária terminal

4. Restaurante tangente à estrada tronco

5. Prefeitura para cidade de 30 mil habitantes

6. Creche anexa à fábrica de tecidos

7. Mercado para bairro da capital com 15 mil habitantes

8. Hotel de cidade balneária de praia, para 100 hóspedes

9. Residência urbana para escultor e família

10. Sede social de clube esportivo para 1000 sócios

A seguir, o candidato inscrito em primeiro lugar foi convidado a sortear um número que corresponderia ao programa a ser desenvolvido na prova prática. Zenon Lotufo retirou o papel de número 3 e assim a Comissão entregou aos candidatos por escrito, indicações visando maior precisão no desenvolvimento do programa, da seguinte maneira:

1. Plataforma de acostagem (10 partidas/hora)

2. Venda de passagens (4 boxes)
3. Serviço de recepção e expedição de bagagens

4. Administração da rodoviária

5. Polícia

6. Serviço de encomendas

7. 4 salas para pessoal de tráfego, com instalações sanitárias

8. Pronto socorro

9. Serviços de conforto de passageiros (banheiros, bar-restaurante, estar, banca de jornal e depósito de bagagens)

0 projeto deveria compreender fundamentalmente: organogramas, esquemas de distribuição e estrutura, plantas baixas (incluindo planta de situação), cortes, fachadas, perspectivas e detalhes construtivos. Os desenhos poderiam ser apresentados á mão livre, a nanquim ou lápis preto sobre papel vegetal, sendo que a perspectiva deveria ser pelo menos proporcionada pelo método geométrico exato.

Portanto nos dias 12, 13 e 14, em sessões de oito horas de trabalho com intervalo para o almoço, realizaram-se as provas práticas sendo que no fim da primeira sessão, os candidatos deveriam apresentar o estudo inicial do projeto a ser desenvolvido nas duas sessões subseqüentes. No julgamento da prova prática adotou-se os seguintes critérios: situação urbana e circulação externa, partido em planta e da circulação interna, elevações, estrutura e configuração plástica. 


\section{Defesa de tese}

Nos dias 16 e 17, os candidatos foram submetidos às provas de defesa da tese apresentada, sendo Zenon Lotufo e Mário Russo avaliados no primeiro dia, enquanto Paulo de Camargo e Almeida e Ernest Robert Carvalho Mange, ficaram com o segundo dia.

0 primeiro candidato foi Zenon Lotufo que iniciou às 8 horas, a defesa de sua tese "O espaço psicológico na Arquitetura". Logo após a

apresentação, o candidato foi argüido sucessivamente pelos membros da Diógenes Rebouças, Demétrio Ribeiro, Sylvio de Vasconcelos, Lourival Gomes Machado e José Benedicto de Camargo que respeitaram o prazo de 30 minutos permitidos a cada um deles. A prova terminou às 13 horas e 25 minutos, tendo cada professor da Comissão atribuído uma nota de mérito com rubrica e encerrada em envelope opaco e depositado na mesma urna.

No mesmo dia, procedeu-se a defesa do segundo candidato Mário Russo a partir das 15 horas, com a tese "A tradução arquitetônica da célula habitativa - sua evolução e previsão lógica", terminando por volta das 19 horas a sua avaliação.

No dia seguinte, dia 17, aconteceram as defesas respectivas de Paulo de Camargo e Almeida pela manhã com a tese "A função social do arquiteto". E por fim, no período vespertino, o último candidato Ernest Robert de Carvalho Mange com o título "A função abrigo em Arquitetura".
Todas as defesas ocorreram da mesma forma, com os professores fazendo a argüição seguindo de atribuição de nota aos candidatos, lacradas em envelope e colocadas em urna especial.

\section{Prova didática}

E finalmente nos dias 18 e 19 de agosto, os candidatos fizeram a última prova que foi a prova didática em duas turmas distintas: Zenon Lotufo e Mário Russo.

Foi lida pelo Presidente da Banca a lista de pontos escolhidos do programa da cadeira, a ser sorteado:

1. Análise da orientação e situação dos edifícios no terreno

2. Esquemas funcionais: integração horizontal e vertical

3. Os elementos da arquitetura: circulação

4. O edifício e a saúde física e espiritual

5. Os elementos da Arquitetura: estruturais e de proteção

6. Complexidade do fato arquitetônico: função, estrutura econômica, síntese estética.

7. O edifício e a cidade.

8. Os espaços e sua manipulação. 0 ambiente e a respectiva integração.

9. Elementos da arquitetura: decoração.

10. Economia, simplicidade e pureza das formas. 
Nenhum dos candidatos ofereceu qualquer tipo de objeção aos temas propostos e a seguir, às 9 horas e 50 minutos, procedeu-se o sorteio pelo candidato Zenon Lotufo que retirou o número 5 da urna: Os elementos de arquitetura: estruturais e de proteção.

No período da tarde realizou-se o sorteio do ponto a ser desenvolvido pelos outros candidatos: Paulo de Camargo e Almeida e Ernest Robert de Carvalho M ange. Nesta ocasião, o tema sorteado por Paulo Almeida fora "Interdependência dos ambientes interno e externo na habitação".

No dia posterior pela manhã, dia 19, iniciou-se a realização da prova dos candidatos Zenon Lotufo, às 9 horas e 50 minutos, seguido por $\mathrm{M}$ ário Russo, ambos tendo à disposição o tempo corrido de 50 minutos. Ao final de suas exposições, os membros da Banca atribuíram uma nota para cada arquiteto em cédula especial que com assinatura foram encerradas em envelope opaco e também rubricado e depositados na mesma urna. Às 14 horas do mesmo dia, foram realizadas as provas dos outros candidatos, que tiveram o mesmo tempo (50 minutos) para versarem sobre o tema sorteado para eles: Interdependência dos ambientes interno e externo na habitação.

A sessão encerrou-se às 16 horas e 20 minutos, e imediatamente foi convocada reunião para se realizar a apuração final dos resultados e notas dos candidatos, sendo solicitada a abertura da urna com os envelopes, e a consecutiva abertura dos mesmos e lidas as notas obtidas.
Tendo em vista o resultado final da apuração, o senhor presidente da Comissão J osé Benedicto de Camargo declarou não haver nenhum candidato habilitado ao cargo pretendido.

Então, o vice-diretor em exercício da Faculdade de Arquitetura e

Urbanismo, Pedro Bento José Gravina agradeceu a estimada colaboração prestada ao concurso pelos professores que integraram a Comissão

Julgadora e declarou encerrada a sessão. Assim, reproduzimos o quadro de notas conferidas aos candidatos em cada uma das provas realizadas, cuja apuração foi realizada ao fim das provas didáticas. 


\begin{tabular}{|c|c|c|c|c|c|c|}
\hline \multicolumn{7}{|c|}{ Zenon Lotufo } \\
\hline Comissão Julgadora & $\begin{array}{l}\text { Proval } \\
\text { de Tí } \\
\text { los. }\end{array}$ & $\left.\begin{array}{|c|}\text { Prova } \\
\text { Práti } \\
\text { ca }\end{array}\right]$ & {$\left[\begin{array}{c}\text { Prova } \\
\text { Escri } \\
\text { ta }\end{array}\right]$} & \begin{tabular}{|c|} 
Defesa \\
de \\
Tése
\end{tabular} & $\begin{array}{l}\text { Prova } \\
\text { Dida- } \\
\text { tica }\end{array}$ & Médias \\
\hline Prof.Dr.José Benedicto de Camargo & 7,5 & 9,0 & 8,0 & 6,5 & 6,5 & 7,5 \\
\hline Prof.Dr.Sylvio de Vasconcellos & 8,0 & 8,0 & 6,5 & 5,0 & 5,0 & 6,5 \\
\hline Prof.Dr.Demétrio Ribeiro & 8,0 & 7,5 & 6,5 & 5,5 & 6,0 & 6,7 \\
\hline Prof.Dr.Diógenes Rebouças & 8,0 & 8,0 & 6,5 & 6,0 & 5,0 & 6,7 \\
\hline Prof.Dr.Iourival Gomes Machado & 7,5 & 8,0 & 6,0 & 5,0 & 5,0 & 6,3 \\
\hline \multicolumn{7}{|c|}{ Mario Russo } \\
\hline Prof.Dr.José Benedicto de Camargo & 7,0 & 6,0 & 6,0 & 7,5 & 7,5 & 6,8 \\
\hline Prof.Dr.Sylvio de Vasconcellos & 6,5 & 4,0 & 5,0 & 7,0 & 6,0 & 5,7 \\
\hline Prof.Dr.Demétrio Ribeiro & 7,0 & 5,0 & 6,5 & 7,0 & 6,5 & 6,4 \\
\hline Prof.Dr.Diógenes Rebouças & 6,5 & 5,0 & 5,0 & 6,5 & 5,5 & 5,7 \\
\hline Prof.Dr.Lourival Gomes Machado & 6,5 & 3,0 & 6,0 & 7,0 & 6,0 & 5,7 \\
\hline \multicolumn{7}{|c|}{ Paulo de Camargo e Almeida } \\
\hline Prof.Dr.José Benedicto de Camargo & 8,0 & 7,0 & 7,0 & 8,0 & 9,5 & 7,9 \\
\hline Prof.Dr.Sylvio de Vasconcellos & 7,0 & 5,0 & 6,0 & 7,0 & 7,5 & 6,5 \\
\hline Prof.Dr.Demétrio Ribeiro & 7,5 & 6,0 & 6,5 & 7,0 & 7,0 & 6,8 \\
\hline Prof.Dr.Diógenes Rebouças & 7,0 & 5,0 & 6,0 & 7,0 & 7,0 & 6,4 \\
\hline Prof.Dr.Lourival Gomes Machado & 7,0 & 4,0 & 6,5 & 7,0 & 7,5 & 6,4 \\
\hline \multicolumn{7}{|c|}{ Ernest Robert de Carvalho Mange } \\
\hline Prof.Dr.José Benedicto de Camargo & 7,0 & 8,0 & 9,0 & 7,5 & 8,5 & 8,0 \\
\hline Prof.Dr.Sylvio de Vasconcellos & 6,5 & 7,0 & 7,5 & 5,0 & 7,0 & 6,6 \\
\hline Prof.Dr.Demétrio Ribeiro & 7,0 & 7,0 & 8,0 & 6,0 & 6,5 & 6,9 \\
\hline Prof.Dr.Diógenes Rebouģas & 6,5 & 7,0 & 8,0 & 6,5 & 6,5 & 6,9 \\
\hline Paof.Dr.Lourival Gomes Machado & 6,5 & 7,0 & 7,5 & 5,0 & 7,0 & 6,6 \\
\hline
\end{tabular}

Fig. 137: Quadro de notas do Concurso de Cátedra. Fonte: Seção pessoal FAUUSP. Portanto, naquela ocasião um fato inédito aconteceu. Pela primeira vez na história da Universidade de São Paulo, a banca composta por José Benedicto de Camargo, Sylvio de Vasconcellos, Diógenes Rebouças, Lourival Gomes Machado e Demétrio Ribeiro considerou que 0 desempenho dos candidatos não fora à altura do cargo e reprovou a todos. Os candidatos protestaram juridicamente e o concurso acabou sendo cancelado.

\section{Repercussões}

"Claro que a questão política contava muito naquela época. Os grupos se dividiam nitidamente em direita, esquerda e centro. A postura

de Zenon nunca foi muito clara, não se posicionava claramente. A posição de nós, alunos, sempre foi desfavorável à Cátedra e ao concurso. Não era nada pessoal, contra o Zenon ou o Mange, por exemplo. Por isso, nossas vaias e a comemoração no fim do concurso". ${ }^{116}$

Após este episódio, Zenon Lotufo afastou-se das atividades acadêmicas, por quase dez anos, principalmente da FAU-USP. Ele se sentiu traído e injustiçado pela maneira como foi tratado pela instituição a que tanto se dedicara naqueles anos. Este fato marcou profundamente sua carreira acadêmica se desinteressando também de questões políticas, reuniões de classe, conselhos e mesmo da atividade didática.

Zenon voltaria às atividades didáticas acadêmicas apenas em 1966, portanto quase 10 anos depois, na Escola Politécnica como instrutor contratado, permanecendo até 0 início dos anos 70. E depois, retornaria à FAU, mas desta vez como auxiliar de ensino, permanecendo obscuro nos corredores da faculdade até se aposentar compulsoriamente em setembro de 1980.

\footnotetext{
${ }^{116}$ Depoimento de Jon M aitrejean, em 30 de outubro de 2007.
} 
Em 14 de março de 1969, Zenon Lotufo encaminhou ao então reitor da Universidade de São Paulo um requerimento solicitando sua estabilidade funcional na instituição, "por julgar satisfeitas as condições exigidas pelo Egrégio Conselho Universitário, não pela posse de um título, mas pelo longo período de exercício no Magistério Superior". Neste mesmo documento, revelava que exercera desde 1935, diversos cargos públicos. Inicialmente, como desenhista no Departamento de Obras Públicas da Prefeitura M unicipal de São Paulo, de 35 a 38, como engenheiro arquiteto auxiliar. Depois assistente de Anhaia M ello na Politécnica, no mesmo ano (38) na disciplina Composição de Arquitetura, e posteriormente também em 47.

Zenon Lotufo relatou que em 1957, "prestou concurso para o provimento da Cadeira de Composição de Arquitetura na Faculdade de Arquitetura e Urbanismo da Universidade de São Paulo, juntamente com mais três colegas". Esse concurso, disse ele, "eivado de sérias irregularidades, desde a insuficiência de formalidades legais, até a mais completa irresponsabilidade de certos membros da banca examinadora (dois deles cassados e com direitos políticos suspensos por 10 anos)".

Este concurso referido foi anulado pelo Egrégio Conselho Universitário, dando provimento ao recurso dos interessados, ou seja, os candidatos. O julgamento deste concurso prolongou-se por sete anos, prejudicando particularmente a Zenon Lotufo, que não se viu mais em condições de continuar ocupando a Cátedra mesmo que interinamente, razão pela qual solicitou sua dispensa. Este concurso, nunca mais foi reaberto para a cadeira em questão, impossibilitando 0 arquiteto de prestá-lo novamente.

0 arquiteto visou simplesmente o reconhecimento de sua dedicação à instituição pública, nos 35 anos em que trabalhou não conseguindo nem ao menos que seu nome permanecesse distintamente no quadro de exprofessores da faculdade. A obscuridade de sua passagem pela Faculdade de Arquitetura e Urbanismo da Universidade de São Paulo nos anos 70 também levanta suspeitas sobre a possível articulação política montada para apagar a figura de Zenon no referido concurso.

A Faculdade tinha sido recém-fundada em 1948, portanto era um curso recente. Como o Concurso para provimento da Cátedra tinha sido o primeiro realizado pela instituição, caso Zenon fosse aprovado, como professor catedrático concursado, automaticamente se tornaria o Diretor da Faculdade. 0 fato é que sua esposa Coraly (hoje, com 88 anos) revelou que pouco tempo antes de falecer, Zenon reclamou do modo como foi tratado pela USP e levava ainda consigo enorme mágoa da instituição. ${ }^{117}$

\footnotetext{
${ }^{117}$ Entrevista concedida por D. Coraly, em Botucatu, em 04 de outubro de 2007.
} 
Capítulo 3 - Brutalismo e maturidade (1958-85)

\subsection{Contextos}

Outro termo conceitual que começou a ser difundido internacionalmente foi o Brutalismo, que na verdade, se confundia com o uso do béton brut (concreto bruto) por Le Corbusier, material que celebrou a última fase criativa do arquiteto (45-65).

Este fato inicia-se com as obras do II pós-guerra, principalmente a Unidade de Habitação de Marselha (fig. 138) que acabou tornando-se referência para inúmeros arquitetos nas décadas de 50 a 70.

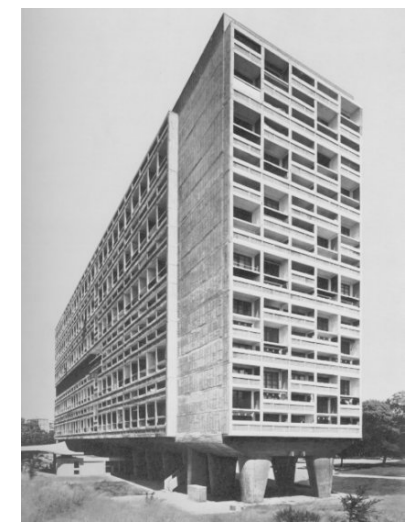

(fig. 138) Fonte: www.vitruvius.com.br.

Por sua vez, o Novo Brutalismo foi o nome adotado por uma nova geração de arquitetos britânicos que procurou sintetizar a natureza intrínseca dos materiais com as técnicas através das quais estes eram 
elaborados, numa tentativa de re-estabelecer uma unidade entre forma construída e modo de viver.

Na década de 50, esta nova direção da arquitetura revelou-se principalmente nos textos e projetos dos Smithsons (Peter e Alison) e de Reyner Banham para a revista Architecture Review . Na verdade, 0 emprego do termo servia apenas como bandeira frente à acomodação que o movimento moderno assumira, buscando acima de tudo, reavaliá10.

O Novo Brutalismo enquanto corrente ganhou força no final da década de 50 quando várias experiências foram realizadas por arquitetos ao redor do mundo, em São Paulo também, apresentando entre si as mesmas aproximações formais, construtivas e plásticas, e sistematizando um idioma arquitetônico comum nas décadas de 60 e 70.

No Brasil, talvez este movimento (Novo Brutalismo) não tenha tido o mesmo sentido social que teve na Europa, mas com certeza o resultado formal (desnudamento da estrutura e das instalações de serviços, prismas puros e elevados sob pilotis, verdade dos materiais, etc) fez escola entre os paulistas, tendo a frente principalmente, Vilanova Artigas e Lina Bo Bardi. ${ }^{118}$ Zenon Lotufo também compartilhou desta mesma linha nas décadas de 60 e 70, como passamos a observar em seus trabalhos.

\footnotetext{
${ }^{118}$ FUÃO, Fernando F. Brutalismo, a última trincheira do movimento moderno. em http:// www.romanoguerra.com.br/arquitextos/arq000/esp036.asp.
}

\section{CIAM X (1956)}

O próprio movimento moderno começou a passar por uma revisão interna de seus princípios ortodoxos em um de seus últimos eventos internacionais de divulgação: o CIAM X.

Os Congressos Internacionais de Arquitetura Moderna (CIAM) entraram em fase de contradição no pós II Guerra onde o discurso de integrantes como os Smithsons, Candilis, Bakema e Van Eyck mostravam uma mudança de direção dos postulados originais do movimento. 0 fato é que, para eles, o mundo havia mudado e o modernismo haveria de se adequar a este novo cenário. Assim, outras disciplinas humanas como Antropologia, Psicologia, Comunicação e Sociolgia começaram a ganhar maior participação na Arquitetura passando a influenciar as novas posturas. São deste período também (anos 50-70),por exemplo, as experiências sensorias e multicoloridas da arte psicodélica, a Pop-art, a cultura hippie e a flower generation. 0 estruturalismo também contribuiu para uma redefinição da arquitetura desta época seja na volta às origens (alguns arquitetos vão estudar sociedades primitivas), ou na questão da verdade estrutural e pureza da forma.

\section{Depoimento de Niemeyer (58)}

Em artigo escrito para a revista M ódulo no final dos anos 50, Niemeyer relatou que as obras de Brasília (57-60) haviam marcado uma nova etapa 
de seu trabalho, caracterizada agora por uma busca constante por pureza e síntese na solução estrutural mais simples e geométrica possível.

“Neste sentido, passaram a me interessar as soluções compactas, simples e geométricas; os problemas de hierarquia e de caráter arquitetônico; as conveniências de unidade e harmonia entre os edifícios e ainda, que estes não mais se exprimam por seus elementos secundários, mas pela própria estrutura, devidamente integrada na concepção plástica original". 119

Niemeyer relatava em certo tom de culpa os exageros formais cometidos em alguns projetos, o que estaria em contradição com o compromisso da arquitetura brasileira diante do seu quadro social. Seu descuido ao priorizar a originalidade e plasticidade das curvas havia prejudicado 0 sentido lógico da construção que deveria visar sempre a economia de meios e a simplicidade da forma.

Seu depoimento teve grande repercussão entre os paulistas que entenderam aquilo como uma revisão autocrítica do arquiteto carioca e começariam a desenvolver com maior intensidade uma nova linguagem formal, tendo como protagonista principal da composição arquitetônica: a estrutura.

\footnotetext{
${ }^{119}$ Niemeyer, Oscar. Depoimento. (fevereiro de 58) M ódulo n. 9 em Xavier, Alberto (org.). Depoimento de uma geração: arquitetura moderna brasileira. Cosac Naify, São Paulo, 2003, p. 239.
}

“O manifesto de 1958 foi prontamente sentido pelos colegas: seu conteúdo foi seminal para os arquitetos de esquerda e certamente tornouse um ponto de partida para uma nova "linha": um tipo de arquitetura feita em São Paulo, a "linha paulista". "120

\subsection{Parceria com Ubirajara Ribeiro (58-65)}

Zenon Lotufo havia sofrido imensa decepção com a FAUUSP no ano de 57 em virtude do resultado "desastroso" do Concurso de Cátedra. Ele havia se preparado um ano inteiro, estudando e escrevendo sua tese (0 Espaço psicológico na Arquitetura), mas não esperava de modo algum o ocorrido. De tal maneira que o arquiteto se ausentou do ensino e da academia e mesmo das representações políticas, voltando-se prioritariamente para 0 ofício da prancheta e do projeto.

Este período (58-65) ficou marcado principalmente pela parceria profissional com o arquiteto formado pelo Mackenzie, Ubirajara Ribeiro e pelos concursos públicos e privados que ambos realizaram e venceram. Ubirajara M otta Lima Ribeiro (1930-2002) foi arquiteto, desenhista, gravurista, artista gráfico, pintor, aquarelista e professor. Formado pela Faculdade de Arquitetura da Universidade Mackenzie em 1954, fez curso de arte com Vicente Mecozzi, Pedro Corona, João Rossi e Waldemar da

\footnotetext{
${ }^{120}$ Segawa, Hugo. Arquiteturas no Brasil 1900-1990. Edusp, São Paulo, 1999, pg. 144.
} 
Costa. Em 1956 muda-se para Salvador e estuda gravura com M ario Cravo Júnior na Escola de Belas Artes da Universidade da Bahia.

Na década de 60, participa dos movimentos de vanguarda, integra 0 grupo dos cinco arquitetos-pintores com Maurício Nogueira Lima, Flávio Império, Sérgio Ferro e Samuel Szpigel e inicia carreira como professor, onde leciona na Faculdade de Arquitetura da Universidade Mackenzie e na Faap, entre outras instituições. Até meados da década de 70 desenvolveu intensa atividade na área de arquitetura.

"Era um artista talentosíssimo, com muita visão da forma e do espaço. Fazia desenhos de perspectiva lindíssimos. Certamente, exerceu influência determinante sobre o trabalho de Zenon Lotufo.

Não sei como teria acontecido o contato entre ambos, mas sei que um complementava o trabalho do outro. Zenon era mais metódico e organizado enquanto Bira tinha um talento artístico para a forma. Era um artista de atelier". ${ }^{121}$

Entre seus prêmios destacam-se: Prix de Voyage (1955 pela M aison de France, tornando-se bolsista do Governo Frances em 1960), Medalha de ouro no XIII SPAM em 1965, Primeiro Prêmio Pintura e Primeiro prêmio Desenho nos Io e IIo Salão de Arte de S. Caetano do Sul/SP, M elhor Gravador em 77 e Prêmio Vencedor de vários Concursos Nacionais de

${ }^{121}$ Depoimento de Walter Maffei em 30 de outubro de 2007. Maffei foi sócio de Ubirajara Ribeiro de 64 a 74.
Arquitetura: Associação Atlética Banco do Brasil em Porto Alegre, Mercado M unicipal de Porto Alegre, Sindicato dos Trabalhadores nas Indústrias de Energia Elétrica de SP, Catedral Presbiteriana de Brasília, Praça M unicipal de Esporte em S. Caetano do Sul/SP, Quartel do Exército no Parque Ibirapuera, projetou o Teatro Castro Alves em Salvador com equipe de arquitetos.

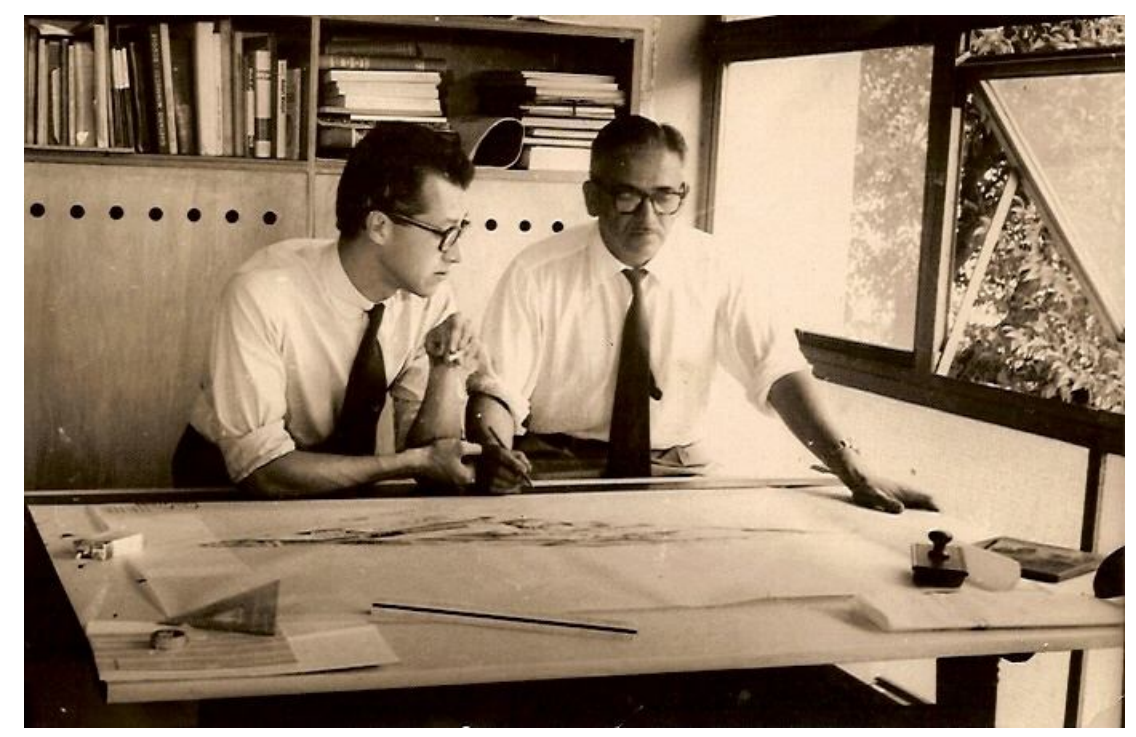

(Fig. 139) Foto de Zenon Lotufo e Ubirajara Ribeiro no escritório na Rua Major Sertório. Fonte: Arquivo da família Lotufo. 


\subsection{Principais obras e projetos realizados pelos arquitetos}

Associação Atlética do Banco do Brasil (Porto Alegre/ RS, 1958)

(Não Construído - Concurso público nacional - $1^{\circ}$. lugar)

Projeto: Zenon Lotufo / Ubirajara M otta Lima Ribeiro.

Fonte: M ódulo 4, ago 60, pp- 40-45.
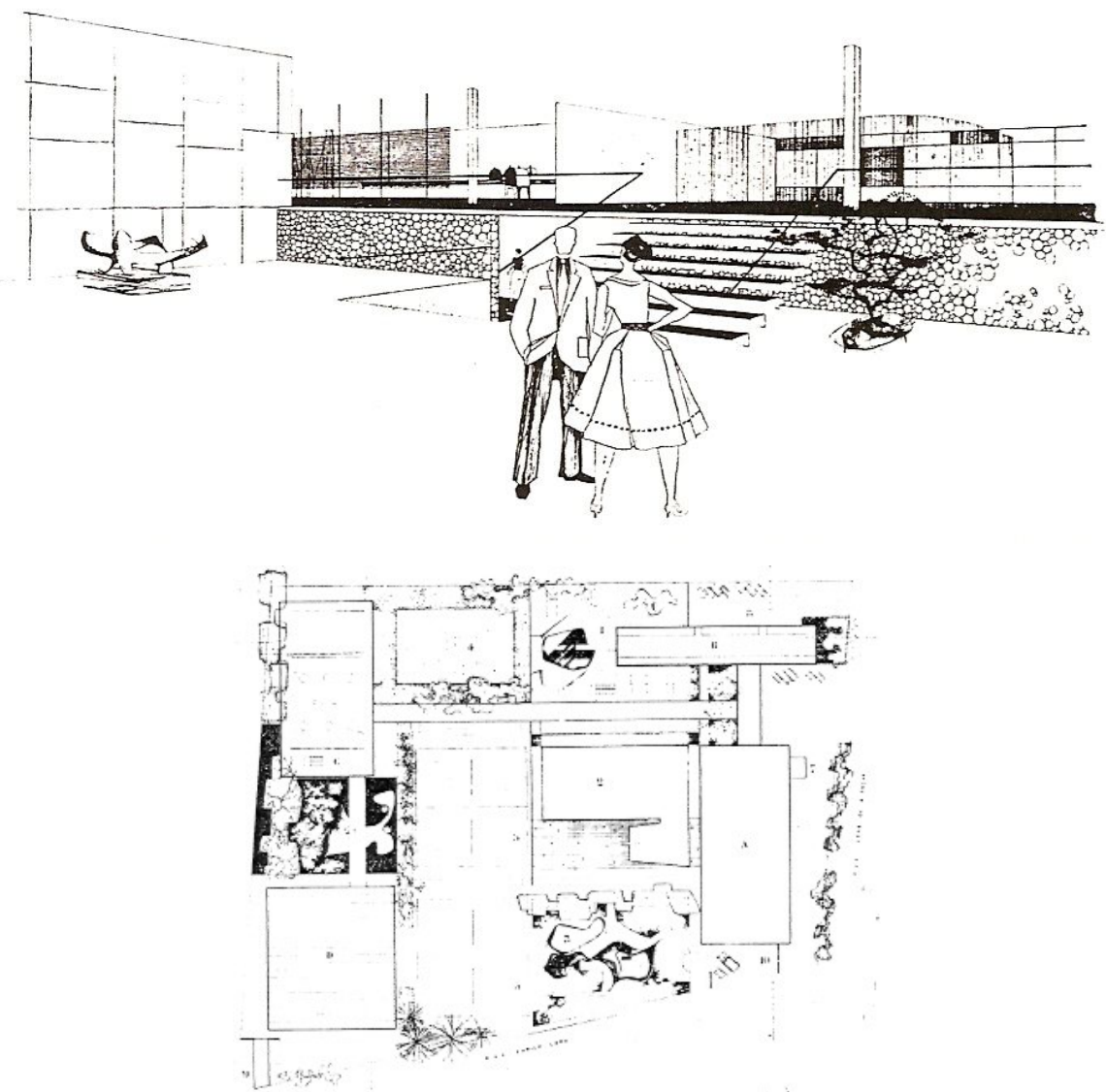

(Figs. 140-141) Perspectiva e Implantação.
Este anteprojeto vencedor de concurso nacional para sede social e esportiva da Associação Atlética do Banco do Brasil em Porto Alegre inicia uma nova fase na carreira de Zenon Lotufo, onde prevalece maturidade e ao mesmo tempo uma maior simplicidade e clareza estrutural. Sua parceria com o arquiteto e artista plástico Ubirajara Ribeiro seria fruto de outros sucessos em demais concursos. Neste concurso, os arquitetos agruparam as atividades segundo afinidades programáticas o que permitiu a criação de ambientes variados com a preocupação de oferecer maior contato social, onde o aproveitamento da topografia do terreno também foi fator decisivo para o sucesso do projeto.

Programa: Sede social: Salão / Restaurante / Administração / Vestiários; Alojamentos: Apartamentos / Dormitórios / Lavanderia; Ginásio: Quadra poliesportiva coberta / Vestiários / Oficinas; Play-ground: Quadras de tênis; Jardim; Boliche-bocha.

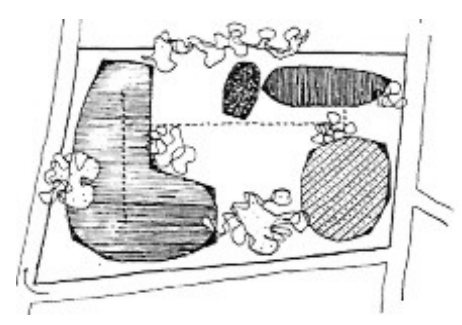

Esquema - circulação

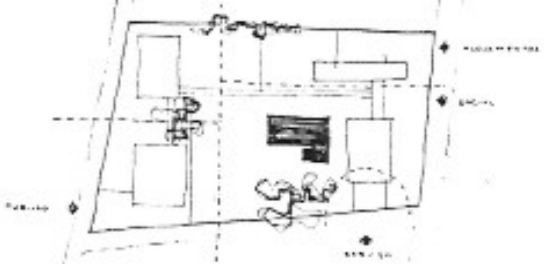

Esquema - zoneamento

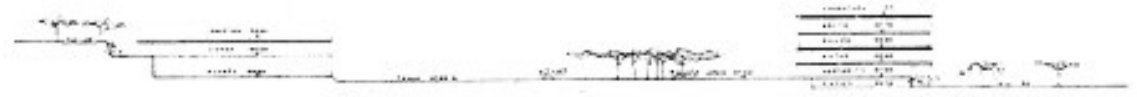

Corte esquemático 


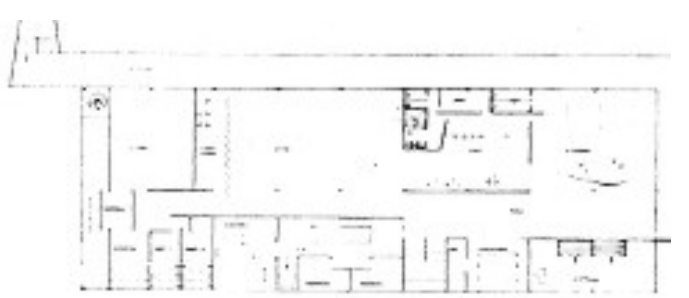

Planta Térreo - Sede social

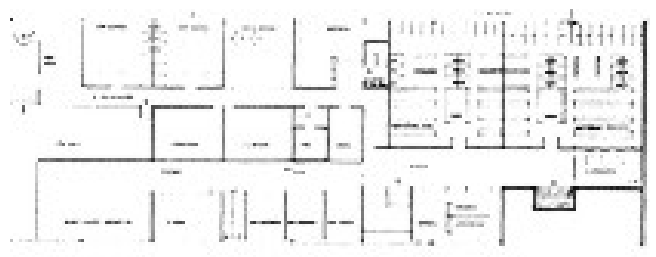

Planta $1^{\circ}$ pavimento - Sede social

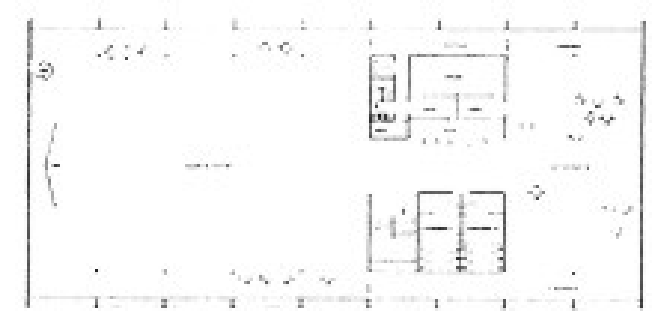

Planta $2^{\circ}$. pavimento -Sede social

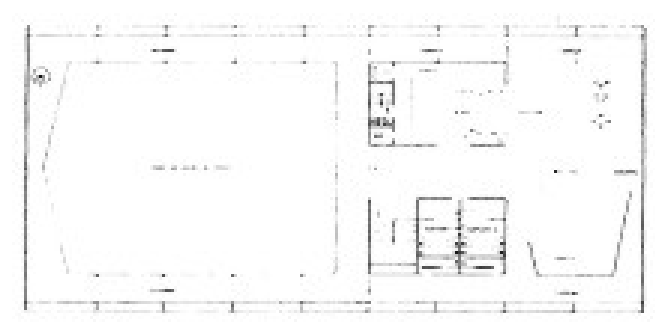

Planta $3^{\circ}$. pavimento - Sede social

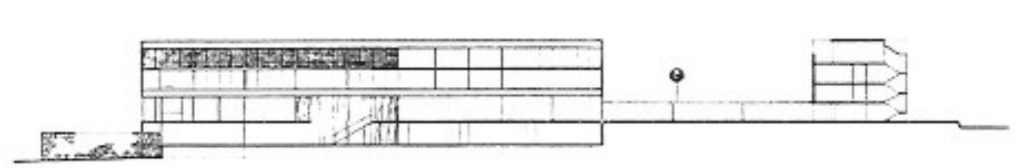

Corte Sede social e Alojamentos

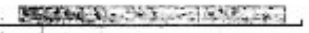

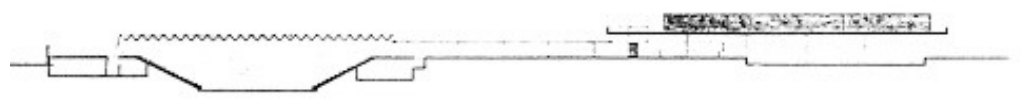

Corte Ginásio

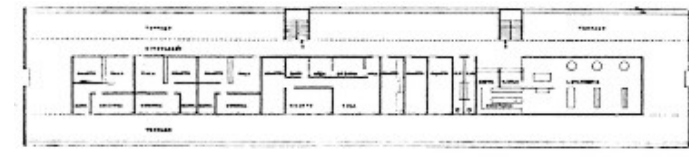

Planta Cobertura
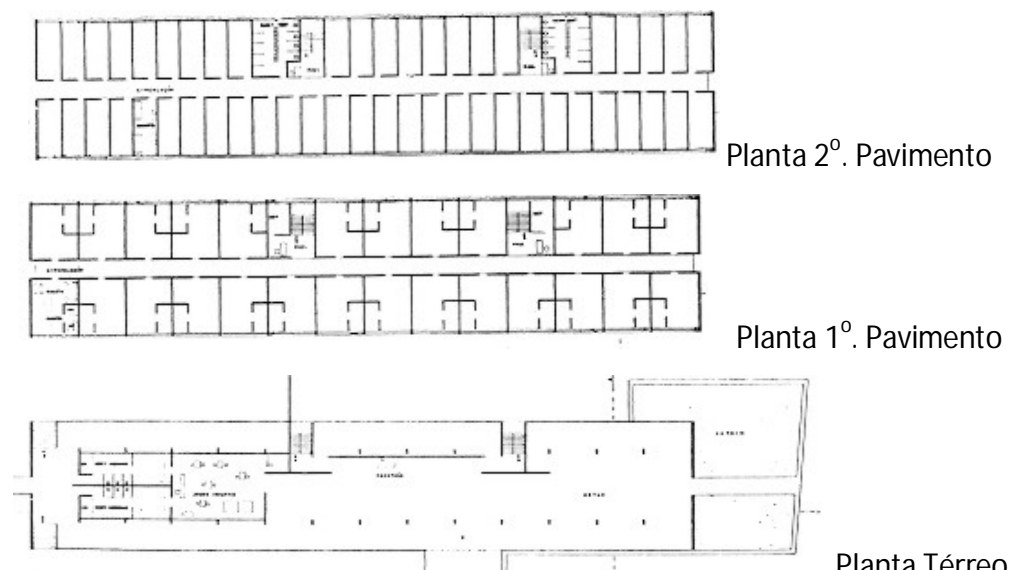

Planta Térreo

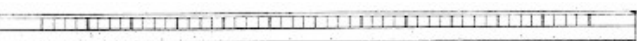

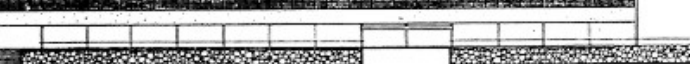

Elevação - Alojamentos

(Figs. 142-155) 
Anteprojeto para Praça de Esportes (São Caetano do Sul/ SP, 1960 - Não Construído)

Projeto: Zenon Lotufo / Ubirajara M otta Lima Ribeiro (Concurso público nacional - $1^{0}$. lugar) Fonte: Acrópole 264, out 60, pp-354-357.

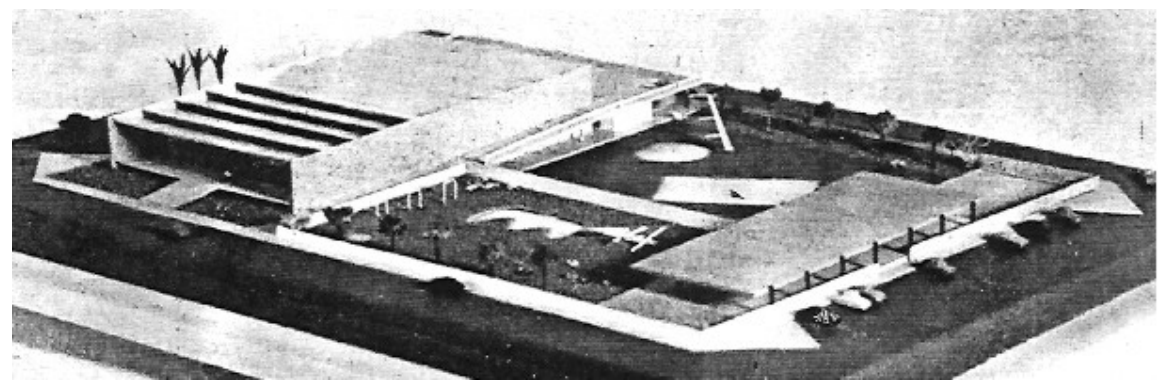

(Fig. 156) Foto maquete.

Concurso realizado pela Prefeitura M unicipal de São Caetano para uma praça de atividades esportivas situado em quadra entre as ruas Tapajós, Goiás, Capiberibe e Conselheiro Lafayete. 0 bom aproveitamento do terreno levou a uma ocupação racional do mesmo, onde o ginásio situa-se no sentido transversal. Uma larga esplanada faz a conexão entre as demais atividades como vestiários, piscinas e playground. Duas paredes laterais sustentam a cobertura em "shed" do ginásio permitindo a iluminação natural. 0 desnível natural do terreno foi aproveitado de modo a minimizar os trabalhos de terraplanagem e criar as arquibancadas do ginásio e das piscinas.

Programa: Ginásio coberto / Vestiários / Bocha / Galpão / Play-ground / Piscinas / Ginástica / Estacionamentos.

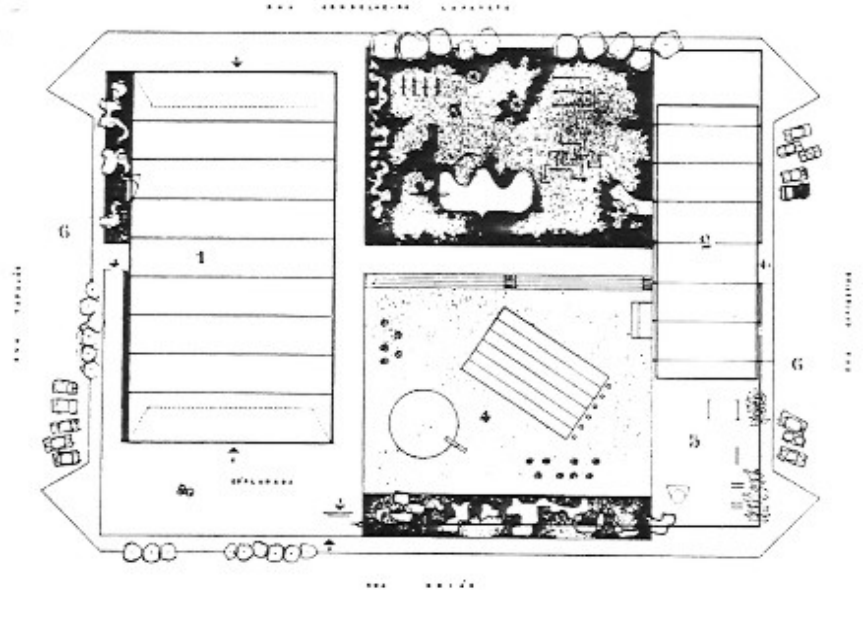

Implantação
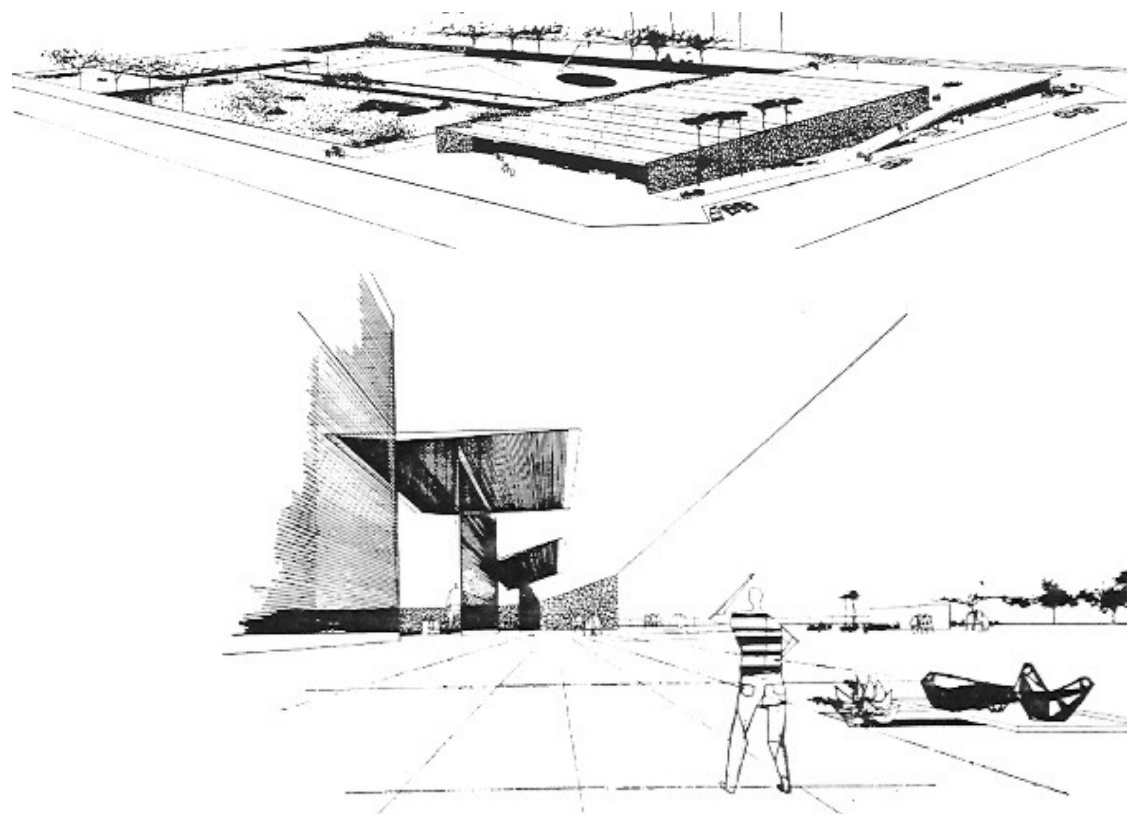

Perspectiva - esplanada 

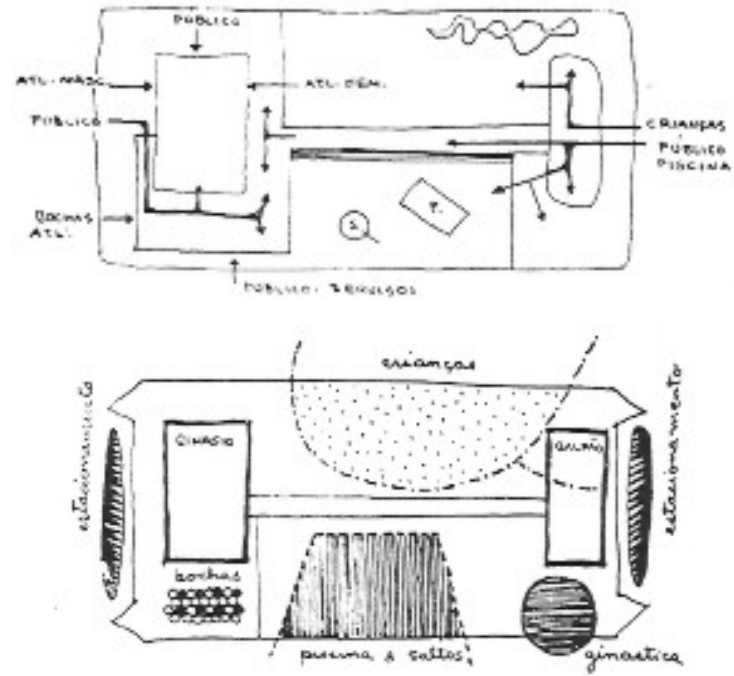

Esquemas - Circulação e Zoneamento
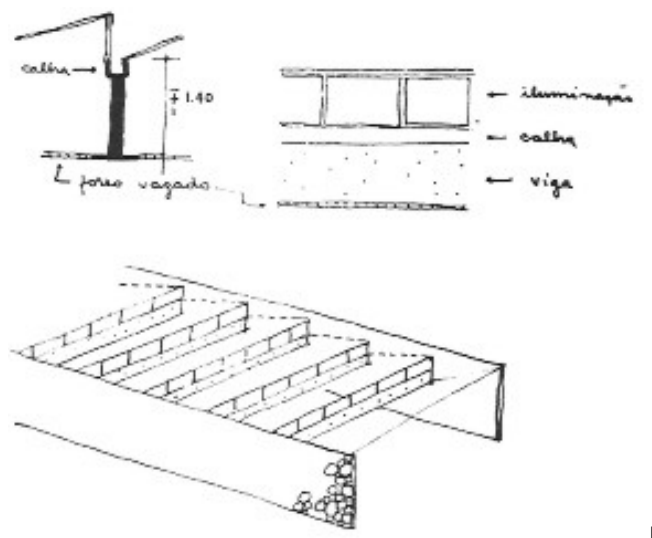

Esquema cobertura - Ginásio

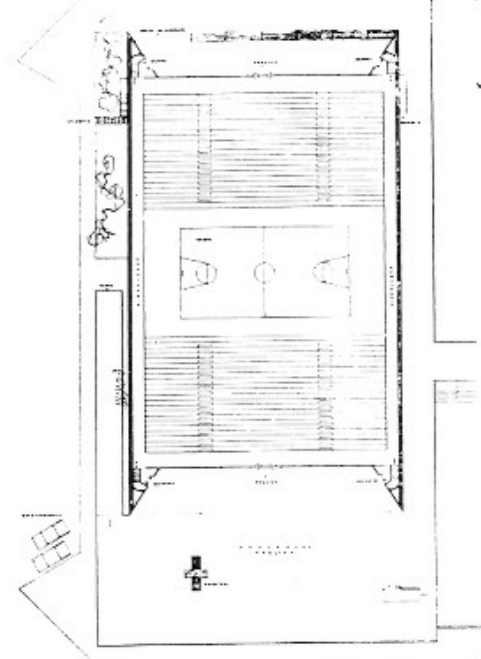

Planta Superior - Ginásio

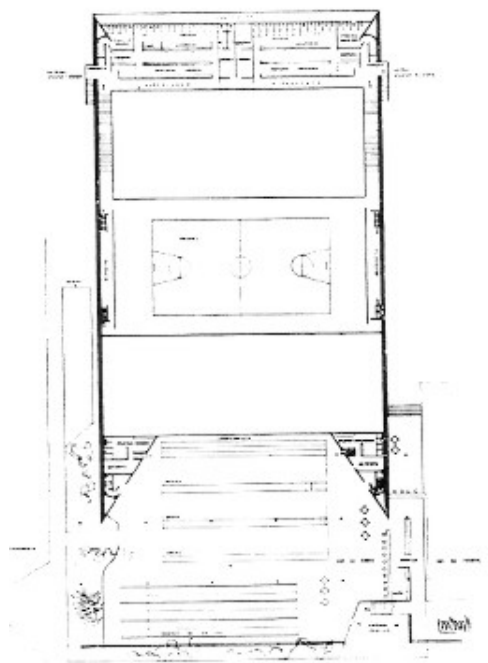

Planta Inferior - Ginásio
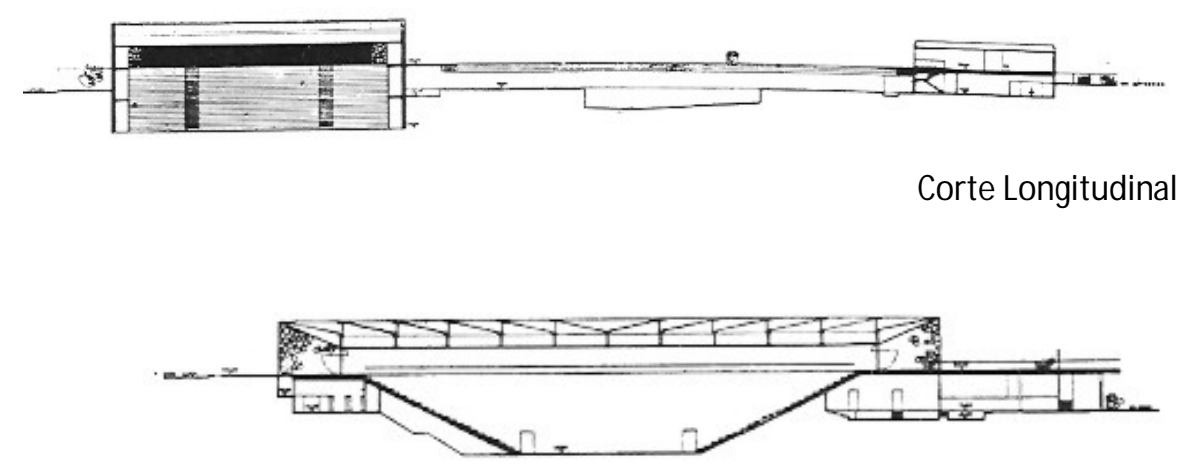

Corte - Ginásio

(Figs. 157-166) 


\section{Anteprojeto para Supermercado (São Paulo/SP, 1961 - Não Construído)}

Projeto: Zenon Lotufo / Ubirajara Motta Lima Ribeiro

(Fonte: Acrópole 269, mar 61, pp-182-184).

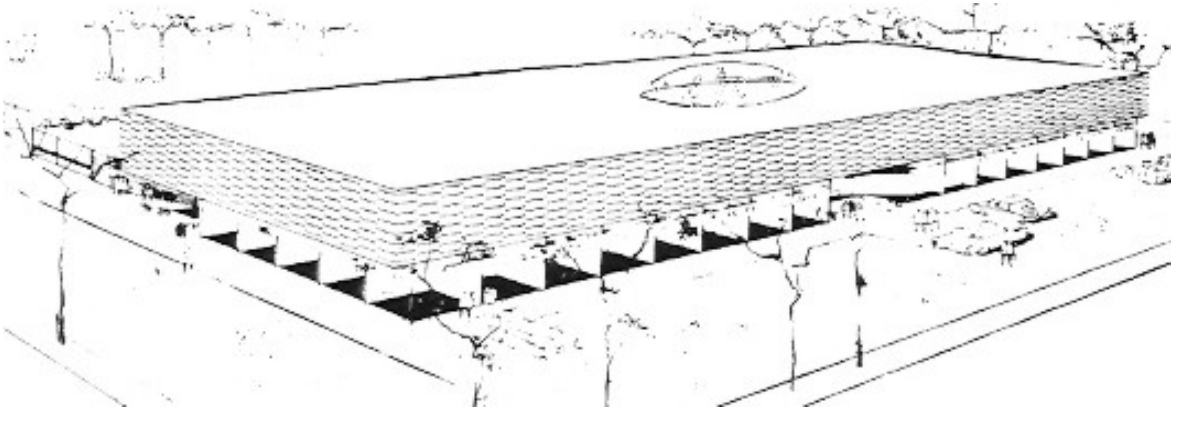

(Fig. 167)

Projeto de mercado que atenta para a questão das circulações das mercadorias e dos serviços. Pensado de forma a garantir uma independência entre o acesso do público que trafega em amplo hall e rampa circular central que liga o nível superior. Solução estrutural em concreto armado sendo as lajes nervuradas em caixão perdido. Um grande e redondo "domus" transparente permitiria a iluminação natural na parte central do edifício sendo que todas as faces laterais do piso superior apresentariam brises solares, o que eliminava a necessidade de esquadrias e vidros.
Programa: Térreo: Estacionamento / Acesso ao público / Hall / Rampa Circular / Boxes e bancas / Banheiros / Depósitos; Piso intermediário (mezzanino): Bar / Charutaria / Banca de jornais e revistas / Correio / Bomboniere / Acesso de mercadorias; Superior: Bancas / Banheiros / Depósitos.

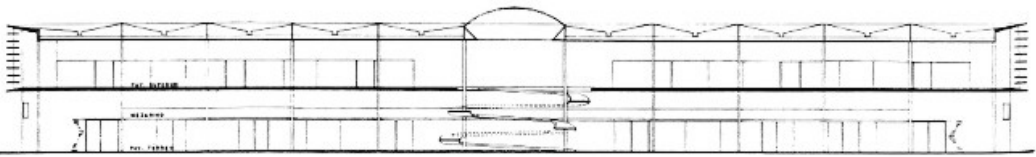

Corte longitudinal

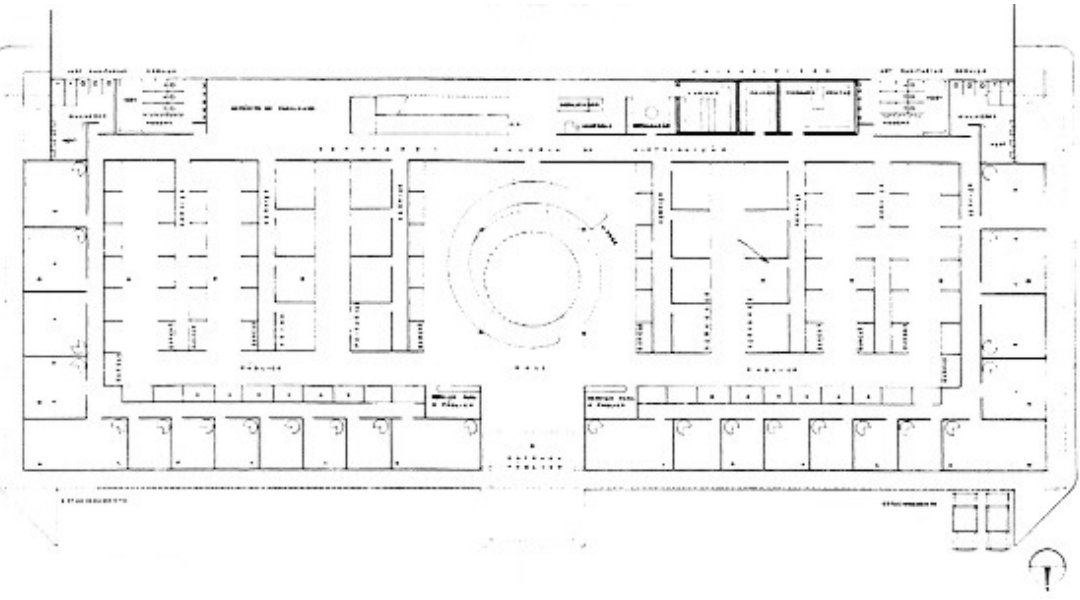

Planta - Térreo 


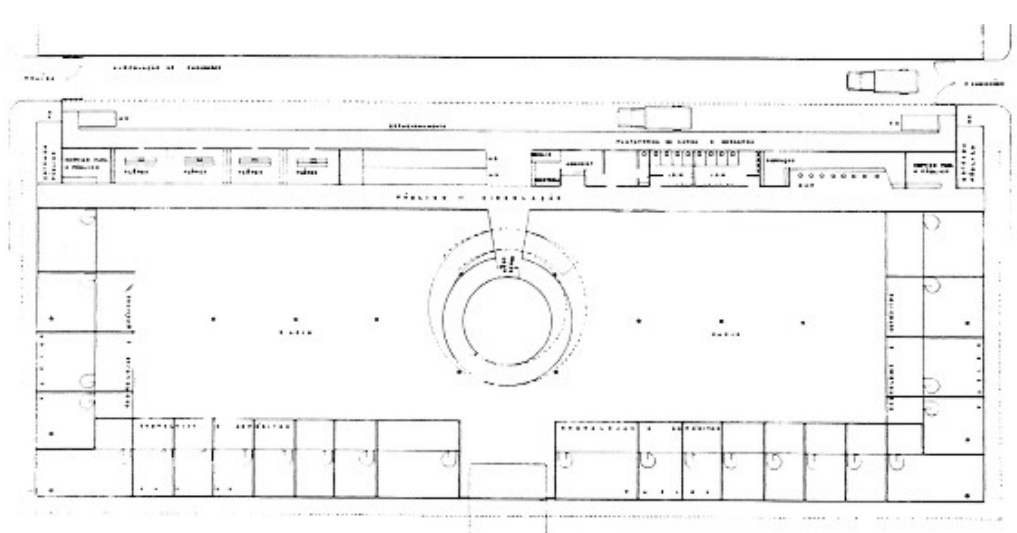

Planta - Mezzanino

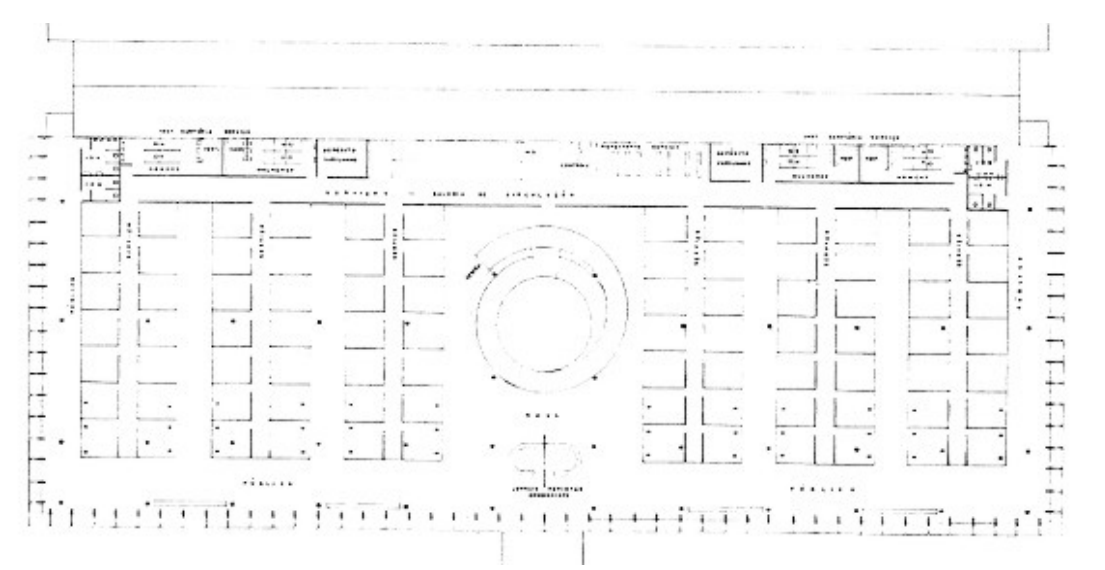

Planta - Superior

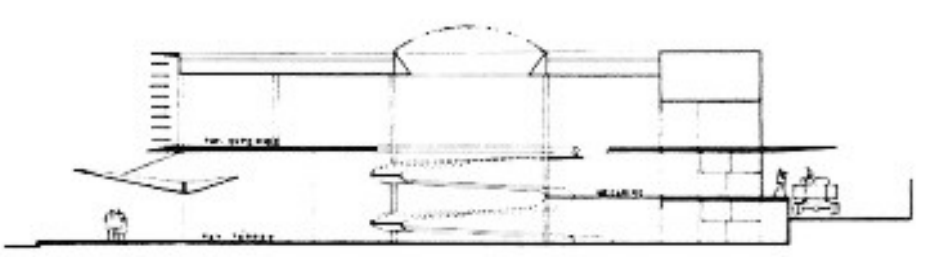

Corte transversal (figs. 168-172).

\section{Departamento de Eletricidade da Politécnica (São Paulo/SP, 1961-66 -}

Construído)

Projeto: Zenon Lotufo / Ubirajara Motta Lima Ribeiro.

Construção: Escritório Técnico da C.U.A.S.O.

Fonte: Revista Acrópole 327, abr 66, pp-40-43.

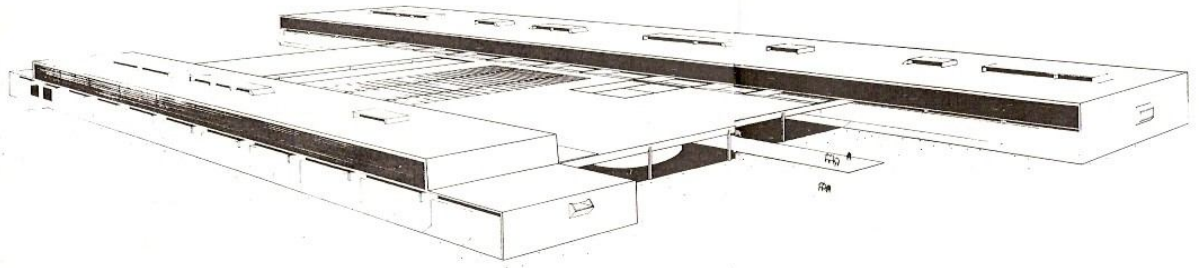

(Fig. 173) Perspectiva externa.

Situado na Cidade Universitária, este projeto consta de blocos de salas de aulas e laboratórios destinados à pesquisa da energia elétrica ligada a Escola Politécnica da Universidade de São Paulo. A solução explora a horizontalidade do edifício com amplos espaços abertos (pátios) para iluminação e ventilação natural além de serem espaços bastante significativos para a troca de informações entre os colegas e professores. Programa: Térreo: Estacionamento / Hall de acesso / Auditório / Administração / Biblioteca / Laboratórios / Oficinas / Sala de máquinas / Sanitários. Superior: Terraço-café / Salas de aula Laboratórios / Sala professores / Sanitários. 


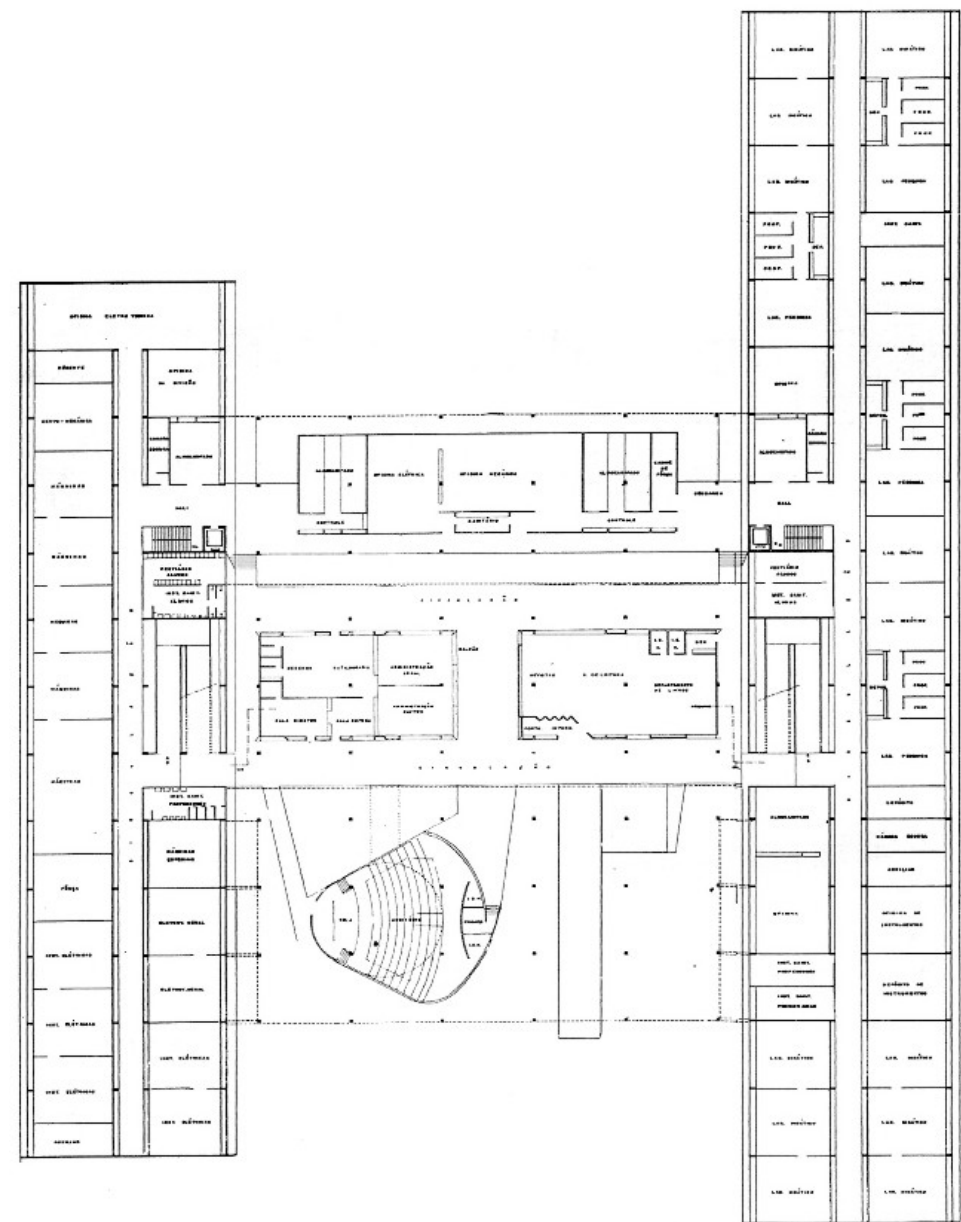

Planta Térreo

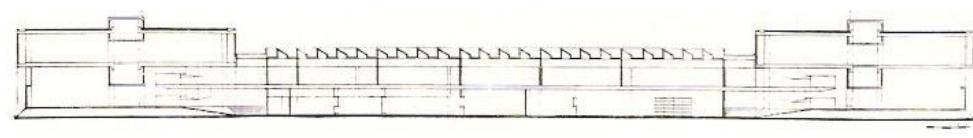

Corte transversal

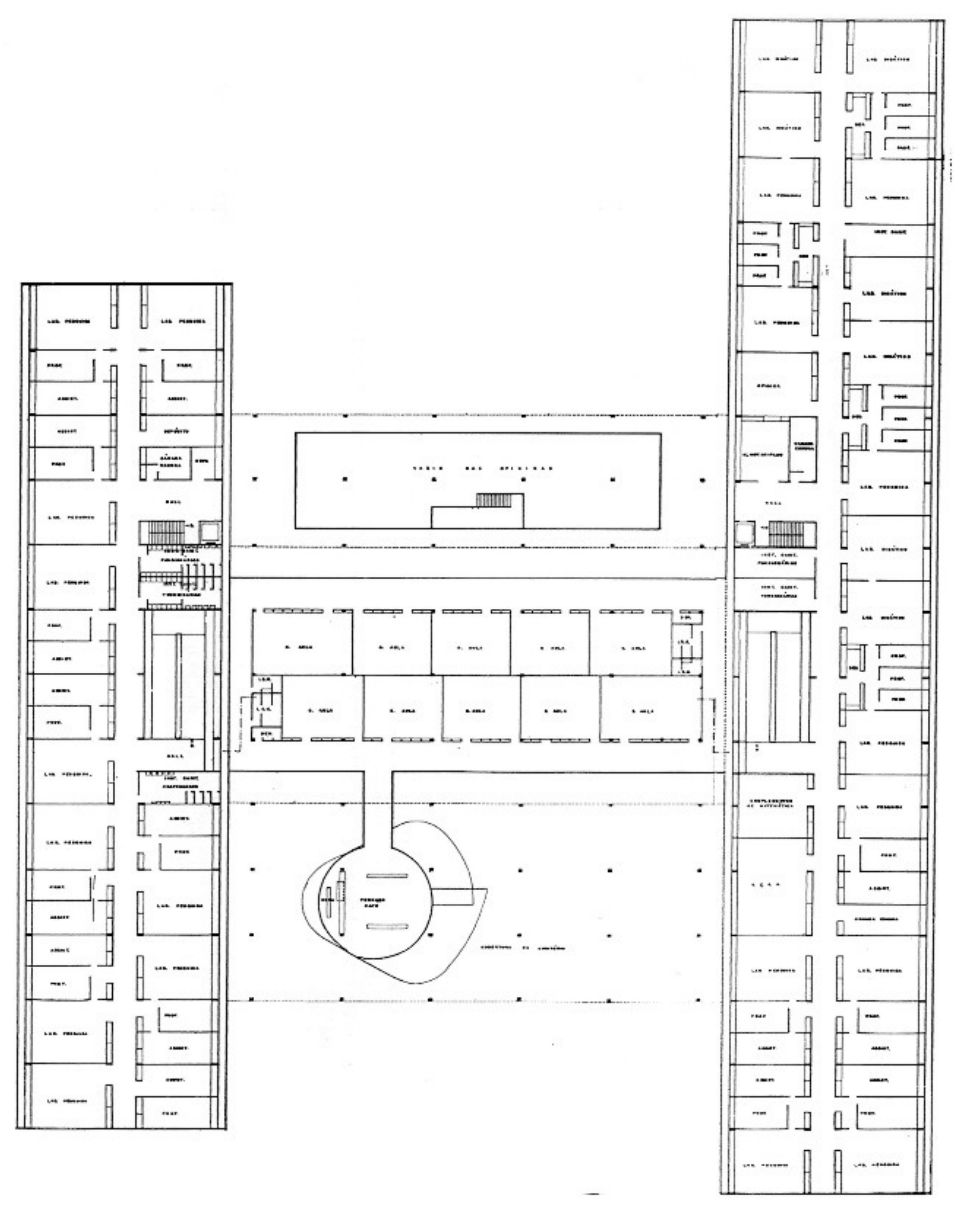

Planta Superior

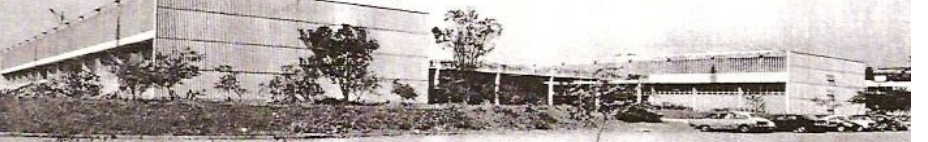

(figs. 174-177) 
Sede do Sindicato dos Trabalhadores de Energia Elétrica (São Paulo/SP,

1963 - Construído - Concurso público nacional - $1^{0}$. lugar)

Projeto: Zenon Lotufo / Ubirajara M otta Lima Ribeiro.

Engenheiro: Roberto Zuccolo

Fonte: Acrópole 298, ago 63, pp- 295-297.
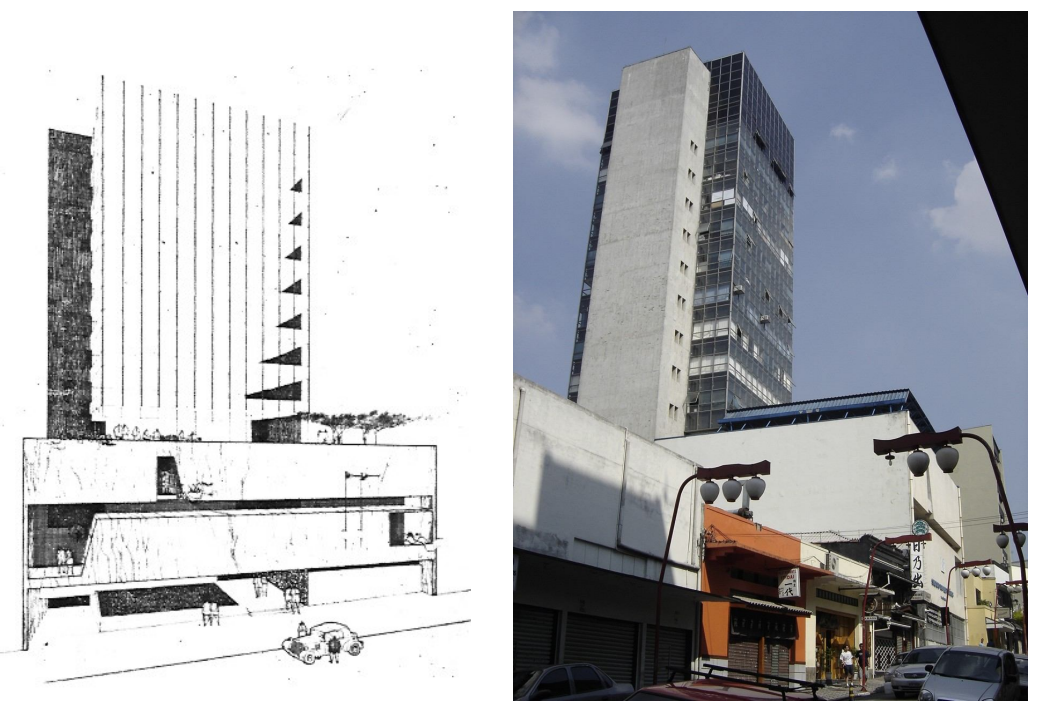

(Figs. 178-179) Ilustração e foto recente. Fonte: EM F.

Concurso público nacional cujo assessor foi o arquiteto Eduardo Kneese de M ello e a comissão julgadora formada por: Rino Levi, Leo Ribeiro de Moraes, Octavio Lotufo, Décio G. Pereira e M ário Savelli. Foi atribuído o primeiro prêmio aos arquitetos Zenon Lotufo e Ubirajara Ribeiro sendo que a comissão destacou: "ótima disposição do salão de festas e do auditório em relação ao acesso da rua, possibilitando o uso independente entre si e os demais ambientes do edifício. Dois sistemas de circulação verticais autônomos - uma para serviços e outra social. Boa distribuição e agrupamento funcional das dependências, todos dotados de ótima iluminação e ventilação. Estrutura em harmonia com o partido arquitetônico."

Um dos primeiros prédios paulistanos a utilizar a tecnologia do concreto protendido. A estrutura do edifício reduzia-se às vigas e às lajes gerando economia na construção e dois grandes blocos laterais de circulação vertical faziam toda a sustentação do prédio. Programa: $\mathbf{2}^{\circ}$.subsolo: Garagem estacionamento; $\mathbf{1}^{\circ}$. Subsolo: Auditório; Mezzanino: Bar / Restaurante; Térreo: Entrada / Hall nobre / Exposições; $1^{0}$ Pavimento: Salão de festas; $4^{\circ}$. ao $\mathbf{1 2}^{\circ}$. Pavimento: Escritórios.

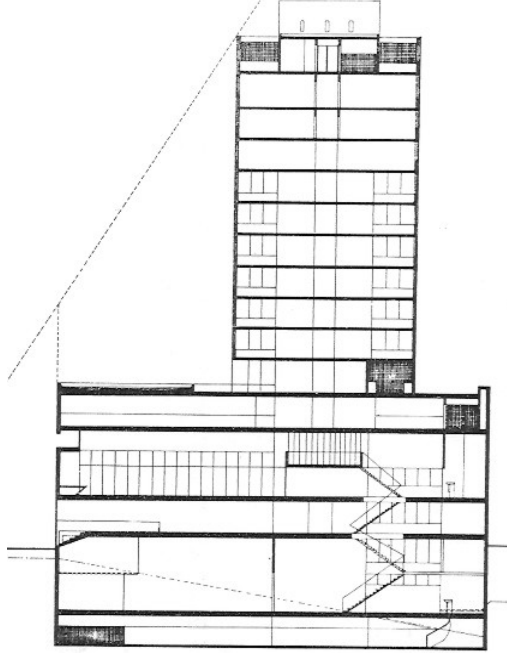

Corte

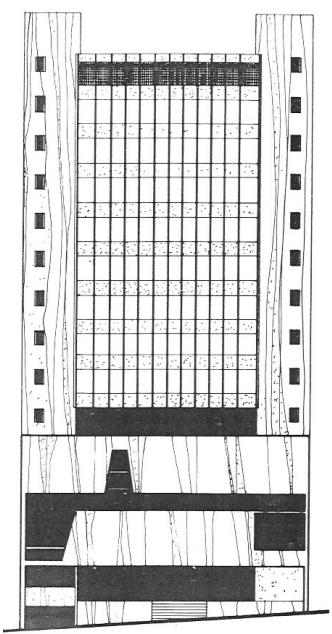

Fachada 


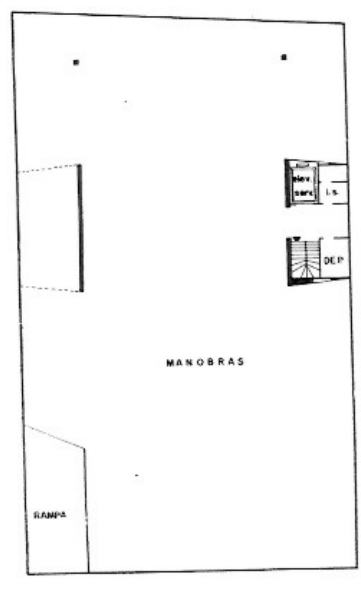

Planta - Estacionamento

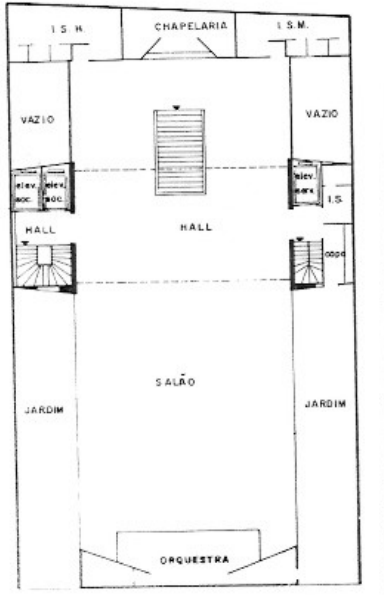

Planta - Salão Festas

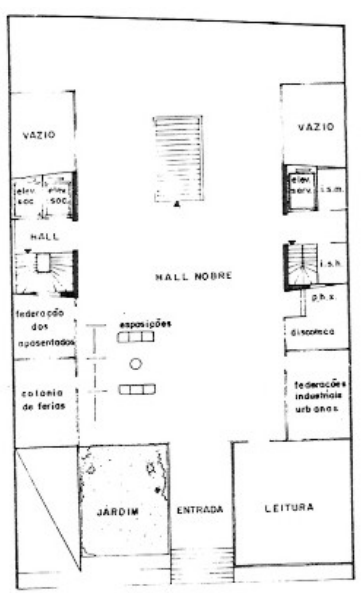

Planta - Hall Entrada

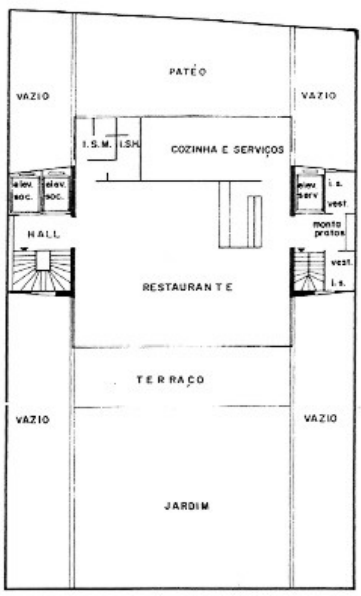

Planta - Restaurante

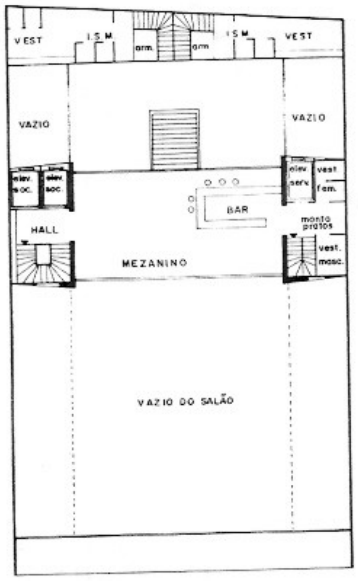

Planta- M ezanino

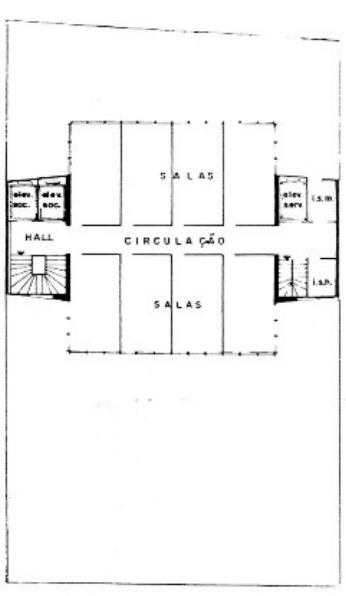

Planta - Escritórios (Figs. 180-187)
Estádio Municipal “Annacleto Campanella” (São Caetano do Sul/SP, 1965 - Construído)

Projeto: Zenon Lotufo / Ubirajara M otta Lima Ribeiro.

Construção: Heleno e Fonseca S.A.

(Fonte: Acrópole 316, abr 65, pp-26-29).

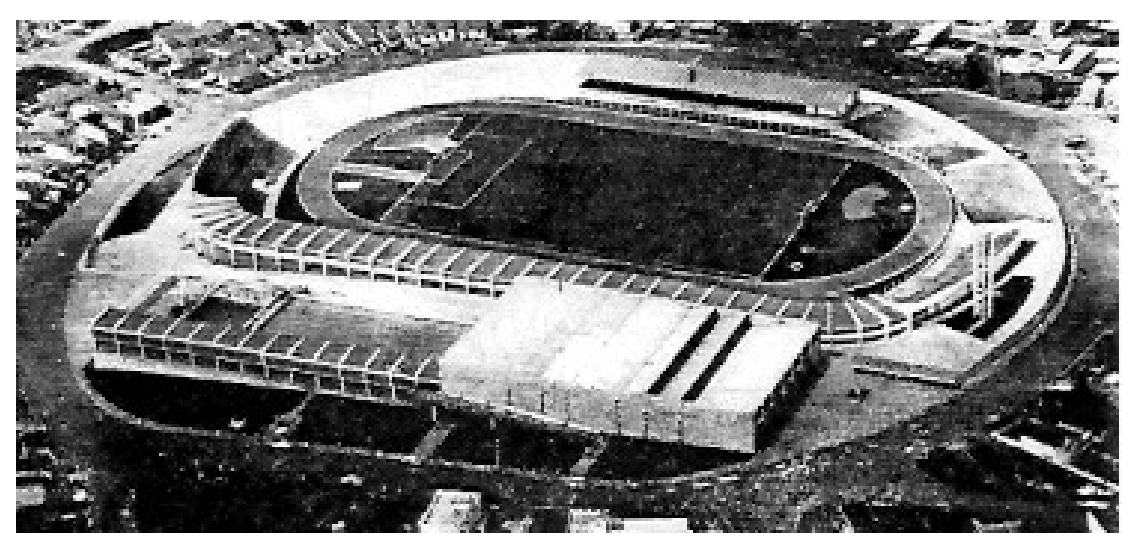

(Fig. 188) Foto aérea.

Os arquitetos haviam vencido anteriormente 0 concurso para a praça de esportes, mas a Prefeitura M unicipal mudou a decisão e optou pela remodelação da antiga praça de esportes do São Caetano Futebol Clube, que na época contava apenas com o campo de futebol. No projeto para o ginásio foi aproveitado a mesma solução estrutural do projeto anterior: duas paredes estruturais de apoio para a cobertura metálica em "sheds". Programa: Ginásio poli-esportivo / Piscina olímpica / Piscina de saltos / Arquibancadas / Bilheteria. 

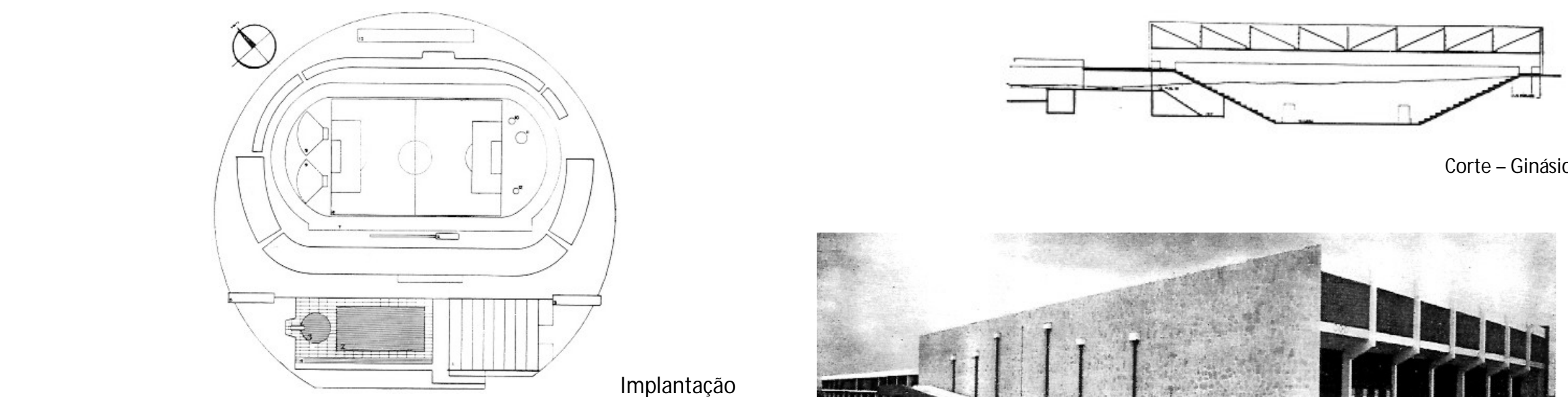

Corte - Ginásio

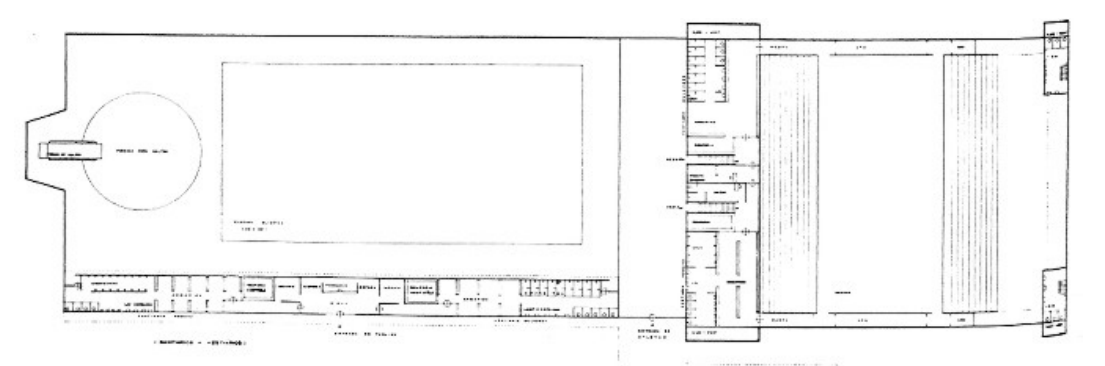

Planta Inferior - Piscinas e Ginásio (Vestiários)
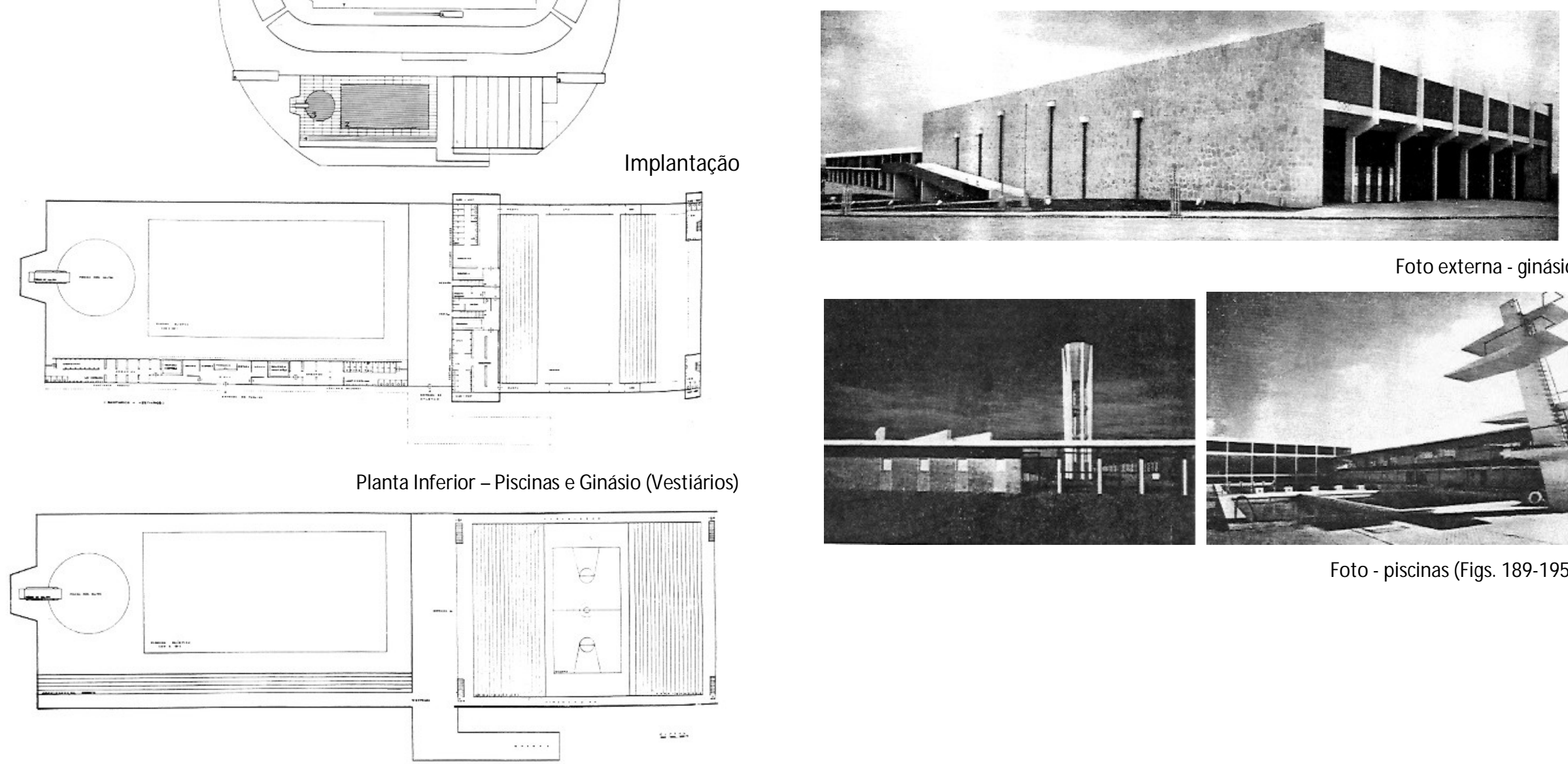

Foto externa - ginásio
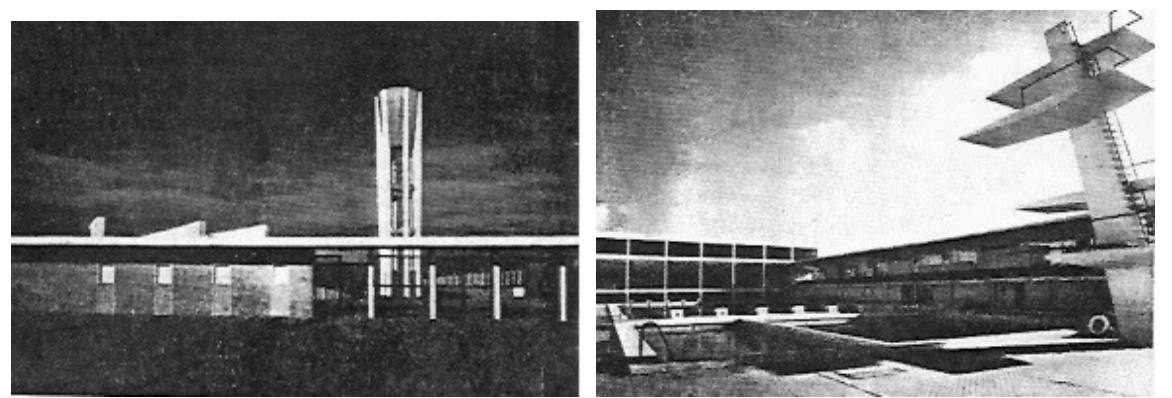

Foto - piscinas (Figs. 189-195)

Planta Superior (Arquibancadas) 


\subsection{Arte ou artifício e a volta ao ensino (66)}

Permanecendo quase dez anos praticamente afastado do meio

acadêmico, Zenon Lotufo (com 55 anos) voltaria a escrever a tese de

titulo "Arte ou Artifício" apresentada no concurso de cátedra da cadeira

n. 12 "Construções de Edifícios; Noções de Arquitetura, Engenharia

Urbana e Urbanismo", no curso de Engenharia Civil da Escola Politécnica da Universidade de São Paulo em dezembro de 1966 (portanto 30 anos depois de sua formatura na mesma Escola).

Seu texto contendo sempre uma linguagem simples e didática mostrava um panorama histórico da relação forma-estrutura na evolução da arquitetura iniciando com uma discussão sobre o significado de palavras como estrutura, forma e ordem.

“Estrutura sugere a idéia de organização, composição de coisas, relação entre partes de um todo, constituindo uma forma. Produzir uma boa forma estará sempre próximo da criação estética, quanto mais se aproximar da verdade e das leis da boa forma, isto é, quanto melhor organizar os elementos de sua estrutura". ${ }^{122}$

${ }^{122}$ Lotufo, Zenon. Arte ou artifício. Tese apresentada a Congregação da Escola Politécnica da Universidade de São Paulo, 1966, p-2.

\section{A parte e o todo}

Nesta primeira parte, Lotufo citou os trabalhos de Von Ehrenfels sobre a teoria da Gestalt (Gestalttheorie) e o livro Psychologie de la Forme de Paul Guillaume onde descreveu que a noção de unidade percebida pela visão humana dava-se pela maneira como as partes deste sistema (todo) se relacionavam.

Se entendermos o exemplo de uma melodia musical que é composta por diferentes sons e timbres relacionados entre si conformando a estrutura de uma canção. Ou o mesmo poderia se dizer de um quadro composto de figuras que são pontos e linhas organizados.

Se alguma mudança ocorre nas condições de um elemento, o todo já não mais se comportará da mesma forma. Tornar-se-á, portanto uma nova relação, uma nova forma. Segundo Lotufo, não existiria em uma obra de arte, menos ou mais importante, apenas a idéia de todo, de sistema.

Portanto, podemos entender que a relação entre as partes é determinante na configuração do todo, e assim, discutir se uma parte é ou não apropriada ou conveniente, mas o sentido de totalidade sempre será alterado se algo for remanejado, seja numa melodia, numa figura ou em um edifício. Zenon posteriormente esclareceria que o principal objetivo da engenharia era a realização da estrutura mais elementar e eficiente possível, com o mínimo gasto de energia e de material. 


\section{Percepção do todo}

A noção de profundidade e proximidade de um objeto ou edifício estaria determinada por fenômenos óticos captados por nossos olhos e transformada em imagens. Assim nosso aparelho ótico tenderia a corrigir deformações procurando ajustar em nossa mente uma imagem que lhe pareça satisfatório.

As experiências realizadas pela psicologia da Gestalt no princípio do século XX foram a fundo nestas questões, e o que se concluiu é que tendemos sempre a buscar uma relação de unidade e de conjunto nos objetos que nos cercam.

A tese fundamental da teoria da Gestalt evidenciava a percepção como dado original. 0 estudo da percepção então passa a ser a tônica dos trabalhos de Wertheimer que em 1912 afirmou que há contextos em que o que acontece no todo não pode ser deduzido das características das partes separadas, mas inversamente, o que acontece a uma parte do todo, é determinado, em casos bem nítidos, pelas leis da estrutura intrínseca do seu todo.

Assim, todas as funções psicológicas como memória, percepção, inteligência e emoção foram compreendidas através dos princípios fundamentais da psicologia da forma que foram expressos da seguinte maneira:
- Lei da boa forma ou princípio da pregnância: é a tendência que cada estrutura possui de se organizar psicologicamente da melhor forma possível, de acordo com as condições do momento. Abrangendo assim algumas variações como continuidade, simetria, fechamento, direção, proximidade e semelhança.

"Em um conjunto estruturado, a lei do todo determina as partes; estas tendem a se completarem de certo modo a constituir a melhor forma possível". ${ }^{123}$

\section{A estrutura - forma, números e proporções}

Zenon também compartilhou sua opinião sobre a estreita relação entre arte e a matemática, e entre arquitetura e proporção, citando M atila C. Ghika, autor do livro Estética das proporções na Natureza e nas Artes ${ }^{124}$, declarando que toda a harmonia dependia de uma relação geométrica. A seguir, começou a descrever a evolução das estruturas arquitetônicas a partir da relação entre a matemática e as proporções. Um percurso simplificado permeado por ilustrações à mão feitas pelo próprio arquiteto, que iria das pirâmides egípcias, passando pelos templos gregos, aos monumentos romanos, as catedrais góticas, o Renascimento italiano,

\footnotetext{
${ }^{123}$ Idem, p-13.

${ }^{124}$ Ghyka, M. Estética de las Proporciones em la Naturaleza y em las Artes. Ed. Poseidon, Buenos Aires, 1953.
} 
as igrejas Barrocas e concluía nas estruturas industriais da Engenharia moderna.

"A arquitetura egípcia constitui um tratado mudo da geometria. A Grande Pirâmide ofereceu-nos a austeridade do volume com proporções e progressões que se derivam dela. Condensadas sobre si mesmas, algumas construções mais características da morfologia dos cinco corpos platônicos. Sua forma equilibrada, derivada da combinação de forças horizontais com forças verticais é exemplo supremo de uma ordem eterna". ${ }^{125}$
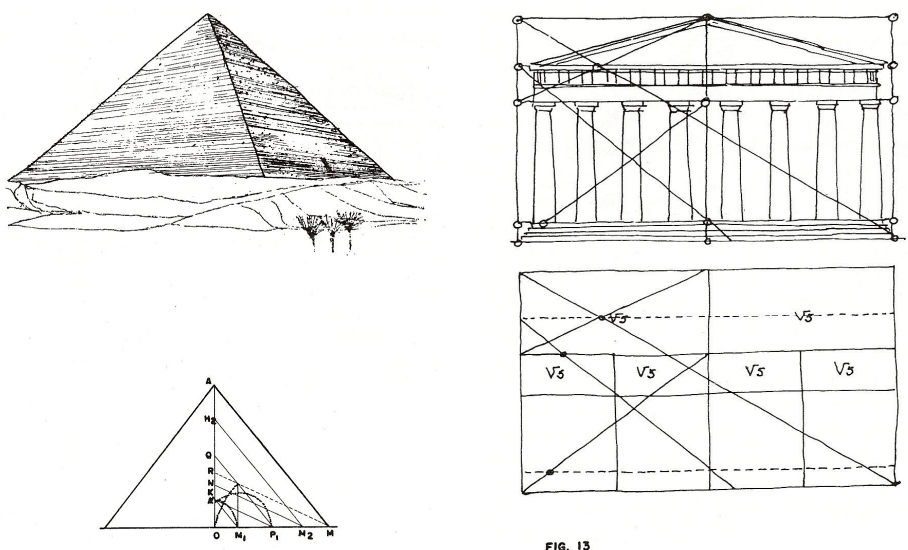

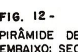

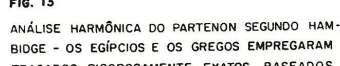

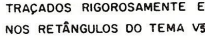

Fig. 196. Desenhos produzidos por Zenon Lotufo. Fonte: Arte ou artificio, pg.37-38.

\footnotetext{
${ }^{125}$ Ibidem, pg. 36.
}

Por sua vez, os templos gregos projetavam exteriormente a claridade das grandes linhas e a sutileza da geometria euclidiana, expressando todo um sistema filosófico onde a harmonia perfeita estava representada na unidade cósmica do Universo.

\section{Arquitetura romana, bizantina e românica}

A arquitetura dos engenheiros romanos produziu formas sinceras e correspondentes às funções específicas dos edifícios. Sua beleza estava no caráter humano e sereno de seus volumes e não mais numa invocação mística.

Em Bizâncio, mais tarde, citava Zenon, a clareza dos volumes geométricos, como o cubo, apareceriam de maneira elementar na composição arquitetônica como na estrutura da Santa Sofia.

"A época românica é um prolongamento da sinceridade Bizantina na expressão dos volumes. 0 prolongamento das naves substitui a simetria demasiada e cristalina do cubo, introduzindo como elemento novo, uma modulação dirigida do espaço e uma sugestão paralela de energia acumulada e retida, porém nela voltamos a encontrar os cilindros, semicilindros, prismas octogonais, calotas esféricas pendentes em límpida geometria de volumes honestos". ${ }^{126}$

\footnotetext{
${ }^{126}$ Ibidem, pg. 40.
} 


\section{0 esplendor gótico}

Citando Le Corbusier, Zenon reproduziu a condição da catedral gótica para o mestre franco-suíço.

"O Gótico, como outros estilos, estão para Arquitetura como a pena no cabelo de uma mulher; são muitas vezes bonitas, e nada mais. Uma catedral nos interessa como engenhosa solução de um problema difícil, mas cujos dados foram mal colocados porque não procedem das grandes formas primárias. A Catedral não é obra plástica; é um drama: uma luta contra a gravidade. A sinceridade, a verdade nos volumes, é substituída pela sinceridade no equilíbrio das forças e dos empuxos. É por essa razão que uma catedral não é muito bela". ${ }^{127}$

Portanto, Zenon compartilhava da mesma opinião de Le Corbusier, pois considerava a arquitetura gótica incomodamente dinâmica e instável. Os volumes ocupavam valor secundário e o que contava era o traçado das linhas de força vetoriais, os empuxos e os esforços distribuídos nos arcobotantes. Para ambos, era a arquitetura da tensão, e não do equilíbrio.

\footnotetext{
${ }^{127}$ Ibdem, pg. 42
}

\section{A época do humanismo na arquitetura}

O Renascimento, segundo Zenon, traria de volta a clareza matemática dos volumes e das proporções para a arte e a arquitetura.

“Guiados por Platão, neoplatônicos e o amparo de uma grande cadeia de teólogos, a partir de Santo Agostinho, alentaram para convicção de que o Universo correspondia a uma estrutura matemática e harmônica. Se as leis dos números harmônicos o regiam, desde as esferas celestiais até as mais humildes da vida terrena; então nossas almas deveriam conformar-se a essa harmonia". ${ }^{128}$

Prosseguindo, Zenon citou o pensamento de Alberti sobre a definição de beleza:

"A beleza consiste em uma integração racional das proporções de todas as partes do edifício, de tal maneira que cada parte tenha um tamanho e uma forma absolutamente fixos, sem que nada se possa acrescentar ou retirar sem destruir a harmonia do todo". ${ }^{129}$

E também, Palladio:

"A beleza resulta da forma bela e da correspondência do todo com as partes, das partes entre si e destas com o todo, de modo tal que as construções pareçam constituir um corpo inteiro e completo, em que cada

\footnotetext{
128 Ibidem, pg. 46.

${ }^{129}$ Ibidem, pg. 47
} 
membro concorda com o outro e todos resultam necessários para a perfeição do edifício". ${ }^{130}$

Zenon relembrava que a fonte dos renascentistas voltava a ser os valores estéticos clássicos (matemática e geometria) da arquitetura grega e romana. E que a geometria do espaço afinal havia sido reformulada recentemente no trabalho de Le Corbusier. Le M odulor seria uma releitura moderna da divina proporção onde o mestre franco-suíço buscou desenvolver uma teoria matemática que respondesse à aplicação prática da geometria clássica nas construções arquitetônicas.

\section{Modulação}

A estética da construção na arquitetura greco-romana ou renascentista decorria principalmente da preocupação com as proporções dos volumes entre si e destes com o conjunto, o todo.

"A Acrópole de Atenas não é o fruto ou o resultado de uma pesquisa plástica de uma geração; é o resultado do trabalho de séculos de uma civilização. Do mesmo modo que a forma das edificações evolui através dos séculos, aprimorando-se as proporções, definindo-se um padrão estético, assim o módulo variou à medida que as colunas foram se adelgando. Mas se a coluna variou de seção e altura foi para atender sempre as possibilidades de resistência do material empregado - mármore ou pedra. Assim, a relação entre diâmetro, altura e entrecolúnio tornou-se necessariamente um fator constante nas edificações antigas, deduzindo daí o modulo da construção. Diferentemente se opera hoje com a coordenação modular, pois além de atender a composição arquitetônica, ela tornou-se um dos mais valiosos auxiliares do construtor, tendo em vista a economia, pela adoção de padrões industrializados ou pré-fabricados que permitem rápida aplicação com menor dispêndio de mão-de-obra, além de apresentar notável flexibilidade no uso do edifício". ${ }^{131}$

Citando Sigfried Giedion, em seu livro Space, Time and Architecture, Zenon também destacou as transformações científicas que marcaram 0 início do século XX, principalmente no diz respeito à noção de tempo. Isto estaria evidenciado pelas correntes artísticas como o cubismo e 0 futurismo, através da introdução do espaço-tempo na linguagem da arte e depois pelas obras dos mestres da arquitetura moderna: Gropius, Le Corbusier, Wright e Neutra.

\section{0 funcionalismo}

Para Zenon, a indústria moderna oferecia agora ao engenheiro um campo ilimitado de aplicação matemática para os cálculos das espessuras das

\footnotetext{
${ }^{131}$ Ibidem, pg. 53 
vértebras de aço, as quais despojadas de todo revestimento se respondiam apenas às reais necessidades estruturais.

Assim, a arquitetura que procurava no século XIX esconder a ossatura do edifício em maciços de alvenaria, começou a redescobrir que o princípio fundamental da organização e da forma era exatamente a estrutura (interessante comparar a sintonia deste discurso com o texto de Por uma Arquitetura, de Le Corbusier).

"Sem perseguir a idéia arquitetural, porém simplesmente guiados pelas necessidades de um programa imperativo, os engenheiros de hoje mostram o novo caminho e criam fatos plásticos, claros e límpidos, dando aos olhos a calma e ao espírito as alegrias da geometria. Escutemos os conselhos dos engenheiros americanos. Porém temamos os arquitetos americanos." 132

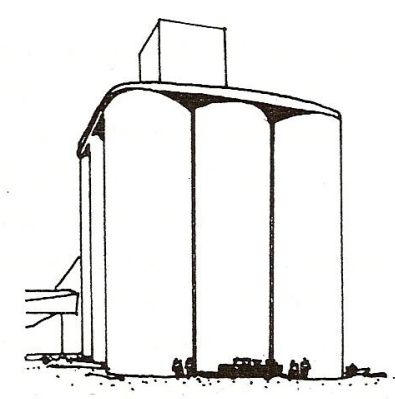

FIG. 210

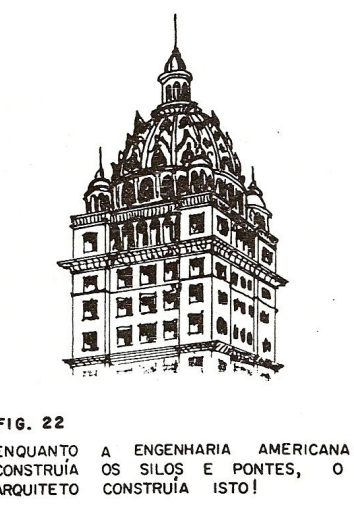

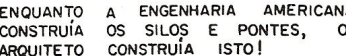

Fig. 197 (desenhos extraídos do ensaio Arte ou artifício, p. 65)

\section{Panorama atual}

O desenvolvimento tecnológico das estruturas no campo da construção estava avançando de maneira muito veloz, segundo Lotufo, mediante muitas pesquisas e realizações. M as o arquiteto fez um alerta destacando que para se tornarem realmente úteis para o homem, as estruturas deveriam obedecer ao menor emprego de material, com mínimo gasto de energia e com máximo de eficiência.

"A evolução da arquitetura ocidental é um encadeamento de transformações e aprimoramentos construtivos determinados por cada época histórica e suas especificas condições sociais, no tempo e no espaço. Foi um processo lento em comparação aos fatos atuais. Antes ao arquiteto era atribuída uma formação artística que era parte integrante de seu desenvolvimento frente à matemática e às técnicas construtivas. Era difícil afirmar se era arquiteto com conhecimento de engenharia ou engenheiro com capacidade artística. Num dado momento, houve um divórcio entre essas disciplinas fundamentais e o bom profissional, passando 0 arquiteto a exercer funções mais ligadas à decoração de edifícios ou desenhista de fachada. Esta situação se alterou com o movimento renovador da arquitetura contemporânea encabeçado por nomes como Lloyd Wright, Gropius e Le Corbusier. E o arquiteto passou a compreender e a empregar os novos processos estruturais rompendo com a tradição acadêmica. Hoje, vivemos um período de velocidade

${ }^{132}$ Ibidem, pg. 63. 
espantosa, onde as coisas são rapidamente superadas, impondo às atividades criadoras além de capacidade artística, outras necessidades e com elas, novos valores. Novos usos pedem novas soluções e subjetivamente o fator "gosto" não segue o mesmo ritmo, mas salta bruscamente desafiando os artistas e arquitetos". ${ }^{133}$

Na conclusão deste importante ensaio, Zenon emprestou a conhecida definição de Lúcio Costa sobre arquitetura, como construção com intenção plástica, fazendo uma sutil distinção entre os trabalhos do engenheiro e do arquiteto.

"O engenheiro, no ato de projetar uma estrutura, embora não seja essa sua preocupação, estará também criando uma forma plástica, quando procurar boas relações entre as partes e destas com o todo. Os conhecimentos adquiridos, a experiência e a intuição atuam conjuntamente na fase de pesquisa da estrutura que proporcione a máxima capacidade com o mínimo de material e menor dispêndio de energia. Por sua vez, o arquiteto, no estudo do projeto, parte da planta, base sobre a qual se levanta a estrutura, os volumes, a forma. Se é bem desenvolvida produzirá formas nobres, variedades de formas e unidade de princípios geométricos. Sem plano não pode haver grandeza de objetivo e expressão, nem ritmo, nem massa, nem coerência. Sem plano temos a

\footnotetext{
133 Ibidem, pg. 67-68.
}

sensação, tão insuportável para o homem, de desordem, de coisa amorfa Forma e estrutura não são independentes. Não há forma em tudo, mas onde há forma, há estrutura". ${ }^{134}$

E finalmente, conferiu nova importância à matemática e à geometria na evolução das estruturas:

"A matemática sempre esteve presente na organização dos planos, geratriz dos volumes geométricos, do grego ao barroco. A lei dos números, os princípios da forma privilegiada e da melhor estrutura prevaleceram. A industrialização dos elementos de construção que atende a coordenação modular está indicando claramente o caminho ao arquiteto e deve orientá-lo na elaboração dos seus trabalhos. Mais uma vez a engenharia e a indústria vão liderar um movimento plástico renovador, que deveria pertencer ao arquiteto, mas que por sua formação distorcida, só mais tarde aceitará o fato de que é possível compor com elementos simples e criar as mais belas formas. A matemática é pura, correta, exata, por isso mesmo a história da arquitetura nos apresenta um repertório de formas belas, simples e corretas pois tiveram estruturas certas, puras e simples. Assim concluímos afirmando que a arquitetura contemporânea, resultado de condições geradas pelas necessidades concretas e subjetivas, determinadas pela evolução social e pela

\footnotetext{
${ }^{134}$ Ibidem, pg. 72-73.
} 
imperativa aplicação de conhecimentos matemáticos da engenharia moderna é válida enquanto seguir a lei da boa forma e da melhor estrutura". ${ }^{135}$

A atenção dada à temática da estrutura revela a sintonia de Zenon com os principais debates teóricos que ocorriam naquele momento, como por exemplo, o Depoimento (58) de Niemeyer.

\subsection{Parceria com o filho: Vitor A. Lotufo (67-72)}

A partir de 67, Zenon passou a contar mais intensamente com a colaboração de seu filho Vitor Amaral Lotufo, recém-formado arquiteto pelo M ackenzie (que já freqüentava o escritório, desde estudante), que havia recebido uma bolsa de estudos na Universidade de Harvard (E.U.A.) , no ano anterior ${ }^{136}$. A parceria rendeu vários e bons trabalhos aos Lotufo, apesar do incômodo quadro político em vigor daqueles anos (ditadura militar, a partir de 64), caracterizados fortemente pela expressão estética marcante da estrutura de concreto aparente, como passamos a mostrar a seguir.

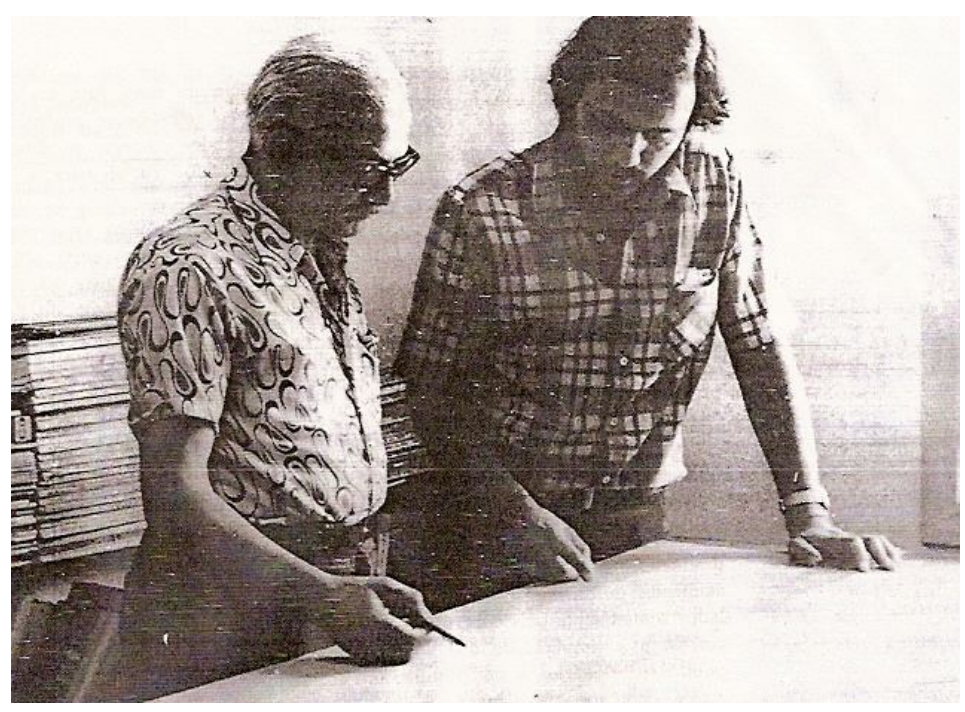

Fig. 198 Zenon e Vitor Lotufo trabalhando. Fonte: Revista AB

\footnotetext{
${ }^{136}$ Revista AB Arquitetura Brasileira n. 8, 1973, pg. 14.
} 


\section{Edifício para Perícias Médicas do I.N.P.S. (São Paulo/SP, 1967 -}

Construído)

Projeto: Zenon Lotufo / Vitor Amaral Lotufo / Victor Pini

Fonte: Arquitetura Brasileira 8 (1974), pp-40-49.
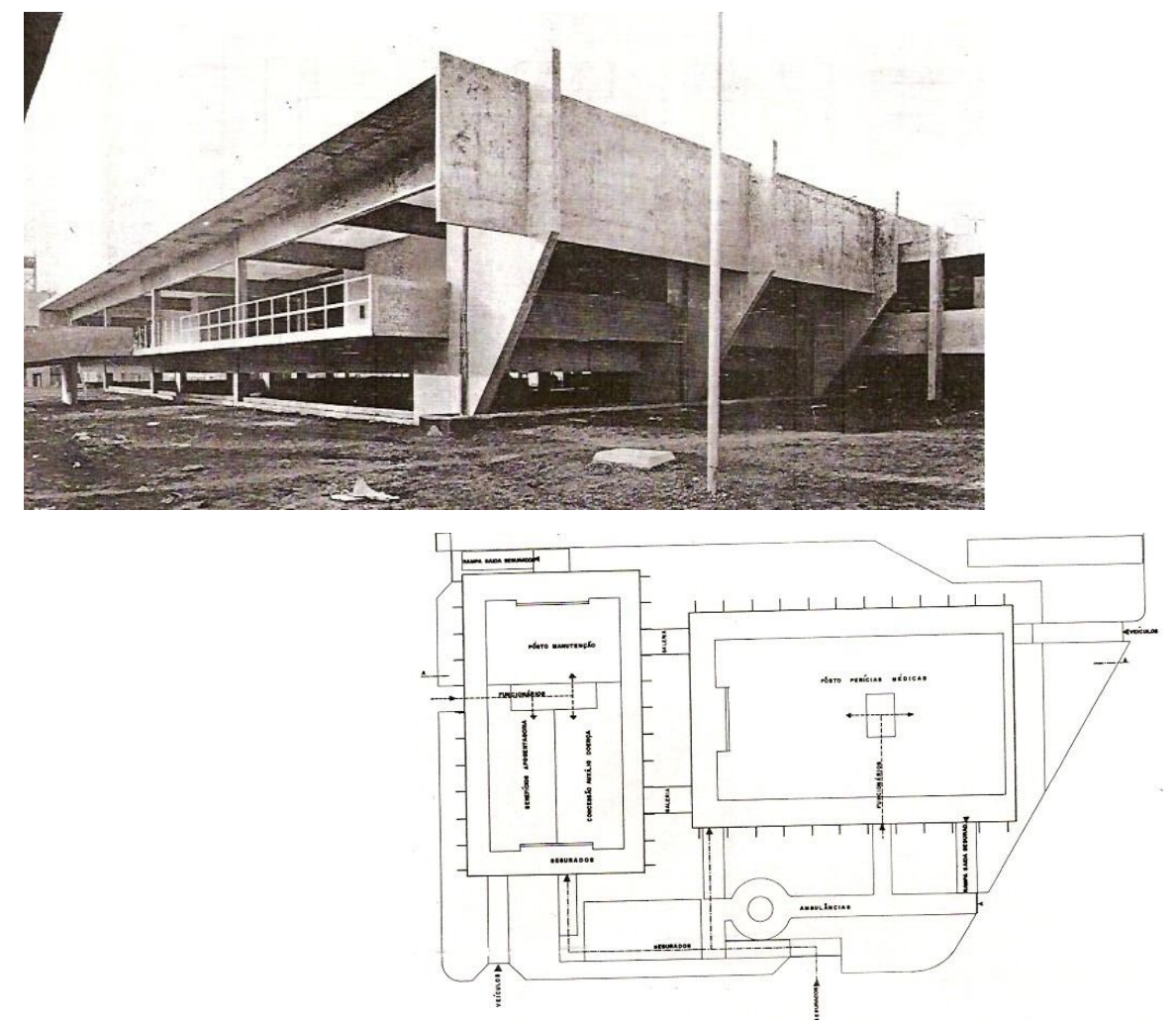

(figs. 199-200) Foto externa e implantação.

Um dos mais importantes serviços do INPS (Instituto Nacional de Previdência Social), a Perícia M édica, acabou sendo alojado em dois grandes blocos de edifício que abrigam consultórios médicos (aproximadamente uns noventa) e no outro ficaram os serviços burocráticos correspondentes. Grandes e largas áreas de circulação oferecem tanto aos usuários quanto aos funcionários um uso confortável dos espaços, em relação às atividades que praticam.

Além disso, as divisórias dos ambientes do grande salão foram pensadas de modo a serem removíveis, garantindo grande flexibilidade no layout dos edifícios. A estrutura foi concebida de maneira simples com elementos de apoio em concreto aparente.

Programa: Perícias médicas - Embasamento: Estacionamento / Depósito / Vestiários / Auditório; Pavimento principal: Atendimento ao público / Consultórios / Espera / Sanitários. Prédio de Concessões - Embasamento: Estacionamento / Depósito / Vestiários; Pavimento principal: Atendimento ao público / Cozinha / Balcão funcionários.

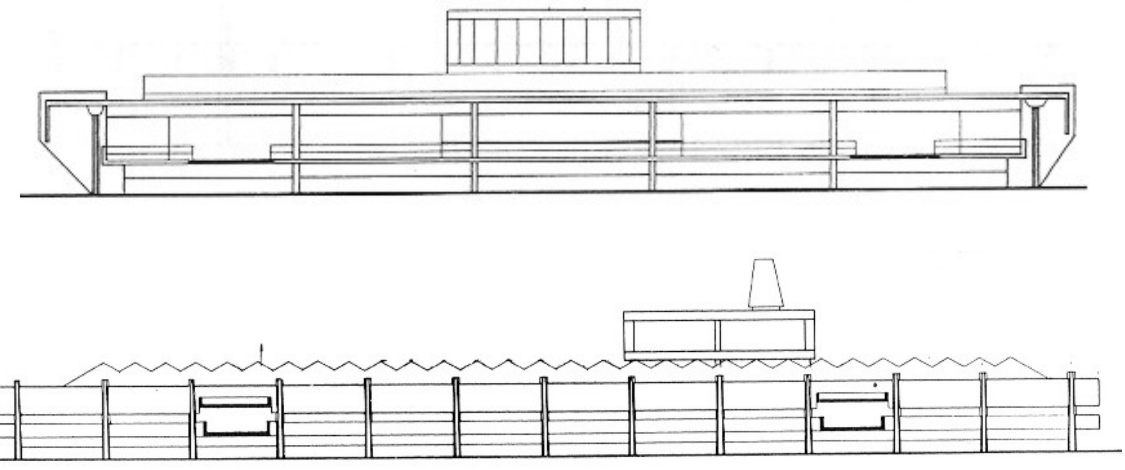

(Figs. 201-202) Elevações - Prédio Perícias (acima) e Prédio Concessões (em baixo) 

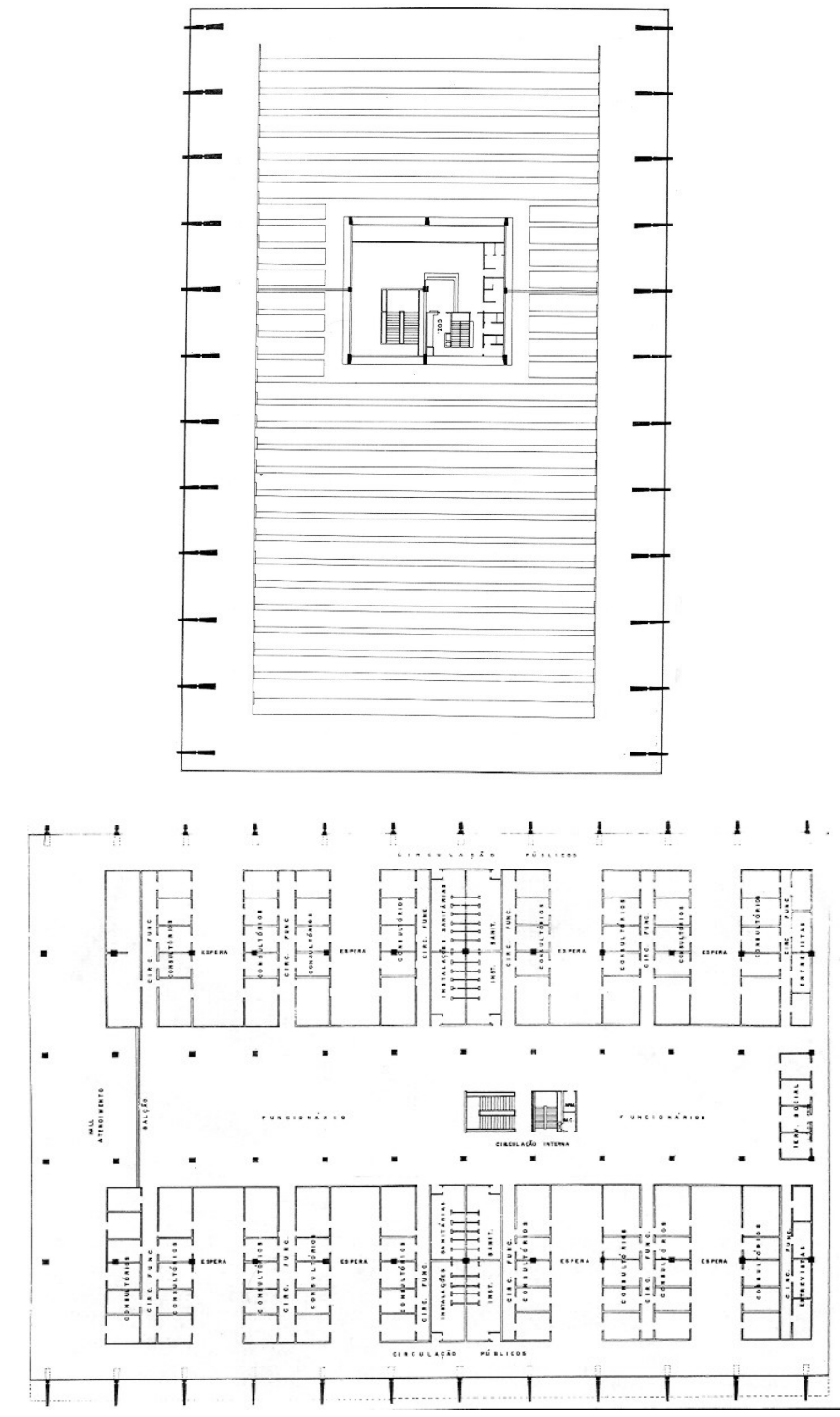

(Figs. 203-204) Plantas Pavimento Principal - Prédio Concessões e Prédio Perícias.

\section{Associação Cristã de Moços da Lapa (São Paulo/SP, 1969 - Construído)}

Projeto: Zenon Lotufo / Vitor Amaral Lotufo

(Fonte: Revista AB n. 8, pp-18-25).

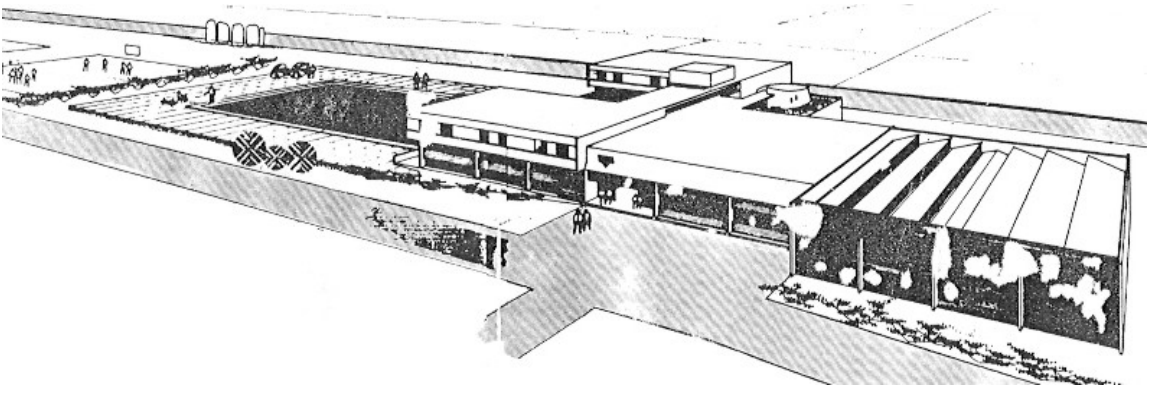

(Fig. 205) Perspectiva ilustrativa

Um terreno de aproximadamente 12 mil m2 situado no bairro da Lapa foi obtido através da prefeitura e da anuência da Companhia City de Melhoramentos, para a construção de mais uma unidade da Associação Cristã de M oços (ACM ). No entanto, ficaram estabelecidas limitações quanto à ocupação do lote, que não poderia ultrapassar 1/5 da área total, e também o gabarito de altura máxima de $8 \mathrm{~m}$.

Programa: Piscinas / Ginásio poliesportivo / Salas para ginástica / Quadras ao ar livre / Parque infantil / Sala para jogos / Auditório / Administração / Serviço médico / Apartamentos / Cantina 


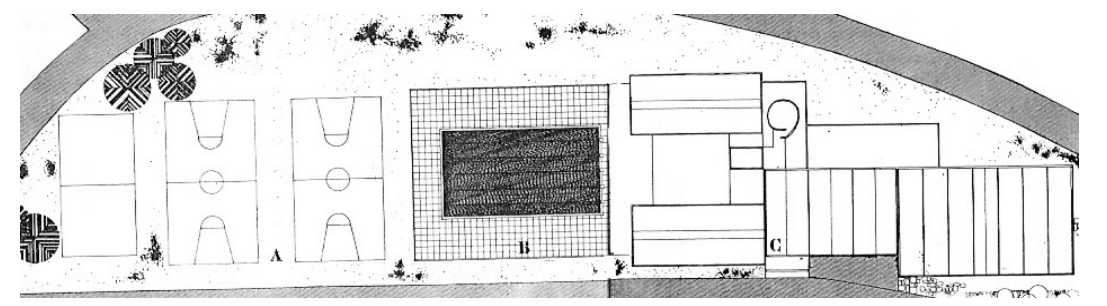

Implantação

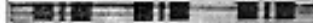

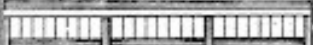

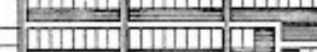

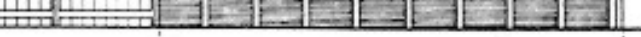

Fachada acesso principal

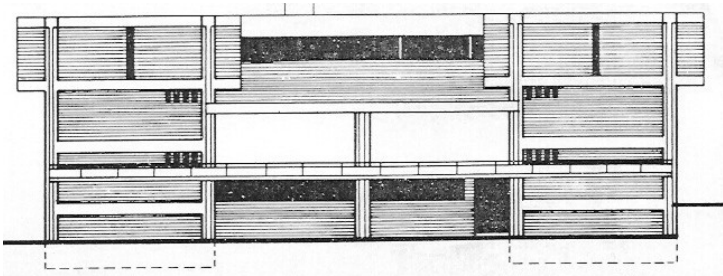

Elevação lateral - piscinas

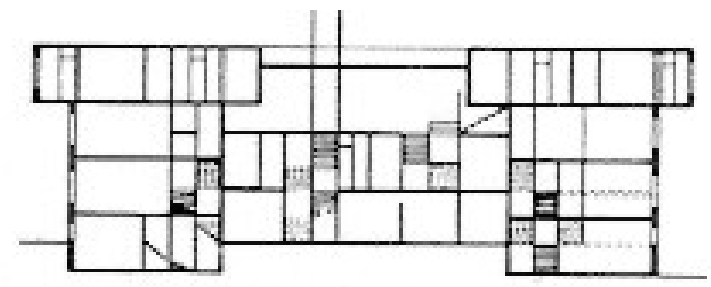

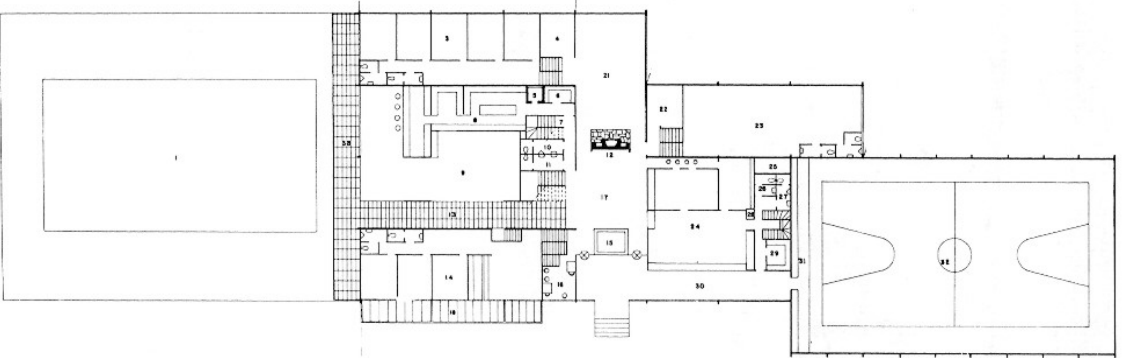

Planta Térreo

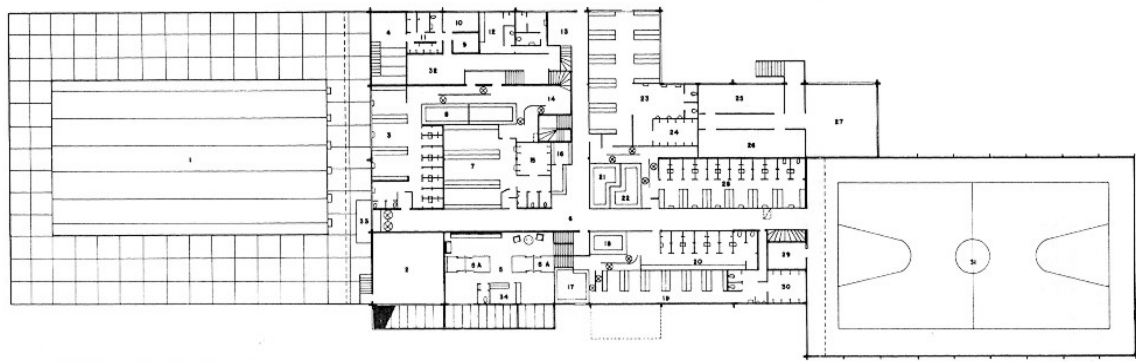

Planta $1^{\circ}$. Pavimento

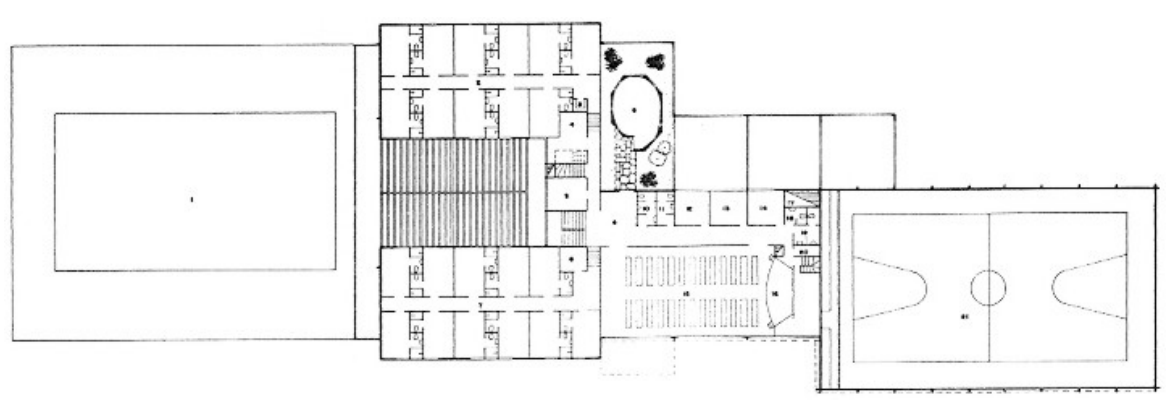

Planta $2^{\circ}$. Pavimento (Figs. 206-212) 
Escola Técnica Federal de São Paulo (São Paulo/SP, 1969 - Construído -

Concurso privado - projeto vencedor)

Projeto: Zenon Lotufo / Vitor A. Lotufo / Victor Pini / Cláudio Sganzerla.

Fonte: Acrópole 363, jul 69, pp-36-39.

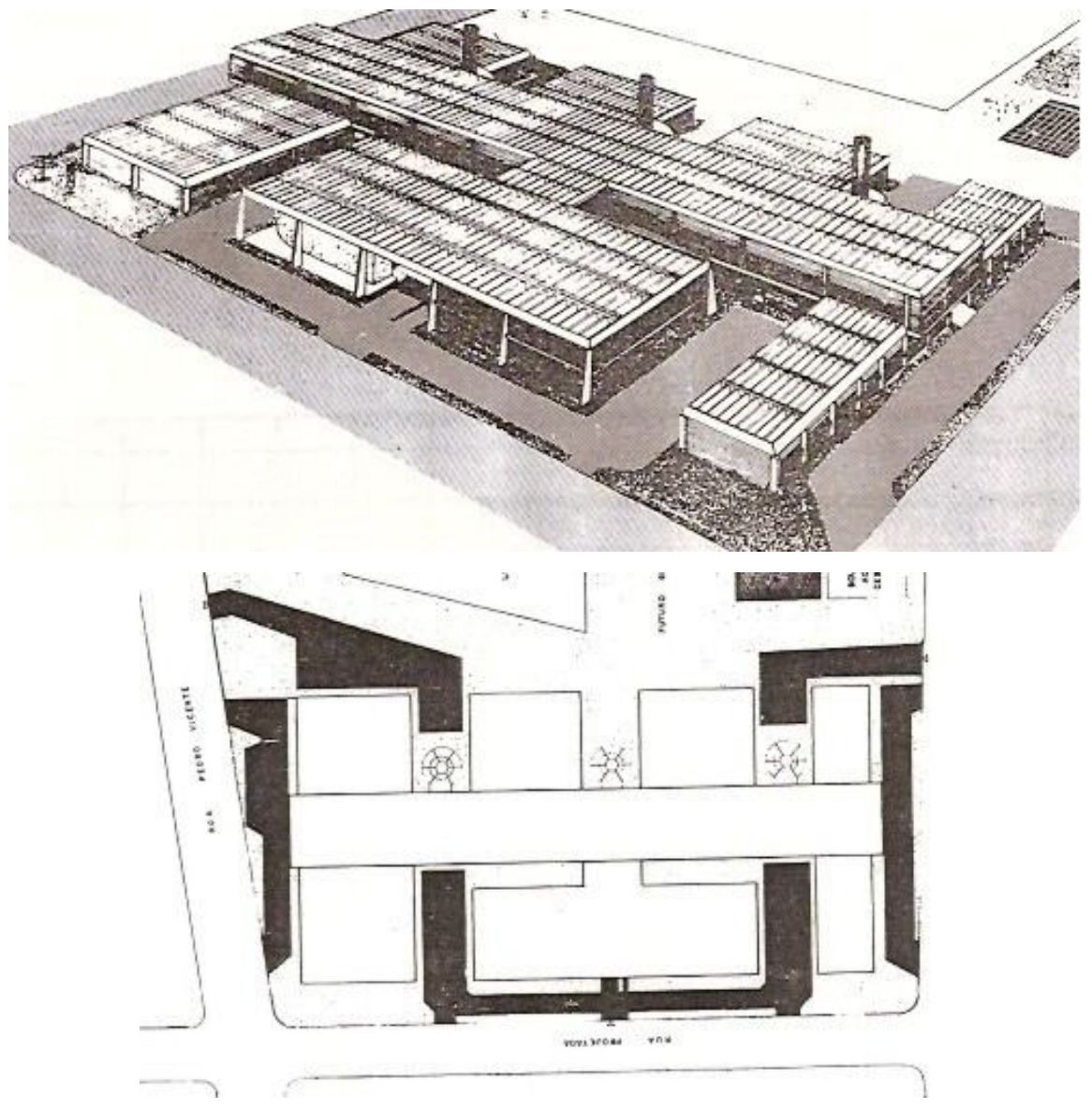

(Figs. 213-214) Perspectiva e implantação
Preocupado com a difusão do ensino técnico em todo o território nacional, o M inistério da Educação e Cultura construiu na cidade de São Paulo, uma das maiores escolas técnicas da América Latina à Av. Cruzeiro do Sul. Com área próxima de 30 mil metros quadrados, este projeto foi 0 vencedor de um concurso privado onde participaram apenas arquitetos selecionados por seus currículos e experiência na área de projetos educacionais. 0 projeto caracteriza-se pela sua organização horizontal dentro de uma clara funcionalidade das circulações. Estruturalmente foram empregados elementos pré-moldados a serem fabricados no próprio local.

Programa: Térreo: Auditório / Oficinas / Secretarias / Administração / Vestiários / Rampas; Superior: Salas de aula / Laboratórios / Anfiteatros / Cantina / Biblioteca / Sanitários.

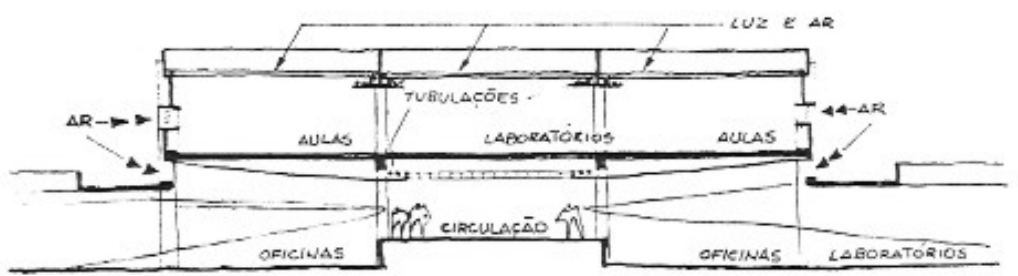

(Fig. 215). Corte esquemático - Circulação. 


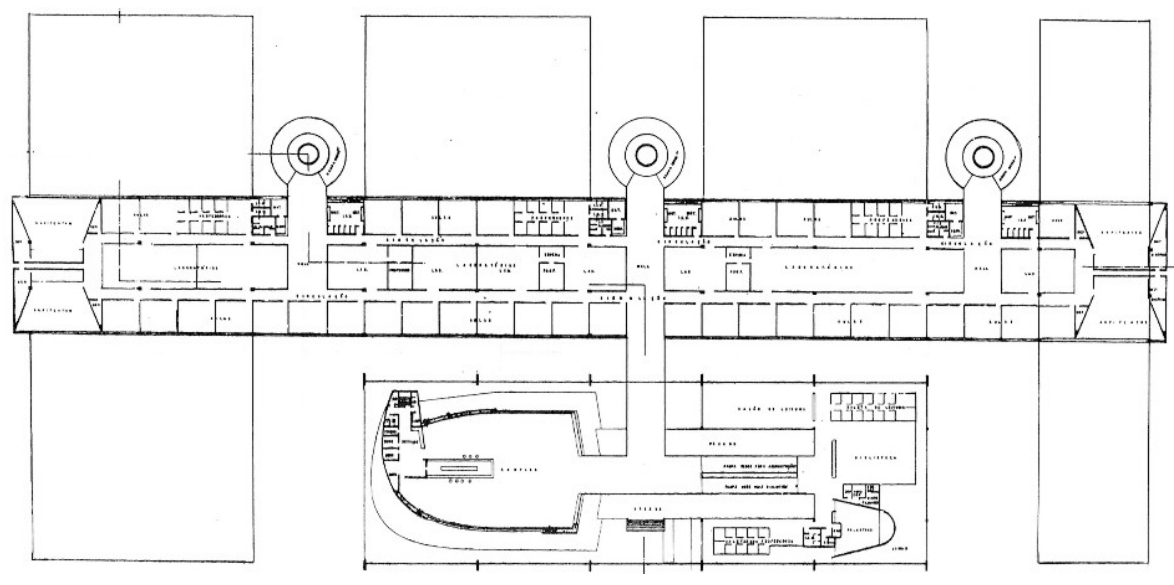

Velório do Cemitério Araçá (São Paulo/SP, 1972 - Não Construído) Projeto: Zenon Lotufo / Vitor Amaral Lotufo (Fonte: Revista AB n. 8 (1974), pp-26-31)

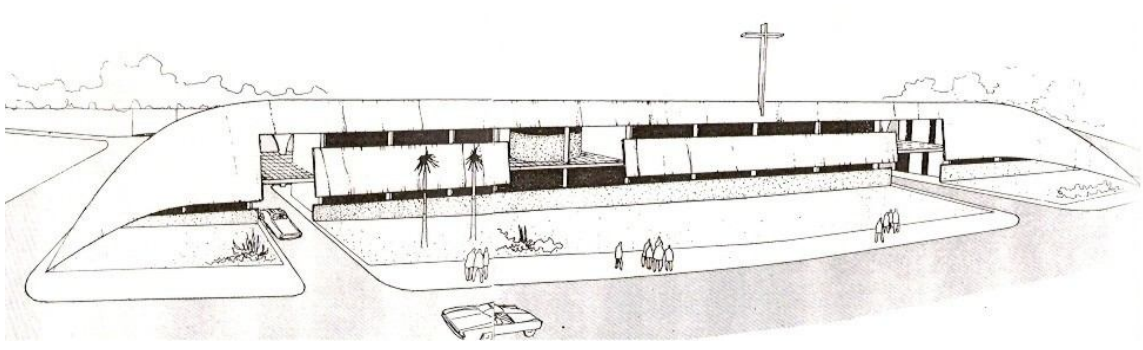

(Fig.218) Perspectiva ilustrativa.

O Serviço Funerário do M unicípio de São Paulo resolveu construir vários edifícios com o mesmo programa a fim de prestar um bom serviço a população. Este projeto seria construído na rua Itatinga limitando-se aos fundos com o cemitério do Araçá.

A topografia do terreno foi respeitada tendo a circulação orientada no lado interno através de uma larga galeria próxima ao estacionamento. A forma e a estrutura do edifício acabam sendo conseqüência desta disposição.

Programa: Inferior: Estacionamento / Galeria / Estar / Câmaras / Escritório / Banca de flores Superior: Estacionamento / Galeria / Estar / Câmaras / Bar / Cozinha.

(figs. 216-217) Plantas Superior (acima) e Térreo 

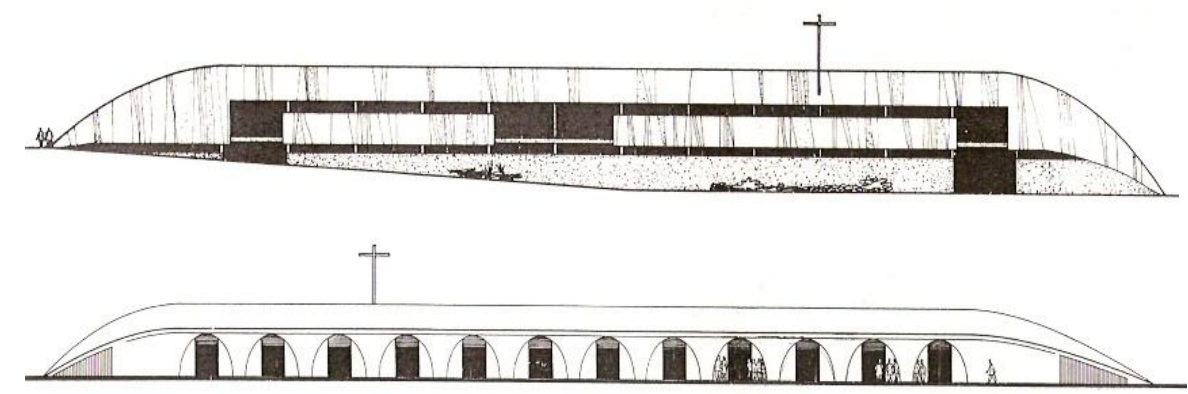

(fig. 219-220) Elevação frontal e fundos
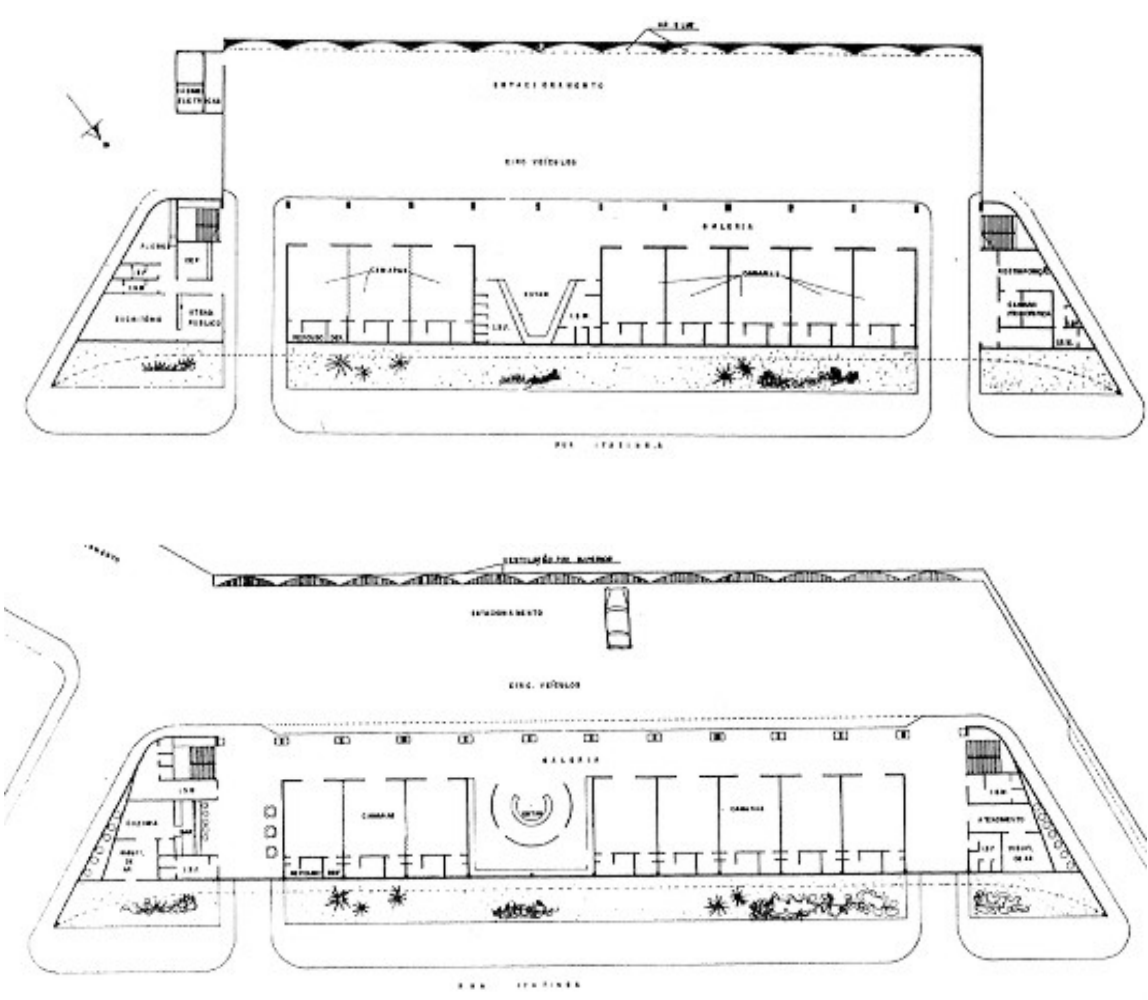

(fig. 221-222) Planta inferior (acima) e superior

\subsection{Anos 70}

Le Corbusier havia falecido em 1965 e alguns dos demais mestres modernos como Walter Gropius e Frank Lloyd Wright também. Foi um momento de revisão dos ensinamentos e lições modernas frente às mudanças culturais de grande ordem como o movimento pop e a cultura de massa.

0 golpe militar de 64 abalou de forma fulminante as estruturas democráticas brasileiras e mergulhou o país numa certa cegueira cultural graças à censura aos meios de informação (imprensa, rádio) e às manifestações artísticas e acadêmicas.

Mesmo assim, a arquitetura nacional procurou renovar o olhar de sua produção anterior, apostando nos processos de racionalização da construção civil e na pré-fabricação de elementos construtivos, ligados principalmente ao concreto armado.

“Foi um período (65-78) onde predominou o uso de materiais sem revestimento como o concreto aparente nas estruturas e também em alguns casos, o uso de materiais tradicionais como o tijolo e a madeira". ${ }^{137}$

Além disso, o Brasil passou de país rural para urbano (em 1970, 56\% da população brasileira viviam em cidades) onde uma cultura de massa e

${ }^{137}$ Bastos, M aria Alice Junqueira. Dos anos 50 aos anos 70: Como se completou 0 projeto moderno na arquitetura brasileira. Tese de Doutorado, FAUUSP, São Paulo, 2004. 
consumo crescia rapidamente e também já despontando um novo aspecto na paisagem das metrópoles: maciços investimentos em infraestrutura como transporte e comunicação, grandes obras civis como indústrias e terminais rodoviários, e o aparecimento de assentamentos irregulares e precários (as favelas).

Neste contexto, vemos se consolidar na arquitetura brasileira a institucionalização da exploração plástica do concreto e liberdade formal, perdendo, porém muito da sua força conceitual inaugural.

Era como se os arquitetos tivessem adquirido auto-suficiência perante 0 que acontecia ao redor do mundo. Claro que este isolamento era produto da ditadura militar, o que contribuiu decisivamente para um congelamento autocrítico de opiniões e posturas teóricas, externa e internamente.

Curioso foi que nunca se projetou e construiu tanto como naqueles anos, porém a quantidade não equivalia necessariamente à qualidade, o que acabou produzindo uma arquitetura destituída de crítica.

Formalmente, portanto, buscou-se uma reconciliação entre experiências cariocas e paulistas onde algumas das principais preocupações nas abordagens arquitetônicas desta fase foram: racionalidade construtiva com o uso do concreto aparente (ausência de revestimentos), grandes vãos estruturais, valorização dos espaços coletivos, inserção urbana criteriosa, continuidade espacial e flexibilidade de arranjos.

\section{Revista AB}

Em 1973, a revista AB Arquitetura Brasileira (n. 8) dedicou número especial a obra de Zenon Lotufo. No artigo introdutório, Ulisses Burlamaqui ${ }^{138}$ comentou as características humanistas na produção do arquiteto paulista, aproveitando para fazer uma análise do cenário arquitetônico da ocasião (curiosamente apresentando notáveis semelhanças com nosso momento contemporâneo).

“Uma nova consciência ambiental, sem programas monolíticos e rígidos, refletindo as complexas contradições da vida, confirmam existir importantes transformações no significado da arquitetura contemporânea. A morte dos grandes mestres privou a classe de suas lideranças. No momento incerto da civilização devemos assumir as responsabilidades humanas inerentes à arquitetura. Alerta ambiental: os recursos naturais começam a escassear. A demanda só faz aumentar em ritmo acelerado. É preciso produzir e consumir menos, minimizando a quantidade de meios empregados na construção, melhorando 0 desempenho dos edifícios hoje desenhados. Reduzir a poluição e a natalidade parece o caminho certo para evitar danos futuros". 139

\footnotetext{
${ }^{138}$ Arquiteto carioca nascido no Rio de Janeiro em 1925 , que realizou projetos de postos de gasolina nas décadas de 50 e 60, além de vencer o concurso privado fechado para a construção do Shopping Center Rio Sul em 1975.

${ }^{139}$ Revista AB Arquitetura Brasileira n. 8 (1973), pg. 9-10.
} 
Segundo o autor, Frank Lloyd Wright já havia postulado sua arquitetura orgânica imaginando uma harmonia espiritual entre homem, arquitetura e natureza, opondo-se ao racional-mecanicista dos anos 20.

Caberia, portanto àquela altura uma terceira postura capaz de conciliar as duas formulações opostas de modo a aceitar a máquina como ferramenta legítima de produção (racionalismo), porém valorizando a sinergia do homem com a natureza (organicismo). E afirmava, portanto:

“O CIAM X de 1956 trouxe à tona a crise do modernismo ortodoxo e o surgimento de uma nova geração descontente. Os Smithsons, Aldo van Eyck e companhia dirigiram ataques contundentes aos postulados dos mestres (recém falecidos), afirmando que a arquitetura moderna sem integrar-se a vida do seu tempo, afastava-se da realidade. Destaque para o fracasso do funcionalismo e da Cidade Jardim. Assim, dá-se início ao processo de revisão da arquitetura moderna. 0 que parecia já estar acontecendo na obra da Capela de Ronchamp em 1952 por Le Corbusier, onde parece nítida a demolição dos 5 pontos e uma exaltação das formas livres e volumes escultóricos. Naquele momento portanto parecia que 0 humanismo havia retornado como ponto de fuga no debate arquitetônico: aceitação do irracional, volta ao direito de expressão, redescobrimento das manifestações populares e regionalistas e fortalecimento da forma orgânica e dos valores humanos". ${ }^{140}$

${ }^{140}$ Idem, pg.10.
Segundo Burlamaqui, o arquiteto Zenon Lotufo substituía uma expressividade subjetiva por uma manifestação coletiva integrada ao entorno. E o resultado seria uma arquitetura despojada, singela, ascética e asséptica.

No entender de Lotufo, para o autor, o estudo do projeto partia sempre da planta, base sobre a qual se levantaria a estrutura e o volume, produzindo formas nobres, variadas e harmônicas. Por sua vez, a indústria e a modulação davam ao arquiteto as possibilidades de compor com elementos simples criando formas resultantes da melhor estrutura. Assim, a identificação com a obra de Le Corbusier seria notória em seus trabalhos, pois procuravam o justo equilíbrio entre razão e sentimento. Portanto, uma arquitetura produzida como função vinculada à forma tendo em vista o melhor atendimento ao homem e o integral respeito à natureza.

Para Burlamaqui, a intimidade com a disciplina da composição de Zenon confirmava sua maestria no manejo das formas arquitetônicas onde aperfeiçoava as áreas de circulação oferecendo momentos de trocas sociais de caráter informal, valorizando os pátios internos, significativos pontos de encontro, da troca de idéias e da formação de amizades duradouras. A seguir, reproduzimos também alguns trechos do texto "Tendências da Arquitetura" de Zenon Lotufo, escrito especialmente para a mesma revista. 
“Deve-se entender preliminarmente que há uma nítida distinção entre a Arquitetura, testemunha visível das tendências da situação econômico-financeiro ou política de uma determinada sociedade e a atividade criadora do arquiteto, impedido de atuar com liberdade. A imaginação criativa do arquiteto vem sendo esmagada pela obsessão ao monumental, ao "modernoso" e ao aparatoso. No entanto, verificamos que só foi possível o surgimento de uma nova mentalidade, novos conceitos, onde existia ou existiu liberdade para a criação. Gropius e a Bauhaus são provas desses fatos. 0 que tem ocorrido é que se exige do profissional apenas sua capacidade técnica, esquecendo-se as potencialidades do seu talento. Assim, a arquitetura deixa de ser um poderoso instrumento de renovação ou mesmo componente adequado à evolução da sociedade para, simplesmente comportar-se como um termômetro que registra a temperatura ambiente, mas não contribui para alterá-la. 0 crescimento material e o desenvolvimento tecnológico estão sufocando o pensamento e impedindo que as soluções técnicas se alinhem no mesmo plano que as idealizações artísticas. Assim, a arte passa a ser mero elemento decorativo na sociedade, usada para enfeitar e adornar. $E$ 0 arquiteto passa a ser o homem das "bossas", dos "macetes" ou torturador de formas". ${ }^{141}$

\footnotetext{
${ }^{141}$ Ibidem, pg.16-17.
}

Naquele momento, para Zenon, a pesquisa da forma havia chegado a um ponto estranho onde de um lado evidenciava-se a ausência de arte nas soluções arquitetônicas e de outro, percebia-se uma preocupação do artista em agredir uma sociedade que ele não mais aceitava. E concluindo, questionava-se:

"Para onde caminha a arquitetura? Acredito que teremos tendências bem definidas quando a Humanidade parar um pouco para pensar, e assim dar margem para que a Cultura ocupe seu verdadeiro lugar, pois à medida que se educa, o homem exige mais. Mais qualidade $\mathrm{e}$ não quantidade." 142

\subsection{Limeira - Planejamento e ensino (73-77)}

Neste mesmo período, Zenon participaria de importantes trabalhos urbanísticos como o Plano de Desenvolvimento Integrado de Limeira, Iracemápolis e Cordeirópolis, além de ensinar na Faculdade de Engenharia da Unicamp (aquele tempo situada ainda em Limeira), chegando até a ter escritório nesta cidade, onde desenvolvia os projetos. M esmo assim, ainda retornou ao quadro de professores da FAUUSP, desta vez como auxiliar de ensino, e lecionando também no Instituto de Tecnologia de Mauá. No caderno de Estudos para Obras Viárias (1974), Zenon Lotufo

\footnotetext{
${ }^{142}$ Ibidem, pg.16-17.
} 
relacionou uma seqüência de empreendimentos a serem executados, de modo a preparar a infra-estrutura viária do município de Limeira, interior de São Paulo, para sua expansão futura, tendo em vista a análise do processo histórico de crescimento urbano.

A estruturação viária proposta levava em conta os marcos geográficos importantes como o Ribeirão Tatu, origem da ocupação, posteriormente a construção da linha férrea junto ao vale do mesmo córrego, o que dividia a cidade em duas partes distintas: 0 centro e a área residencial de melhor nível, e do outro lado, os bairros industriais. 0 crescimento se deu de forma desordenada e espontânea, a partir da primeira ordenação em meados do século XIX pelo senador Vergueiro. Com os loteamentos ao redor do centro e em direção à Campinas, Piracicaba e Rio Claro, a cidade consolidou sua configuração tendo como novo marco divisório a rodovia Anhanguera. 0 transporte de cargas e mercadorias viria a acentuar 0 problema do tráfego doméstico.

O Plano de Desenvolvimento Integrado de 69 (também realizado pelo escritório de Zenon Lotufo) já previa uma reorientação da rede através de um grande anel viário em torno do município, através da construção de avenidas, viadutos e praças rotatórias, o que possibilitaria uma melhor interligação das funções viárias presentes então no território. ${ }^{143}$

${ }^{143}$ Caderno de Estudos de Obras Viárias da Prefeitura M unicipal de Limeira de 1974, elaboração de EM DEL (Empresa de Desenvolvimento de Limeira) e projeto de Zenon Lotufo.
Estação Rodoviária de Limeira (Limeira/SP, 1973 - Construído)

Projeto: Zenon Lotufo

Fontes: Boletim Informativo IAB/SP n. 53, 2006 e Revista AU n. 76, fev/mar 98, pg.102.
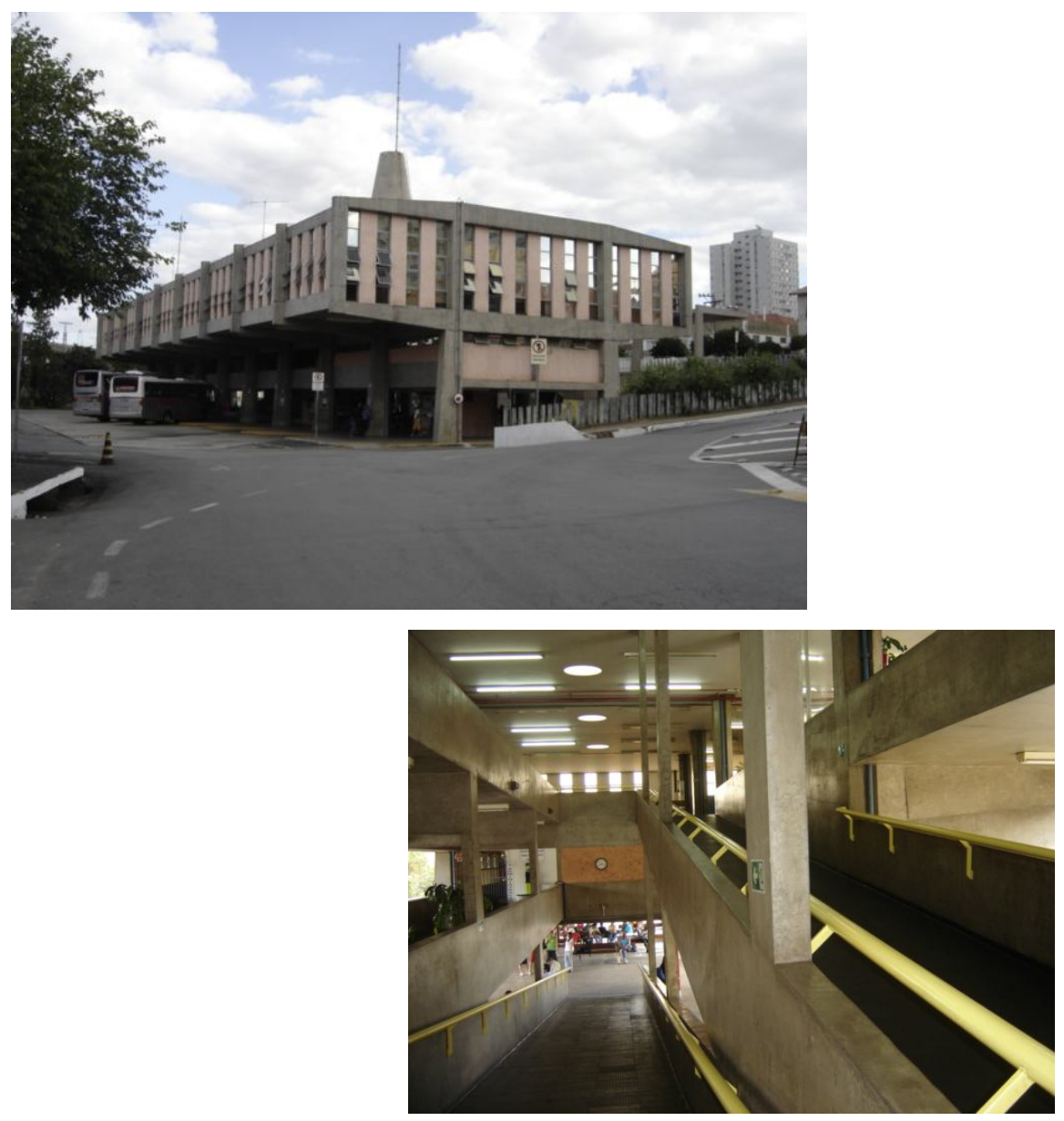

(Figs. 223-224) Fotos externa e interna - Rodoviária de Limeira. Fonte: EM F. 
Situada ao lado da antiga estação ferroviária da cidade, a Rodoviária de Limeira, interior do estado de São Paulo, um dos últimos projetos de grande porte de Zenon Lotufo, privilegia a circulação dos usuários com uso de rampas e passarelas. A planta livre do edifício e a solução estrutural em concreto armado aparente são as características fortes deste exemplar típico da arquitetura "brutalista" praticada nos anos 70 por uma boa parte dos arquitetos paulistas e demonstrava a clareza da solução que define a forma plástica do edifício. A relação entre exterior e interior garantia-se pela continuidade espacial através das grandes aberturas no térreo juntamente com as largas rampas utilizadas para circulação vertical.

Programa: Plataformas de embarque e desembarque / Bilheteria / Rampas de acesso / Sanitários / Almoxarifado / Estacionamento.

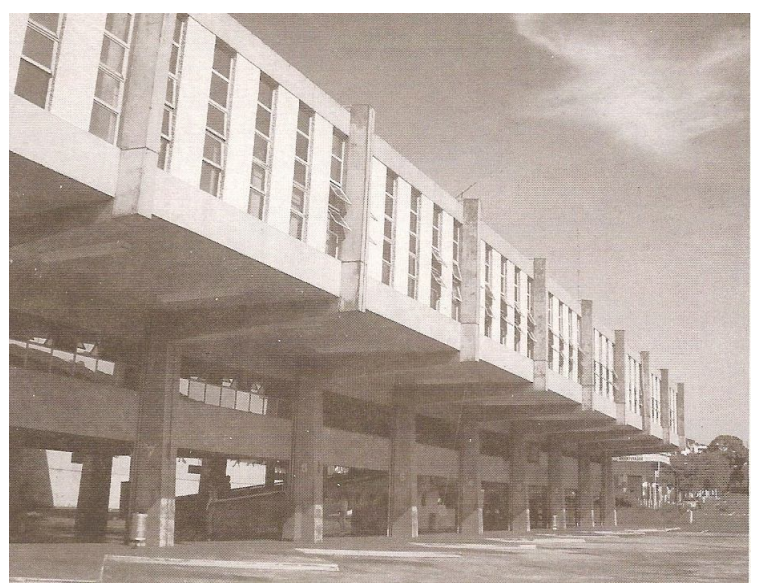

(Fig. 225) Fonte: Info IAB 53.

\subsection{Aposentadoria e os últimos anos (78-85)}

Aposentando-se pela FAUUSP como auxiliar de ensino em 1980, Zenon Lotufo retornou à sua cidade natal (Botucatu) onde comprou um pequeno sítio e ali decidiu passar, ao lado de sua família, o resto de sua humilde trajetória. Ainda assim, o arquiteto produziu trabalhos significativos.

\section{Artigos para o Jornal de Botucatu (81-82)}

Encontramos ainda alguns artigos (talvez os últimos) publicados por Zenon Lotufo, para o J ornal de Botucatu, nos anos de 1981 e 82, nas encadernações do arquivo técnico do mesmo veículo de comunicação. Dos cadernos localizados, contabilizamos 15 textos escritos neste período (81-82) para o periódico, como relatamos a seguir, com seus títulos, assunto e datas correspondentes:

- - "Óleo e gasolina" - transporte/ petróleo - (21/01/81)

- - "Planejamento" - urbanismo - (04/02/81)

- - "Planejamento - Lazer" - urbanismo - (14/02/81)

- - "Planejamento - Uso e ocupação do solo" - urbanismo $-(07 / 03 / 81)$

- - "Planejamento Urbano" - urbanismo - (25/03/81)

- - "Planejamento - Abastecimento" - urbanismo $(14 / 04 / 81)$ 
- - "Planejamento - Traçados de Cidades" - urbanismo $(06 / 05 / 81)$

- - "Experiências na vida profissional" - memórias $(23 / 05 / 81)$

- - "Arquitetura - A Casa" - arquitetura - (13/06/81)

- - "Estranha conversa" - memórias - (24/06/81)

- - "Porque perdemos" - futebol/ Copa de 82 - (14/ 07/ 82)

- - "Promessas" - política/ eleições - (24/07/82)

- - "Um Grande Clube para Botucatu" - projeto para hípica - (07/08/82)

- - "Municípios Pobres" - política - (22/ 09/82)

Notamos também que entre os títulos e assuntos abordados, destaca-se principalmente o tema referente ao planejamento e urbanismo,

aparecendo numa série seguida de seis textos. Destacamos alguns dos principais trechos destes artigos.

\section{Planejamento - Lazer}

No artigo Planejamento - Lazer, Lotufo fez nova referência às idéias de Le Corbusier citando as principais funções da cidade que eram: Habitar,

Circular, Trabalhar e Cultivar o Corpo e o Espírito.

Mas se ateve especificamente à última, criticando as posturas políticoadministrativas de certos governos que se preocupavam demais em realizar obras eleitoreiras como viadutos e prédios administrativos, em vez de oferecer mais espaços de lazer para população.

"O lazer abrange uma faixa grande de atividades humanas sendo difícil enquadrá-Io num esquema rígido de significação, por isso apreciamos a expressão - cultivar o corpo e o espírito - pois englobam as atividades fora da rotina diária, oferecendo um campo inesgotável de atividades para o homem desenvolver seu corpo (atividades esportivas e recreativas), mente e espírito (teatro, cinema, biblioteca, cultos religiosos)". ${ }^{144}$

\section{Arquitetura- A Casa}

Em Arquitetura - A Casa, Zenon Lotufo relatou uma interessante lista de condicionantes essenciais na determinação de um projeto e construção de uma residência. Para ele, inicialmente haveria al guns fatores limitantes que deveriam ser conhecidos antes de se construir uma casa: códigos de obra, terreno/ topografia e orçamento. Zenon propunha imaginar a casa sempre como lar, local privilegiado onde se viverá com filhos, parentes e amigos, devendo ser satisfatoriamente confortável.

"Assim, sua implantação deve ser correta no terreno, demonstrando clara identificação com o local. Deverá também ser

\footnotetext{
${ }^{144}$ Trecho extraído do artigo Planejamento e Lazer publicado por Zenon Lotufo no Jornal de Botucatu em 14/02/1981.
} 
funcional, sem que isso signifique prejuízo para sua forma. Le Corbusier, o maior gênio da arquitetura contemporânea, afirmava que a planta de uma construção é a geratriz de seus volumes, e bem estudada, propiciará certamente boa forma". ${ }^{145}$

Zenon reafirmava também a relação entre interior e exterior numa habitação, fato que possibilitava a integração de ambientes, influenciando-se e ampliando-se mutuamente, fazendo fortalecer o caráter de espaço público de áreas como jardins e varandas, por exemplo. Ao concluir, Lotufo expressou que um dos erros dos arquitetos modernos foi imaginar uma libertação total da forma e do conteúdo, o que despiria a casa de ornatos e decorações dando lugar às paredes lisas e a grandes superfícies envidraçadas, tal como uma vitrina de exposição. Assim, para ele, este abuso gerou ambientes frios e incômodos.

“Entretanto, os grandes talentos da arquitetura contemporânea jamais partiram para esse tipo de coisa, basta examinar as obras de Le Corbusier, Lloyd Wright, Niemeyer, Neutra e outros. 0 que eles procuraram foi adaptar a forma da arquitetura contemporânea a um novo viver, a novos materiais de construção, a novas tecnologias e a uma mão de obra que não permitia mais, o artesanato na construção". 146

\footnotetext{
${ }^{145}$ Trecho extraído do artigo Arquitetura - A Casa, no Jornal de Botucatu, em 13/06/1981

${ }^{146} \mathrm{Idem}$.
}

\section{Municípios pobres}

Num de seus últimos artigos intitulado M unicípios Pobres, 0 arquiteto deu uma visão do processo perverso que prejudicava os municípios pequenos, devido ao repasse irrisório de verbas federais.

Este fato, segundo Zenon, prejudicava a nação de modo geral, pois concentrava as atividades econômicas nos grandes centros, o que contribuía para o crescimento da violência e desemprego.

“Um país não pode ser forte com municípios fracos. 0 município é a menor fração territorial de um país. É como a célula de um corpo orgânico, se a célula enfraquece o corpo todo sofre. 0 enfraquecimento do município tem como conseqüência a falta de empregos e com isso a migração para grandes centros onde 0 trabalhador encontrará 0 subemprego. Assim, crescem as favelas, aumentam os crimes, os assaltos, a insegurança, as dificuldades de transporte, etc." ${ }^{147}$

Vindo a falecer aos 74 anos em sua cidade natal, Botucatu, em dezembro de 85 , Zenon Lotufo completou um caminho virtuoso deixando preciosas realizações e lições que permaneceram obscuras à comunidade acadêmica e arquitetônica, ou se preferirmos, à sociedade brasileira, para a qual tanto contribuiu e se dedicou profissionalmente.

\footnotetext{
${ }^{147}$ Trecho extraído do artigo Municípios Pobres, publicado por Zenon Lotufo, no Jornal de Botucatu, em 22/09/1982.
} 
"Hoje examinamos conscientemente o passado a partir do ponto de vista atual, a fim de situar o presente em uma dimensão mais ampla do

tempo, de modo que esse possa ser enriquecido pelos aspectos do passado que ainda são vitais. Essa é uma questão que diz respeito à continuidade, não à imitação". ${ }^{148}$

A idéia desta dissertação foi apresentar um panorama das principais atividades desenvolvidas no percurso profissional do arquiteto paulista Zenon Lotufo.

Neste sentido, procuramos revelar um conjunto de trabalhos realizados, reproduzindo-os cronologicamente, de modo a concatená-los ao contexto de idéias e valores pertinentes ao universo do arquiteto.

Enfocamos inicialmente sua formação acadêmica, os contatos e primeiros trabalhos, posteriormente as influências advindas pelo grupo carioca quando se afirmou sua atuação moderna, e finalmente, um último período de realizações que confirmam sua maturidade profissional.

\footnotetext{
${ }^{148}$ Giedion, Sigfried. Espaço, tempo e arquitetura: o desenvolvimento de uma nova tradição. Martins Fontes, São Paulo, 2004, p. 34.
} 
Como no título deste trabalho, por vezes arriscamos uma alusão imaginária e abstrata da intersecção entre linhas retas e curvas para traduzir um pouco da complexidade deste percurso único.

As retas serviram para ilustrar os caminhos certos, diretos e precisos do racionalismo estrutural, do funcionalismo moderno, a razão e verdade de ser das coisas, tão própria da chamada "escola paulista" de origem politécnica, que Zenon cursou.

Por sua vez, as curvas indicaram os desvios, contornos, leveza, plástica e sensualidade das escolhas e das formas, por sua vez herdada com 0 contato direto com os arquitetos da "escola carioca" de origem Beauxarts, entre eles, Niemeyer, Abelardo de Souza e Hélio Duarte.

E nesta mistura de retas e curvas, hora uma prevalece sobre a outra, hora os papéis se invertem, criando um rico emaranhado de interferências mútuas onde história, personagens e lugares se sobrepõem, destacandose assim nos trabalhos de Zenon Lotufo.

Tentamos também destacar uma noção de continuidade histórica que marca o destino e a trajetória de vida dos homens, em particular, do arquiteto paulista.

Não que estejamos presos à tradição, mas somos uma herança dela. Assim, essa idéia de rompimento com o passado é relativa e não se efetiva completamente na prática.
Somos a continuidade dos processos históricos, influenciados pelas pessoas que cruzam nossos caminhos. Conjunto de sabedorias e crenças, hábitos e culturas diferentes, nós escolhemos nossas trajetórias apoiados nessa bagagem.

Com Zenon Lotufo não foi diferente; sua formação na Escola Politécnica, a convivência com professores como Anhaia M ello, o contato com as idéias de Le Corbusier, a experiência com os cariocas da Escola de Belas Artes e principalmente Oscar Niemeyer, todo esse caldo de influências e acontecimentos permitiram a ele fazer suas escolhas teóricas e práticas.

Assim podemos também imaginar como Le Corbusier teria influenciado os arquitetos brasileiros com suas lições sobre as transformações da sociedade industrial; assim como, a sua passagem pelo Brasil (e em outros países e culturas) também teria modificado seu modo de perceber 0 mundo, o que acabou refletindo em sua arte.

A arquitetura moderna brasileira não procurou, de modo geral, romper bruscamente com a tradição e a herança colonial, o modo de construir e 0 uso de seus elementos mais característicos. Mesmo assim, buscou desfazer com cuidado os nós e se libertar com habilidade, procurando manter um vínculo permanente.

Nascida oficialmente no Rio de Janeiro na década de 30, esta arquitetura soube colher os ensinamentos do mestre franco-suíço através de nomes 
como Oscar Niemeyer, Lúcio Costa e companhia, e difundí-la com autonomia através de seus trabalhos.

Em São Paulo, apesar de ter ocorrido a primeira experiência com 0 concreto armado, a casa de Gregori Warchavchik em1928, considerada por muitos como o introdutor da arquitetura moderna no Brasil, este fato não adquiriu tamanho significado quanto o projeto do Ministério da Educação e Saúde, de 37, no Rio de Janeiro.

No entanto, a chamada "escola paulista" floresceu com nomes de peso como Rino Levi, Osvaldo Bratke e Vilanova Artigas, que adotaram linhas mais austeras e soluções estruturais simples de concreto armado.

Enquanto isso, a "escola carioca" explorou a fluidez e a liberdade de linhas mais curvas e sensuais, permitidas pelo uso e a flexibilidade do mesmo material, principalmente com os trabalhos de Oscar Niemeyer e Affonso Eduardo Reidy.

“O curso de arquitetura em São Paulo diferentemente das demais regiões, tinha suas origens não nas belas artes, mas na engenharia, o que Ihes configurava uma maior familiaridade com a arquitetura enquanto questão tecnológica. M as o fator mais palpável para a materialização de uma arquitetura formalmente identificável como "paulista" deveu-se a seu caráter de continuidade à linha carioca. "149

${ }^{149}$ Segawa, Hugo. Arquiteturas no Brasil 1900-1990. Edusp, São Paulo, 1999, p. 147.
De qualquer modo, houve intercâmbios bastante salutares (idas e vindas de Le Corbusier, experiência didática de Warchavchik no Rio, Niemeyer elaborando projetos paulistas como o edifício Copan e os pavilhões do Parque Ibirapuera) para o desenvolvimento de uma arquitetura de expressão nacional de tal modo que talvez o ponto mais interessante a ser salientado seja que ambas influenciaram-se mutuamente. E que continuam influenciando, as gerações atuais com seus postulados teóricos e práticos.

Por sua vez, a trajetória de Zenon Lotufo confunde-se com a evolução de seu pensamento e formação profissional de tal modo que é possível identificar por fim certa homogeneidade na elaboração de suas idéias e valores. Elementos comuns que acabaram por sintetizar uma linha de raciocínio atenta à simplicidade e à clareza da técnica, da função e da forma, ou seja, aos princípios vitruvianos (Firmitas, Utilitas e Venustas), aliados à economia e racionalidade de meios.

Assim, baseando-se na busca do equilíbrio justo entre razão e sentimento, Zenon Lotufo foi um daqueles raros homens dignos e corretos que trilhou um caminho cheio de "retas e curvas", mas que no final, apesar dos obstáculos, pode olhar para trás com satisfação e orgulho da contribuição deixada tanto para os arquitetos como para a sociedade.

Mas se precisássemos destacar uma única característica que resumisse a obra de Zenon Lotufo, e talvez de toda uma geração de engenheiros- 
arquitetos, esta teria origem na sua formação na Politécnica onde: "Saber construir bem era uma obrigação". ${ }^{150}$

Ou seja, 0 aspecto principal a se dominar era a construção e os conhecimentos técnicos da engenharia civil, de maneira a transportá-los para a arquitetura. Esta tradição do bem construir era herança deixada também pelos polivalentes engenheiros dos fins do século XIX, nomes como Ramos de Azevedo e Anhaia Mello que se esforçavam para conciliar as teorias clássicas (Vitruvio, Alberti, Palladio, Durand, Guadet) aos ideais práticos e funcionais da era moderna, e propagá-los aos seus alunos.

\section{Contraponto: Por uma arquitetura não-global}

Em tempos atuais de globalização e sociedade de consumo, impera a cultura de imagens e as formas exuberantes da chamada "arquitetura do espetáculo", despontando nos trabalhos de arquitetos internacionais como Frank Gehry ou Santiago Calatrava, por exemplo. Seus mega projetos para corporações multinacionais refletem o poderio do capital global e traduzem os interesses imediatos de seus clientes: uma arquitetura de se encher os olhos.

No entanto, há que se questionar a qualidade destes empreendimentos e até que ponto atende as reais necessidades humanas de abrigo e bem-

${ }^{150}$ Reis. N. G. (coorden.). Catálogo de exposição “100 anos de Ensino de Arquitetura e Urbanismo em São Paulo", LAP-FAUUSP, 1996. , pg. 9. estar. Há que se rever crítica e atentamente estas questões permanentemente, pois muitas vezes a verdade pode se esconder por trás de formas sedutoras

Questões como relação com a vida (programa), a natureza (geografia e clima) e a técnica (construção), bem como a economia e racionalidade de meios foram fatores determinantes para os autênticos modernos, e aqui encaixamos seguramente a figura de Zenon Lotufo. E ainda hoje, acreditamos que se fazem fundamentais para qualquer tipo de ambiente a ser planejado e construído corretamente.

Assim, reavaliar os principais valores e princípios divulgados por uma geração de arquitetos formados nas décadas de 30 e 40 em São Paulo, ou seja, sobre o cunho de uma modernidade latente que florescia é também, rever a permanência e força das lições deixadas por eles.

\section{Último lembrete}

A finalidade última desta pesquisa nunca foi esgotar os pormenores na vida ou obra do arquiteto Zenon Lotufo, mas sim possibilitar a abertura de novas frentes de pesquisa sobre a arquitetura paulista do século XX. É justo, portanto que se reconheça, ainda que tardiamente, os valores e lições deixados por sua personalidade humilde e íntegra, pois as próximas gerações devem refletir e julgar sobre estes acontecimentos, de modo a definir a atualidade e relevância dos mesmos. 


\section{Apêndice 1 - Residências}

Residência Francisco Lotufo Filho (São Paulo/ SP, 1946-Construída)

Projeto: Zenon Lotufo

Fonte: Acrópole n. 100, ago 46, p.121.

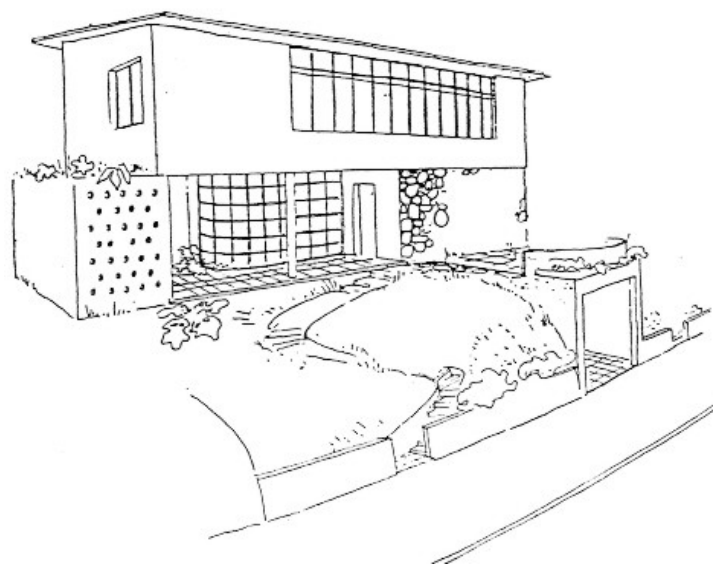

Residência unifamiliar construída para seu irmão, Francisco Lotufo Filho.

Situado em terreno em aclive, o projeto tira partido da situação topográfica minimizando a terraplanagem. Volumetria sóbria com telhado em uma água, varanda alpendrada na frente e janela em tira no pavimento superior. As áreas hidráulicas da casa (cozinha e banho) concentram-se no lado direito, sobrepondo-se uma a outra, de modo a racionalizar os encanamentos e instalações. Um jardim pergolado abre-se para a janela do escritório.

\section{Programa:}

Subsolo: Garagem para autos.

Térreo: Terraço e varanda de acesso / Hall de entrada / Sala de estar / Sala de jantar / Cozinha / Dispensa / Lavabo / Biblioteca.

Quintal: Quarto de criada / Serviços / Galinheiro.

Superior: Dormitórios / Rouparia / Banho / Terraço.

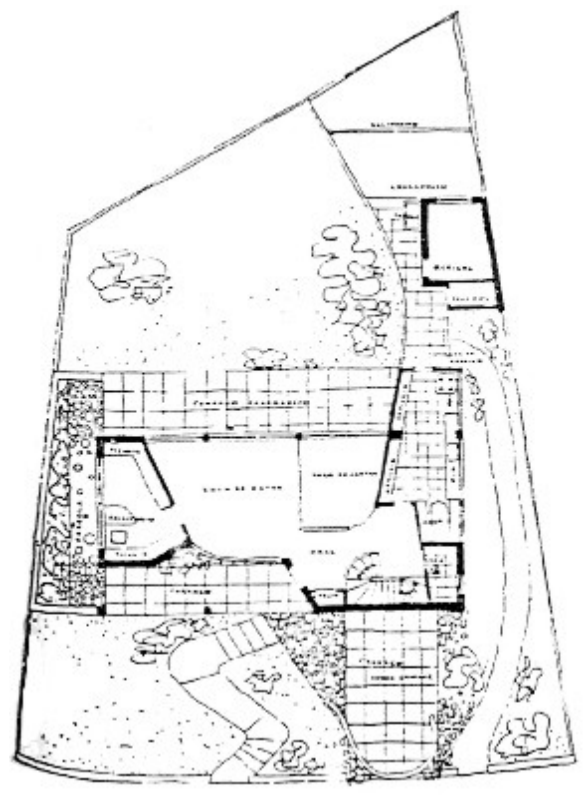

Planta Térreo

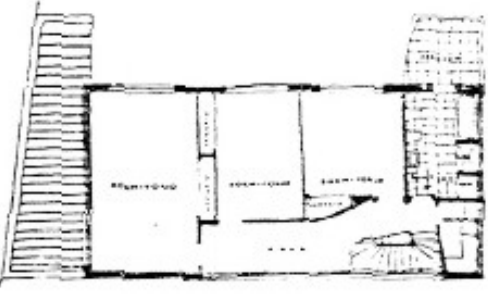

Planta Superior 


\section{Residência Vicente Huet Bacellar Júnior (São Paulo, 1946)}

Projeto: Zenon Lotufo / Abelardo de Souza/ Hélio Duarte

Fonte: Acrópole 104, dez 1946, p. 226.

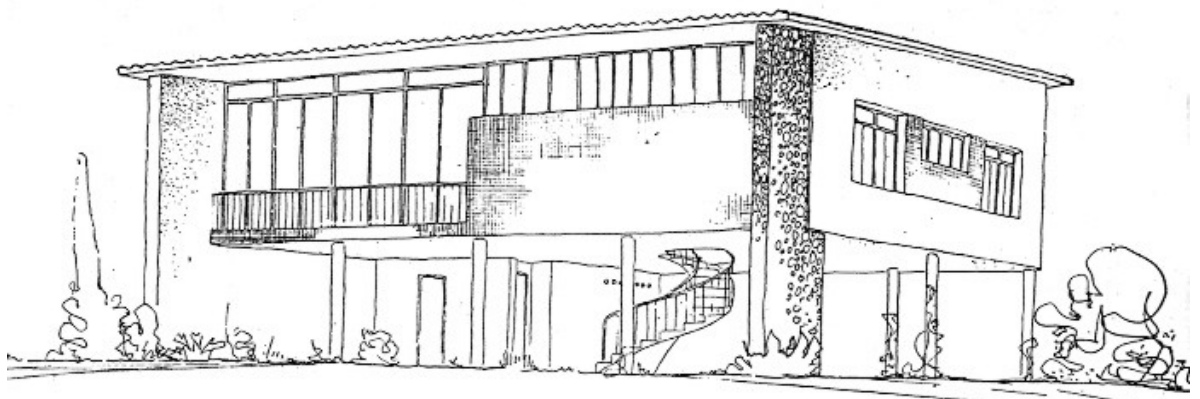

Residência unifamiliar com 320 m2, situada em terreno em aclive, 0 projeto tira partido da situação topográfica minimizando a

terraplanagem. Volumetria sóbria com telhado em uma água, varanda alpendrada na frente e janela em tira no pavimento superior. 0 bloco residencial fica solto do solo mediante o uso de pilotis criando uma ampla área de terraço coberto.

Programa: Térreo: Terraço coberto / Quarto de criada / Serviços.

Superior: Dormitórios / Banho / Sala de Viver / Lavabo / Copa / Cozinha.

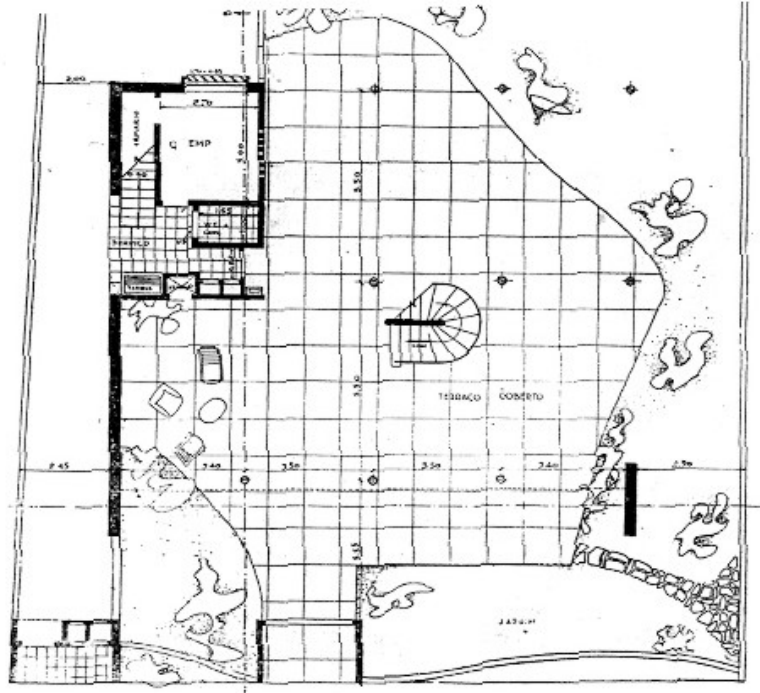

Planta - Térreo

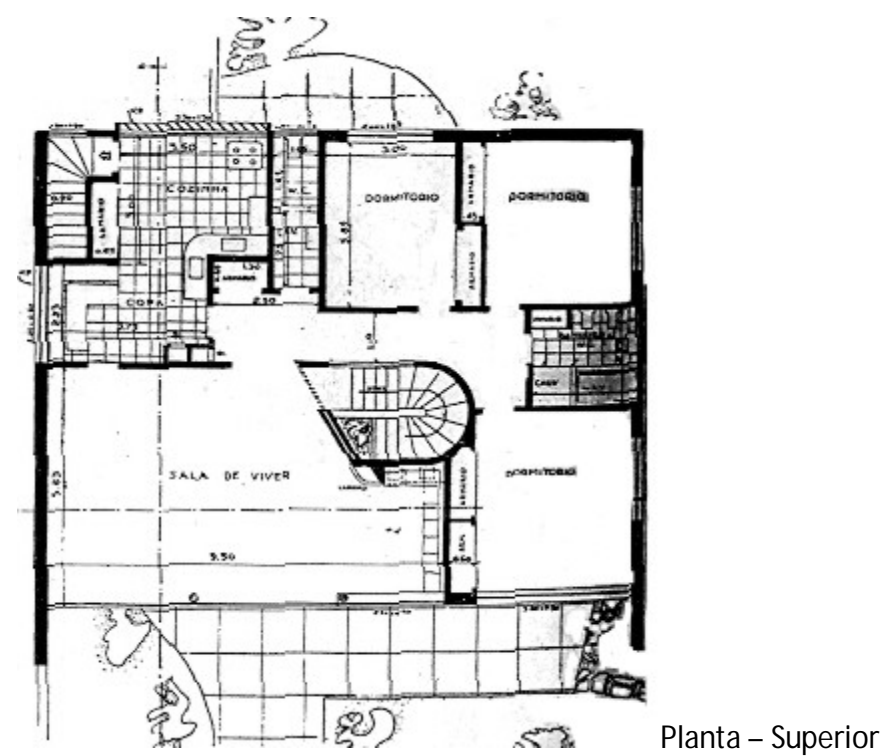




\section{Estudo de Residência (São Paulo, 1947)}

Projeto: Zenon Lotufo

Fonte: Acrópole n. 108, abril 47, pp. 315.

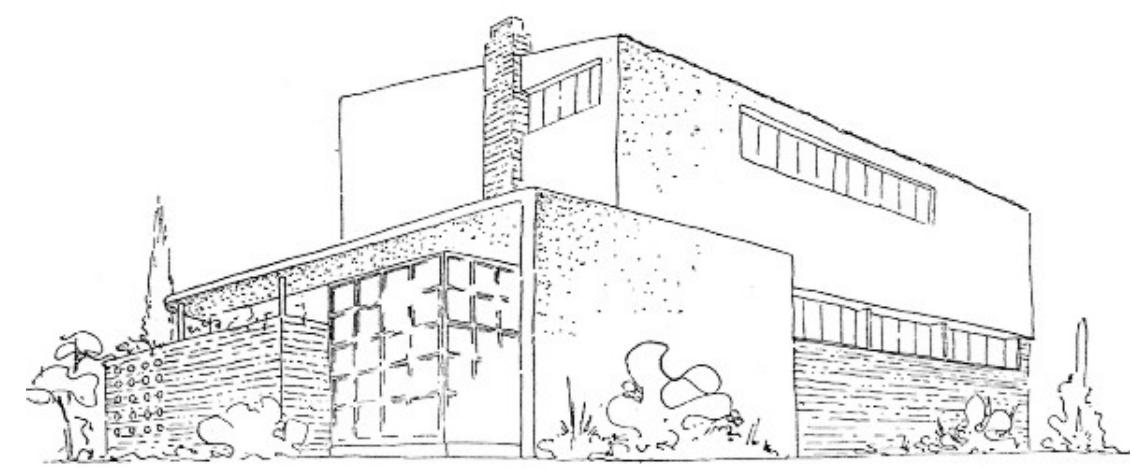

Estudo para residência unifamiliar com volumetria singular com telhado em uma água no bloco superior, varanda alpendrada na frente e janela em tira no pavimento superior. Composição volumétrica prioriza blocos puros e identificáveis como o prisma que marca a garagem e 0 acesso da rua. A janela em tira horizontal permanece como referência à matriz corbusiana. Destaque para a atenção dada aos elementos paisagísticos e a relação dos jardins com a casa.

Programa: Térreo: Terraço e varanda de acesso / Hall de entrada / Sala de estar / Sala de jantar / Cozinha / Dispensa / Lavabo / Biblioteca.

Quintal: Quarto de criada / Serviços / Galinheiro.

Superior: Dormitórios / Rouparia / Banho / Terraço.

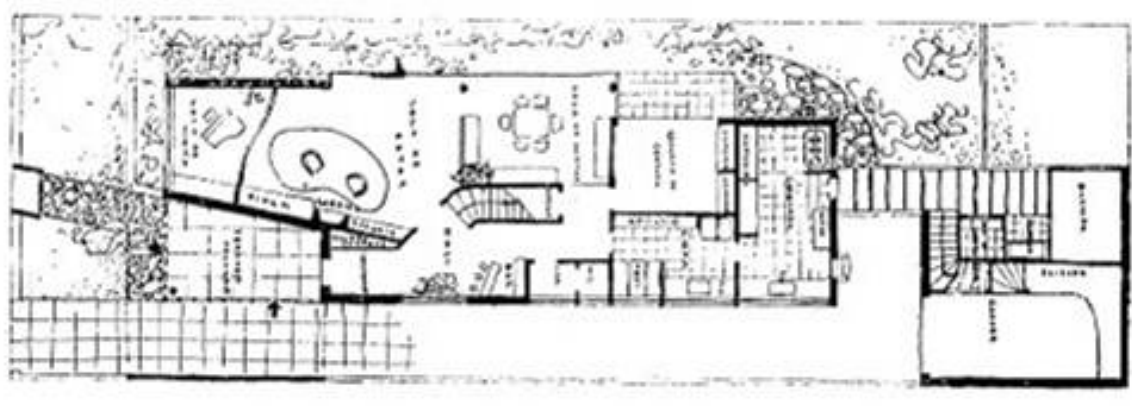

Planta Térreo
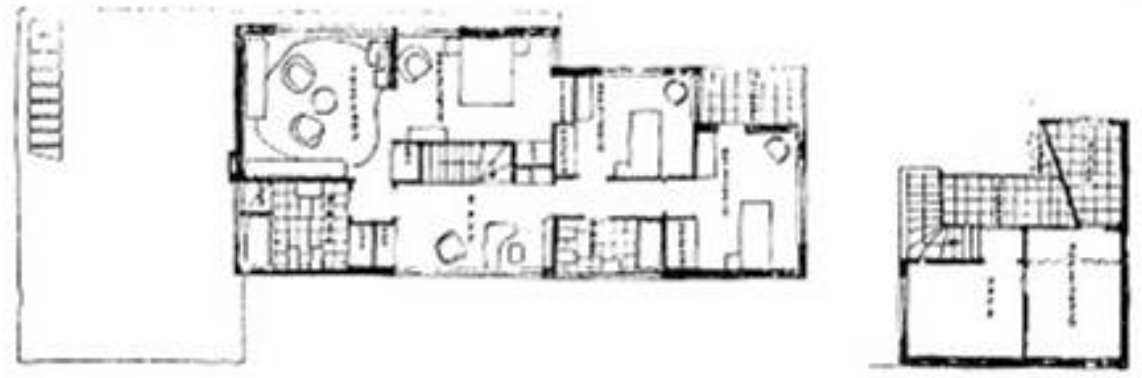

Planta Superior 
Residência Antônio Lotufo (São Paulo/ SP, 1948)

Projeto: Zenon Lotufo

Fonte: Revista Acrópole, jul 48, pp. 106-107

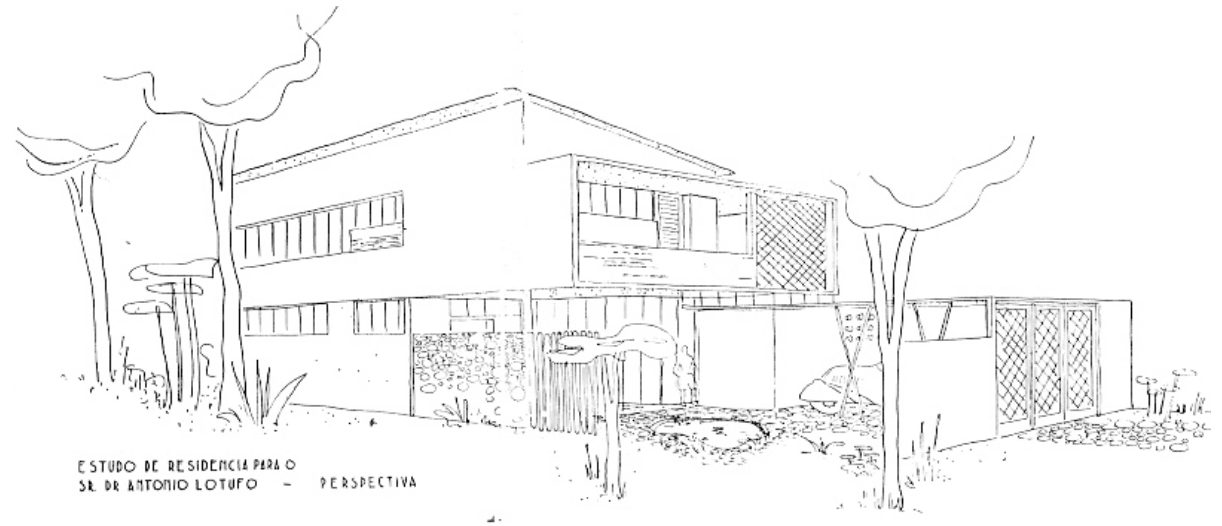

Residência unifamiliar para seu irmão, Antônio Lotufo de volumetria sóbria com telhado em uma água, varanda alpendrada na frente e janela em tira no pavimento superior. A composição privilegia os espaços de jardim e varandas otimizando os elementos paisagísticos e a relação com as áreas sociais no térreo da casa. Destaque para o aproveitamento do recuo lateral e o uso de pérgula criando um corredor-jardim que contribui para a iluminação e ventilação.

Programa: Térreo: Garagem para autos / Terraço coberto de acesso / Sala de estar / Sala de jantar / Cozinha / Dispensa / Lavabo / Biblioteca /

Quarto de criada / Serviços.

Superior: 3 Dormitórios / Banho / Terraço.

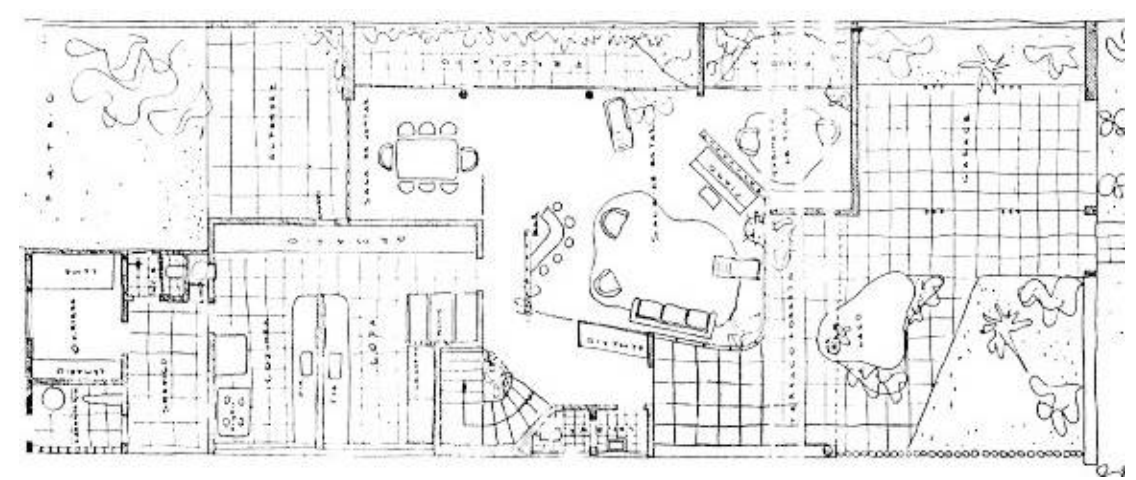

Planta Térreo

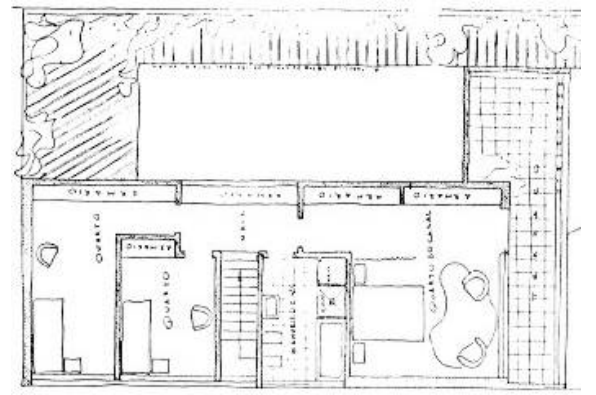

Planta Superior 
Estudo de Residência e Consultório (São Paulo/SP, 1950)

Projeto: Zenon Lotufo

Fonte: Acrópole 97, mar 50, pp. 32.

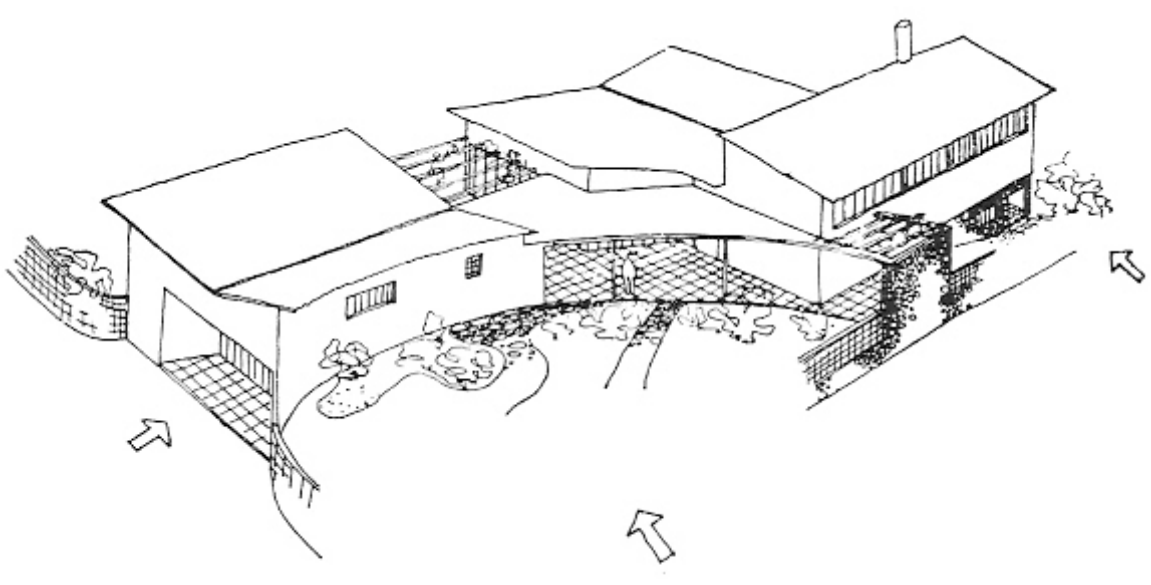

Estudo para residência unifamiliar e consultório médico com volumetria variada com telhados tipo borboleta em sentidos diferentes e bloco superior com janela em tira na horizontal. Uma grande varanda alpendrada na frente para acesso faz a distinção das funções e usos (bloco da esquerda - consultório).

Programa: Consultório (planta - lado esquerdo): Sala de Exames / Banho / Sala de Curativos / Fisioterapia / Sala de espera / Terraço.

Residência: Garagem para auto (semi-enterrado) / Hall de entrada / Sala de estar / Sala de jantar / Copa / Cozinha / Pátio / Dormitórios / Banho.

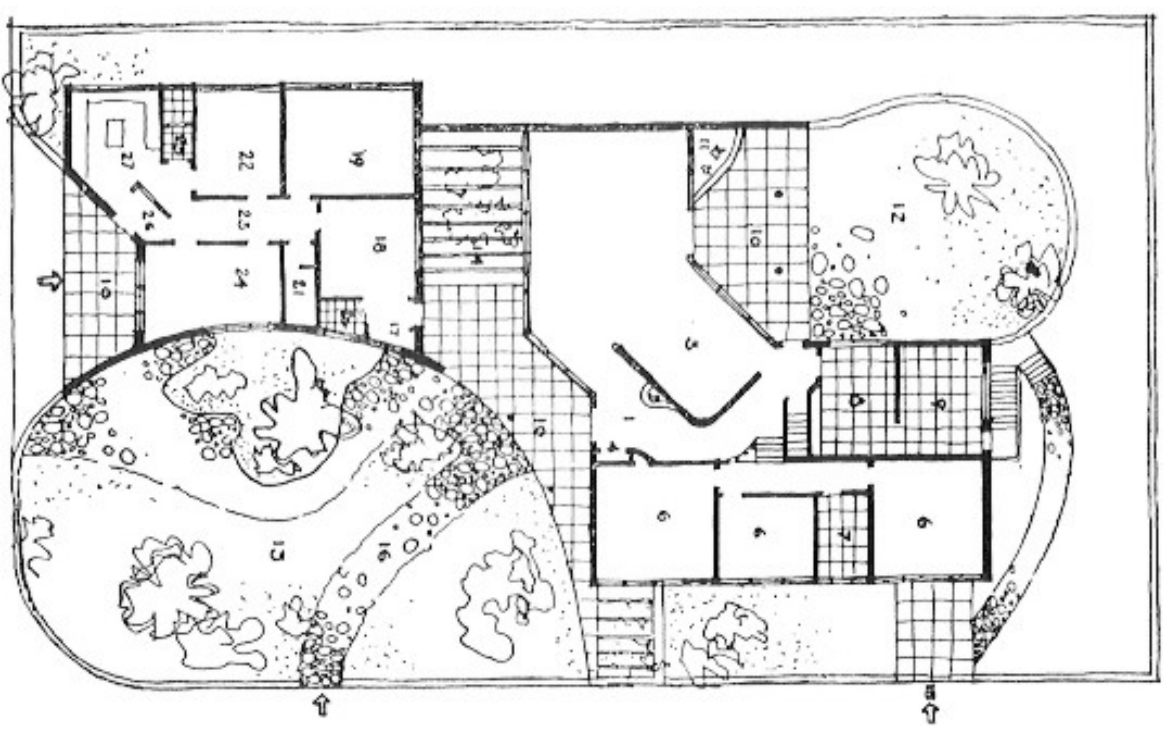

Planta Baixa 


\section{Residência Honório Sylos (São Paulo/SP, 1951- Construída)}

Projeto: Zenon Lotufo

Fonte: Acrópole, mar 51, pp. 284-28

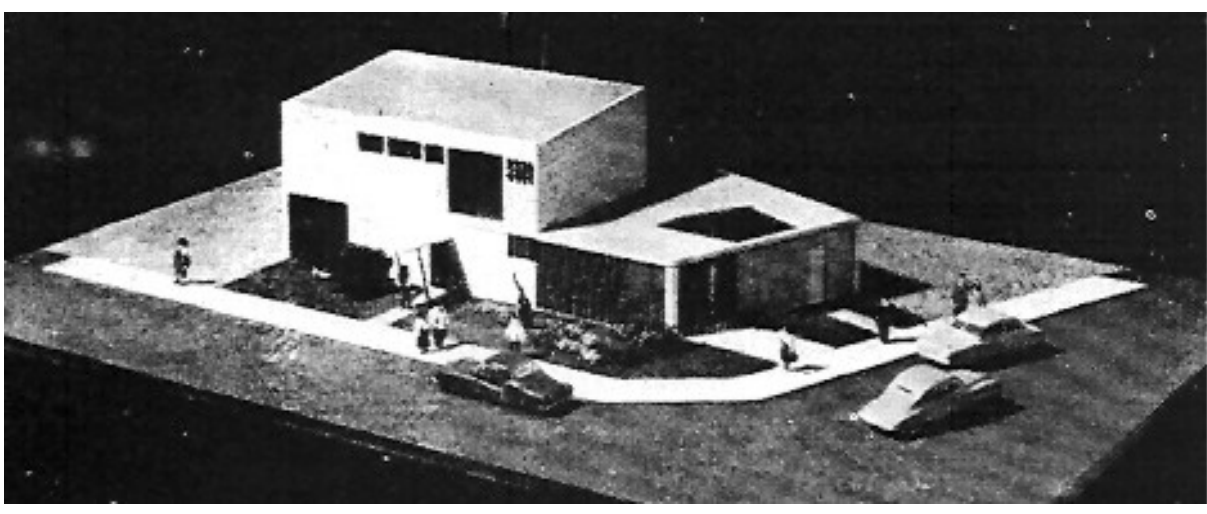

Residência unifamiliar para Dr. Honório de Sylos situada na Rua Fernandes Borges com Oliveira Pimentel, Vila Paulista, onde a ocupação do terreno gerou um pátio no fundo, além do recuo frontal de cinco metros determinado pela legislação vigente na época.

Programa: Térreo: Garagem para auto / Lavabo / Cozinha / Sala de Estar / Sala de Jantar / Escritório / Área de serviços / Quarto empregada; Superior: Suíte / Dormitórios / Banho.

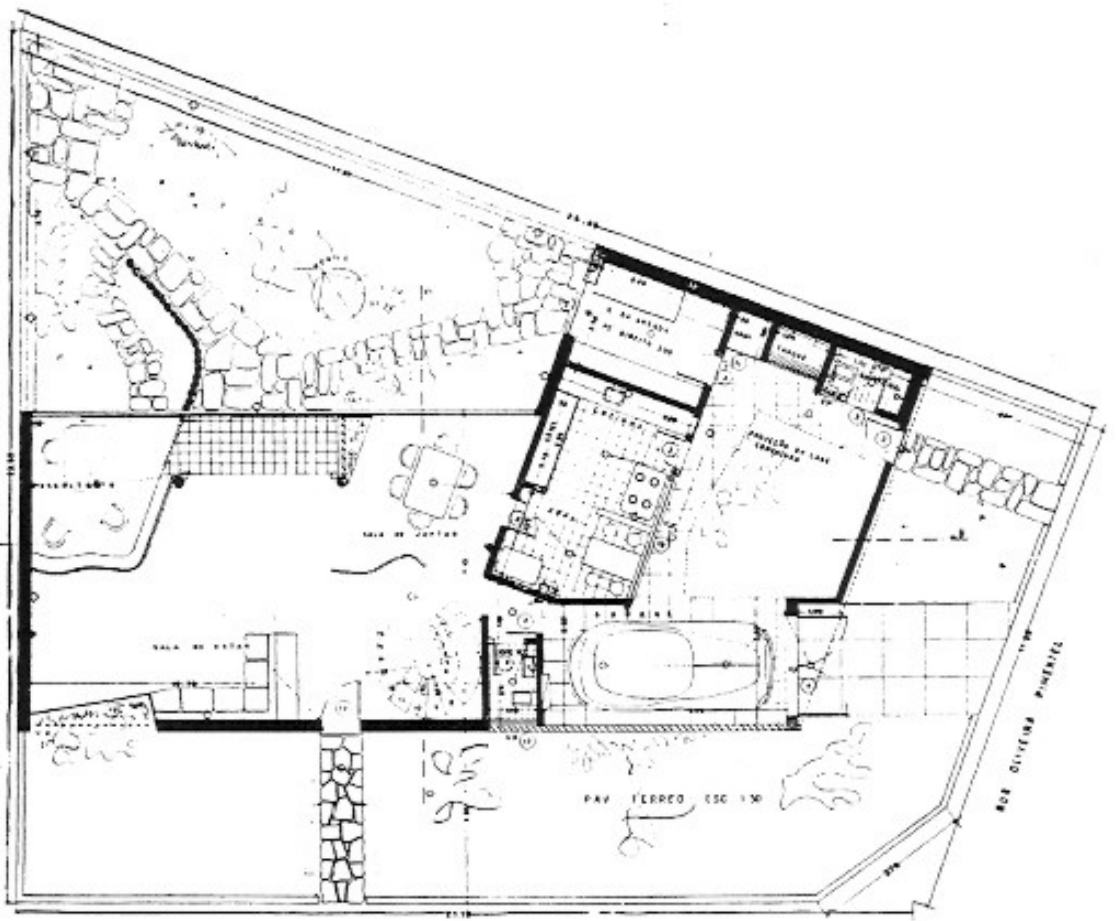

Planta Térreo

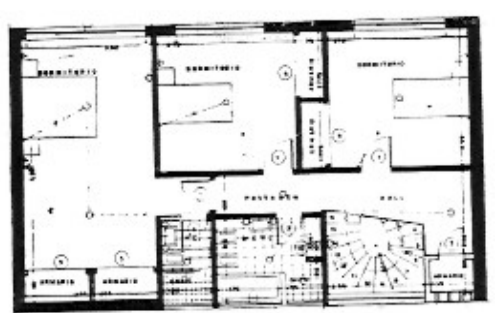


Estudo para Residência (São Paulo/SP, 1951)

Projeto: Zenon Lotufo

Fonte: Revista Acrópole 1951

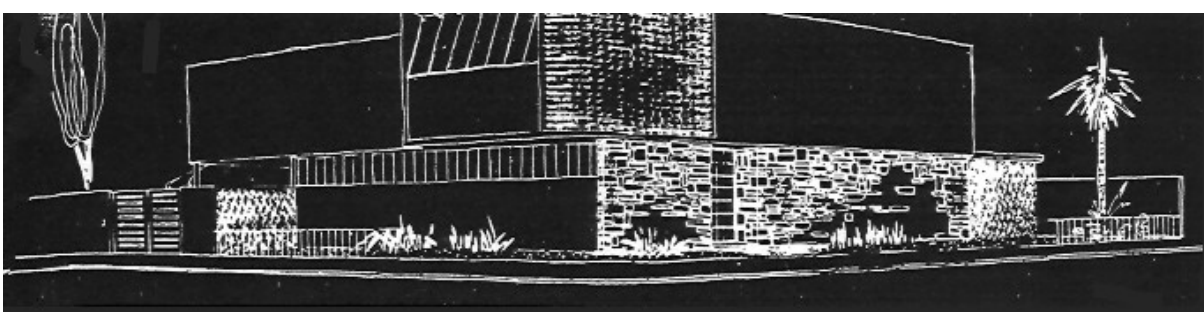

Estudo para residência unifamiliar em terreno na Rua Diogo Jácomo, de $660 \mathrm{~m} 2$, onde o programa principal ocupa o térreo em forma de "U" conformando um grande pátio social.

A parte superior foi destinada para sala de jogos, escritório, estúdio, lavanderia e aposentos para empregada, o que foge de uma disposição mais convencional com os dormitórios situados na parte de cima.

Programa: Térreo: Garagem para autos / Sala de Estar / Sala de Jantar / Copa / Cozinha / Serviços / Dormitórios / Banho / Sala de espera Superior: Terraço / Sala de jogos / Escritório / Dormitório empregada / Lavanderia / Estúdio

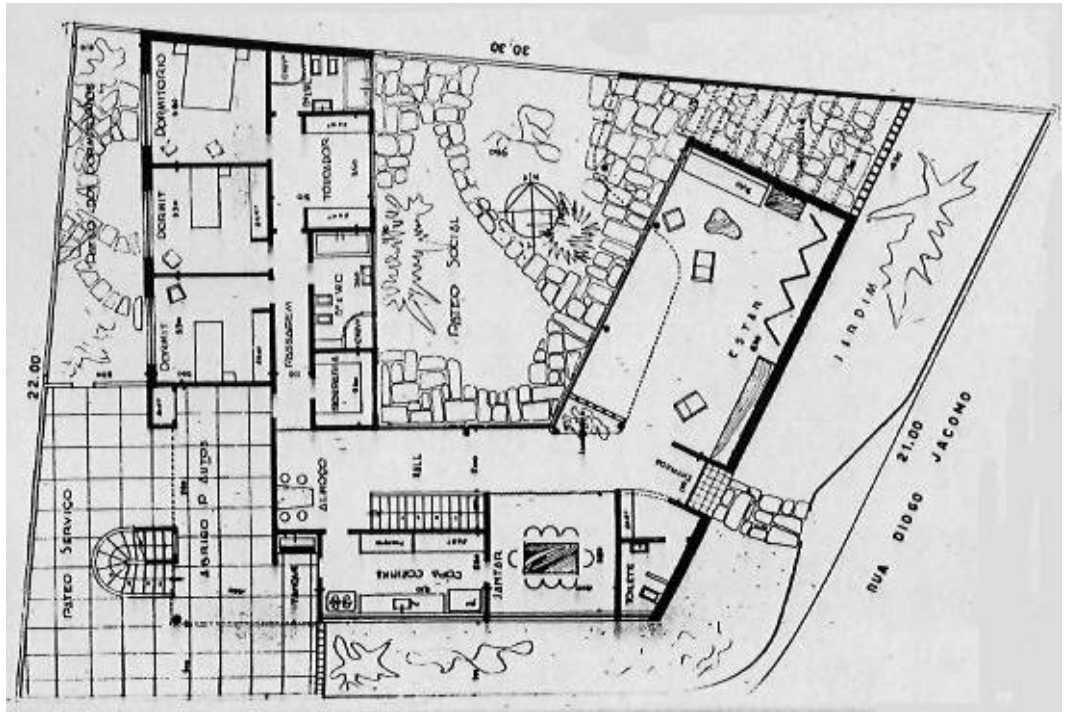

Planta Térreo

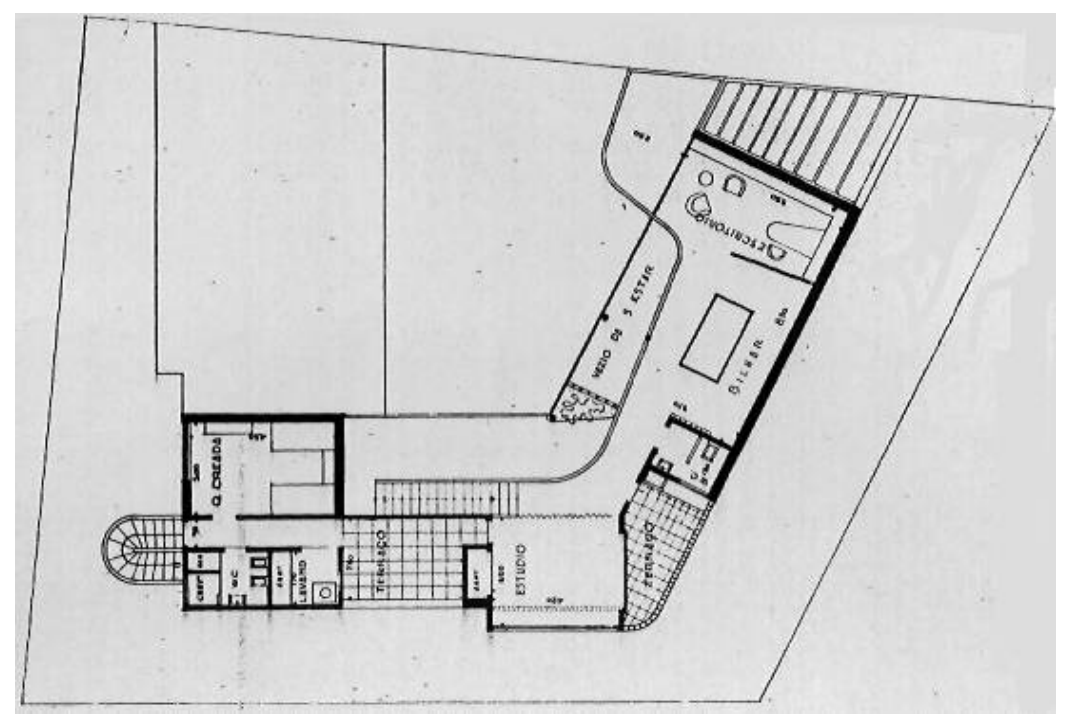

Planta Piso Superior 


\section{Residência Menezes (São Paulo/ SP, 1951)}

Projeto: Zenon Lotufo

Fonte: Casa e Jardim, pp. 4-8.

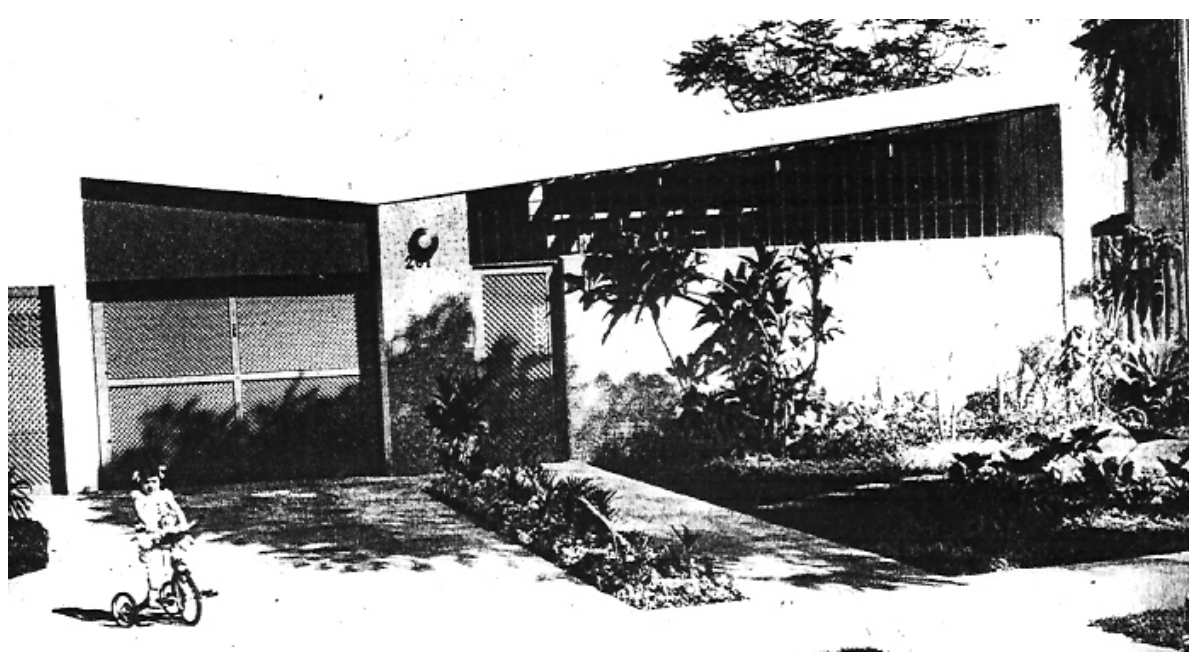

Residência unifamiliar térrea para M. T. M enezes situada à Rua Zapará no bairro de Pinheiros de volumetria elegante e discreta com telhado tipo borboleta na fachada. Esta solução foi bastante utilizada por arquitetos brasileiros nas décadas de 50 e 60, uma referência ao projeto de Lê Corbusier para a casa Errazuris em 1930 no Chile. A área hidráulica da casa (Cozinha e banho) concentra-se no lado esquerdo de modo a racionalizar estas instalações.

Programa: Térreo: Garagem para auto / Hall de entrada / Sala de estar / Sala de jantar / Copa / Cozinha / Dispensa / Dormitórios / Banho

Edícula: Lavanderia / Dormitório / Banho / Depósito

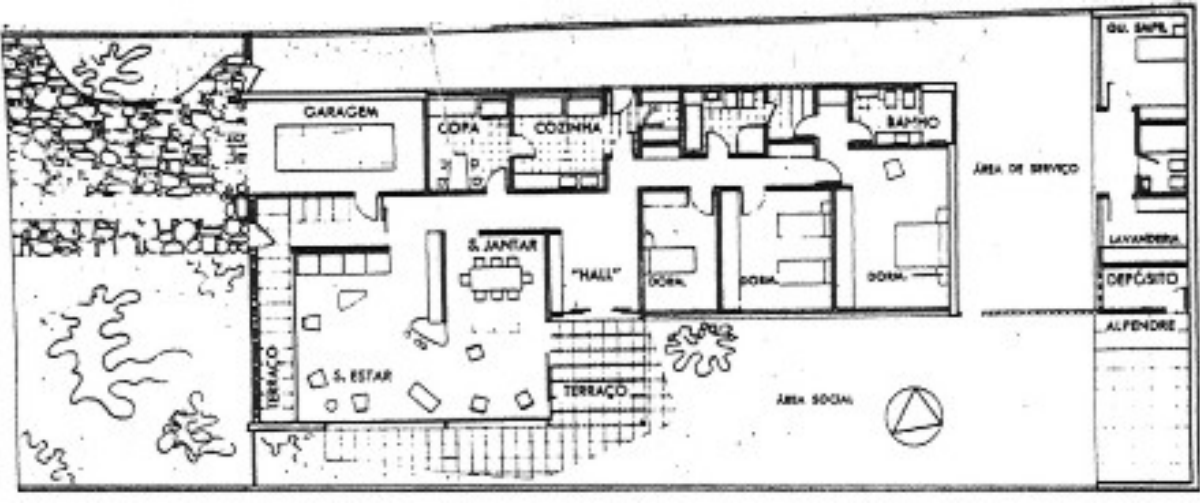

Planta baixa 
Residência Nilo Andrade Amaral (São Paulo/SP, 1954 - Construído)

Projeto: Zenon Lotufo

Fonte: Arquitetura e Decoração n.14, dez 55.

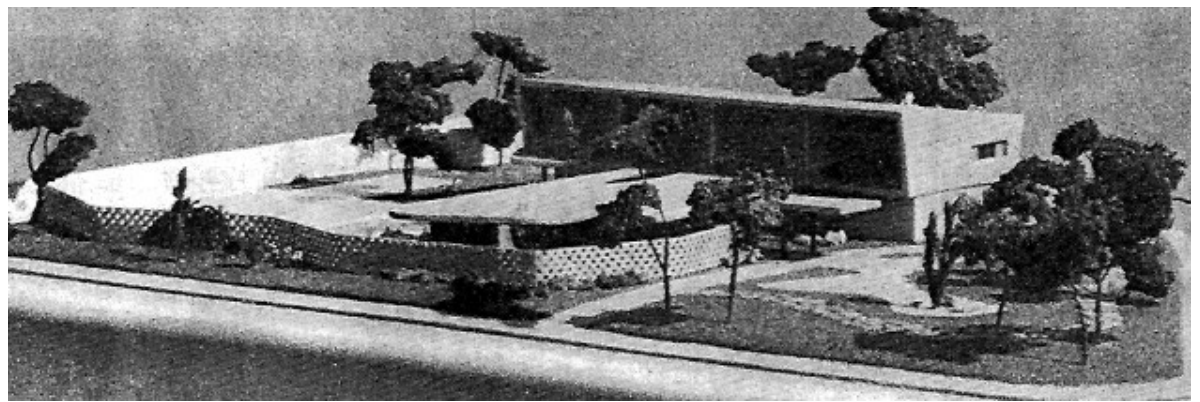

Residência unifamiliar construída no bairro do Morumbi, zona sul de São Paulo, nas proximidades da atual Fundação Oscar Americano. Consta de um bloco longitudinal onde se localizam os dormitórios, definido por uma cobertura plana inclinada, que contrasta perpendicularmente com uma grande laje plana de concreto, de traçado irregular, que desenha as dependências sociais e os jardins do andar térreo.

Programa: Térreo: Garagem autos / Escritório / Galeria de entrada / Salão social / Varanda / Piscina / Sala de jantar / Sala de estar / Cozinha /

Dispensa / Bloco de serviços com Pátio

Superior : Dormitórios e banhos.

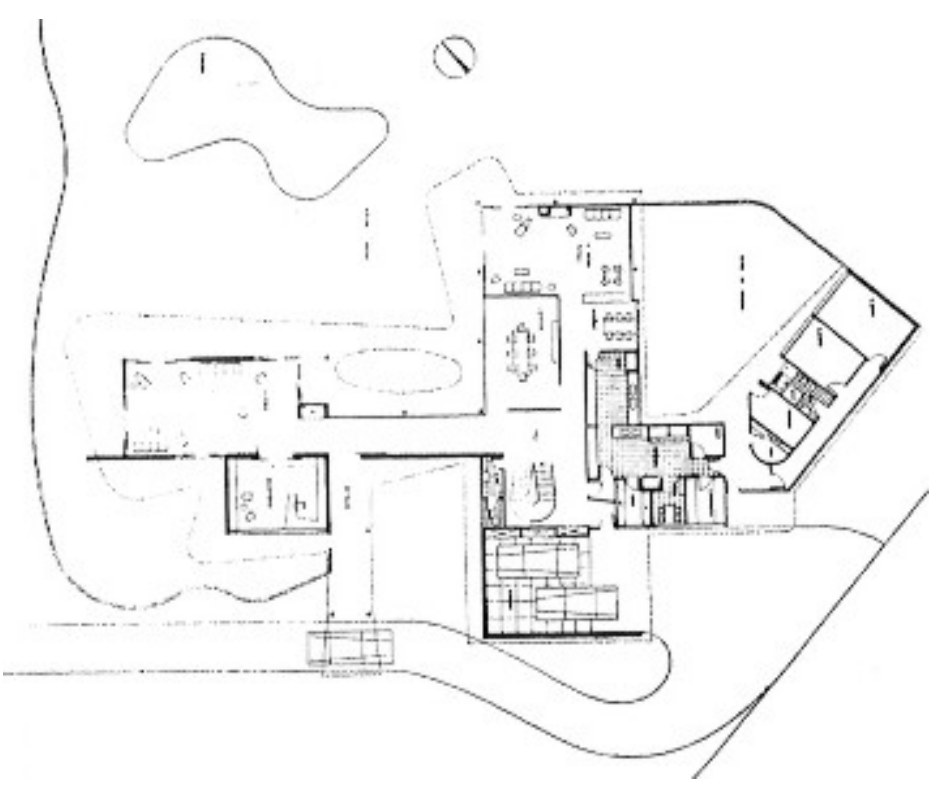

Planta Térreo

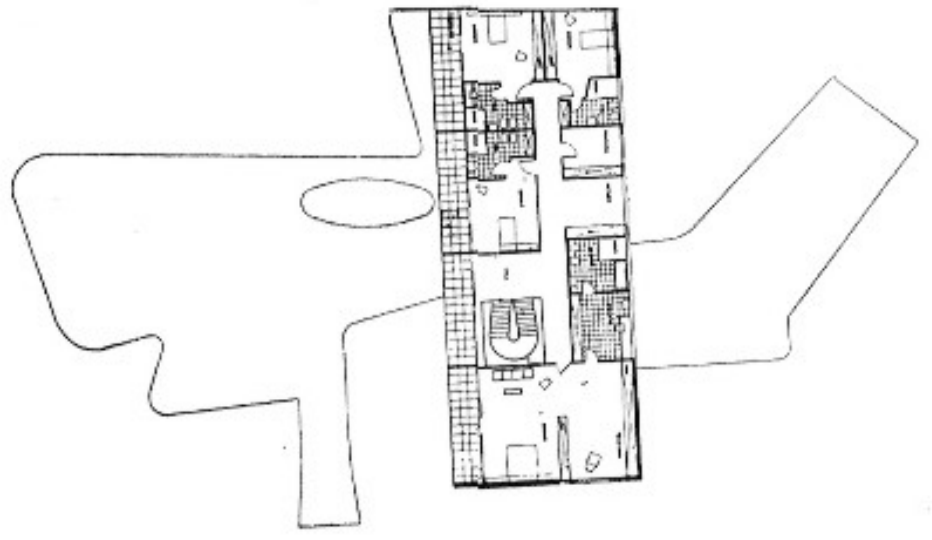

Planta Superior 
Fazenda Boa Esperança (Botucatu/ SP, 1956 - Não Construído)

Projeto: Zenon Lotufo

Fonte: Acrópole 209, mar 56, pp- 180-183.

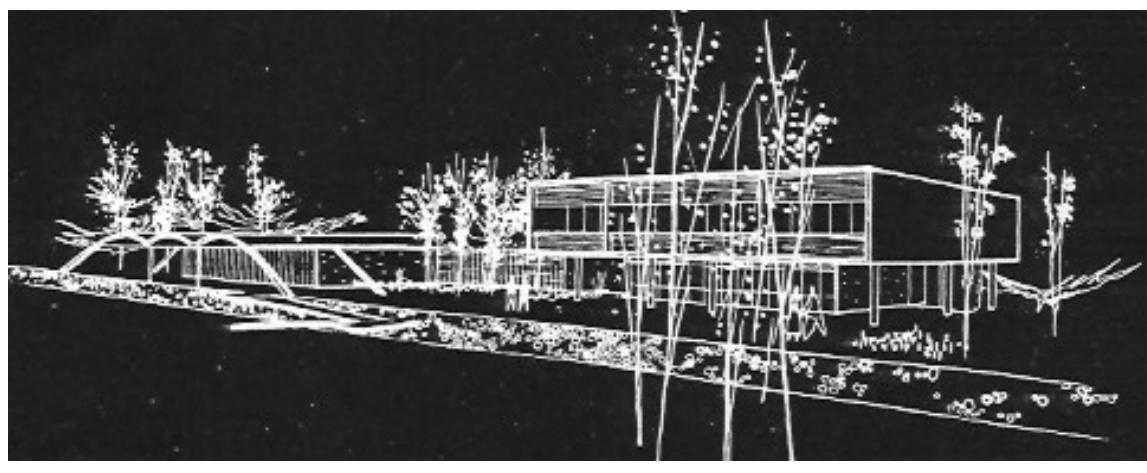

Plano de ocupação de fazenda de propriedade de Joaquim Amaral Amando de Barros encomendado à Zenon Lotufo.

Com a preocupação de atender às várias atividades tanto da família como de seus empregados, o programa previa instalações como a casa-sede, casa do caseiro, casa do administrador, oficinas, capela, casa dos colonos. Programa: Casa-sede: (térreo) Sala de estar / Sala de jantar / Sala de jogos / Cozinha / Copa / Lavanderia; Superior: Dormitórios (6) / Banhos / Sala intima; Casa do Administrador: Sala de convivência / Terraço / Dormitórios (4) / Cozinha / Copa / Área de serviço; Capela: Salão / Altar / Sacristia / WC.

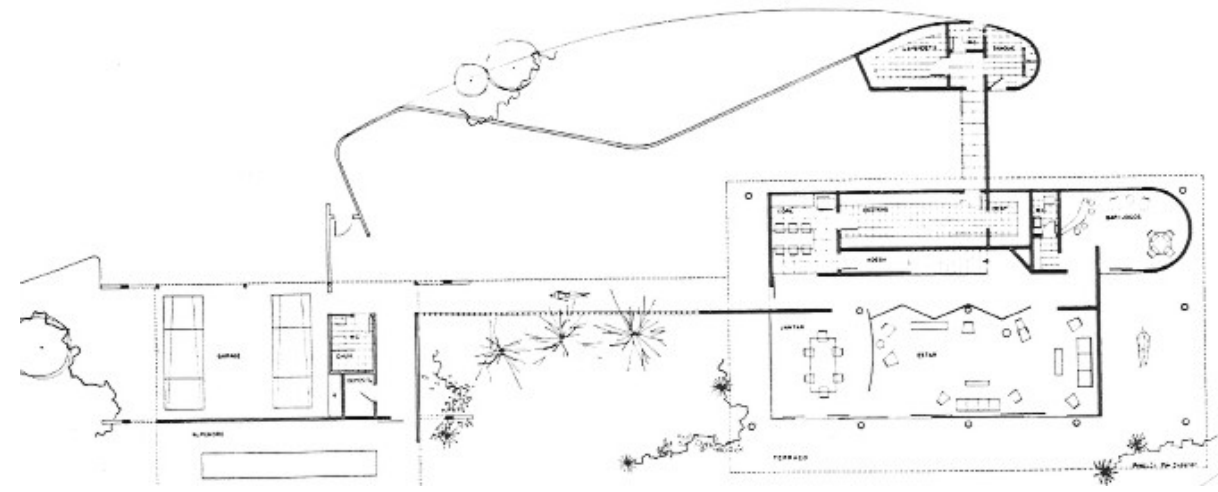

Planta Térreo - Sede

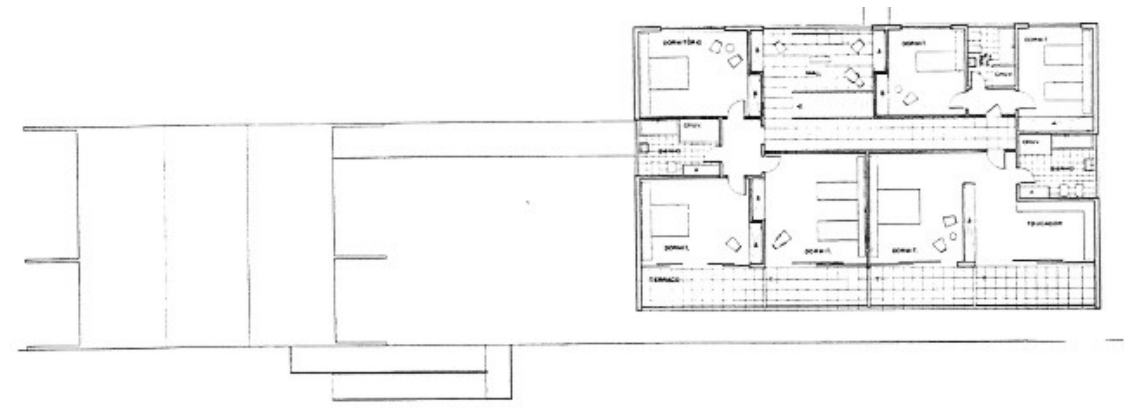

Planta Superior - Sede 


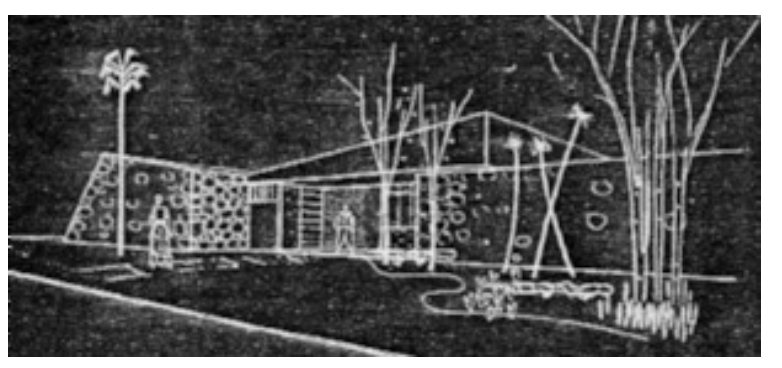

Casa do administrador
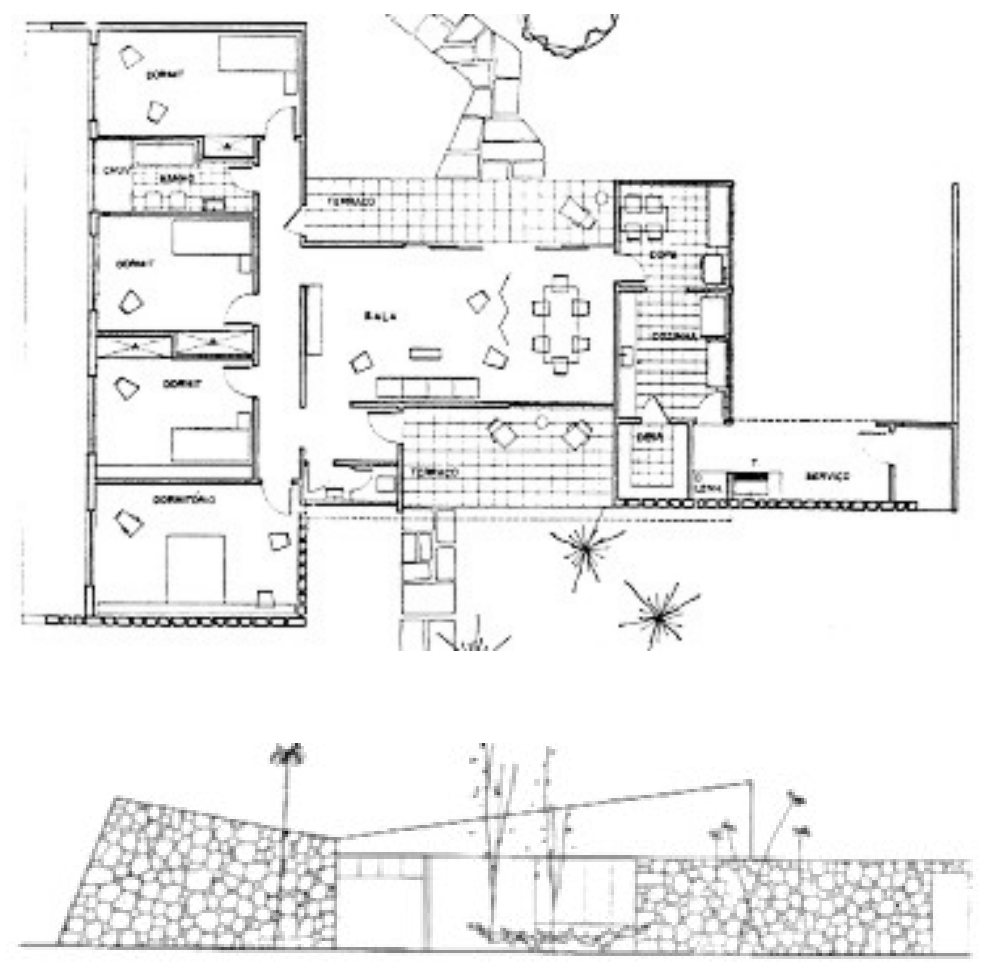

Planta e Elevação - Casa administrador
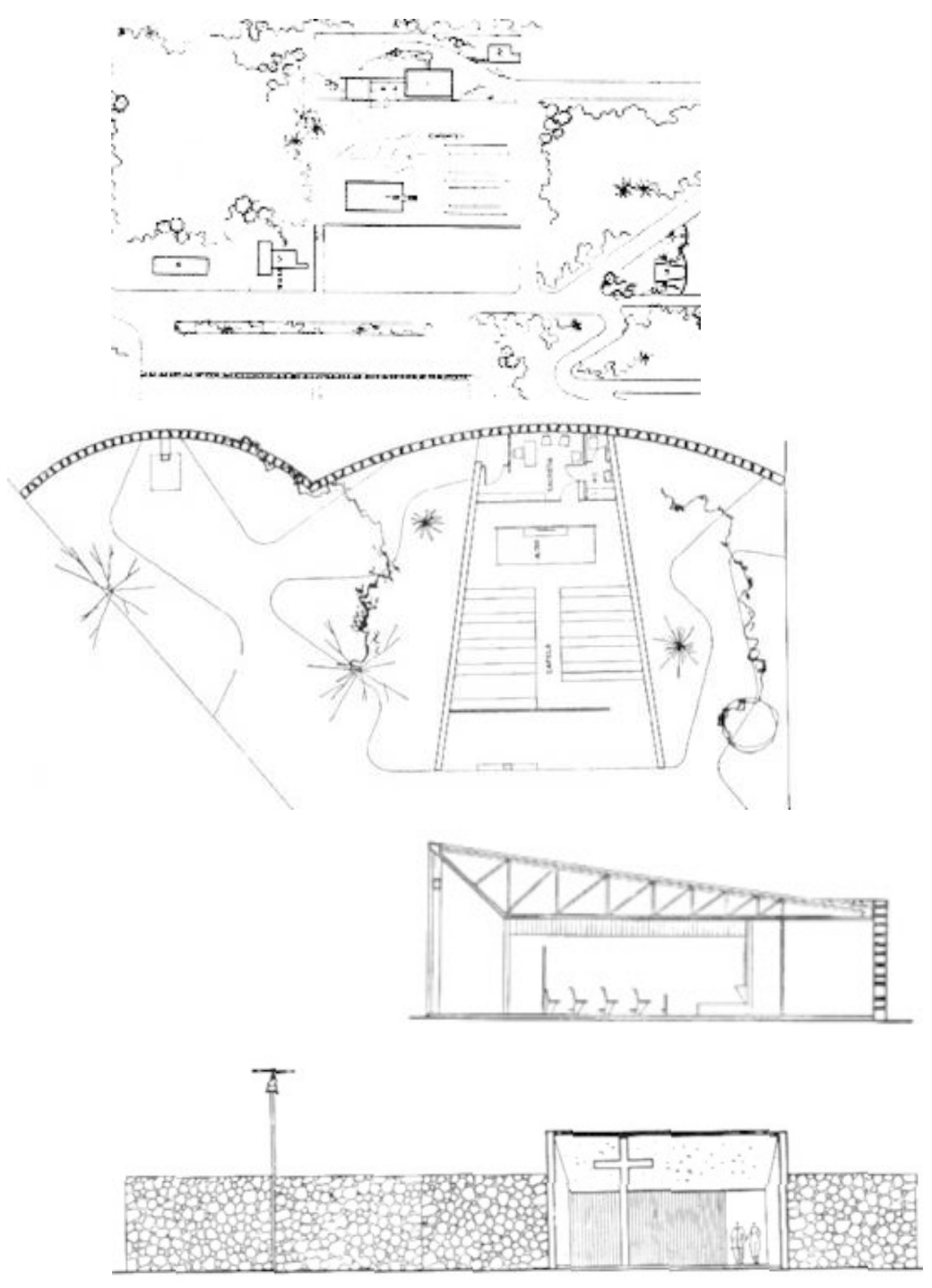

Implantação Geral, Planta, Corte e Elevação - Capela 
Anteprojeto para Residência (São Paulo/SP, 1956)

Projeto: Zenon Lotufo

Fonte: Acrópole 216, out 56, pp- 466.

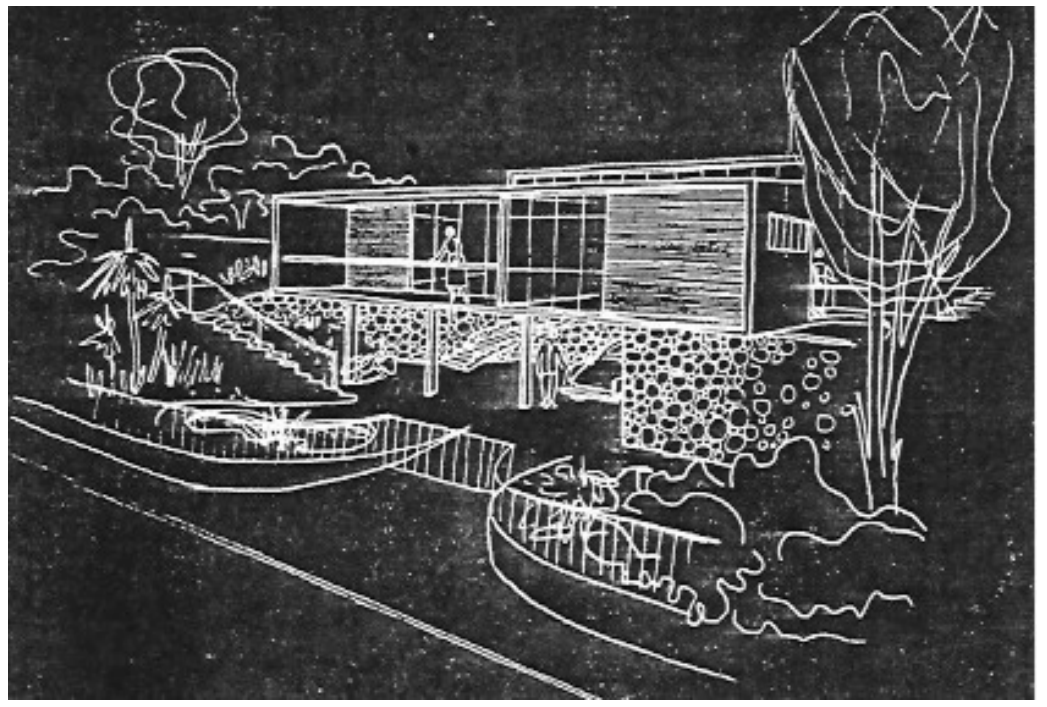

Situado no Jardim Guedala, este anteprojeto de residência procurou se acomodar à topografia do terreno de modo a minimizar os serviços de terraplanagem e aproveita para descortinar a vista da sala de estar e terraço. A funcionalidade das circulações se qualifica com a separação dos acessos aos serviços e demais atividades da casa.

Programa: Térreo: Garagem autos / Lavanderia / Quarto de empregada / Banho / Jardim; Superior: Sala de Estar / Sala de Jantar / Terraço / Copa / Cozinha / Lavabo / Dormitórios (3) / Escritório / Hall
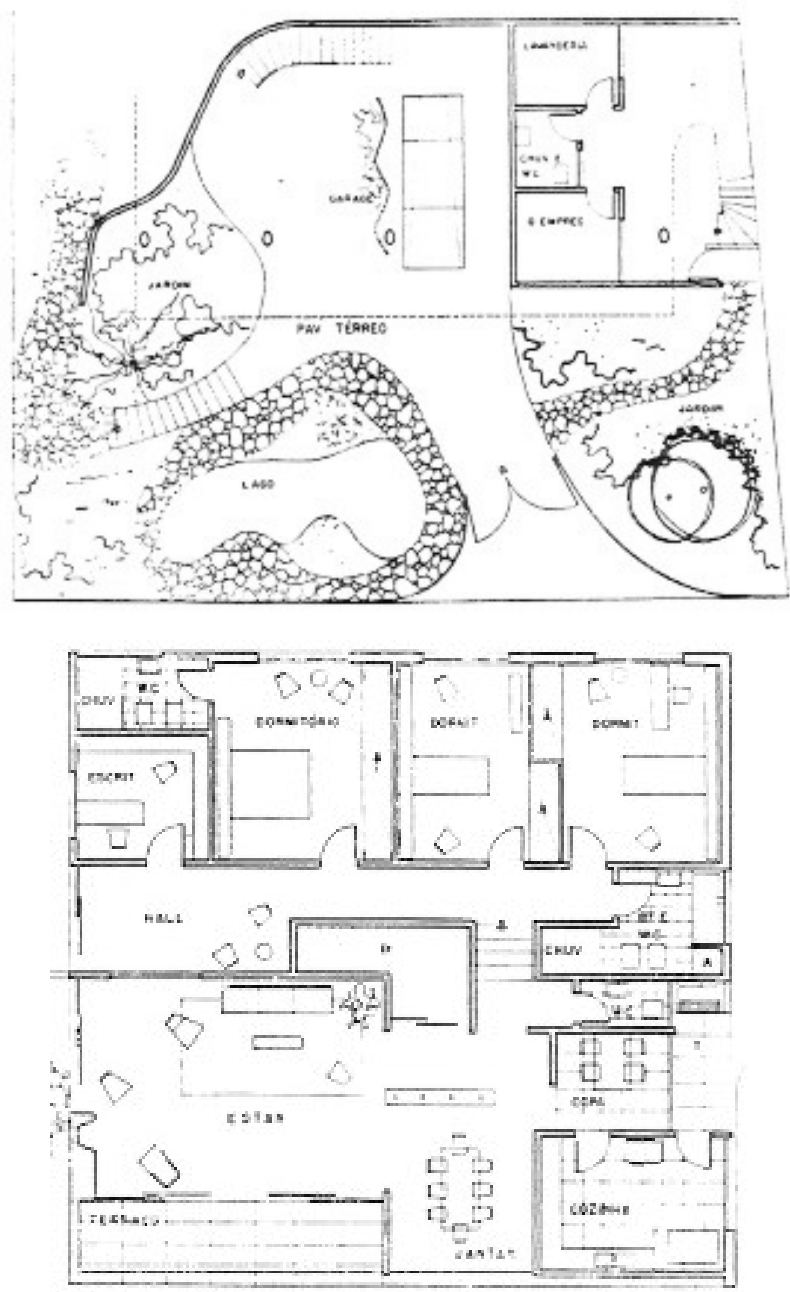

Planta Térreo e Superior 


\section{Estudo para Residência (São Paulo/SP, 1957)}

Projeto: Zenon Lotufo

Fonte: Revista Acrópole 225, jul 57, pp- 327.

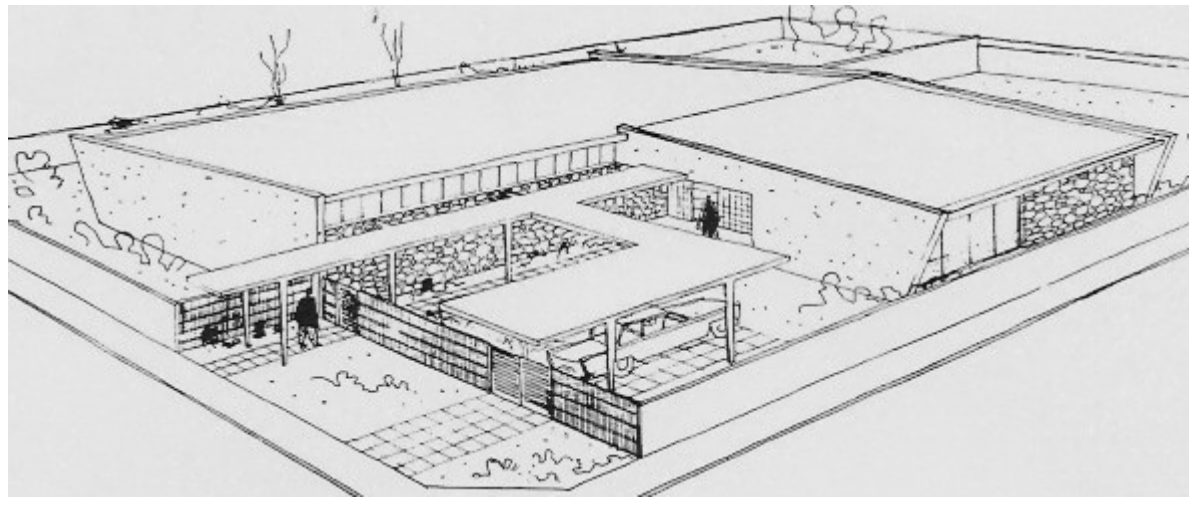

Projeto de residência unifamiliar térrea com volumetria simples e organização programática clara com separação das áreas íntimas (dormitórios) e área social (estar).

Uma marquise horizontal protege e orienta a entrada da casa, desdobrando em um braço que abriga a garagem.

Toda parte hidráulica da casa ficou distribuída ao longo do eixo central (banheiros, cozinha e serviços).

Programa: Residência: Garagem para auto / Hall de entrada / Sala de estar / Sala de jantar / Copa / Cozinha / Pátio / Dormitórios / Banho.

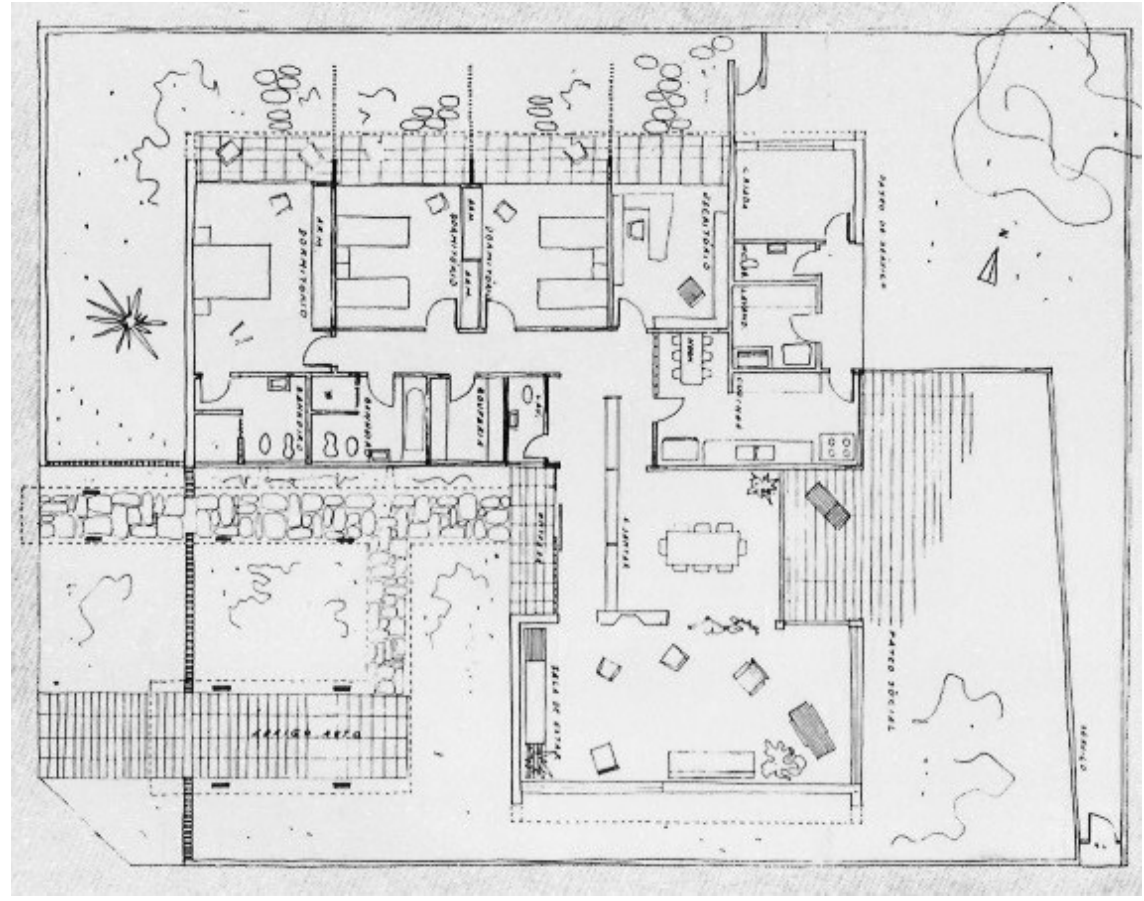

Planta baixa 
Residência Charlotte Brandão (São Paulo/SP, 1958)

Projeto: Zenon Lotufo

Fonte: Acrópole 236, jun 58, pp-399.

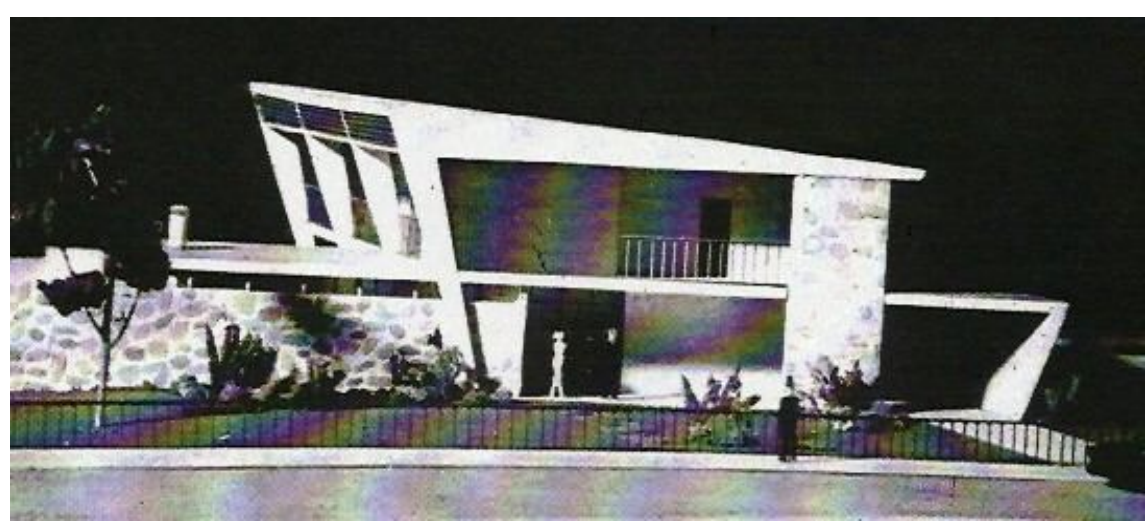

Projeto de residência unifamiliar situada em grande terreno na rua São Sebastião com solução estrutural configurada a partir de pórticos de concreto armado que definem a cobertura.

A garagem para autos ficou localizada no fundo do lote assim como as dependências de empregada.

Contando com uma área de aproximadamente $440 \mathrm{m2}$, o projeto abre toda a parte social da casa (salão com lareira, estar e jantar) para a vista do jardim.

Uma escada circular faz a transição para o piso superior.

Programa: Térreo: Terraço entrada / Salão / Sala de Estar / Sala de Jantar / Terraço / Copa / Cozinha / Área de Serviços

Superior: Dormitórios / Banhos / Escritório / Terraço. 


\section{Residência no Sítio Beira Serra (Botucatu/SP, 1976 - Não Construído)}

Projeto: Zenon Lotufo

Fonte: Reprodução do desenho original em A4, pertencente ao arquivo da família.

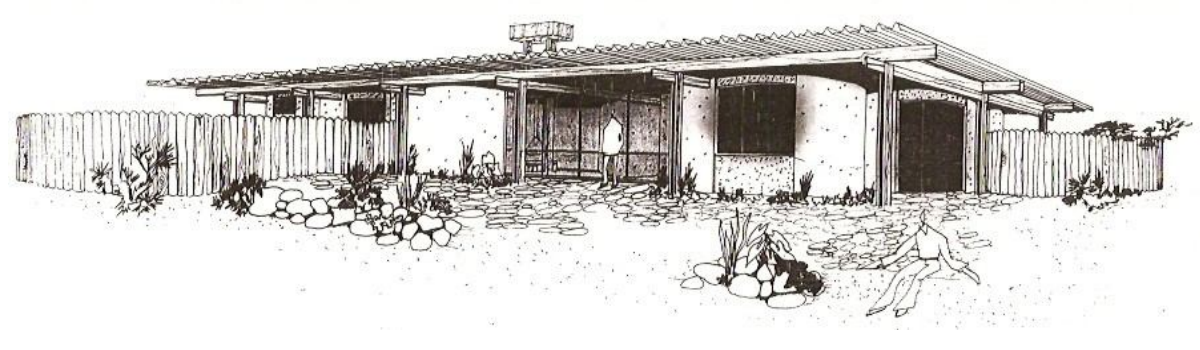

Perspectiva

Talvez o último projeto realizado pelo arquiteto para uma residência em sítio localizado em sua cidade natal, Botucatu. 0 caráter experimental das soluções espaciais chama a atenção pela organização dos ambientes a partir de um conjunto de círculos de tamanhos variados.

A solução estrutural é extremamente simples e modulada com pilares e vigas em madeira e cobertura de telha trapezoidal de fibro-cimento. A modulação regular da estrutura de madeira contrasta com as formas cilíndricas que definem os ambientes da casa e dos muros, o que poderia indicar uma possível mudança no modo de conceber sua arquitetura, apontando para uma nova direção.
Programa: Terraço / Estacionamento para autos / Hall de entrada / Sala de estar / Recanto / Escritório / Lavabo / Sala de refeições / Copa / Cozinha / Pátio de serviços / Dormitórios / Banhos.

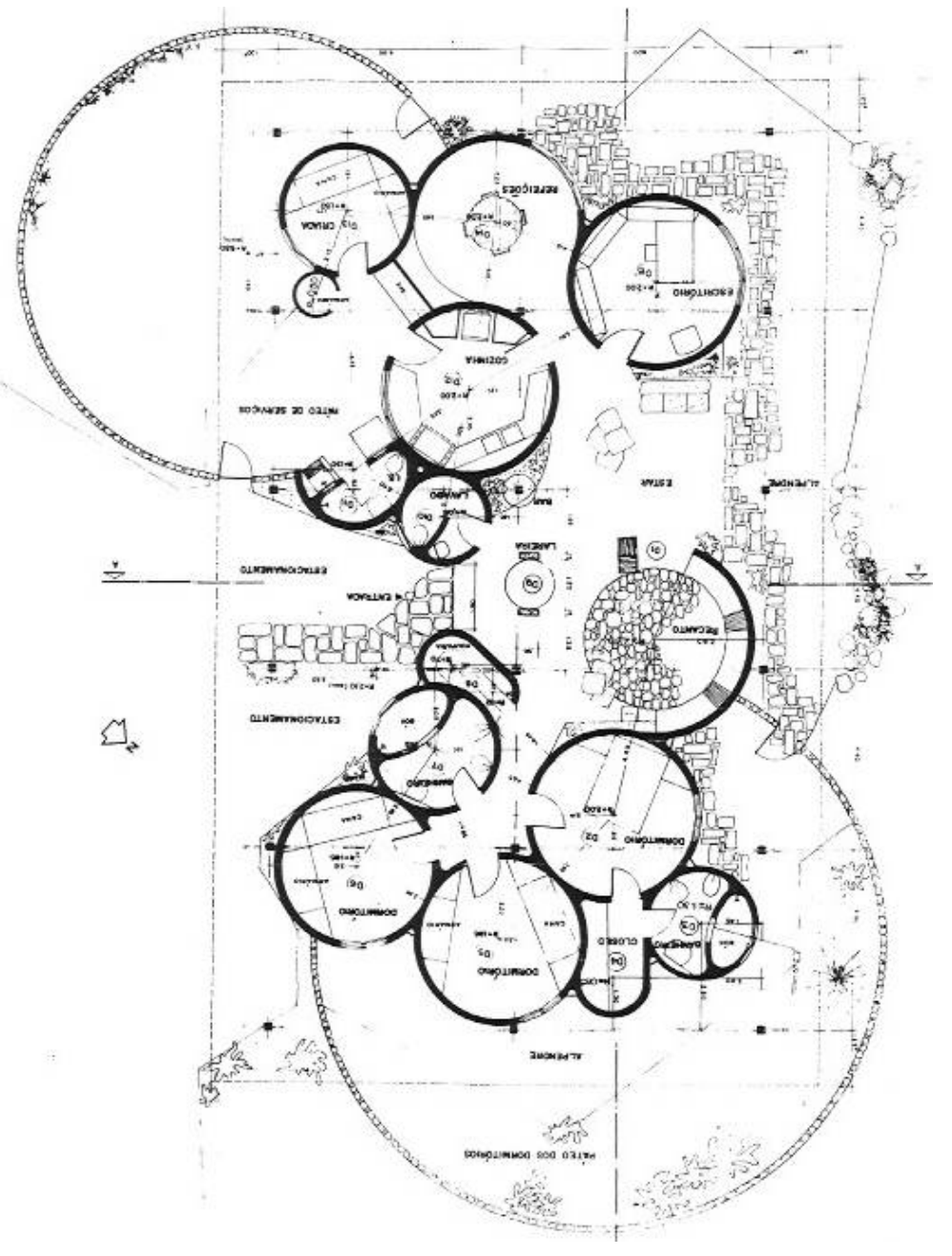


Apêndice 2 - Projetos localizados na Prefeitura Municipal de Botucatu

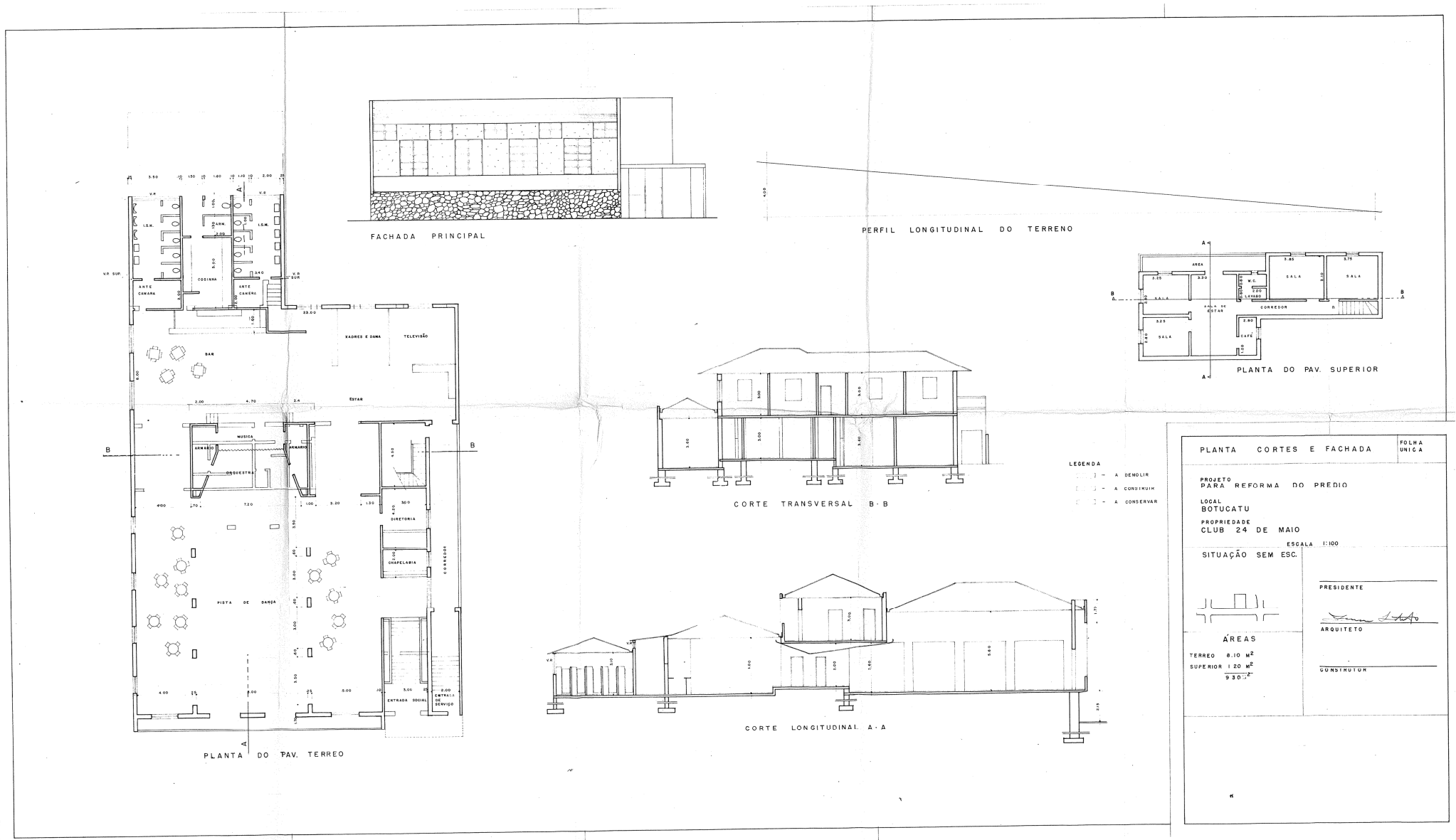

Reforma do Clube 24 de Maio (atual Brasil-Itália) 


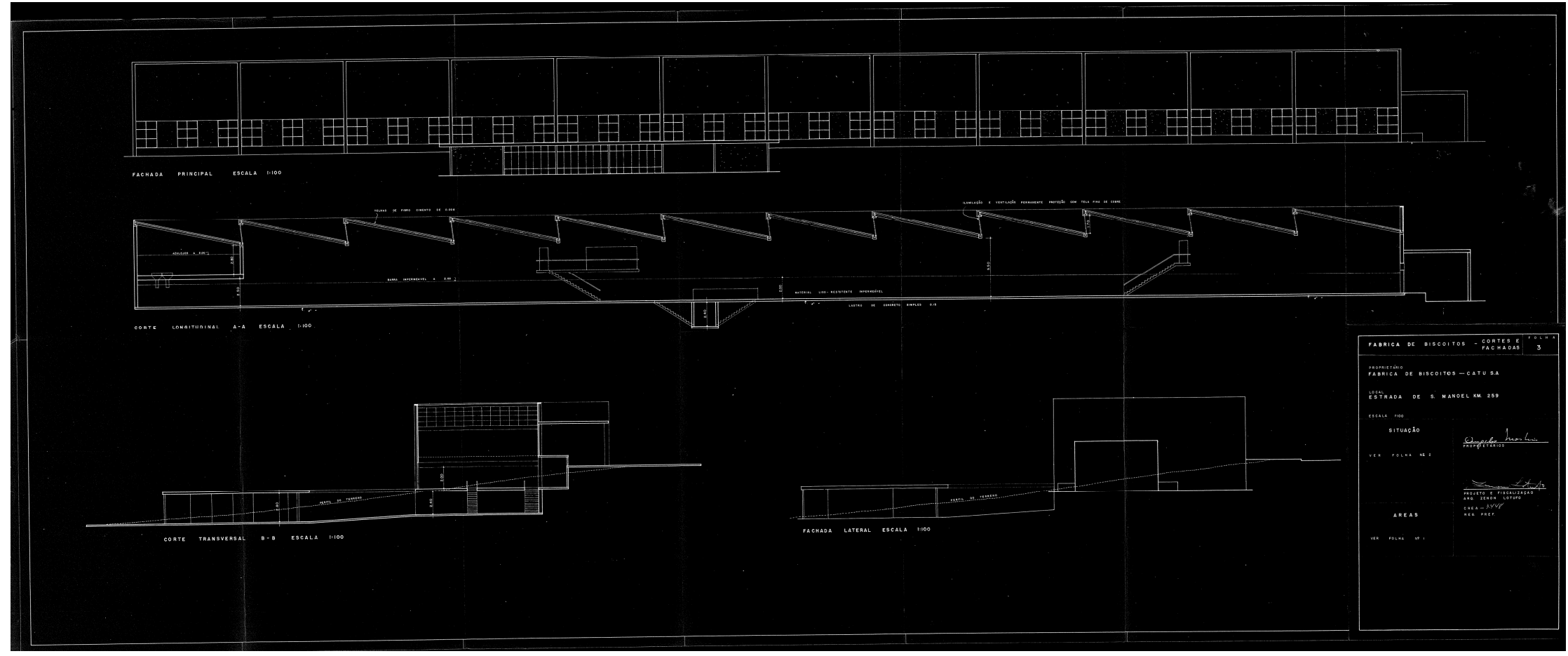

Fábrica de Biscoitos Catu 


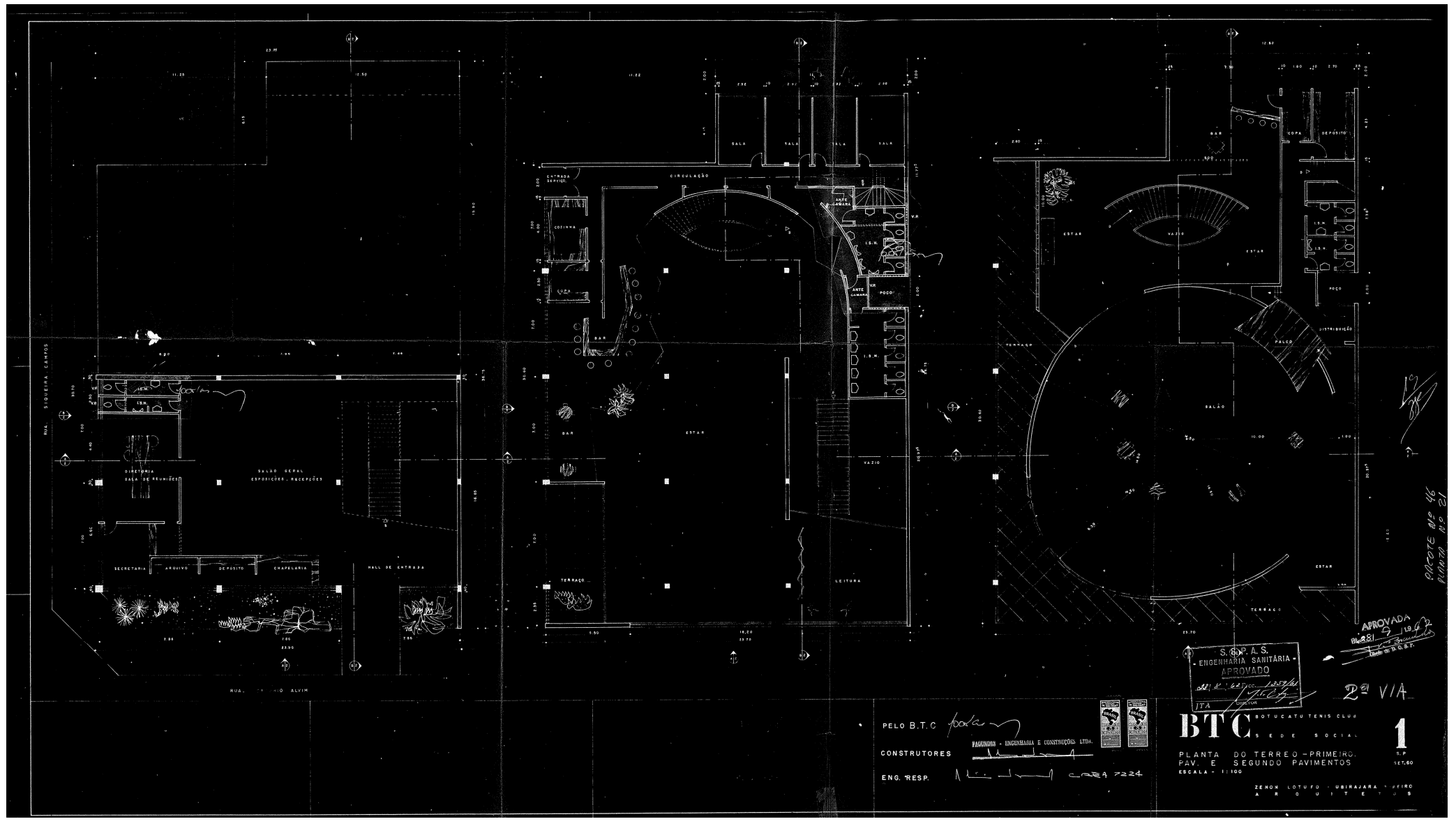

Botucatu Tênis Clube 

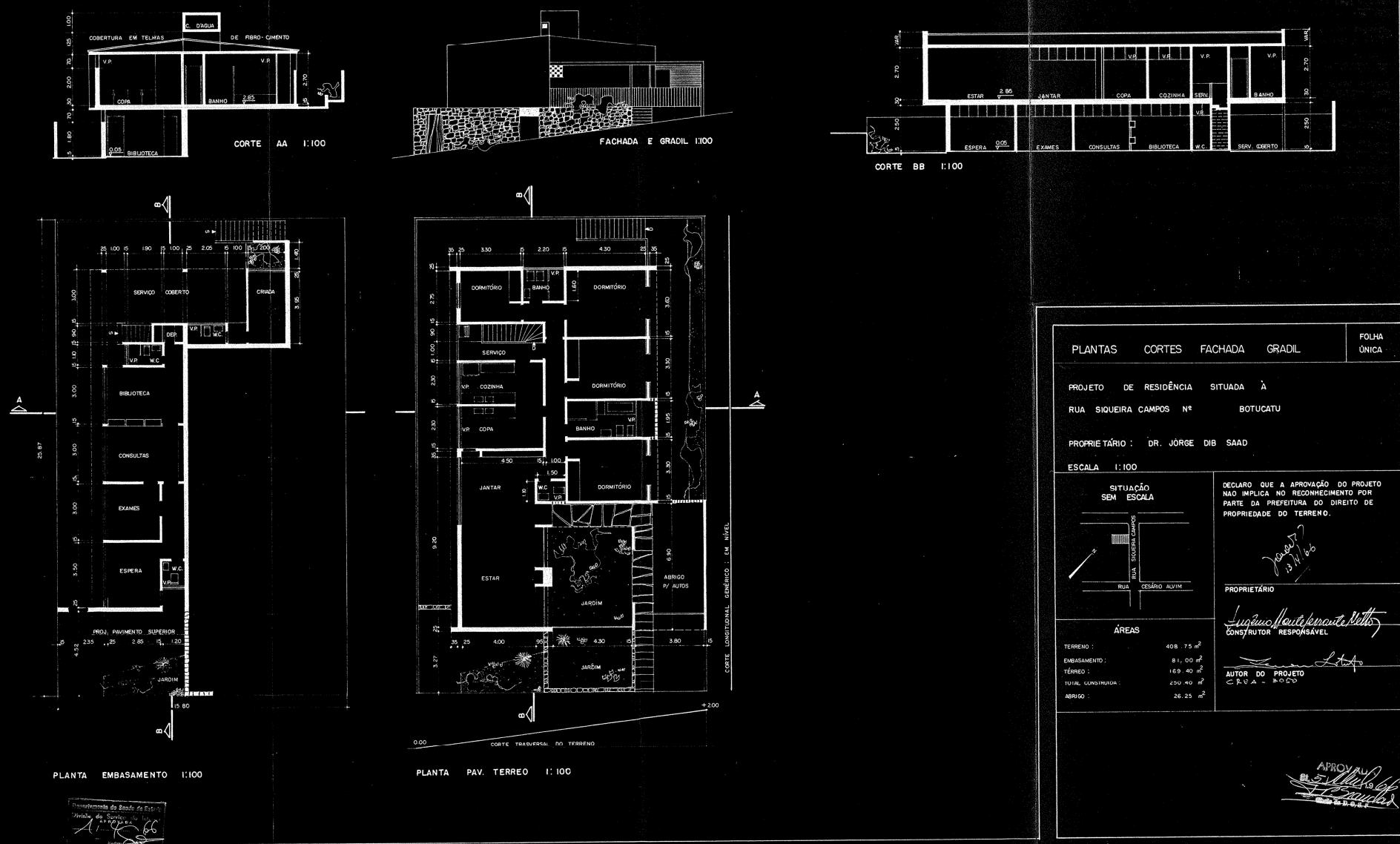

Residência Dr. Jorge Saad 




Edifício comercial José Luiz Amat 
Apêndice 3 - Cronologia das principais obras e projetos

\section{Fase 1 - Anos de formação (31-46)}

1936

Paço M unicipal de Taquaritinga (concurso público, c/ Afonso lervolino) NC 1937

Mercado M unicipal de Sorocaba (concurso público, c/ Afonso lervolino) C 1943

Aquário Municipal de Santos C

(Chefe da Divisão e Diretor de Obras da Prefeitura Municipal de Santos, de 1939 a 45, onde elaborou os Códigos de Obras de Santos e São Vicente).

\section{6}

Plano Diretor da Estância de Campos do Jordão

(Prefeito nomeado da Estância de Campos do Jordão)

Fase 2- "Escola Carioca" (46-58) - Afirmação moderna

1946

Sede do IAB em São Paulo (c/ Abelardo de Souza e Hélio Duarte) C Estância Hidromineral de Santa Bárbara do Rio Pardo (c/ Abelardo de Souza e Hélio Duarte) C 
Instituto de Puericultura da Universidade do Brasil, Rio de Janeiro (c) Abelardo de Souza e Hélio Duarte) NC

Grêmio Recreativo de Ourinhos (c/ Abelardo de Souza e Hélio Duarte) NC Associação Bahiana de Imprensa (ABI), Salvador (c/ Abelardo de Souza/Hélio Duarte) C

Residência Francisco Lotufo Filho, São Paulo C

\section{7}

Cruz Vermelha do Brasil (c/ Abelardo de Souza e Hélio Duarte) NC

Orfanato Amando de Barros, em Botucatu (cl Abelardo de Souza e Hélio Duarte) NC

1948

Edifício D. Hecilda (Rua M ajor Sertório c/ Cesário M otta) São Paulo (com Abelardo de Souza e Hélio Duarte) $\mathbf{C}$

Edifício Pedra Azul (Alameda Jaú) São Paulo (com Abelardo de Souza e Hélio Duarte) C

Cerâmica São Caetano (com Abelardo de Souza e Hélio Duarte) NC

\section{9}

Escola de Enfermagem, Alameda dos Aimorés?

Clube Atlético Paulistano (com G. Warchavchik) PC

Sede da Faculdade de Engenharia Industrial da PUC-SP (São Bernardo do Campo, primeiro lugar concurso, com Plínio Croce) NC

1951
Parque do Ibirapuera em São Paulo (equipe: O. Niemeyer, Hélio Uchoa, Eduardo Kneese de M ello e Carlos Lemos) C

Igreja Presbiteriana (Presidente Prudente) NC

Edificio residencial Arco Íris em Santos?

Residência Honório de Sylos C

1952

Associação Cristã de M oços (rua Nestor Pestana, São Paulo, com Ícaro de C. M ello e Roberto Cerqueira César) C

1953

Igreja Presbiteriana de Bauru NC

Paço e Câmara M unicipal de Bauru PC

Fábrica de Fertilizantes da Petrobrás em Cubatão (com Manoel Machado, Adolfo Morales e Slioma Selter) C

Residência do Arquiteto, M orumbi, São Paulo C

1954

Residência Nilo Andrade Amaral, São Paulo C

Restaurante na Via Anchieta NC

1956

Igreja Presbiteriana, Jandira NC

1957

Paço M unicipal de São Caetano do Sul C

Botucatu Tênis Clube $\mathbf{C}$ 
Museu da Aeronáutica (com Aldo Calvo e Giancarlo Palanti) NC

\section{Fase 3- "Brutalismo e maturidade" (58-85)}

Associação Atlética Banco do Brasil, Porto Alegre (com Ubirajara Ribeiro, vencedor concurso nacional) NC

Departamento de Eletricidade da Escola Politécnica da USP (com

Ubirajara Ribeiro) C

\section{1}

Supermercado no Pacaembu, São Paulo (com Ubirajara Ribeiro) NC

\section{3}

Sindicato dos Trabalhadores da Indústria de Energia Elétrica, São Paulo (com Ubirajara Ribeiro, primeiro lugar concurso nacional) C

\section{5}

Praça de esportes e Estádio Municipal em São Caetano do Sul (com Ubirajara Ribeiro) C

Clube de Campo Lagoa de Cumbica, Guarulhos ?

1967

Edifício para Perícias M édicas - INPS (c/ Vitor Lotufo e Vitor Pini)

Solução arquitetônica e urbanística para o novo viaduto da Avenida Rangel Pestana (sobre as linhas da Estrada de ferro Santos-Jundiaí antigas porteiras do Brás) ?

\section{8}

Grupos escolares em M auá, Santa Fé do Sul, M irante do Paranapanema, Cardoso (todos para o governo do Estado de São Paulo - FECE). C

1969

\section{Colégio Técnico de M ococa (CESP) C}

Escola Técnica Federal de São Paulo (com Vitor Lotufo, Vitor Pini e Cláudio Sganzerla) C

Associação Cristã de M oços na Lapa em São Paulo (com Vitor Lotufo) C Planos de Desenvolvimento Integrado de Limeira, Iracemapolis e Cordeirópolis (Serpla- Serviços de Planejamento) ?

1971

Laboratórios de Engenharia Química do Instituto de Energia Atômica, USP C

Edifício-sede da ORGASTEC - Centro Eletrônico de Processamento de Dados (700 m2) C

\section{2}

Velório do Cemitério do Araçá, São Paulo (com Vitor Lotufo) NC Mercado Distrital do Ipiranga (Prefeitura de São Paulo) C

1973

Estação Rodoviária de Limeira C 
Plano do Conjunto Residencial para a empresa Aracruz-Florestal S.A., município de Aracruz, Espírito Santo ?

\section{Outros projetos sem data}

Ginásio e Colégio - Itajaí, Goiás (C).

Escola de Enfermagem e Hospital em Rio Verde, Goiás (C).

Faculdade de Teologia da Igreja Presbiteriana Independente - Estrada de Cotia ( $\mathrm{km} 2$ ) - conjunto de edifícios destinados a ensino, moradia, culto, esportes e recreação (PC).

NC - Não construído; C - Construído; PC - Parcialmente construído;

? - Não sabe 
Reprodução dos trechos mais significativos da revisão em fichas de papelcartão escritas à mão, da tese "O Espaço psicológico na Arquitetura", feita pelo próprio autor Zenon Lotufo, encontrados no interior de um exemplar pertencente à familia do arquiteto, onde o mesmo cita autores e respectivas obras, traduzidas por ele mesmo:

\section{Las teorias de la Arquitetura}

-"A psicologia da Arquitetura tem por fim descrever e explicar os efeitos psíquicos que a Arquitetura é capaz de evocar por seus meios. E o fim da Arquitetura é a representação de nossos sentimentos e disposições de nossas almas. Os homens não são diferentes, mas semelhantes....

O belo tem caráter de ilusão que é válido para o espaço e para todas as outras representações e sentimentos. "O dever da Estética é buscar e demonstrar a lei psicológica, através da qual se realiza o sentimento do belo".

\section{História crítica da Arte (1ạ. Ed. 1936) - Lionello Venturi (1885-1961)}

- “Alberti demonstra claramente que a origem da arte é psicológica e não histórica e renovam-se cada vez que se cria uma obra de arte". 
-"A imaginação criadora é considerada hoje como atividade espiritual que produz as obras de arte".

-"Por isso, é natural que os críticos tenham se ocupado em estudar os fenômenos psicológicos e da visão, para isso existia a psicologia".

\section{Curso de Estética - Hegel (1770-1831)}

- “O objeto de arte nada é em si, só poderá o ser realmente se atingir nosso ESPÍRITO".

\section{Benedetto Croce (1866-1952)}

- "O belo não tem existência física. 0 caráter estético de um objeto não é uma qualidade sua, mas uma atitude que assumimos diante deste objeto".

\section{Psicologia da Forma (1937) - Paul Guillaume (1878-1962)}

-“A psicologia não tem que criar entidades para explicar os fatos, mas sim descrevê-los e determinar as condições que permitem prevê-los.

0 todo articulado composto por partes secundárias alcança uma percepção global e assim uma existência psicológica real.

“Entendemos por percepção do espaço os aspectos geométricos das coisas: tamanho, direção, distância e localização".

\section{Art et Technique (1956) - Pierre Francastel (1900-1970)}

- “Uma casa será uma espécie de materialização da tensão psíquica do seu ocupante. As condicioantes sociais que orientam o desenvolvimento da técnica".

- "A máquina deshumanizou a vida humana, ela gerou disformidade e horror às cidades, e a vida moderna desenvolveu-se contra a cultura, não é do trabalho que nasce a civilização".

-“O homem não cria as formas, ele as descobre seguindo os principios que o recoloca no plano da criação".

\section{Space, time and Architecture (1941) - Sigfried Giedion (1888-1968)}

-“As influências sociais, econômicas e funcionais desempenham papel vital em todas as atividades humanas, das ciências as artes. No entanto, existem outros fatores importantes - nossos sentimentos e emoções. Comumente descartados como triviais, seus efeitos sobre as ações humanas são enormes".

- “O caráter funcional da indústria e da técnica relegaram as artes (leia-se conteúdo emocional) a um lugar isolado e autônomo, completamente alienada da realidade cotidiana. Como resultado, a vida perdeu unidade $\mathrm{e}$ equilíbrio". 
-“Em particular, não se tornou pacifico que as qualidades estéticas do espaço não sejam limitadas à sua ilimitada vista. A essência do espaço é sua amplitude, que depede de uma infinidade de relações possíveis para com ele, mudando a cada ponto de vista; mas para se compreender a verdade do espaço, o observador deve projetar-se nele e assimilá-lo" .

-"As casa de W right devem ser consideradas como pura expressão artística que profundamente conectadas com aspirações anônimas de sua época".

-"Hoje, o mais urgente problema surge no campo do urbanismo".

\section{Notions d'Esthetique (1925) - Charles Lalo}

"A verdadeira ciência Estética se esforça por fazer a síntese das tendências sociais, políticas e históricas, retendo o que cada escola tem de positivo, desprezando o negativo".

-“Dizemos q uma obra de arte é bela, quando se adapta às funções psíquicas e sociais, ou é capaz de realizar a harmonia ou ainda se purifica ou idealiza a vida coletiva ou individual, enfim quando é capaz de continuar a fase de evolução histórica ou mesmo de reagir contra ela. Ou seja, a estética é um dado essencialmente psicológico".

-“No objeto estético, o sensível é sempre símbolo de um conteúdo espiritual".
-“Grandes revoluções não são individuais, mas sim sociais. Ninguém cria um movimento sozinho, apenas acrescenta sua marca sobre um produto de origem social".

-"A estética é indissoluvelmente objetiva e subjetiva, isto é, as leis da beleza consistem nas relações entre o sujeito e o objeto".

\section{El significado da Arte (1932) - Herbert Read (1893-1968)}

- “O arquiteto grego buscava conseguir a impressão do vazio no espaço, enquanto que o gótico buscava o espaço imaterial da leveza".

\section{Art and Society (1937) - Herbert Read}

-"A elite acumula poder, riqueza e lazer, isto exige símbolos visíveis de seu status, que reflitam sua glória. A arquitetura aparece então em evidência e muitas outras artes seguem seu rastro".

\section{Verso une Architecture Organiche (1945) - Bruno Zevi (1918-2000)}

- "Invés de se aspirar a viver em obras de arte, desejamos viver em casas (material e psicologicamente) confortáveis".

-“Não que Aalto seja um romântico, ao contrário, seu espírito racional dirigia-se aos problemas da estrutura e da distribuição dos ambientes, intimamente vinculados aos aspectos psicológicos da vida". 
-“Cerca de trinta anos depois da Revolução Soviética, conclui-se que este tempo é insuficiente para se construir uma nova cultura. Por outro lado, se neste processo, se houvesse permitido à arte, evoluir organicamente, numa síntese dialética entre imaginação e realidade, tudo poderia estar melhor, porém a realidade foi outra: a imposição de uma concepção intelectual predeterminada do que deveria ser a arte numa comunidade soviética, isto sim foi um erro fatal".

\section{Vision in Motion (1947) - Lazlo Moholy-Nagy (1845-1946)}

-"As condições sociais, as artes, as ciências, o desenvolvimento de uma tecnologia industrial com a pré-fabricação, novos materiais e processos são os fatores determinantes para a realização de um novo desenvolvimento arquitetônico".

\section{Forms, composition et loci d'harmonie (1953) - Andre Lurçat (1894-1970)}

“As necessidades de nossa análise tem nos levado a falar corretamente do espaço seja como elemento constitutivo das formas, seja como base das formulações arquitetônicas onde o vazio é o elemento fundamental". 
- ARRUdA, M. A. do N. M etrópole e Cultura. São Paulo no meio do século do XX. Edusc, Bauru, 2001.

- ARTIGAS, Vilanova. Caminhos da Arquitetura. Cosac Naify, São Paulo, 2004

- BAHNHAM, Reyner. Teoria e projeto na primeira era da máquina. Editora Perspectiva, São Paulo, 2003 (1ª. edição, 1960).

- BASTOS, M. A. Junqueira. Dos anos 50 aos anos 70: como se completou o projeto moderno na arquitetura brasileira. Doutorado FAUUSP, 2004.

- BERGSON, Henri. Cartas, conferências e outros escritos. Coleção Os Pensadores, Edit. Abril, São Paulo, 1984.

- CAVAlCANTI, Lauro. Quando o Brasil era moderno: Guia de Arquitetura 1928-1960. Aeroplano, Rio de Janeiro, 2001.

- Centro de Pesquisa e Estudos Urbanísticos (CEPEU). Plano Diretor de Campos do Jordão: relatório e pranchas de planejamento territorial. FAUUSP, 1960.

- COLQUHOUN, Alan. M odernidade e Tradição Clássica: Ensaios sobre Arquitetura 1980-87. Cosac e Naify, São Paulo, 2004.

- CURTIS, William. Le Corbusier, Ideas and Forms. Phaidon Press, London, 1986 
- DURAND, J-N-P. Precis of the Lectures on Architecture (1802-05). Traduzido em inglês por David Britt. The Getty Research Institute. Los Angeles, 2000.

- FICHER, Silvia. Os arquitetos da Poli. Ensino e profissão em São Paulo. Edusp, São Paulo, 2005.

- GHYKA, Matila. Estética de las Proporciones em la Naturaleza y em las Artes. Ed. Poseidon, Buenos Aires, 1953.

- GIEDION, Sigfried. Espaço, tempo e arquitetura: 0 desenvolvimento de uma nova tradição. Martins Fontes, São Paulo, 2004.

- GUADET, Julien. Elements et Theorie de IÁrchitecture (cours professé á I'École Nationale et Spéciale des Beaux-Arts). Librarie de la construction moderne, Paris, 1909 (3ª. edição original da Biblioteca da Escola Politécnica).

- GUILLAUM E, Paul. Psicologia da forma. Companhia Editora Nacional, São Paulo, 1966 (1ª. Ed. 1937).

- HARRIS, Elizabeth. Le Corbusier: Riscos brasileiros. Editora Nobel, São Paulo, 1987.

- INSTITUTO LINA BO e P.M. BARDI/FUNDAÇÃO VILANOVA ARTIGAS. Vilanova Artigas: arquitetos brasileiros. São Paulo, 1997.

- KOPP, Anatole. Quando o moderno não era um estilo e sim uma causa. Edusp, São Paulo, 1990.
- LE CORBUSIER. Precisões: sobre um estado presente da arquitetura e do urbanismo. Cosac e Naify, São Paulo, 2004.

- LE CORBUSIER. Por uma arquitetura (Vers une Architecture). Editora Perspectiva, São Paulo, 1973. (1ª Edição, 1923).

- LEM OS, C. A.C. Arquitetura Brasileira. Melhoramentos, São Paulo, 1979.

- LOTUFO, Zenon. O Espaço Psicológico na Arquitetura. Tese elaborada para o Concurso de Cátedra, FAUUSP, 1956.

- LOTUFO, Zenon. Arte ou Artifício. Tese apresentada para concurso de cátedra na Escola Politécnica de São Paulo, 1966.

- MAHFUZ, E. C. Ensaio sobre a razão compositiva - uma investigação sobre a natureza das relações entre as partes e 0 todo na composição arquitetônica. Editora U.F.V./ AP Cultural, Belo Horizonte, 1995.

- MINDLIN, Henrique. Arquitetura moderna no Brasil. Editora Aeroplano, Rio de Janeiro, 1999.

- READ, Herbert. As Origens da Forma na Arte. Zahar Editores, Rio de Janeiro, 1967.

- REIS, N. G. (coorden.). Catálogo de exposição "100 anos de Ensino de Arquitetura e Urbanismo em São Paulo", LAP-FAUUSP, 1996.

- ROBERTSON, Howard. Los principios de la Composition Arquitectonica. Editorial Victor Leru, Buenos Aires, 1955. 
- SAARINEN, Eliel. Search for Form: a fundamental approach to art. Reinhold Pub., New York, 1948.

- SANTOS, M. C. L. Escola Politécnica (1894-1984). Edusp, São Paulo, 1985.

- SEGAWA, Hugo. Arquiteturas no Brasil 1900-1990. Edusp, São Paulo, 2002.

- SCOTT, Geoffrey. The Architecture of Humanism. London Company LTD, 1935 (1ạ. Ed. 1914).

- SOUZA, Abelardo Riedy de. Arquitetura no Brasil: Depoimentos. Diadorim/EDUSP, São Paulo,1978.

- SUM M ERSON, John. El lenguaje clasico de la arquitectura - De Alberti a Le Corbusier. Edit. Gustavo Gili, Barcelona, 1984.

- UNDERW OOD, David. Oscar Niemeyer e o modernismo de formas livres no Brasil. Cosac \& Naify, São Paulo, 2002.

- XAVIER, Alberto (org.). Depoimento de uma geração: arquitetura moderna brasileira. Cosac Naify, São Paulo, 2003.

- WITTKOWER, Rudolf. La arquitectura em la edad del Humanismo. Editorial Nueva Vision, Buenos Aires, 1958 (1ạ. Ed. 1949).

\section{Teses e dissertações}

- COnstantino, R. A. A obra de Abelardo de Souza. Dissertação de Mestrado, FAUUSP, 2004.
- ALBUQUERQUE, R. A. Uma Escola de Arquitetura - FAUUSP: edifícios e ensino. Dissertação de M estrado, FAUUSP, São Paulo, 2004.

- BASTOS, M. A. J. Dos anos 50 aos anos 70: Como se completou o projeto moderno na arquitetura brasileira. Tese de Doutorado, FAUUSP, São Paulo, 2004.

- CORONA, Eduardo. Princípios fundamentais de composição na Arquitetura brasileira. Tese para Catedra em "Teoria da Arquitetura", FAUUSP, 1957.

- FERRAZ, Á. R. F. Marcas do Moderno na Arquitetura de Bauru. Dissertação de M estrado, EESC-USP, São Carlos, 2003.

- PONTES, A.P.G.Diálogos silenciosos: arquitetura moderna brasileira e tradição clássica. Dissertação de mestrado, PUC-RJ, 2004.

- SANTOS, L. C. Arquitetura Paulista em torno de 1930-40. M estrado. FAUUSP, São Paulo, 1985.

\section{Revistas e periódicos}

Acrópole: n. 03, 97, 99, 100, 103, 104, 106, 108, 114, 117, 131, 132, 137 , $155,171,180,184,186,195,209,216,223,225,226,228,236,264,269$, 298, 316, 327, 363.

AB Arquitetura Brasileira: n. 8.

AD Arquitetura e Decoração: n. 2, 6, 14.

Arquitetura e Engenharia: n. 16. 
AU Arquitetura e Urbanismo n. 76.

Habitat: n. 20, 39.

Módulo: n. 4, 19.

Revista Politécnica n. 119, 120, 121, 122 e 125.

\section{Artigos e Mídias eletrônicas}

- LOTUfO, Zenon. Planejamento e Lazer. Publicado no Jornal de Botucatu, em 14 de fevereiro de 1981.

- LOTUfO, Zenon. Arquitetura - A Casa. Publicado no Jornal de Botucatu,em 13 de junho de 1981.

- LOTUFO, Zenon. M unicípios Pobres. Publicado no Jornal de Botucatu, em 22 de setembro de 1982.

- NIEM EYER, Oscar. Conversa de arquiteto. Publicado no jornal Folha de São Paulo, em 16 de julho de 2006, caderno A, p. 3.

- MARTINS, C. A.F. "Construir uma arquitetura, construir um país" em Da Antropofagia à Brasília 1920-1950. Catálogo de exposição MAB/FAAP, Cosac Naify, São Paulo, 2002, p. 373-383.

- FOUCALT, M ichel. 0 que é a crítica? (Qu'est-ce que la critique?)Bulletin de la Société française de philosophie, Vol. 82, no 2, pp. 35 - 63, avr/juin 1990 (Conferência proferida em 27 de maio de 1978). Tradução de Gabriela Lafetá Borges e revisão de
Wanderson Flor do Nascimento. Em

বttp://www.unb.br/fe/tef/filoesco/foucault/critique.html>

- SANTOS, Roberto E. . Disciplina e Legitimação do Conhecimento de artigo eletrônico em

〈ttp:// www.arquitetura.ufmg.br/ia/disciplinalegitimidade.html>

- FUÃO, Fernando F. Brutalismo, a última trincheira do movimento moderno. em

বhttp://www.romanoguerra.com.br/arquitextos/arq000/esp036.a $\mathrm{sp}>$

- বhttp://www.vitruvius.com.br >

- http://www.usp.br/fau/fau/histórico

\section{Índices}

- Índice de arquitetura brasileira, 1950/70. Pesquisa e coordenação: Eunice R. Ribeiro Costa e Maria Stella de Castilho, Universidade de São Paulo, Faculdade de Arquitetura e Urbanismo, 1974.

\section{Lista de figuras}

As respectivas informações das reproduções iconográficas estão relacionadas nas páginas onde as mesmas aparecem, contendo número da imagem e fontes, situando-se ou imediatamente abaixo da figura, ou abaixo do título do projeto mencionado. 